University of South Carolina

Scholar Commons

$11-1998$

\title{
A Historic Context Statement for a World War II Era Black Officers' Club at Fort Leonard Wood, Missouri
}

Steven D. Smith

University of South Carolina - Columbia, smiths@mailbox.sc.edu

Follow this and additional works at: https://scholarcommons.sc.edu/archanth_books

Part of the Anthropology Commons

\section{Recommended Citation}

Smith, Steven D., "A Historic Context Statement for a World War II Era Black Officers' Club at Fort Leonard Wood, Missouri" (1998). Research Manuscript Series. 210.

https://scholarcommons.sc.edu/archanth_books/210

This Book is brought to you by the Archaeology and Anthropology, South Carolina Institute of at Scholar Commons. It has been accepted for inclusion in Research Manuscript Series by an authorized administrator of Scholar Commons. For more information, please contact digres@mailbox.sc.edu. 


\section{A Historic Context Statement for a World War II Era Black Officers' Club at Fort Leonard Wood, Missouri}

\section{Description}

This report provides a historic context statement for Building 2101, a WWII period Black Officers' Club located at Fort Leonard Wood, Missouri, that is still in active use. The best historical evidence indicates that the building, a standard A-12 temporary classroom building, was designed as the club for black officers stationed at Fort Leonard Wood sometime between June 1942 and January 1943. Later in 1943, it was expanded with an addition. The building was built as part of Fort Leonard Wood's initial construction and used as a Personnel Adjutant's Office for the Engineer Replacement Training Center, 7th Training Group (Colored), until reassigned for the exclusive use of black officers who were denied the use of Fort Leonard Wood's main officers' club. After the addition's construction, a mural was painted above the fireplace located at the gable end of this addition. The artist of the mural was Staff Sergeant Samuel Albert Countee, a professional artist and a rising talent in the world of American black art. In 1945, POWs constructed a stone chimney on the exterior of the building and also constructed elaborate stone walkways and walls for erosion control around the building. A history of the Engineer Replacement Training Center, its black enlisted personnel, and officers, is provided to better understand the building's historical context and value. A separate chapter discusses Samuel Countee and his mural. An appendix discusses the POW stonework at Fort Leonard Wood. Building 2101 was determined eligible for listing on the National Register of Historic Places in August 1998 by the Missouri State Historic Preservation Office, and stands as a symbol of the African American military experience during WWII--specifically the struggle of black officers of WWII to maintain a leadership presence in an army that was conflicted by their very presence. The black officer in WWII was a dilemma to the U.S. Army--a dilemma to policy makers, to both those who opposed and to those who supported their contribution, and to their race. The question of what to do with the black officer ultimately could not be answered during the war, because the answer was full integration, thereby making the black officer transparent in the officer corps. Until that time came, the black officer stood to remind the nation that a contributing segment of its population was being set aside from full membership. Although seemingly unpretentious in appearance, the building stands as a reminder of a period when the nation was vigorously challenging the continued existence of two racially intolerant governments (Nazi Germany and Imperial Japan), but was at the same time struggling with inequality at home. The building also contains a National Register eligible rare surviving example of WWII soldier art by an established black artist, and is surrounded by rare German POW stonework.

\section{Keywords}

Fort Leonard Wood, Missouri, World War II, Officers' clubs, African American, Military, Army, POWs, Stonework, Historic Buildings

\section{Disciplines}

Anthropology

\section{Publisher}

The South Carolina Institute of Archeology and Anthropology--University of South Carolina

\section{Comments}

In USC online Library catalog at: http://www.sc.edu/library/ 


\section{1 ' \\ 101 I}

U.S. Army Corps of Engineers

Construction Engineering

Research Laboratories

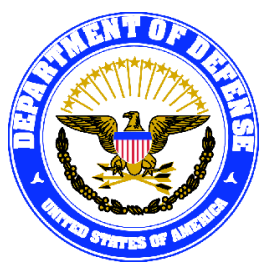

U.S. Department of Defense Legacy Resource Management Program

\section{A HISTORIC CONTEXT STATEMENT FOR A WORLD WAR II ERA BLACK OFFICERS' CLUB AT FORT LEONARD WOOD, MISSOURI}

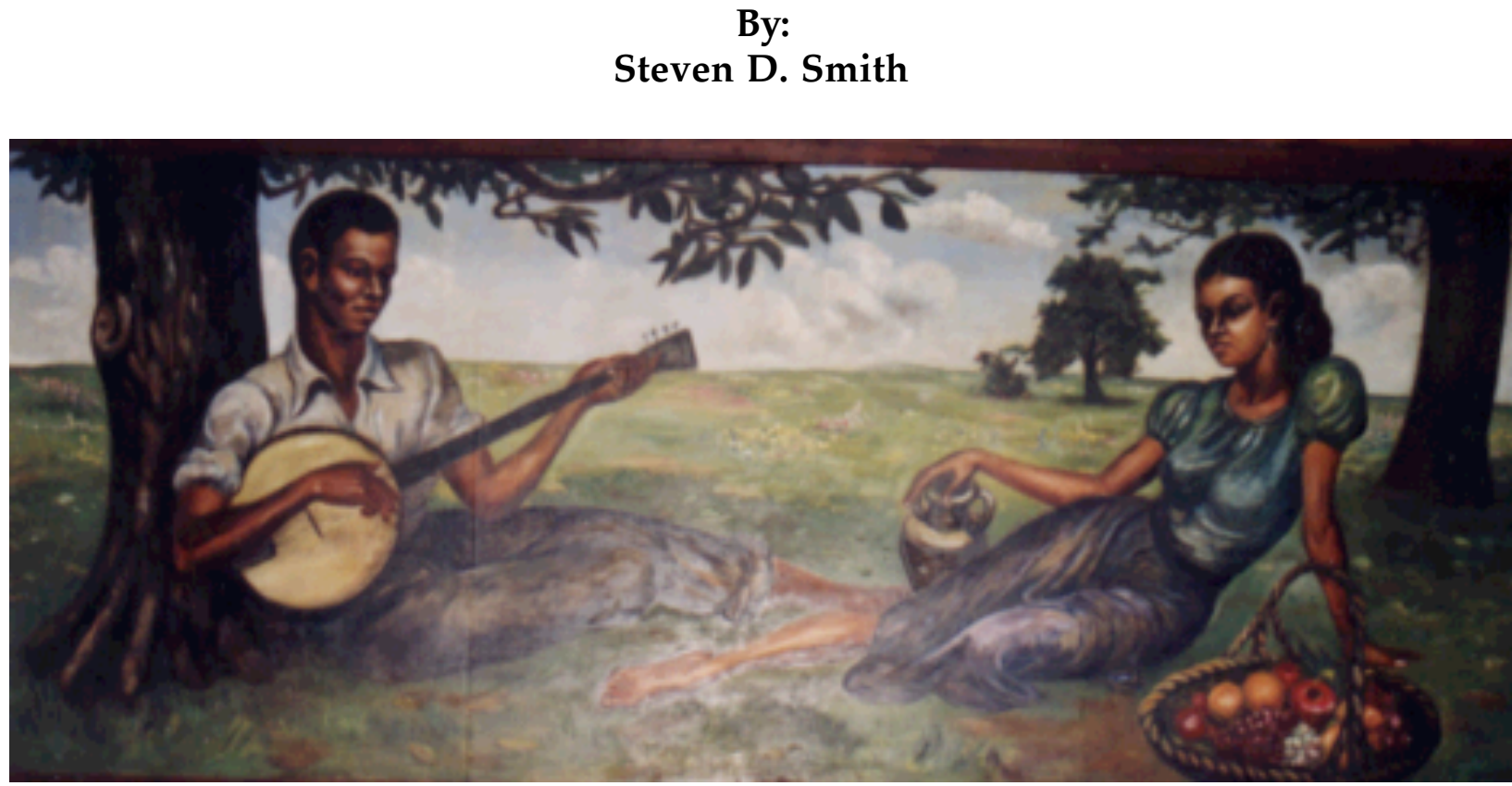

U.S. Army Construction Engineering Research Laboratories

Cultural Resources Research Center

Technical Report 99/02

South Carolina Institute of Archaeology and Anthropology

Research Manuscript Series 227

Funding Provided by:

Legacy Resource Management Program

Department of Defense

November 1998 



\title{
A HISTORIC CONTEXT STATEMENT FOR A WORLD WAR II ERA BLACK OFFICERS' CLUB AT FORT LEONARD WOOD, MISSOURI
}

\author{
Prepared By: \\ Steven D. Smith \\ South Carolina Institute of Archaeology and Anthropology
}

With An Appendix:
GERMAN POW STONEWORK AT FORT LEONARD WOOD, MISSOURI
by Geoffrey C. Burt, Suzanna Walaszek, and
Richard Edging
USACERL

U. S. Army Construction Engineering Research Laboratories Cultural Resources Research Center

Technical Report 99/02

South Carolina Institute of Archaeology and Anthropology

Research Manuscript Series 227

Funding Provided by:

Legacy Resource Management Program

Department of Defense

November 1998 
Cover Art: The mural at the Black Officers' Club, Fort Leonard Wood, by Samuel Albert Countee, c. 1943-45. 


\section{UNITED STATES DEPARTMENT OF DEFENSE LEGACY RESOURCE MANAGEMENT PROGRAM}

The Legacy Resource Management Program was established by the Congress of the United States in 1991 to provide the Department of Defense with an opportunity to enhance the management and stewardship of resources on over 25 million acres of land under DoD jurisdiction.

Legacy allows DoD to determine how to better integrate the conservation of irreplaceable biological, cultural, and geophysical resources with the dynamic requirements of military missions. To achieve this goal, DoD gives high priority to inventorying, protecting, and restoring biological, cultural, and geophysical resources in a comprehensive, cost-effective manner, in partnership with Federal, State, and local agencies, and private stakeholders.

Legacy activities help to ensure that DoD personnel better understand the need for protection and conservation of natural and cultural resources, and that the management of these resources will be fully integrated with, and support, DoD mission activities and the public interest. Through the combined efforts of the DoD components, Legacy seeks to achieve its legislative purposes with cooperation, industry, and creativity, to make the DoD the Federal environmental leader. 


\section{PREFACE}

The Cultural Resources Research Center at the U.S. Army Construction Engineering Research Laboratories (USACERL) in Champaign, Illinois, has been involved for over a decade in all facets of cultural resource management and historic preservation issues related to military installations and training lands. USACERL's cultural resource program consists of three basic areas: (1) prehistoric and historic archeological resources, (2) Native American issues, and (3) historic structures and landscapes. The basic tasks of these diverse areas are to evaluate and manage significant cultural properties in compliance with current historic preservation legislation in order to avoid impeding or adversely affecting the military mission.

One of the most useful and cost-effective tools for evaluating cultural resources is the nationwide "theme and context" study. A historic context is defined as an organizational format that groups historic properties that share similarities of time, theme, and/or geography. By grouping related cultural resources within a broader historic context, significance evaluations and nominations to the National Register of Historic Places (NRHP) can be conducted much more readily since basic reference material is already available, thereby providing significant cost savings for the Department of Defense. The USACERL Cultural Resources Research Center has conducted a number of such "theme and context" studies. These include thematic overviews on World War II temporary structures, Department of Defense aircraft hangers and cold war facilities, Central and Northern Plains archeological overviews, and the African American military experience.

A recent historic context study, A Historic Context for the African American Military Experience, USACERL CRRC 98/87, provided the baseline for evaluating buildings and sites significant to African American military history for nomination to the National Register of Historic Places. The present study represents the first effort at evaluating a World War II period building at Fort Leonard Wood, Missouri, that was used as a Black Officers' Club for the Engineer Replacement Training Center (ERTC).

The Cultural Resources Research Center is pleased to have had the continued support of the Legacy Resource Management Program for this project as well as the collaboration of scholars from the South Carolina Institute of Archaeology and Anthropology, University of South Carolina, in conducting the historical research. It is our hope that the information contained in this report will enhance our understanding of the African American military experience during World War II.

Richard Edging, Ph.D.

Suzanna Walaszek

Principal Investigators 


\section{FOREWORD}

This study was conducted for the Legacy Resource Management Program under the auspices of the Office of the Deputy Undersecretary of Defense for Environmental Security, Reimbursable order No. N57. The technical monitor was Ms. Jackie Howard, ODUSD (ES).

The work was performed under the direction of the Cultural Resources Research Center, Planning and Mission Impact Division (LL-P) of the Land Management Laboratory (LL), U.S. Army Construction Engineering Research Laboratories (USACERL). The USACERL co-principal investigators were Dr. Richard Edging and Suzanna Walaszek. The research was conducted under the direction of Steven D. Smith, South Carolina Institute of Archaeology and Anthropology, University of South Carolina. Dr. Harold E. Balbach is Chief, CECER-LL-P; Dr. John T. Bandy is Operations Chief, CECER-LL. The USACERL editor was Gloria J. Wienke, Technical Information Team. Colonel James A. Walter is Commander and Dr. Michael J. O'Connor is Director of USACERL.

This document is a Legacy Program work product and does not suggest or reflect the policy, programs, or doctrine of the Department of the Army, Department of Defense, or United States Government. 


\section{SCIAA MANAGEMENT SUMMARY}

This report provides a historic context statement for Building 2101, a WWII period Black Officers' Club located at Fort Leonard Wood, Missouri, that is still in active use. The best historical evidence indicates that the building, a standard A-12 temporary classroom building, was designed as the club for black officers stationed at Fort Leonard Wood sometime between June 1942 and January 1943. Later in 1943, it was expanded with an addition. The building was built as part of Fort Leonard Wood's initial construction and used as a Personnel Adjutant's Office for the Engineer Replacement Training Center, 7th Training Group (Colored), until reassigned for the exclusive use of black officers who were denied the use of Fort Leonard Wood's main officers' club. After the addition's construction, a mural was painted above the fireplace located at the gable end of this addition. The artist of the mural was Staff Sergeant Samuel Albert Countee, a professional artist and a rising talent in the world of American black art. In 1945, POWs constructed a stone chimney on the exterior of the building and also constructed elaborate stone walkways and walls for erosion control around the building. A history of the Engineer Replacement Training Center, its black enlisted personnel, and officers, is provided to better understand the building's historical context and value. A separate chapter discusses Samuel Countee and his mural. An appendix discusses the POW stonework at Fort Leonard Wood.

Building 2101 was determined eligible for listing on the National Register of Historic Places in August 1998 by the Missouri State Historic Preservation Office, and stands as a symbol of the African American military experience during WWII--specifically the struggle of black officers of WWII to maintain a leadership presence in an army that was conflicted by their very presence. The black officer in WWII was a dilemma to the U.S. Army--a dilemma to policy makers, to both those who opposed and to those who supported their contribution, and to their race. The question of what to do with the black officer ultimately could not be answered during the war, because the answer was full integration, thereby making the black officer transparent in the officer corps. Until that time came, the black officer stood to remind the nation that a contributing segment of its population was being set aside from full membership. Although seemingly unpretentious in appearance, the building stands as a reminder of a period when the nation was vigorously challenging the continued existence of two racially intolerant governments (Nazi Germany and Imperial Japan), but was at the same time struggling with inequality at home. The building also contains a National Register eligible rare surviving example of WWII soldier art by an established black artist, and is surrounded by rare German POW stonework.

Steven D. Smith

SCIAA Principal Investigator 


\section{TABLE OF CONTENTS}

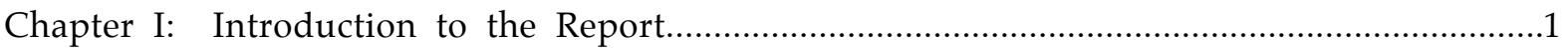

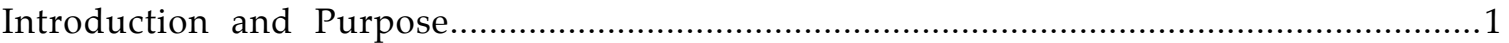

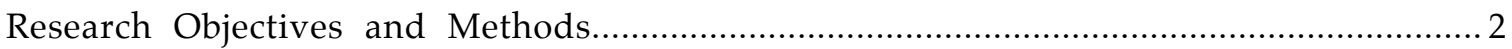

Previous Research and Preservation Regarding Building 2101.............................................. 4

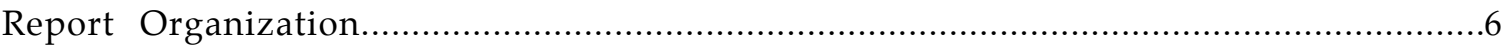

Chapter II: African Americans and the Engineer Replacement Training Center,

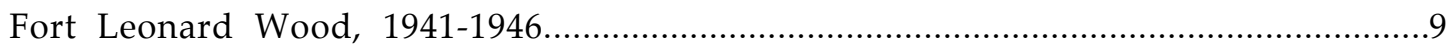

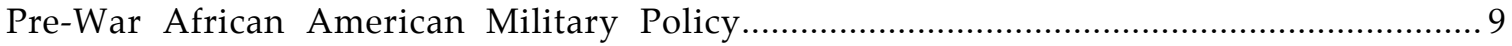

Mobilization and the Engineer Replacement Training Centers.............................................. 16

The Engineer Replacement Training Center (ASFTC) at Fort Leonard Wood............................18

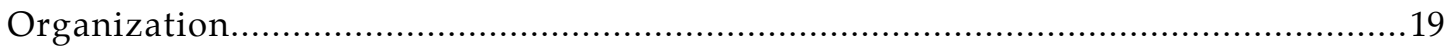

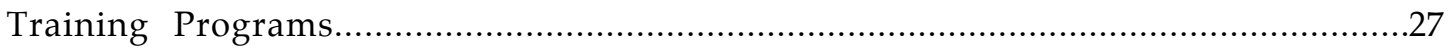

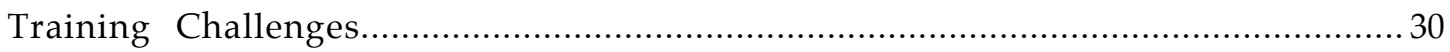

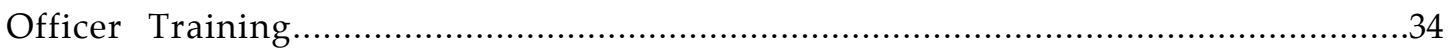

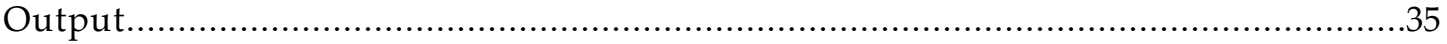

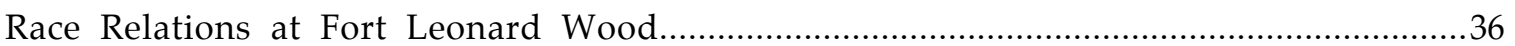

Black Units in the Army Ground Forces at Fort Leonard Wood................................................. 43

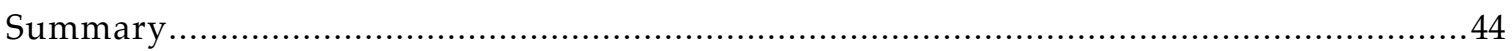

Chapter III: Black Officers at Fort Leonard Wood.................................................................47

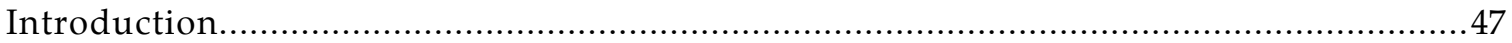

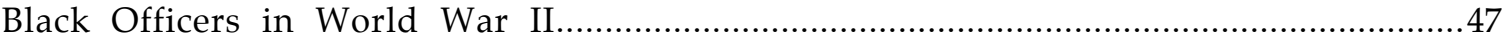

Black Engineer Officers at Fort Leonard Wood...............................................................51

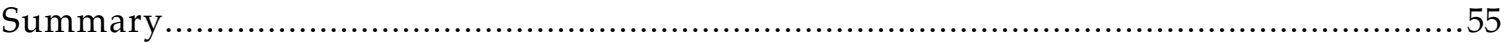

Chapter IV: Fort Leonard Wood and the Problem of Segregated Facilities..................................57

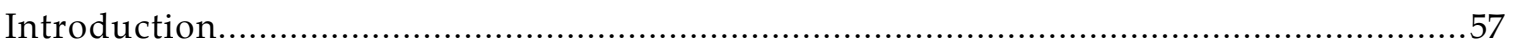

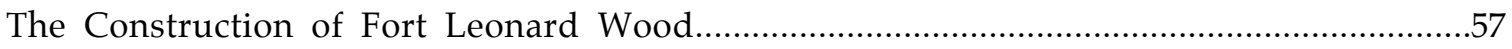

Segregated Lives, Segregated Facilities: African American Enlisted Men at Fort

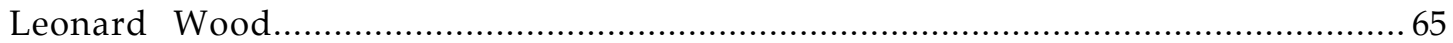

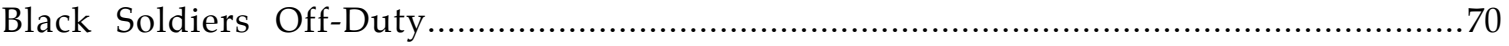

Facilities for Black Officers and the Black Officers' Club..................................................73

The Establishment of a Black Officers' Club................................................................

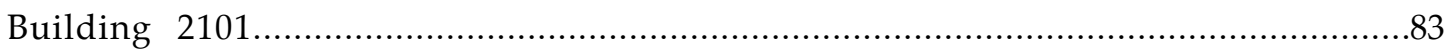

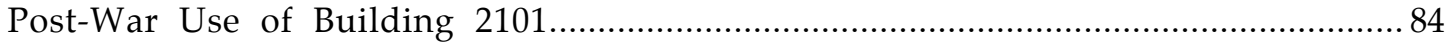

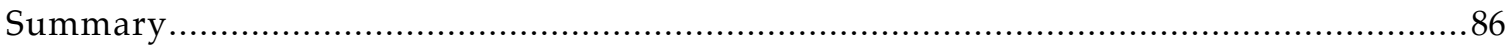


Chapter V: Samuel Countee and the Mural in Building 2101.................................................. 87

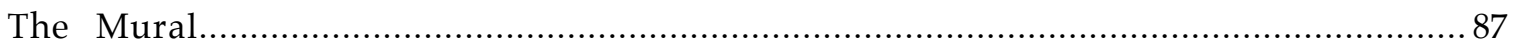

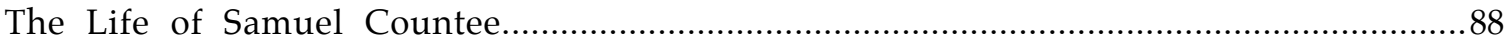

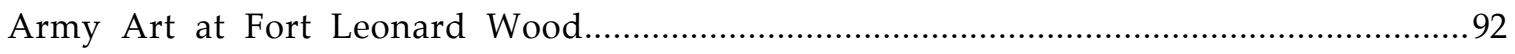

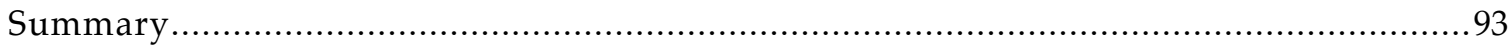

Chapter VI: The Significance of Building 2101 and its Mural..................................................95

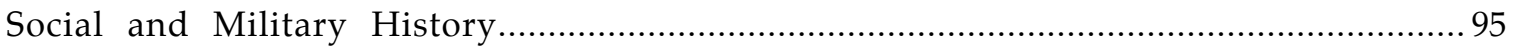

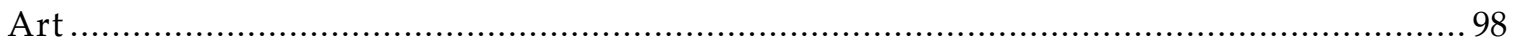

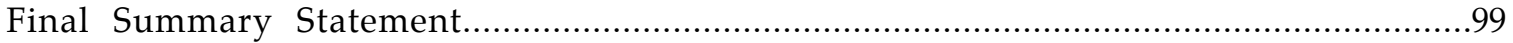

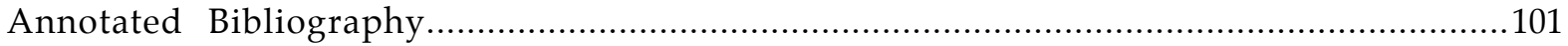

Appendix: German POW Stonework At Fort Leonard Wood, Missouri......................................... A-1

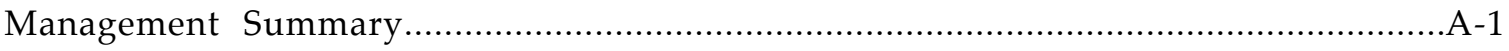

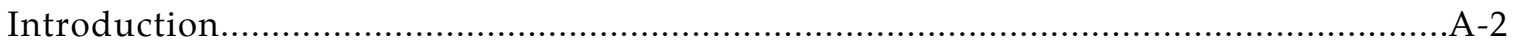

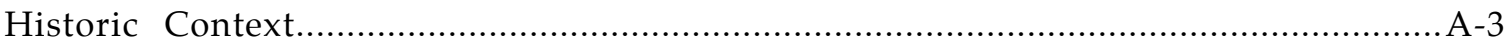

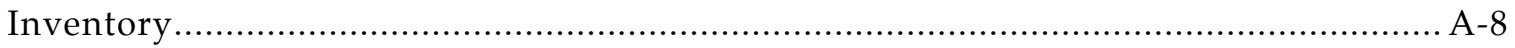

Considerations in the Determination of Historic Significance ......................................... A-8

Recommendations for Future Preservation and Maintenance..............................................A-17 


\section{LIST OF FIGURES}

Figure 1.1 Building 2101, The Black Officers' Club Today ......................................................

Figure 2.1 Motor Vehicle Driving Course at Fort Leonard Wood.............................................. 18

Figure 2.2 Organization, Fort Leonard Wood ERTC, 15 April 1941 to 9 September 1942................ 21

Figure 2.3 Organization, Fort Leonard Wood ERTC, 10 September 1942 to 9 October 1943............. 22

Figure 2.4 Organization, Fort Leonard Wood ERTC, 10 October 1943 to 9 January 1944..................23

Figure 2.5 Organization, Fort Leonard Wood ERTC, 10 January 1944 to 30 June 1944......................24

Figure 2.6 Black Soldiers on the Firing Line with Old Springfields, Fort Leonard Wood.............. 32

Figure 2.7 Pvt. Fred Pollard, Rifle Range Instructor, Fort Leonard Wood, 1942........................... 33

Figure 2.8 Enlisted Assigned or Discharged from all ERTCs......................................................35

Figure 2.9 Enlisted Assigned to Engineer Units of ASF...........................................................36

Figure 2.10 Enlisted Assigned to Engineer Units of Other Commands.......................................... 37

Figure 2.11 Enlisted Assigned to Specialist Schools..................................................................37

Figure 2.12 Enlisted Assigned as Replacements.....................................................................38

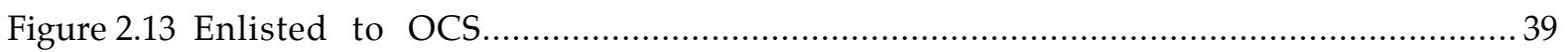

Figure 4.1 General Layout, Fort Leonard Wood, 1941..............................................................6

Figure 4.2 1941 Landscape Map of 7th Group Housing Area......................................................62

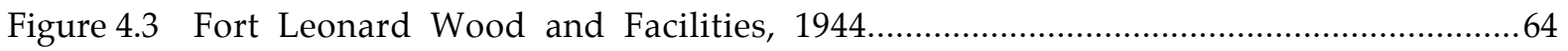

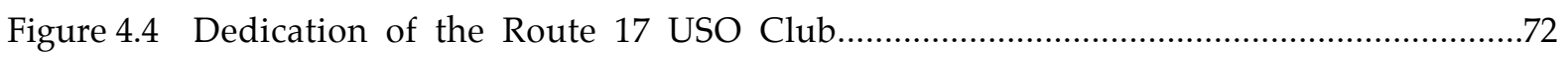

Figure 4.5 Black USO Club at Lebanon, Missouri................................................................73

Figure 4.6 Fort Leonard Wood Master Plan, 1946 Showing a Portion of the 7th's Group Area........74

Figure 4.7 Building 2101, at Fort Leonard Wood Today..........................................................77

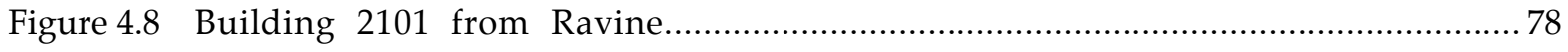

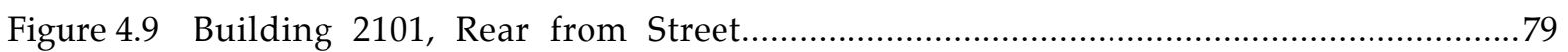

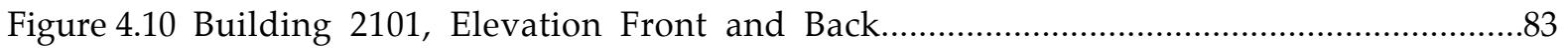

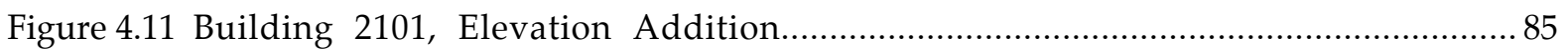

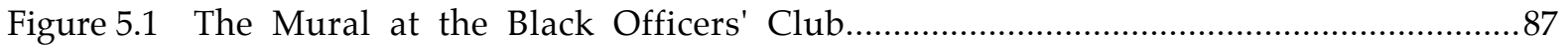

Figure 5.2 Close-up of Mural, Building 2101.................................................................. 88

Figure A-1 Stone Steps, Retaining Walls After Restoration, Building 2101...............................

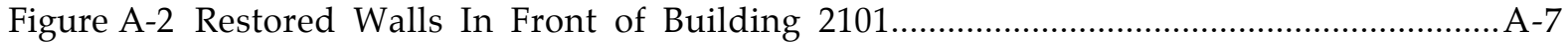

Figure A-3 POW Stonework Steps, Building 2101...........................................................

Figure A-4 Corner of Wall in Front of Building 2101........................................................ A-18 


\section{LIST OF TABLES}

Table 2.1 Fort Leonard Wood Training Schedule, 1941............................................................28 


\section{ACKNOWLEDGMENTS}

In putting this history together I'm sure I tried the patience of many individuals; the following were among the most taxed. First and foremost I must acknowledge both Dr. Richard Edging and Ms. Suzanna Walaszek. Richard, USACERL archaeologist with the Environment, Energy, and Natural Resource Division, Directorate of Public Works, Fort Leonard Wood, Missouri, is the person most responsible for preserving the historic and artistic qualities of Building 2101 through on-going, tireless efforts to obtain funding for historic research, mural restoration, and POW stonework restoration. In fact, he oversees all cultural resource compliance on post. What we know about the history and prehistory of the Fort Leonard Wood region is largely due to his efforts. Suzanna Walaszek, archaeologist and technical point of contact with the U.S. Army Construction Engineering Research Laboratories, Champaign, Illinois, administered the project for USACERL, and is tireless in her efforts to support cultural resource management at places like Fort Leonard Wood. She patiently listened to my excuses and frustrations when dead ends were reached and deadlines were not. Suzanna, Richard, and Mr. Geoffrey Burt also provided an appendix for this report regarding the POW stonework, thus relieving a major headache for me. Sincere thanks to both Suzanna and Richard for their trust in me to pursue this research. Also at USACERL, Gloria J. Wienke provided much needed technical editing along with humorous comment--and patiently turned this and another of my draft manuscripts into something resembling prose.

I am equally indebted to Dr. Larry Roberts, historian and archivist at the History Office of the U.S. Army Engineer Center, Fort Leonard Wood. Dr. Roberts, and his talented assistant archivist, Janet Fisher, provided space, copying services, scanning services, research assistance, outstanding advice, and suggestions. Dr. Roberts' interest in the preservation of historical documents pertaining to Fort Leonard Wood is intense, and years from now, when historians of our modern U.S. Army Engineer Corps write its history, they will be successful largely due to the efforts of Dr. Roberts. Two other helpful people at Fort Leonard Wood were Ruth Taylor at DPW and Dr. Robert "Kim" Combs at the Engineer Museum.

Archivists, nation wide, are an amazingly polite, professional group. Among those who helped me a great deal I would have to put at the top of the list Dr. Walter B. Hill, Jr., at the National Archives. Dr. Hill is an expert in black history and the National Archives holdings pertaining to black history. He provided good suggestions and graciously conducted a number of searches beyond the call of duty. Other National Archives archivists in the Washington area who were of great help were Will Mahoney, Terry Hannah, and Mitch Yockelson. At the Kansas City branch I was assisted by Alan Perry. At the Historical Society of Washington D.C. I was well assisted by Gail Redman. At the Center of Military History, Washington D.C., a host of historians and archivists assisted me including Dr. Robert Wright, Dr. John T. Greenwood, Marylou Gjernes, and especially Mary Hanes who was persistent in looking for some obscure manuscripts. At the U.S. Army Military History Institute, archivist Nancy Baylor conducted a search for me. I want also to thank Paul Walker and engineer historian Dr. Martin Gordon at the U.S. Army Engineers, Fort Belvoir, Virginia. In searching for information about General Grant III, I called Southern Illinois University and was happily surprised to hear noted U.S. Grant historian Dr. John Y. Simon on the other end of the line. I have had the pleasure of talking to Dr. Simon on other occasions and was frankly honored that he remembered me. He was most helpful in providing additional places to check. Mr. Edward Reep, author of A Combat Artist in World War II, University of Kentucky Press, 1987, assisted me by answering several questions about Fort Leonard Wood. Finally, I had assistance from several librarians and archivists at the Missouri Historical Society; Hamilton 
College, New York; University of Illinois; and George Washington University. The Interlibrary Loan, Government Documents, and Reference Department librarians at the Thomas Cooper Library, University of South Carolina, also deserve special mention for the great assistance, and I say that not simply because one of them happens to be my wife, Pat.

A special thanks goes to the entire Countee family and friends of Samuel Countee, without whose help we could not have confirmed that Samuel Countee painted the mural in Building 2101. Foremost on this list is Ms. Sammie Whiting-Ellis (niece) of Washington D.C., who provided much of the information regarding her uncle. Other family and friends of Samuel Countee who were most generous with their time are: Dr. Roger Countee (nephew) of Watchung, New Jersey, Ms. Robin Countee (daughter of Roger) of Washington D.C., Mr. Rutherford Countee (brother), Mrs. Martha Countee Whiting (sister), Mrs. Bernice Yates Sweeney all of Houston, Texas, Mr. Don Smith (widower of Mary Countee) of Jamaica, New York, and close friend Mr. William Greaves of New York, New York.

At the South Carolina Institute of Archaeology and Anthropology, I received solid advice and assistance from Ms. Ramona Grunden and Dr. Christopher Ohm Clement. Ramona typed the report tables and charts, and Chris edited the report, scanned images, and a million other things. Sherry Bailey handles our business affairs and keeps us out of trouble, and Dr. Bruce Rippeteau, Director, assists by keeping the hounds at bay. Although nothing herein was discovered or written sine numine, remaining errors and omissions are mine alone.

Steven D. Smith 


\section{CHAPTER I: INTRODUCTION TO THE PROJECT}

\section{Introduction and Purpose}

Early in 1941, an isolated rural portion of the Missouri Ozarks was jarred by the clamor of construction as the U.S. Army's Seventh Army Corps' new installation, Fort Leonard Wood, arose from the landscape's exhausted woodlands and fields. Amidst the threat of impending world war, Fort Leonard Wood's initial mission was to serve as a training center for both the Seventh Corps and an Army Engineer Replacement Training Center (ERTC). By 1946, over 300,000 troops had trained at Fort Leonard Wood, including the men of the ERTC, parts of the 6th, 8th, 75th, 97th, and 70th Infantry Divisions, the 72nd Field Artillery Brigade, WACs, and many smaller units. ${ }^{1}$ Among these men and women were thousands of African American soldiers.

At that time official military policy regarding African Americans was informed by a public posture of racial segregation. Thus, black soldiers were organized, trained, and housed in separate facilities apart from white soldiers. Today, many of the standard World War II (WWII) temporary military buildings in which they trained and lived are still in use, but most have been abandoned, heavily modified, or are slated to be dismantled as a result of the Military Construction Authorization Bill of 1983. ${ }^{2}$ Of those that will be preserved, few represent the experiences of African Americans in World War II as gracefully and as symbolically as Building 2101 at Fort Leonard Wood (Figure 1.1). Built originally as a standard A-12 administration building in 1941, it was modified during the war for use as the installation's Black Officers' Club. In vivid testimony to the building's former use, a large mural hangs above the building's fireplace, depicting a young black couple enjoying a picnic. The mural greatly enhances the building's ambiance and character. Lending a sense of permanence unusual for a temporary building, German POWs added finely crafted stonework around the building's outside yards in 1945. Together the building, the mural, and even the stonework stand as a unique and highly symbolic monument to African American Officers in the U.S. Army during WWII.

In 1966, the National Historic Preservation Act (P.L. 89-665, as amended) recognized that ". . . the preservation of this irreplaceable heritage [i.e. historic properties significant to the

1 Fred W. Herman, "Fort Leonard Wood, Missouri," The Military Engineer XXXIII, No. 188 (1941):108-110; Larry Roberts, "The Engineer Replacement Training Center, Fort Leonard Wood, Missouri," in Builders and Fighters: U.S. Army Engineers in World War II, ed. Barry W. Fowle (Fort Belvoir, Virginia: Office of History, United States Army Corps of Engineers, 1992), p. 93; Tom Scanlan, Army Times Guide to Army Posts (Harrisburg, Pennsylvania: The Stackpole Company, 1963), p. 269.

2 John S. Garner, World War II Temporary Military Buildings: A Brief History of the Architecture and Planning of Cantonments and Training Stations in the United States (Champaign, Illinois: U.S. Army Construction Engineering Research Laboratories, 1993), p. 6. 
Nation's heritage] is in the public interest so that its vital legacy of cultural, educational, aesthetic, inspirational, economic, and energy benefits will be maintained and enriched for future generations of Americans" (NHPA Section 1(b)(4)). This act, its regulations, and subsequent legislation required federal agencies, like the U.S. Army, to inventory, preserve, and manage historically significant buildings, archaeological sites, and objects, collectively called cultural resources. Such properties deemed significant resources are to be nominated for listing on the National Register of Historic Places. With this in mind, the building and the mural was determined eligible for inclusion on the National Register in August of 1998 by the Missouri State Historic Preservation Office. ${ }^{3}$

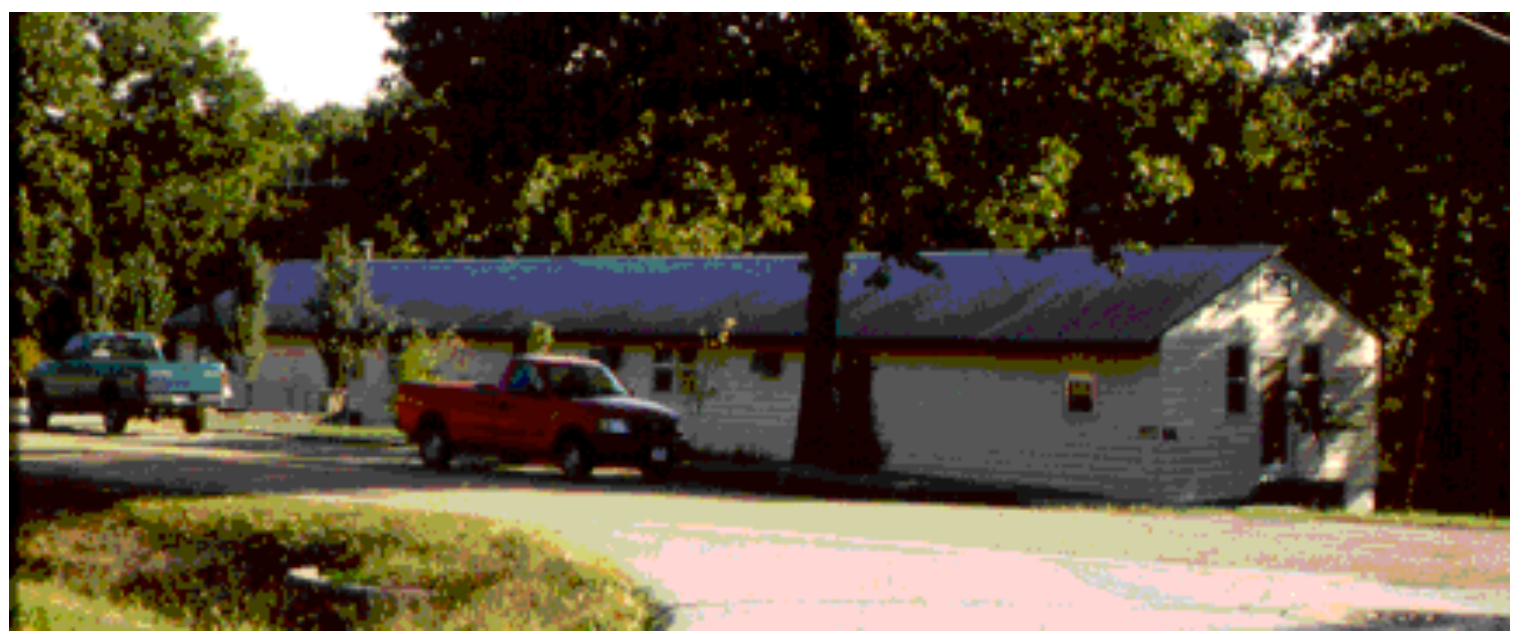

Figure 1.1 Building 2101, The Black Officers' Club, Today (SCIAA).

The primary purpose of this report is to provide a historic context statement for Building 2101. This document provides the background and context for the nomination of building 2101 to the National Register. This historic context statement and research report was prepared by the South Carolina Institute of Archaeology and Anthropology, University of South Carolina, under contract DACA88-97-Q-0262 with the Construction Engineering Research Laboratories (CERL), Champaign, Illinois for Fort Leonard Wood. Funding was provided by the Department of Defense's Legacy Resource Management Program.

\section{Research Objectives and Methods}

In developing a historic context statement for Building 2101, an additional goal of "enhance[ing] the installation and public understanding of the African American military

\footnotetext{
${ }^{3}$ Letter, Claire F. Blackwell, Director and Deputy State Historic Preservation Officer, Missouri Historic Preservation Office, to Dr. Richard Edging, HPM/Archaeologist, Fort Leonard Wood, 21 August 1998.

${ }^{4}$ Executive Order 11593, as codified in the National Historic Preservation Act of 1966, and amended, 1992, requires Federal agencies to locate, inventory, and nominate to the Secretary of the Interior all historic sites, buildings, districts, and objects under their jurisdiction that are eligible for listing on the National Register of Historic Places.
} 
experience at the installation [Fort Leonard Wood] during World War II" is an obvious secondary objective. ${ }^{5}$ Tasks necessary to achieve this goal include: 1) documenting the construction of Building 2101 and its use history; 2) conducting archival and oral history research on African American soldiers at Fort Leonard Wood during World War II, primarily those trained at the fort's Engineer Replacement Training Center $\left.(\text { ERTC })^{6} ; 3\right)$ examining the history of black officers at Fort Leonard Wood; 4) identifying, if possible the artist who painted the mural in Building 2101; and, 5) compiling a report of findings.

The method for achieving the above goals and tasks was primarily archival research at various government and private archival facilities across the nation. This was accomplished through site visits, phone calls, interlibrary loan of important documents, e-mail, and internet searches. On-site research was completed at:

National Archives, College Park, Maryland and Washington D.C.

(November 18-20, 1997, February 24, 1998)

Center of Military History, Washington D.C. (March 4, 1998)

U.S. Army Engineer Center, History Office, Fort Leonard Wood, Missouri (October 14 -17, 1997, June 10-12, 1998)

U.S. Army Engineer Museum, Fort Leonard Wood, Missouri (October 1417, 1997)

Environmental/Natural Resources Offices, Fort Leonard Wood, Missouri (October 14-17, 1997)

Thomas Cooper Library, University of South Carolina, Columbia (numerous)

Caroliniana Library, University of South Carolina (numerous)

South Carolina State Library, Columbia (numerous)

Richland County Library, Columbia (numerous)

Columbia Museum of Art, Columbia, South Carolina (numerous)

Additional research was conducted with the assistance of professional archivists via the telephone, post, or e-mail at:

Missouri Historical Society, St. Louis, Missouri

National Archives, College Park, Maryland and Washington D.C.

National Archives, Kansas City Branch

Center of Military History, Washington D.C.

U.S. Army Engineer Center, History Office, Fort Leonard Wood, Missouri

U.S. Army Engineer Museum, Fort Leonard Wood, Missouri

Fort Belvoir Corps of Engineer Library, Fort Belvoir, Virginia

U.S. Military History Institute, Carlisle Barracks, Pennsylvania

Columbia Historical Society, Washington D.C.

Southern Illinois University, Carbondale, Illinois

George Washington University, Washington D.C.

Hempstead Public Library, Hempstead, Long Island

\footnotetext{
5 "Black Officers' Club Historical Documentation Fort Leonard Wood, Missouri," Statement of Work (Champaign, Illinois: Construction Engineering Research Laboratories, August 1997).

${ }^{6}$ In 1944 the ERTC was renamed the Army Service Forces Training Center (ASFTC) recognizing that it was under the administrative control of the Army Service Forces. In this report, the training center is generally referred to as the ERTC, changing to the ASFTC as primary sources dictate. For the reader, the two terms can be considered synonymous.
} 
Morale, Welfare, and Recreation, Arts and Crafts Program, U.S. Army Community and Family Support Center

William Greaves Productions, Inc., New York, New York

Hampton University Museum, Hampton, Virginia

National Museum of Art, Smithsonian, Washington D.C.

Veteran's Hospital Cemetery, Farmingdale, New York

School of the Museum of Fine Arts, Boston, Massachusetts

Third World Art Exchange, Los Angeles, California

Schomburg Center for Research in Black Culture

Museum of African American Life and Culture, Dallas, Texas

Generally, key-words and phrases that guided research were:

African Americans in the Military--black soldiers, Negro soldiers, segregation, integration in the armed forces, Negro officers

Fort Leonard Wood-- construction history, installation history, facilities, building use, post-war use

U.S. Army, Seventh Army Corps, mobilization, policy on Negro soldiers and officers, prewar plans, post-war integration

U.S. Army Engineers--ERTC's, Negro soldiers, Negro officers, training, facilities

U.S. Army Special Services Facilities Section, Soldier Art Program

Samuel Albert Countee

\section{Previous Research and Preservation Regarding Building 2101}

Prior to the conduct of this research, there had been three previous studies incorporating some historical research regarding Building 2101, the Black Officers' Club. Malcolm C. Drummond and Richard P. Zerega of Harland Bartholomew \& Associates, Inc., conducted research on the stone structures built by German prisoners of war (POW) at Fort Leonard Wood, including the walkways, ditches, walls, and chimney surrounding Building 2101. The project goals were to evaluate the stone work and determine which edifices were eligible for listing on the National Register of Historic Places. Research into the history of POWs at Fort Leonard Wood played a part in this assessment. The study concluded that of the 60 different stone work "structures," three-fourths were constructed by the POWs, the remaining were constructed by American troops or professionals and were of recent origin. Some $70 \%$ of the POW stoneworks were recommended as worthy of continued preservation or maintenance and 12 were considered eligible for the National Register. ${ }^{7}$

The report makes mention of Building 2101 several times, but primarily in connection with the stonework surrounding the building. Drummond and Zerega note that the stonework there has had three major alterations since its construction by POWs:

The drainage structure separating the terrace area from the rear yard has been built over with a wooden cover and overlaid with soil and sod. A concrete overlay has been applied over

\footnotetext{
7 Malcolm C. Drummond and Richard P. Zerega, Cantonment Historical Resources Survey, Fort Leonard Wood, Missouri (Chesterfield, Missouri: Harland Bartholomew \& Associates, Inc., 1987).
} 
the front steps, and red paint has been placed on the front of the interior fireplace. ${ }^{8}$

They concluded that these alterations could be easily corrected, and restoration of the stonework was completed in $1995 .{ }^{9}$

Drummond and Zerega also recorded that they had made contact with several local informants, two of whom mention the Black Officers' Club. Ms. Mary Jo Loving of Rolla, Missouri, was noted as working at the Engineer Replacement Training Center during World War II and she knew black officers at the installation. ${ }^{10}$ Ms. Loving was contacted by the present author on March 10, 1998. Unfortunately, the report was unintentionally misleading regarding her knowledge of the Black Officers' Club, Building 2101. Ms. Loving worked at the ERTC during WWII, however, she worked at the ERTC Headquarters Building and has no memory of black officers during the war or of the building. She returned to work for Fort Leonard Wood after it reopened during the Korean conflict, and at that time remembers black officers stationed at the post. The other informant mentioned was Mr. Larry Adkins who is recorded as having guarded the POWs while they worked around the Black Officers' Club. He remembered that they built the steps, walls and chimney. Mr. Adkins was contacted by the author on March 4th, and again March 20th, 1998. Unfortunately, Mr. Adkins was very ill and could not be interviewed.

The second and third projects connected to the Black Officers' Club were conducted by Harland Bartholomew \& Associates, Inc., and the Construction Engineering Research Laboratories (CERL). ${ }^{11}$ The report by Harland Bartholomew \& Associates, Inc., documented the Black Officers' Club's use history as part of an installation-wide buildings inventory. It concluded that Building 2101 was eligible for listing on the National Register. The CERL report documented restoration work completed on the mural and provided some cursory information regarding the building's history, however, not within its full context and association with the ERTC and the black military experience during WWII. Importantly, both reports introduce a central mystery regarding the building's origin. In both reports, Mr. Kim Combs, curator of the U.S. Army Engineer Museum on post related that he interviewed a WWII veteran who indicated that the Black Officer's Club was built after the initial post construction, as a result of an order by ERTC commander General Ulysses S. Grant III. ${ }^{12}$ According to this story, two black officers entered the Officers' Club for an important 8 Ibid., p. 34.

${ }^{9}$ Douglas C. Hicks, Masonry Repairs To POW Stonework, Black Officers' Club, Fort Leonard Wood, Missouri (Williamsport, Maryland: Williamsport Preservation Training Center, Harpers Ferry, 1995).

${ }^{10}$ Drummond and Zerega, Cantonment Survey, p. 83.

${ }^{11}$ Harland, Bartholomew \& Associates, Inc., Installation Building Survey of April 1992: Report of Findings at Fort Leonard Wood, MO (Army Engineer District Kansas City: April 1992); Don Kermath, Amy J. Lamb, Tracy Hewitt, Doug Hicks, Rick Strilky, and Robert Score, Historic Restoration of the Black Officers' Club at Fort Leonard Wood, Missouri (Champaign, Illinois: on file, USACERL, draft manuscript, 1996).

${ }_{12}$ The reports states that General Grant was commander of the installation. Actually, he was commander of the Engineer Replacement Training Center. The post commander in 1941 was Major General Clarence S. Ridley, Souvenir Book, Engineer Replacement Training Center, Fort Leonard Wood, Missouri (Fort Leonard Wood, Missouri: on file, U.S. Army Engineer Museum, ca.1941). 
social function attended by Grant. The officers were asked to leave the club and construction of their own club was authorized immediately afterwards. ${ }^{13}$ However, the CERL report indicates that this story is contradicted by the fact that the building was indeed built during initial construction, was first used as a Personnel Adjutant's Office, and the first documentation of it being a Black Officers' Club was in the form of a post telephone book dated January 1943. ${ }^{14}$ Indeed, Building 2101 was standing by June 21, 1941, having been completed probably as early as March. ${ }^{15}$ Further discussion regarding the story's authenticity will be discussed in Chapter IV. However, the author interviewed Mr. Combs on October 15, 1998 and Mr. Combs could not remember the informant's name, closing that research link.

In summary, several reports previously had provided tantalizing glimpses into the potentially unique history of Building 2101. These references and the wonderful mural in the building inspired the Environment, Energy, and Natural Resource Division at Fort Leonard Wood to seek additional research focused on Building 2101's use history, and African Americans in the U.S. Army and the ERTC. The Department of Defense Legacy Resource Management Program agreed with the importance of this research and funded this project to develop an in-depth historic context for Building 2101.

\section{Report Organization}

Providing a context for understanding the significance of Building 2101 became a complex goal. Understanding why the building was designated as the exclusive club for black officers, a seemingly simple, focused objective, becomes a broader task as one attempts to frame its context. Eventually the research dramatically expanded requiring an understanding of U.S. Army Policy, Fort Leonard Wood's history, the history of the Army Engineer's ERTC, and the overall treatment of black soldiers in WWII. Research on the mural artist and Army artists during WWII, adds another aspect to the research. In telling the story, one must then organize these disparate parts into a hopefully coherent and progressively narrowing focus back on Building 2101. Thus, the research and this report took on its own life and organization, as follows.

Chapter II begins by relating U.S. Army Policy regarding the planned use and mobilization of African American soldiers prior to WWII. This is then followed by an overview of mobilization within the U.S. Army Engineers and the ERTC. With this foundation, a history of Fort Leonard Wood's ERTC is discussed with special reference to the experiences of black enlisted men. Only

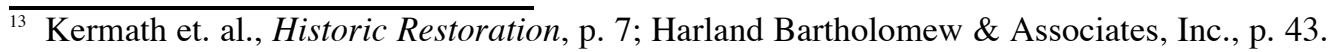

${ }^{14}$ Kermath et. al., Historic Restoration, pp. 7-8; Fort Leonard Wood Telephone Directory (Fort Leonard Wood, Missouri: History Office, U.S. Army Engineer Center, January 1943), p. 35.

15 "Individual Building Report For Historical Record, Buildings 1652, 1653, 1757, 1759, 1913, 2101, 2102," (Fort Leonard Wood, Missouri: on file, History Office, U.S. Army Engineer Center). The June completion date is for all seven buildings, the March date comes from the Directorate of Public Works Property Report Card.
} 
after this framework is built, can what little is known about the black officers in the U.S. Army Engineers be described in Chapter III, again broadening as necessary to describe the Army's treatment of black officers generally, and then at the ERTC.

Chapter IV again steps back to a broader view, relating the construction history of Fort Leonard Wood and the ERTC. Central to this discussion is an examination of one of the more troubling aspects of racial segregation in the military, that being the policy of segregated facilities, first for the enlisted and then regarding black officers. With this context in place Chapter IV then focuses on the use history of Building 2101. The building is described in detail and the chapter concludes with brief a post-war use history of the building.

Chapter V is a brief discussion of the life of Samuel Albert Countee, who was the artist of the mural in Building 2101. His name heretofore had been unknown--the signature on the mural being obscured by wear and tear. The chapter describes the mural and relates what currently is known about Mr. Countee's life.

In summarizing the findings of this report, Chapter VI provides a significance statement for Building 2101. As a goal of Fort Leonard Wood is to nominate the building for the National Register of Historic Places, this chapter can be used for completing the nomination statement. Two sections end this report. The first is a annotated bibliography of sources for future Fort Leonard Wood researchers. The second is an appendix, authored by Geoffrey Burt and Suzanna Walaszek of the U.S. Army Construction Engineering Research Laboratories, and Dr. Richard Edging of Fort Leonard Wood's Directorate of Public Works, incorporating details about the POW stonework at Fort Leonard Wood, Missouri. As the stonework at Building 2101 is among the most elaborate of the existing stonework at Fort Leonard Wood, and its restoration was a major component of the building's restoration project, it is appropriate to include this data in this report. 


\section{CHAPTER II: AFRICAN AMERICANS AND THE ENGINEER REPLACEMENT TRAINING CENTER, FORT LEONARD WOOD, 1941-1946}

At first glance Building 2101 would appear to many today as a modified but standard temporary WWII military building. However its use history makes it symbolic of an important segment in the long struggle for African American civil rights. In order to understand its symbolism and its significance, it is necessary to understand the context in which a standard A-12 Personnel Adjutant's Office became the Black Officers' Club during WWII. This chapter provides a brief history of U.S. Army policy toward African Americans leading up to and including WWII, and a history of the Engineer Replacement Training Center, Fort Leonard Wood, Missouri, from 1941 to 1946 with special emphasis on the black troops.

\section{Pre-War African American Military Policy}

As the Army prepared for world war in the late 1930s, government policy makers once again faced the question of African American participation in the military. American culture history, previous military policies, the perceived record of African American soldiers during WWI, intractable racial prejudice at all levels of society, and pressure from civil rights activists, all served to influence Army policy that, in retrospect, exacerbated the already difficult tasks of mobilization and utilization of black manpower during WWII. It is within this complex web that Army policy must be understood, either as the best that the Army could offer given the attitudes prevalent at the time, or as would be judged today--wrong-headed and racist.

At the end of WWI, the Army began planning for the future use of black personnel and recognized two major concerns. The first was--what was the place of the black soldier in the rapidly shrinking peacetime Army? The second closely related problem was, how would blacks be used in future mobilization? In attempting to answer these questions, the Army unfortunately turned to its immediate past experience in the Great War. This limited perspective ignored the positive contributions of African American soldiers during the 19th century, especially the enduring service of black Civil War, Indian War, and Spanish American War veterans. Colonel Charles Ballou, commander of the all-black 92nd Infantry Division in WWI and an influential spokesman on the subject, went so far as to state that the use of African American soldiers during the Civil War and in the western campaigns was "not instructive." ${ }^{1}$ Instead, when shortly after WWI the Army decided to set official policy on the future employment of black troops, they looked very narrowly

to the experiences of white commanding officers in the 92nd--not exclusively, but with much greater ${ }^{1}$ Colonel C.C. Ballou to Assistant Commandant, General Staff College, "Use to be Made of Negroes in the U.S. Military Service," 14 March 1920, in Morris J. MacGregor and Bernard C. Nalty, editors, Blacks in the United States Armed Forces, Basic Documents, Volume IV, Segregation Entrenched (Wilmington, Delaware: Scholarly Resources, Inc., 1977), p. 321. 
scrutiny than the record of other black military units. ${ }^{2}$ Indeed, the testimony of white commanders in the 92nd provided the bulk of both the opinions received by the War Department and the answers to questionnaires sent out by the Army War College. This testimony was overwhelmingly negative, concluding that the 92nd Division was a failure.

True, on the surface the 92nd's combat record pointed directly to such a conclusion; the division's performance in the Muese-Argonne Offensive and in the Marbache Sector was uneven at best. $^{3}$ But its failure was not the result of its soldiers' skin color. The 92nd consisted of draftees who never trained as a division in the United States. Some $40 \%$ of the men were illiterate and many were drafted despite being physically unfit. $^{4}$ In France, the division was given inadequate preparation for trench warfare. Many 92nd units were given only two weeks indoctrination before being thrown into the frontlines, some were given only a few hours, and their initial duties and training had consisted of police duty. Meanwhile, the 92nd's staff officers were being shuffled in and out constantly, eliminating any opportunity to build unit cohesion. When ordered to the front, the 92nd marched without rifle-grenades, wire cutters, and even in some cases without maps.

Poorly equipped and led by green, inexperienced officers, it should have been no surprise that the division's combat performance would fail to meet Army standards. And yet, despite this neglect, some units of the 92nd earned awards and citations. General John J. Pershing remarked that the 92nd's record stood "second to none." But 2nd Army Commander General Robert Bullard's comments held greater weight--"Poor Negroes," he wrote in his memoirs, "They are hopelessly inferior." Bullard was not alone in his disparagement. Repeatedly, white officers complained that black troops dawdled in combat and showed cowardice. They recommended that in future wars, African American soldiers should be limited to labor battalions. If used in combat at all, they must have intensive training. Further, they must be led by white officers. ${ }^{6}$

${ }^{2}$ Ulyssess Lee, The Employment of Negro Troops, United States Army In World War II, Special Studies, (Washington: Office of the Chief of Military History, United States Army, 1966), p. 16. This classic study, and the following other works were used in the development of this section: Bernard C. Nalty, Strength For the Fight (New York: The Free Press, 1986); Morris J. MacGregor, Jr., Integration of the Armed Forces 1940-1965 (Washington: Center of Military History, United States Army, 1981); Steven D. Smith and James A. Zeidler, editors, A Historic Context For the African American Military Experience, Department of Defense, Legacy Resource Management Program (Champaign, Illinois: Construction Engineering Research Laboratories, 1998).

${ }^{3}$ Keith Krawczynski, "Chapter 6, World War I," in Smith and Zeidler, editors, Historic Context, p. 237.

${ }^{4}$ Lieutenants W.N. Colson and A.B. Nutt, "The Failure of the Ninety-Second Division," The Messenger, September (1919):22-25.

${ }_{5}^{5}$ Pershing quoted in Emmett J. Scott, Scott's Official History of the American Negro in the World War (New York: Arno Press, reprint 1969, original 1919), p. 167. Bullard quote from Lee, Employment, p. 15. Bullard was a reputed racist and further his memoirs were written to discredit his personal rival, General Charles C. Ballou, commander of the 92nd. See Arthur E. Barbeau and Florette Henri, The Unknown Soldiers: Black American Troops in World War I (Philadelphia: Temple University Press, 1974), pp. 139-140.

${ }^{6}$ see Ballou, "Use,"; Lieutenant Colonel Allen J. Greer to Assistant Commandant, General Staff College, "Use to be Made of Negroes in the U.S. Military Service," 13 April 1920, in Morris J. MacGregor and Bernard C. Nalty, editors, Blacks in the United States Armed Forces, p. 329; Major General W. H. Hay to Colonel Greer, 13 April 1919, in Morris J. MacGregor and Bernard C. Nalty, editors, Blacks in the United States Armed Forces, p. 331. 
Meanwhile, in evaluating the wartime performance of black soldiers, the Army decidedly ignored the 92nd's sister division, the 93rd. This division's performance painted a different picture. The 93rd was manned by National Guard units from New York, Illinois, Ohio, Maryland, Tennessee, Connecticut, Massachusetts, and the District of Columbia, with only one draftee regiment. It lacked support units and in reality the division performed in individual regiments rather than as a single, coherent division. But critically in France the 93rd was put under French Army command. Desperate for manpower, the French Army and people warmly welcomed these black reinforcements. The French reorganized the division along their own designs and provided its regiments with French equipment. Furthermore, the division was given orientation time and training in trench warfare before being thrown into the frontline. Practically across the board, the regiments of the 93rd performed well, and the record of the 369th and 371st regiments were simply outstanding. The 369th was on the front lines for 191 days, five days longer that any other regiment in the American Expeditionary Force. They never lost a foot of ground, and essentially bled to death in the trenches before finally being pulled from the front. France awarded the entire unit the Croix de Guerre. The 371st was also awarded the Croix de Guerre, with palm, for their performance. Three officers of the 371st won the French Legion of Honor, 123 men won individual Croix de Guerre medals, and 26 won the Distinguished Service Cross. ${ }^{7}$

Back in post-war America, the 93rd's record was ignored and the 92nd's ineffective record stood as the standard measure of black combat performance. Setting a tone for WWII, the failure of the black enlisted men was laid squarely at the feet of the black officer. Colonel Fred Brown, commanding officer of the 92nd's 368th Battalion, concluded in his "The Inefficiency of Negro Officers," that black officers were cowards. Other white commanders agreed. Black officers were charged with failing to take care of their men. They lacked initiative and were not respected by black enlisted men. Lieutenant Colonel Greer, Chief of Staff of the 92nd Division, asserted, "I do not remember a single patrol report coming from an officer that gave sufficient information to base any plan thereon." In testimony after testimony, white officers complained that black officers were a disaster--regardless of their training as either Regular Army officers or as Officer Candidate School graduates. The evidence for their failure seemed to be bolstered by the improved performance of African American units that replaced its black officers with white. Undoubtedly black officers overall had a sub par record, but racial slander and personal prejudices are clear and unabashed in these reports. One white commander commented that, "The fact that a Negro holds a commission, leaves him still a Negro." Another went so far as to declare that black men never had the benefit of moral training at home and therefore did not know right from wrong. ${ }^{9}$

In reviewing the performance of black officers in WWI, white commanders not only ignored their own inadequate training of black soldiers and their own personal prejudices, but also the

${ }_{7}$ Krawczynski, in Smith and Zeidler, editors, Historic Context, p. 218.

${ }^{8}$ Hay, "Use," p. 329.

${ }^{9}$ Hay, p. 332; Brigadier General W.P. Jackson to Colonel Allen J. Greer, 14 April 1919, in Morris J. MacGregor and Bernard C. Nalty, editors, Blacks in the United States Armed Forces, p. 339. 
larger societal inequalities that clearly contributed to a black soldier's individual failure, either as enlisted men or officers. First, there was the problem of years of inadequate education. Contrary to popular belief, a good soldier needs to be well-educated, or at the least, know how to read and write. Many drafted blacks were illiterate. Blacks also had been denied skilled labor positions in the civilian world--skills that would have given them the chance to succeed as specialists in the military. They also has been denied leadership opportunities that would have improved their chances to be successful officers. During the war, some 700 black men were chosen to train at the new black officer training school at Fort Des Moines, Iowa. But these men were not chosen from the best candidates available--only 12 per cent were rated as above average. Once graduated, they were transferred to units irrespective of the special training they had received; for example, infantry officers were transferred to field artillery units. Upon entering a command new black officers found white officers reluctant to serve with them and white enlisted often openly contemptuous of their authority. Even with experience they were denied promotion and opportunities to build leadership skills. In one example, a large group of black officers were sent to Fort Dix, New Jersey, where they sat for months waiting assignment or even some basic temporary duties. Only a few black National Guard officers rose to Major or above.

Behind such treatment was the unmistakable conclusion that many Army commanders did not want black officers, but pressure from the African American community demanded the opportunity for blacks to serve at all levels, so black officers were commissioned, but with no sincere efforts made to integrate them into the officer corps. Reluctantly then, the Army eventually commissioned some 1,353 black officers to serve during the war. ${ }^{10}$ Meanwhile, for future policy makers, the conclusions drawn from WWI were that the black soldier was an inferior soldier who required more intensive training than the white recruit. Blacks were not disposed towards aggressive combat, but if led by white officers, they could be useful in labor units and at unskilled jobs. The African American officer was a decided failure.

With these conclusions drawn and seemingly proven by WWI experiences, post WWI planning for the future use of blacks in the military put Army planners and policy makers in a complex bind. Consider for example the immediate problem of drastically downsizing the Army across the board. Congress had created four all-black regiments after the Civil War. This left the Army with the very real and distasteful possibility of having a disproportionate number of African Americans in its post-war Army. The problem was exacerbated by the large number of blacks who wished to reenlist and the close scrutiny by the black press as to exactly how blacks would fare in the future Army. The quick solution to the possibility of a disproportionate number of blacks in the Army was to immediately and severely curtail black enlistment. Meanwhile the Army began reducing the all-black units to mere token size. Through the 1920s, the once-proud 9th and 10th Cavalry and the 24th and 25th Infantry regiments barely survived. While their unit designation continued on the active list, they were converted into service or housekeeping units.

\footnotetext{
$\overline{{ }_{10}}$ William H. Hastie, "Negro Officers in Two World Wars," Journal of Negro Education 12 (1943):312-323.
} 
When the Army Air Corps was formed in 1931, blacks were excluded from joining. Adding to this insult, precious vacant personnel slots in the 10th Cavalry were allotted to the exanding air arm. ${ }^{11}$

The black soldier became a rare sight during the 1920s and 1930s. Black enlistment was, for all practical purposes, limited to those all-black National Guard units in New York, Massachusetts, Maryland, Illinois, New Jersey, and the District of Columbia. For a black man to enter the Regular Army, he had to find an installation with a vacancy, apply to the base commander, and if accepted, get to the post at his own expense. Such opportunities were sparse. Further, these conditions would have been difficult in Depression-weary America for anyone, and for blacks they were a formidable challenge. The result was that by 1930, the combined black complement in the Regular Army and Army National Guard was only two percent of the total Army population. Throughout this period, the black officer corps was virtually invisible. In 1940, there were less than 10 active black Regular Army officers, around 300 Reserve officers, and around 200 black men commissioned in National Guard units. ${ }^{12}$ This figure included line officers of all ranks, medical officers, and chaplains.

Meanwhile, throughout the decades of the 1920s and 1930s, Army planners struggled with the solution to the black mobilization problem should war come again. It was clear that in any future war, the African American would have to be used, but how, in what proportion, and how was the Army going to accomplish its mission without offending blacks or whites? In 1922 the War Department's Operations and Training Section developed its first plan for black mobilization, and although it was modified and amended more than once, its fundamentals stood until 1938--and even then influenced the 1940 final pre-plan as mobilization began. Amazingly, given the discouraging reports by WWI commanders, the public attitudes prevalent at the time, and the treatment of blacks over the coming 20 years, Army policy makers began their 1922 plan with an enlightened, realistic perspective on the future use of blacks in the military. In precise clear language, the War Department addressed the military realities:

Briefly, these [military realities] are: that the Negro is a citizen of the United States, entitled to all of the rights of citizenship and subject to all of the obligations of citizenship; that the Negro constitutes an appreciable part of our military manhood; that while not the best military material, he is by no means the worst; that no plan of mobilization for the maximum effort can afford to ignore such a fraction of the manhood, especially in these times when war makes demands upon the physical defectives and the women; and finally, that in a democracy such as ours political and economic conditions must be considered, and that decision must rest upon these two considerations." ${ }^{\text {13 }}$

\footnotetext{
${ }_{11}$ Nalty, Strength, pp. 128-129.

12 Hastie, "Negro Officers," pp. 318-319.

${ }^{13}$ Lee, Employment, pp. 32-33.
} 
The 1922 plan concluded that blacks soldiers should operate in smaller units than the divisions used in WWI. Generally, according to the perceived wisdom of that time, blacks worked well in regiments or smaller units, brigaded or otherwise attached to a white unit. Blacks would definitely have to be used in combat. The plan stated that as far as combat material went, about half the blacks in WWI were effective. The plan recognized that it also had to filter through white draftees to find suitable combat material. Some frank statements and recommendations concerning black officers were made also. It openly admitted that black officers performed well under the French. Further, it asserted that black soldiers were best led by white officers, but that qualified black officers could be found, and that African Americans could not be expected to serve and do their best if they were not offered the incentive of promotion into the officer corps. The solution to the officer problem was to hold black candidate officers to the same standard as the Army held white candidates and let the best rise to the top.

As noted, the Army revised, changed and debated different mobilization plans throughout the period between 1922 and the summer of 1940 when the great pre-war expansion began. These plans often met resistance. The Chief of Engineers, for example, objected to the inclusion of African Americans in the Organized Reserves, the pool of men from which the Corps expected to draw its initial manpower during mobilization. He asserted that service units needed highly qualified men who could perform demanding technical skills under combat stress and therefore, all engineer units should be white. This exclusion was refused by the War Department. ${ }^{14}$ Major revisions came in 1937 and again in 1940, the majority of which concerned the proportion of blacks to whites in various unit types.

Historian Ulysses Lee has summarized these changes and the general policies which were in effect on the eve of WWII. ${ }^{15}$ First, blacks would be represented in the Army in equal proportion to their proportion of the total military age manpower available. It was suggested that they be mobilized early to allow their practically nonexistent pre-war numbers to grow to nine-plus percent of Army manpower. Second, blacks would serve in all service and combat units for which they could ${ }_{14}$ Ibid., p. 35.

${ }^{15}$ For the purposes of brevity, this section omits the complex and fiery political debate regarding black participation in the impending war. Readers should be aware that black leaders, black activists and the black press demanded equal representation in all service arms and full integration. The 1940 NAACP annual conference focused much attention on the armed forces and the coming war. Letters swamped the War Department with questions about the planned mobilization. Slowly, such efforts began influencing war policies although not to the full extent desired. President Roosevelt, in anticipation of the upcoming election, issued a series of press releases assuring black voters that there would be proportionate opportunities in the armed forces. $\mathrm{He}$ also issued an Executive Order banning racial discrimination in government employment at defense plants. In other efforts to assuage black voters, famous black Army officer Benjamin O. Davis was promoted to Brigadier General and black leader William H. Hastie was selected as a civilian advisor to the Secretary of War. Throughout the war, black leaders watched and questioned the military's treatment of black men and women. Meanwhile the black press began calling for a "Double V" campaign, meaning a victory over the fascists abroad and Jim Crow at home. These efforts would eventually result in the integration of the armed services. For detailed treatments of this complex issue see the above citations, and A. Russell Buchanan, Black Americans in World War II (Santa Barbara, California: Clio Books, 1977). 
qualify. Third, blacks would be segregated into all-black units, and attached to larger white units. Fourth, black soldiers would be trained, housed and provided for in the same manner as whites (but separate from whites). Finally, the black officer problem was resolved as follows: 1) officers for black units could be black or white; 2) black officer candidates would be held to the same qualification standards as whites; 3) black officers would only serve in black units (i.e., command only black troops); and 4) black officers would be confined to designated units, and at first this would consist of Reserve, National Guard and service units. ${ }^{16}$ In September 1940, the Selective Training and Service Act was enacted and the great Army expansion began in response to world war. The act boldly forbade discrimination on account of race or color in the selection of volunteers and draftees. By December 1942, the number of blacks enlisted in the Army had increased from a 1939 level of 3,640 men to 467,883. ${ }^{17}$ This trend continued throughout the war. Total African American representation in the military climbed as high as 701,678 in September 1944 and as high a total percentage as $8.81 \%$ in December 1945. Enlisted personnel reached the $10.29 \%$ figure that same month. ${ }^{18}$

But as the expansion continued, the societal and institutional problems inherent in segregation, and seen in WWI, were once again manifest during WWII. Again, there was the problem of unqualified black volunteers and draftees (either as a result of low scores on intelligence tests or because of physical limitations) being selected to fill quotas. Again, racial intolerance and resistance weakened the effectiveness of the Army's training programs. As will be clearly demonstrated at Fort Leonard Wood, separate but equal policies created quota difficulties, facility problems, and training problems regarding black soldiers. During the later years, from 1943 onward, as more and more black units were converted into service units and opportunities for advancement did not appear, black soldier and officer morale sagged again as it had during WWI. Racial incidents on and off posts again resulted from these tense circumstances. With the advantage of retrospect though, some positive advances were being made simply by the fact that whites and blacks who had never worked together were being forced together to win a war. Conflict was inevitable, but so was a slow, growing acceptance, or at least exposure to other races, which must have affected and increased tolerance. Combat, the great equalizer, would prove again to a large number of Americans that blacks were like whites--some brave, some not so brave. But both bled red, and with proper training, both could soldier. There was, of course, still a long way to go at the end of WWII, but these lessons were being learned and relearned at installations across the nation, including the recently constructed engineer replacement center in the Missouri Ozarks, named Fort Leonard Wood.

\footnotetext{
${ }_{16}$ Lee, Employment, p. 50.

17 Ibid., p. 88.

18 Ibid., p. 415.
} 


\section{Mobilization and The Engineer Replacement Training Centers}

The U.S. Army Corps of Engineers was, like all other branches of the Army, experiencing a "raging torrent" of expansion at the onset of WWII. Draft-fed enlisted strength in the Corps rose from 9,973 to 69,079 in 1941, a sevenfold increase. ${ }^{19}$ The problem of turning young civilians into soldiers even before they could become combat engineers was placed initially in the hands of individual engineer units. By the summer of 1941 this became untenable and fortunately by that time two new replacement training centers were up and running--one at Fort Belvoir, Virginia, and the other at Fort Leonard Wood, Missouri. ${ }^{20}$ The responsibility for training basic engineer soldiers to be used to fill new units and later replace casualties was shifted to these installations. With two installations devoted exclusively to turning out engineer troopers, basic soldiering and engineering could be taught with some semblance of standardization while combat and service units could concentrate on their responsibilities.

Yet though the training centers were hatching engineer soldiers as rapidly as possible, some 5,000 fillers a month, they still could not keep up with the demand needed to fill the profusion of newly-activated engineer units. ${ }^{21}$ Throughout 1942 and into 1943 demand increased, and several solutions were attempted. The first, as early as December 1941, was to decrease training time from 12 weeks to eight weeks, and to assign graduates exclusively to fill units on the verge of overseas deployment. ${ }^{22}$ Units remaining for the moment within the Zone of the Interior (ZOI) would have to wait. But in March 1942 this plan was scrapped. Eight weeks simply was not enough time to turn a civilian into an engineer soldier, so the 12 week program had to be restored. Even the 12 week course produced a soldier with only the most rudimentary engineering skills. But given the war circumstances and the critical need for men, especially during the initial stages of the war, these men would have to learn and hone their engineering skills on the European and Pacific battlefields. The demand continued and amazingly, the 79,571 engineer soldiers Forts Leonard Wood and Belvoir produced in 1942 was still not enough, and a multitude of other solutions were adopted. ${ }^{23}$ The Army Air Corps, tired of waiting, decided to set up their own facilities to train the engineer troops they needed. Another solution was to establish yet a third ERTC at Camp Abbott, Oregon. But any workable solution was doomed to a short life as wartime demands changed continually, causing the on-going necessity to revise training programs.

\footnotetext{
${ }_{19}$ Blanche D. Coll, Jean E. Keith, and Herbert H. Rosenthal, The Corps of Engineers: Troops and Equipment, United States Army in World War II, The Technical Services (Washington D.C.: Office of the Chief of Military History, 1958), p. 116.

${ }^{20}$ Altogether the Army created 21 replacement training centers for various arms and services, see Leonard L. Lerwill, The Personnel Replacement System in the United States Army (Washington D.C.: OCMH, original 1954, reprinted 1982), p. 249.

${ }^{21}$ These men were called "fillers" because they filled out the unit as opposed to "replacements" who would be used to replace men lost as casualties.

${ }^{22}$ It should be noted that the Army Engineers were not acting alone. All arms and services, except Armor, Infantry, and Signal Corps cut their programs to eight weeks in response to the demand for fillers created by the declaration of war after Pearl Harbor, see Lerwill, Replacement System, p. 357.

${ }^{23}$ Col, Keith, and Rosenthal, Troops and Equipment, p. 174.
} 
Indeed, the manpower shortage at the war's beginning, the quotas throughout the war, the manpower surplus toward the war's end, and the shifting demands of the Corps of Engineers and the War Department created an atmosphere of constant, vibrant change at the ERTCs from the moment the first soldier entered the gates until they closed at the end of March 1946. The one constant that shines through the history of the ERTCs was that nothing remained the same for long. No organizational chart, no training method or schedule, no staff or cadre personnel, no trainees, no program, remained for more than a few months at either installation without modification, revision or abandonment for another solution. Meanwhile, new training programs were demanded, expanding the ERTC's role and responsibilities. As the war progressed into mid-1942 the demand for men increased for both basic troops and specialists. This problem was solved by developing a five week specialist training program within the 12 week training schedule. Men were chosen for this program based on their civilian skills and aptitudes as gleaned from their qualification cards. This naturally limited the number of blacks who qualified, for they often lacked basic educational skills and engineering backgrounds. Later, speciality programs included cooking school and driving school and more blacks qualified (Figure 2.1). But, of the 14,409 specialists that graduated from Forts Belvoir and Leonard Wood between June 1942 and June 1943, 10,486 were white. ${ }^{24}$

As the war progressed into 1943 the mobilization frenzy passed and ERTC cadre might have expected that they could settle into some manageable and refined training schedules. However, the manpower problem simply shifted to one of flow; that is, the demand for quantity subsided somewhat to be overcome by the problem of controlling the rate of incoming draftees and the disposition of outgoing graduates. At the local level, the training centers had only limited control and had to respond to each new demand from higher headquarters. Flow problems included constant quota changes, the need to cull from the ranks of Selective Service pools qualified recruits for specialist training, the inability of training center administration to control the manpower numbers being received from recruitment centers, and the backups in shipping-out trained soldiers to combat and service units. In many cases the solution to one problem was incompatible with another problem. Further, any single problem, or a combination of these problems, usually affected on-going training cycles. For instance, in 1943 the ERTCs changed to a 17 week training cycle, but this had to be phased-in because of on-going training. In addition to these difficulties, there was the constant robbing of qualified cadre to fill engineer units. Confusion like this continued until the war's end, and was simply the result of the Army's attempts to react to the war's rapidly changing front. The effect of these constant changes led Army engineer historians Coll, Keith and Rosenthal to conclude that by 1944 "basic military training at both Belvoir and Wood was badly disorganized."25 Records certainly support this conclusion, yet, given the circumstances, it is amazing how well the training centers did. Further, the bottom line for measuring their success or failure was the performance of their graduates (i.e., the performance of the Army Corps of Engineers overseas), and no one would conclude that it was anything less than extraordinary.

$\begin{array}{ll}{ }^{24} & \text { Ibid., p. } 251 . \\ 25 & \text { Ibid., p. } 268 .\end{array}$ 


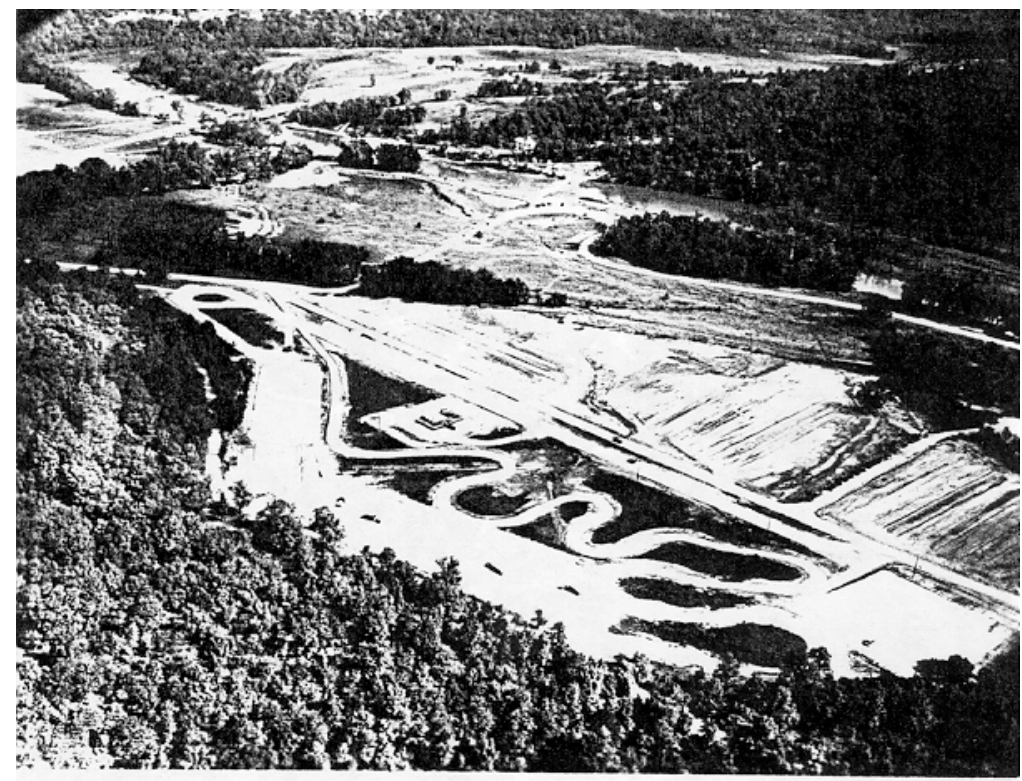

Figure 2.1 Motor Vehicle Driving Course at Fort Leonard Wood (OCMH Training of Replacements, Fillers).
In 1943 another change occurred in the ever-changing manpower problem. But this one had a more profound effect on Fort Leonard Wood than the others and was the direct result of institutional racial segregation. By that time in the war newly graduated basic engineer troops were no longer needed as unit fillers but rather as replacements for mounting battle casualties overseas. Army engineer policy had set the proportion of white and black engineer troops at three black soldiers for every seven

white soldiers. But black troops routinely were being used to fill service units, like Dump Truck and Labor units, or were trained as cooks and other similar specialties. Naturally, service units were not exposed to the casualty rates that combat units were experiencing. The result was that need for white replacements in white combat units rose, while the need for blacks in service units decreased or remained the same. Thus a surplus of black engineer soldiers developed by the summer of 1943 . Reducing the black population at all ERTCs would create housing and other facility problems (see Chapter IV), because white trainees might have to be housed with blacks. However, Fort Leonard Wood's cantonment had been designed with segregated facilities in mind. As a result they were "more widely separated from that of white trainees" and recreational facilities were considered comparable. Fort Leonard Wood then, could train all the black engineer soldiers needed and solve the facility problem at the other installations. Thus, beginning in August of 1943, all black men to be trained as engineer soldiers were sent to Fort Leonard Wood. ${ }^{26}$

\section{The Engineer Replacement Training Center--Army Services Forces Training Center At Fort Leonard} Wood

Fort Leonard Wood's Engineer Replacement Training Center began at Fort Belvoir, Virginia, in early 1941 while construction at the new Missouri post continued at a furious pace. Because Fort Belvoir already existed, it served as the best place to train the cadre and officers who would take charge in Missouri and offered the opportunity to develop some uniformity in the

\footnotetext{
${ }^{26}$ Ibid., p. 257; Colonel C. M. Hurtt, "The Role of Negro Service Units in Word War II," (Baltimore: Master's Thesis, Morgan State College, 1972), p. 8.
} 
training program soon to be conducted at both centers. ${ }^{27}$ The formation of Fort Leonard Wood's ERTC headquarters began taking shape as early as December 18, 1940 and on March 15, 1941, it was formally activated at Fort Belvoir. ${ }^{28}$ The next month Fort Leonard Wood's two engineer training group headquarters and detachments, the 6th and the 7th (Colored), were activated at Belvoir and moved to Fort Leonard Wood. At 12 noon on April 22, 1941, Fort Leonard Wood's ERTC was closed at Fort Belvoir and opened at 11:01 A.M. Central Standard Time at Fort Leonard Wood. Between that time and May 13, when the first 198 inductees arrived from a reception center at Fort Leavenworth, Kansas, the headquarters units of various companies planned and prepared for the tremendous challenge of training engineer soldiers. The first black inductees arrived on May 21, 1941.

\section{Organization}

Changing war needs placed a constant strain on the organization and staff of the ERTC throughout its five-year history. The challenges were numerous, and one of the first was finding enough experienced cadre. The total initial staff strength on June 1, 1941 was 290 officers and 1,418 enlisted. Thirty-two of these men came from the Regular Army, but in the following month experienced officers began to be posted to troop units and for the rest of the war the ERTC was staffed overwhelmingly by Reserve officers, recently commissioned officer candidates, and newly promoted noncommissioned cadre. Indeed from the beginning, only 128 of the initial cadre were Fort Belvoir's Instructor Course graduates before being posted to Fort Leonard Wood and most of the administration and paperwork routine had to be learned on the job. ${ }^{29}$ Another problem that strained the organization was the changing need in cadre specialties. For instance, in October 1942, staff was over strained by the addition of Specialist Schools (see below) and thankfully approval was gained to increase staff administration and instruction personnel (cadre) to 380 officers and 1,715 enlisted..$^{30}$ Then there was the problem of personnel quotas. Despite being over strained and taxed with both instructional and administrative duties, toward the latter part of the war, cuts began being made in staff strengths. It is clear that throughout the war Fort Leonard Wood's ERTC could have benefited from additional administrative staff and cadre. Yet oddly, in March 1944, a

${ }^{27}$ Office of the Chief of Military History, Training of Replacements, Fillers, and Cadres, Corps of Engineers, 6 March 1941-30 June 1944 (Washington D.C.: on file, CMH, ca. 1945) p. 2; Roberts, "The Engineer Replacement Center," p. 85. The primary source material for this section comes from the former document. ${ }^{28}$ Anonymous, "Note Cards Concerning the ASFTC, Fort Leonard Wood," (Fort Leonard Wood, Missouri: on file, History Office, U.S. Army Engineer Center, ca. 1946). This collection of note cards appear to have been taken by an historian (perhaps Dr. George H. McCune, Chief, Historical Section of the War Plans Division, Corps of Engineers) whose mission was to write a history of the Fort Leonard Wood training center sometime in 1945. See Letter, Colonel Joseph S. Gorlinski, War Plans Division, to Commanding General ERTC, 28 August 1944 (Fort Leonard Wood, Missouri: on file, History Office, U.S. Army Engineer Center). Although the cards (Standard Engineering Form 446), appear to reference the report in footnote 25, they may also actually be the original notes taken for the development of that report and another undiscovered report focused on Fort Leonard Wood's ERTC/ASFTC. For instance they contain more details than Training of Replacements and sometimes contradictory data. These cards focus on Fort Leonard Wood exclusively, while Training of Replacements covers forts Leonard Wood, Belvoir, and Camp Abbott.

${ }^{29}$ Anon., "Cards."

30 Coll, Keith, and Rosenthal, Troops and Equipment, p. 250. 
work load study of the Army Service Forces (ASF) indicated that while Fort Leonard Wood was ranked eighth (of 16 ASF centers) in efficiency, it was considered overstaffed! However, the ASF planned no staff reduction, recognizing the necessity for these additional personnel because of the higher number of "substandard" engineer trainees, or in other words, the fact that all black engineer soldiers were being trained at Fort Leonard Wood. ${ }^{31}$

The basic ERTC organization began with 10 training battalions divided into the 6 th and 7th Training Groups (Figures 2.2, 2.3, 2.4, 2.5). Initially, the authorized capacity at Fort Leonard Wood was 10,500 personnel. The center also included a Headquarters and Headquarters Company. The latter provided support for the center in the form of personnel, supply, training, drafting and a transport section. The 6th Group consisted of seven training battalions, the 26th through the 32nd, and the 7th Group (Colored), consisted of the 33rd through 36th. ${ }^{32}$ Each group also had its own Headquarters. Group Headquarters was responsible for supply, mess, recreation, and discipline, with only general responsibility for training. Each battalion consisted of approximately 1,000 men, usually with a Headquarters Company and training Companies A through D. Training was the main responsibility of the Battalion Headquarters. The 6th Group's battalions totaled 28 companies, and the 7th's, 12 companies. ${ }^{33}$ Plans were for each group to have its own service club, officers' messes, theaters and branch post exchanges.

Of course this initial organization lasted only a short time. For instance, in September 1942, three battalions of the 6th Group became the 8th Training Group, and the center added a Specialist Training Group consisting of two Specialist Development Companies, Officer's Training Courses, and Officer Candidate Preliminary Training Courses. Many headquarters functions were centralized. In February 1943, bands were attached to the 6th and 7th Groups, and the 8th Group added a Motor Company, the 409th Engineer Utilities Training Company and the 1049th Engineer Gas Training Company. Changing demands required another expansion of the administration in October 1943. The October 1943 reorganization added a WAC detachment to the Headquarters command, and a public relations section was added along with an Inspection Branch to oversee the quality of training. A Morale services branch and legal branches were added also. In 1944 there was yet another change, primarily a reorganization in who reported to whom, and the establishment of a unit training branch.

The most significant organizational change occurred on April 20, 1944 when the ERTC was redesignated as the Army Service Forces Training Center (ASFTC). Actually, the ERTC had been

31 Ibid., p. 266.

32 Anon., "Cards,"; "Souvenir Book Engineer Replacement Training Center, Fort Leonard Wood, Missouri," (Fort Leonard Wood, Missouri: on file, U.S. Army Engineer Museum); Charles J. Wolf Publishers, Fort Leonard Wood E.R.T.C. 1943 (St. Louis: Charles J. Wolf, 1943); Roberts, "Engineer Replacement Training Center," p. 85.

${ }^{33}$ Ralph S. Johansen, "Training a Selectee to be an Engineer Soldier," The Military Engineer, Vol. XXXIII, no. 188 (1941): 105. 


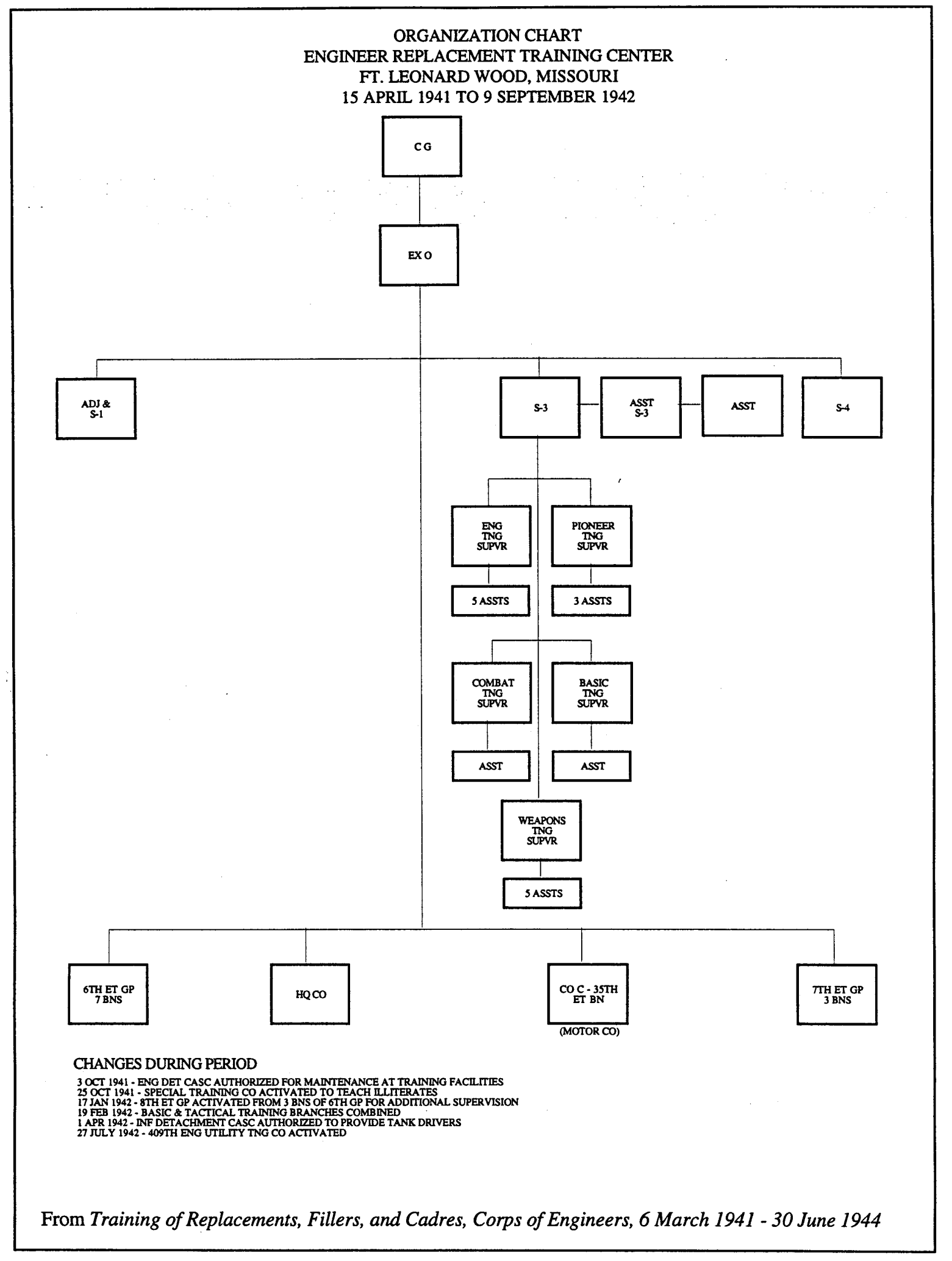

Figure 2.2 Organization, Fort Leonard Wood ERTC, 15 April 1941 to 9 September 1942. 


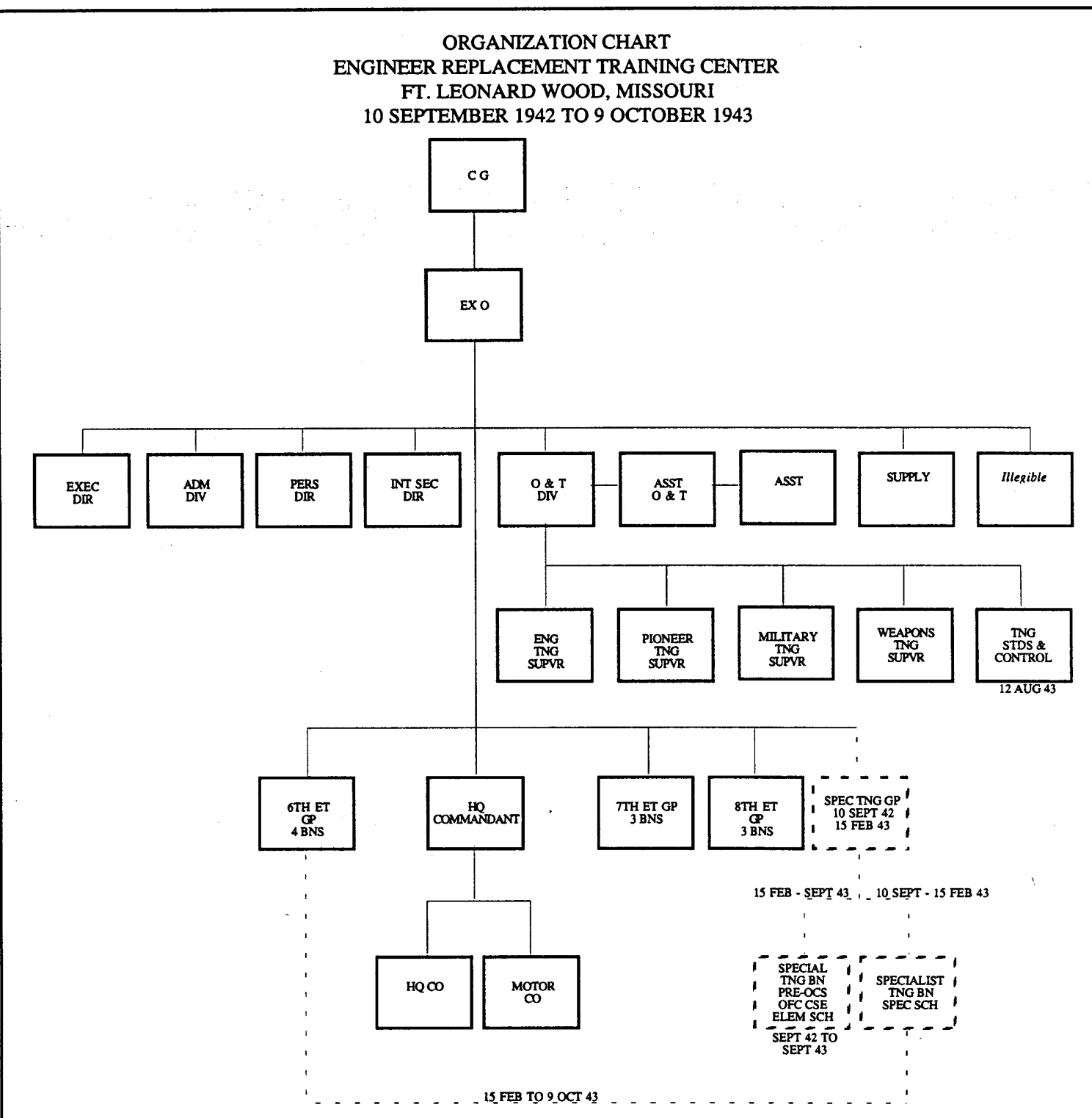

CHANGES DURING PERIOD

12 AUG 1943 TNG STDS \& CONTROL BRANCH ESTABLISHED

From Training of Replacements, Fillers, and Cadres, Corps of Engineers, 6 March 1941 - 30 June 1944

Figure 2.3 Organization, Fort Leonard Wood ERTC, 10 September 1942 to 9 October 1943. 


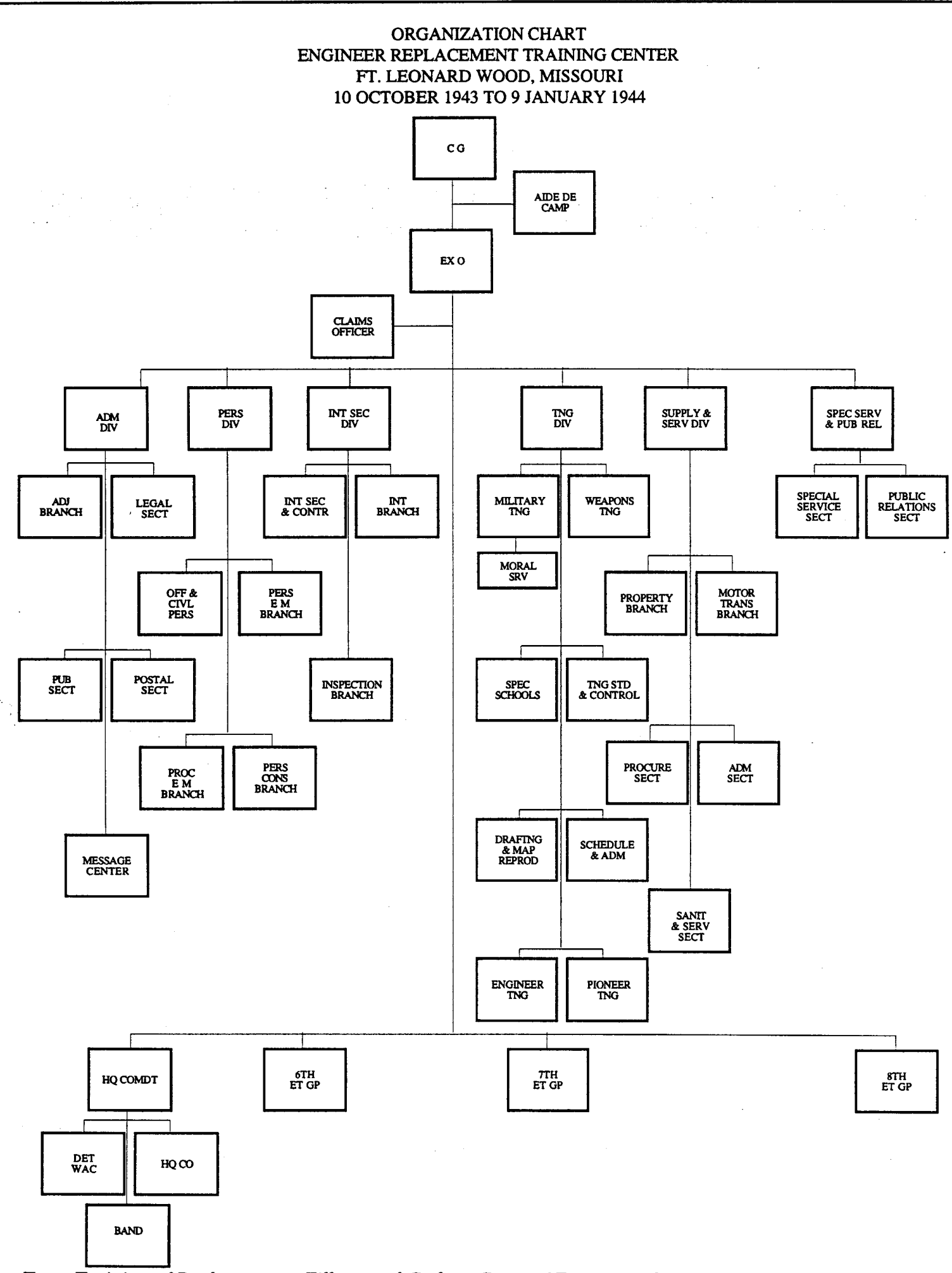

From Training of Replacements, Fillers, and Cadres, Corps of Engineers, 6 March 1941 - 30 June 1944

Figure 2.4 Organization, Fort Leonard Wood ERTC, 10 October 1943 to January 1944. 


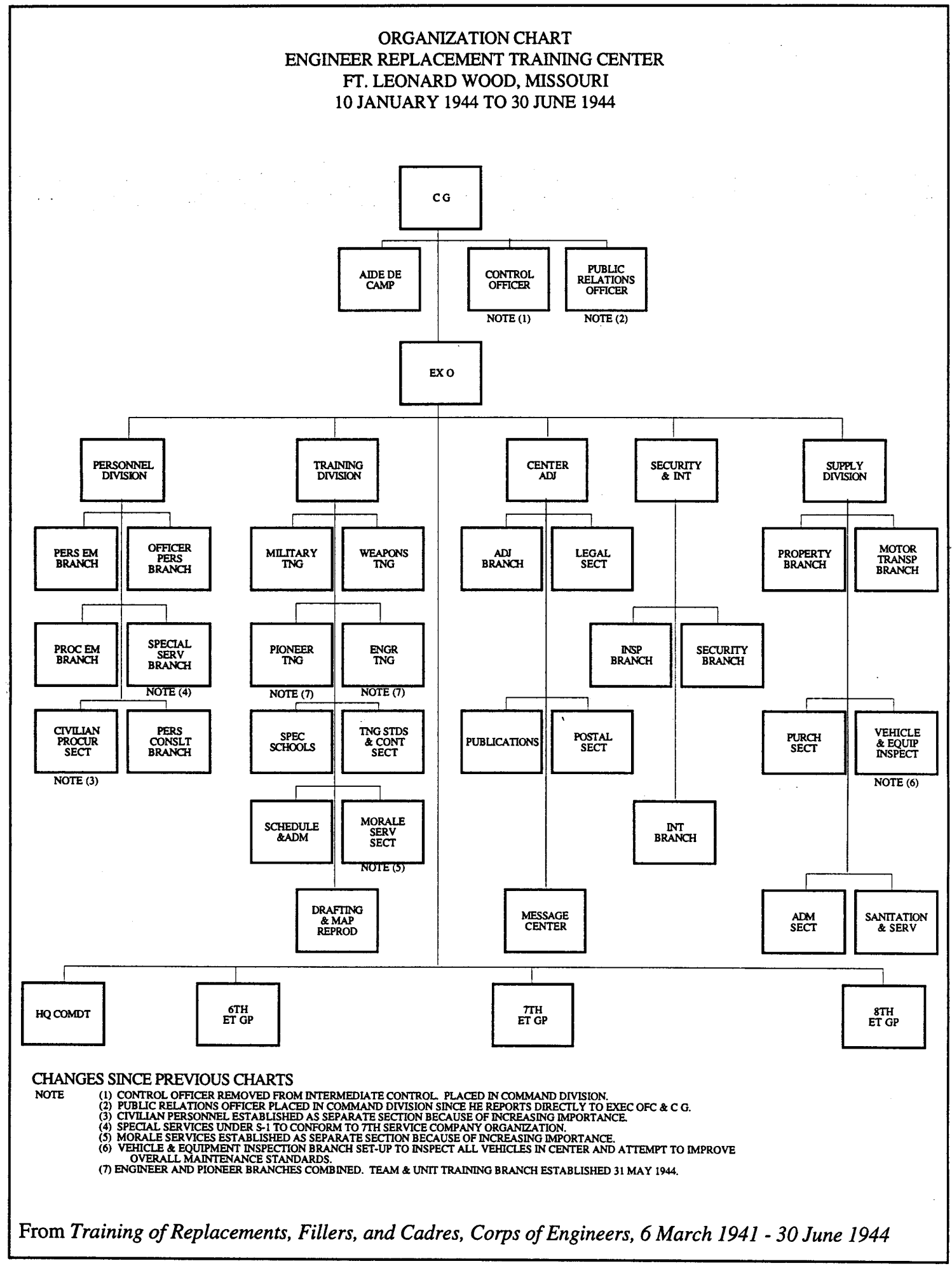

Figure 2.5 Organization, Fort Leonard Wood ERTC, 10 January 1944 to 30 June 1944. 
under administrative control of the Army's Service of Supply (SOS) since March 1942, and their name had been changed to the Army Service Forces (ASF) in March of $1943 .^{34}$ The ASF's purpose was to provide a wide variety of services to the Army Ground Forces including supply of food and clothing, procurement, technical training, military justice and, indeed, a thousand other things necessary to get the Army Ground Forces trained, fed, supplied, and moved. "An Army was inducted, armed, transported, supplied, and brought back again. .." and the ASF did it. ${ }^{35}$ Beyond the name change, the redesignation in 1944 brought a more fundamental change in responsibilities, in that both replacement and unit training were combined at Fort Leonard Wood. ${ }^{36}$ That is, Fort Leonard Wood was responsible for training replacements to fill active units, and also for training various units posted to the installation. This greatly expanded the role and scope of the former ERTC, increasing its technical training responsibilities.

The first commander of the ERTC was Brigadier General Ulysses S. Grant, III. General Grant was the grandson of the Civil War general and United States President and would later write a definitive biography of his grandfather. He was a career soldier and had been Secretary of the Supreme War Council at Versailles during WWI. His civilian career after the war was equally distinguished, including several leadership positions such as the first Vice President of George Washington University and President of the Columbia Historical Society. Having a life-long interest in planning and zoning in the Washington D.C. area, at the time of his death in 1968, he was a Trustee of the National Trust for Historic Preservation. ${ }^{37}$

General Grant had the responsibility of getting the Fort Leonard Wood ERTC up and running and left his mark on the center during his year of command. There are many indications that General Grant was a popular leader. He obviously had a keen interest in recreational facilities development for the soldiers as will be seen below. But several letters on file at the Historical Society of Washington D.C. also indicate that he went out of his way to help his immediate staff and the enlisted personnel under his command. In one unsolicited testimony, a friend writes to the general after meeting a new lieutenant who had served as a NCO at Fort Leonard Wood while Grant was ERTC commander. The new officer was asked what the troops thought about the General and the response was that "General Grant made that post" and that after Grant left, "nobody wanted to stay." ${ }^{138}$ Among this collection of letters is another from an officer thanking the General for "what you did for me," and yet another states that ". . it has become increasingly clear to me just how fine your attitude towards the men under your command

${ }^{34}$ For this reason, the text following uses "ERTC" and "ASFTC" interchangeably, depending on the sources cited.

${ }^{35}$ John D. Millett, The Organization and Role of the Army Service Forces, United States Army in World War II, (Washington D.C.: Office of the Chief of Military History, 1954), p. 2.

${ }^{36}$ Coll, Keith, and Rosenthal, Troops and Equipment, p. 315.

${ }^{37}$ James T. White Company, National Cyclopedia of American Biography, Volume 54 (Clifton, New Hersey: White Company, 1973), pp. 401-402.

${ }^{38}$ Letter, D. to General Grant, 17 January (no year), MS 344, U.S. Grant III Papers, Historical Society of Washington D.C. 
was and how much it contributed to their comforts, entertainment, and privileges." ${ }^{139}$ One can expect that all generals would have such letters in their files, but the informality of these letters, some in personal handwriting, appears to indicate that the General was respected, yet approachable.

On June 27th, 1942, General Grant was promoted by the War Department to the position of Chief of the Protection Branch of the Office of Civilian Defense and was relieved of command at Fort Leonard Wood. ${ }^{40}$ Colonel Frank S. Besson, already on the ERTC staff, assumed command. However, it is possible that his command was only in an acting capacity until either he would be promoted into official command or another commander named. In a biography of Frank Besson, he is not listed as having commanded the ERTC but rather was listed as being with the Development Branch of the Office of the Chief Engineer in 1942 and 1943. ${ }^{41}$ Furthermore, Colonel Besson wrote Grant a letter from Fort Leonard Wood on August 13, 1942, letting the General know that "I'm trying to keep the ball rolling along the alleys laid out by you." ${ }^{42}$ General Grant's August 18th response included the statement that:

[Brigadier General] Garlington fell on the stairs some time ago when starting out for his office in the morning and broke or misplaced a couple of vertebrae. I went to see him at Walter Reed Hospital and he seemed to think that he was likely to succeed me in command of the E.R.T.C.. . . If it is true I think it will be an outrage, but it will not be the first one. Of course you are my candidate for the job. ${ }^{43}$

So it is possible that the Army never promoted Besson to official command of the training center although he was acting in that capacity for some five months. ${ }^{44}$ In any case, General Grant's prediction was correct, for on January 20, 1943, General Creswell Garlington took command of the ERTC. Colonel Besson took command of the third ERTC, Camp Abbott, later that spring and as he had visited the camp in November 1942, it is probable that he was being groomed for the position while still in temporary command of Fort Leonard Wood's ERTC.

General Garlington commanded the Fort Leonard Wood ERTC / ASFTC from January 1943 until November 1944. At that time he retired from service, apparently from ill health, for he died on March 11, 1945. Tragically his son, an Army Air Force fighter pilot, had been reported missing in the summer of 1944. General Garlington was also a career engineer soldier and had attended the

\footnotetext{
${ }^{39}$ Letter, Officer Candidate Donald Gallagher to Grant, 4 October 1942; Letter, Lt. Col. John R. Baird to Grant, 4 September 1942; both, MS 344, U.S. Grant III Papers, Historical Society of Washington D.C.

40 Anon., "Cards."

${ }^{41}$ Marquis Who's Who, Vol. 1, 1974-1975 (Chicago: Marquis Who's Who' Company).

42 Letter, Colonel Frank S. Besson to U.S. Grant III, 13 August 1942, MS 344, U.S. Grant III Papers, Historical Society of Washington D.C.

${ }^{43}$ Letter, U.S. Grant III to Colonel Frank S. Besson, 18 August 1942, MS 344, U.S. Grant III Papers, Historical Society of Washington D.C..

${ }^{44}$ On the other hand a 22 January 1943 article in the Fort Wood News states that General Garlington assumed command from Colonel Besson.
} 
Command and General Staff School in 1925. During WWI he was with the 77th Engineers and earned both a Distinguished Service Cross and a Purple Heart. He is buried in Arlington Cemetery. ${ }^{45}$

Like Colonel Besson, Colonel E. G. Paules assumed temporary command until Brigadier General Dabney O. Elliott arrived to take command of the ASFTC after General Garlington. ${ }^{46}$ Colonel Paules had been on staff since the initial ERTC days. General Elliott was posted to Fort Leonard Wood from the War Plans Division of the Chief of Engineers, where he was Acting Chief. It is not clear as to whether General Elliott remained in command until the ASFTC closed or not.

\section{Training Programs}

At the ERTCs heart was the mission of training replacements, fillers, and later, engineer units. Formally, its job was "to train newly-inducted 'selectees' the subjects prescribed in Mobilization Training Program 5-1."47 But more simply, it was to take thousands of Selective Service draftees and rapidly turn them into soldiers first, with some rudimentary engineering skills second. From the ERTC they would be shipped to new engineer units as fillers and later to replace casualties in organized units. Mobilization Training Programs were the pre-war planned training regimes used for basic training. Naturally, the programs were based on previous war experience, specifically WWI. Program 5-1, the final draft completed in September 1940, called for a 12 week course in which there was a two week basic training period followed by seven weeks of technical training. In the final three weeks the soldier practiced his new skills within a team environment. The graduate was supposed to then go on to more specific unit training in more specialized arms and services. ${ }^{48}$ The planned training program was quickly revised. As noted earlier, the planned program was dropped for an eight week program in December 1941, before even a single building stood at Fort Leonard Wood. But the eight week program was simply far too little time and the ERTC's reverted back to a 12 week program by March 1942. This program remained in place until October 1943. With the manpower crunch easing, the center expanded to a 17 week program that included six weeks of basic, eight weeks of technical training, and three weeks of team training. "This system was the first to allow adequate training time." ${ }^{49}$

Whatever the program length, basic training was much like it is today, without the technical wizardry available to modern forces. Instructors, "experts," or at least a soldier

$\overline{45}$ Who Was Who in America, Vol. 2, 1943-1950 (Chicago: Marquis Company); "Lieut. Garlington Missing in Action," Fort Wood News, 23 June 1944; "Brigadier General Elliott New ASFTC Chief," The Fort Wood News, December 1944.

${ }^{46}$ See footnote 72, below; Letter, Brigadier General D. O. Elliott to Commanding General, 7th Service Command, ASF, Omaha, Nebraska, Subject: Request for Additional Housing, ASFTC, 28 April 1945, Record Group (RG) 160, File 600.02, National Archives, College Park, Maryland.

47 Anon., "Cards,"; OCMH, Training of Replacements, p. 1.

${ }^{48}$ Coll, Keith, and Rosenthal, Troops and Equipment, p. 125.

${ }^{49}$ OCMH, Training of Replacements, p. 10. 
Table 2.1 Fort Leonard Wood Training Schedule 1941

\begin{tabular}{|c|c|c|c|c|}
\hline BASIC TRAINING & HRS. TECH. TRAINING & HRS. & TACTICAL TRNG & HRS \\
\hline Battalion CO's Address & 0.5 Rifle Marksmanship & 51.25 & Scouting/Patrols & 7.5 \\
\hline Articles of War/Army Regulations & 2.5 Bayonet & 5.75 & Infantry Tactics & 26.25 \\
\hline Military Courtesy & 1.75 Hand Grenade & 2 & Night Ops./tactical & 4.25 \\
\hline Guard Duty & 3.75 Musketry & 11.75 & Air defense & 0 \\
\hline Sex Hygiene and Sanitation & 3.75 Anti-aircraft firing & 8 & Open Time & 45 \\
\hline First Aid & 3.75 .30 cal. machine gun & 8.5 & & \\
\hline Chemical Attack Defense & 5.75 Forts./camouflage & 22.5 & & \\
\hline Equipment Maintenance & 5.75 Basic equip. instr. & 11.25 & & \\
\hline Tent Drill and Equipment Display & 5.75 Bridges & 60 & & \\
\hline Marches and Camps & 23.75 Obstacles & 41.25 & & \\
\hline Close Order Drill & 26.75 Demolition & 30 & & \\
\hline Extended Order Drill & 9.5 Roads & 15 & & \\
\hline PT & 9 Gen. Construction & 15 & & \\
\hline Field Time & 3.75 Eng. Recon. & 14 & & \\
\hline \multirow[t]{2}{*}{ Inspections } & 22 Night Ops./technical & 8.5 & & \\
\hline & Rigging & 13.25 & & \\
\hline Basic Training Total & 128 Tech. Training Total & 318 & Tact. Train. Total & 83 \\
\hline TOTAL HOURS & 529 & & & \\
\hline
\end{tabular}

somewhat experienced in a particular skill, taught that skill to all trainees in each training cycle as the squads rotated through training areas. Field and class training techniques usually consisted of a demonstration by the instructor followed by the trainee attempting to copy the instructor. Field training followed classroom instruction. As much as possible, training was done at the squad level. Basic courses included physical training, military courtesy, hygiene, and of course, closeorder-drill, taught by officers and noncommissioned officers (Table 2.1). ${ }^{50}$ Technical training after basic included marksmanship, engineering skills, and general construction skills. The final training weeks were devoted to team field training, applying skills learned at the individual and small unit level. Combat training included squad and platoon, attack and defense. Trainees were subjected to gas, air, and mechanized attacks. Long route marches and night problems were scheduled. $^{51}$ Normally, the training day lasted eight hours, but with night problems and other military duties, trainees averaged a 54-hour week. A typical day began at 0600 with a bugle call, at 0610 roll was called and breakfast was served at 0635. At 0725, calisthenics, drill, and instruction started and continued until 1650. Dinner was at 1150 and supper followed immediately after the Retreat sounded at 1730. Taps was at 2300, and everyone was expected to be in their bunks, except on Saturdays when a bed-check occurred at $0100 .^{52}$

As noted, by the fall of 1942, the engineers needed not only basic troopers, but also men for special training. If the trainee was selected as a specialist trainee, technical training followed the

${ }_{50}$ Coll, Keith, and Rosenthal, Troops and Equipment, p. 164-165.

${ }^{51}$ Ibid., pp. 14-26.

52 Wolf Publishers, Fort Leonard Wood E.R.T.C., Foreword. 
basic military instruction course. Otherwise, the trainee was sent to pioneer training. Specialist training at the ERTCs graduated cooks, mess sergeants, supply sergeants, company clerks, chauffeurs, motor vehicle (truck) operators, carpenters, construction machinery operators, demolitions men, bakers, and buglers. ${ }^{53}$ Also, some men were sent to the Signal Corps or other service units for specialist training. Specialist training at Fort Leonard Wood began with a cook and mess sergeant school and soon expanded to include company clerks, chauffeurs, and machine woodworkers. Fort Leonard Wood also trained men as sawmill operators, plumbers and pipe fitters, and sign painters. ${ }^{54}$ By 1944 , some $80 \%$ of trainees were in specialist training.

In the Spring of 1944, Fort Leonard Wood found itself responsible for not only replacement and filler training, but also for unit training. This required some adjustment in the training regime. For the first 14 weeks, basic and technical training remained the same. With some exceptions, after basic and technical training the soldier was assigned either as a loss replacement and was sent to a provisional unit for field training, or he was assigned to a newly activated unit and they "rehear[sed] their role as an officially-designated Engineer Unit." ${ }^{55}$ This change was a result of U.S. Army Engineer needs and reorganization as Army Service Forces Training Centers. One additional change resulting from reorganization as the ASFTC was that, beginning in October 1944, training was reorganized as "phased training." This meant that battalions were no longer responsible for the entire training cycle, from basic to team training. Rather, certain battalions handled basic only, others handled technical training only, and so on. Soldiers passed from one battalion to another as they advanced through training. This allowed better instructor specialization, and helped to alleviate the continuing problem of insufficient training aids, which was a constant issue at Fort Leonard Wood's ERTC/ASFTC. Also, by that time lessons learned on the European front were incorporated into course content. Furthermore, in 1944 most engineer troops were bound for the Pacific Theater, so appropriate short courses, like malaria prevention and control, were added to the training schedule. For the same reason, first aid courses devoted time to the prevention of tropical diseases and field operations were modified to prepare the trainee for jungle fighting, close combat, and night operations that were expected in the Pacific Theater. ${ }^{56}$

At the beginning of 1945, the rapidly changing war again caused revisions in the ASFTC training program. From this point on, the ASFTC had to deal with men who had served overseas, or at other U.S. installations, and were in the process of redeployment. Most of these men had graduated from basic training, but needed refresher courses, or were deficient in one area and required additional training. At Fort Leonard Wood, a Training Evaluation Branch was created in March. This branch was charged with the responsibility of evaluating incoming "Zone of Interior" and redeployment personnel, and based on this evaluation, fit the men into specialties suited to

\footnotetext{
53 Ibid., p. 18; Coll, Keith, and Rosenthal, Troops and Equipment, p. 247.

54 "Annex I, Flow of Trainees," in OCMH, Training of Replacements, p. xiv.

55 Office of the Chief of Military History, Training of Replacements, Fillers, and Cadres, Corps of Engineers, 1 July 1944-31 December 1944 (on file, Washington D.C.: CMH, ca. 1945), p. 2.

${ }^{56}$ OCMH, Training, 1 July 1944-31 December 1944, p. 13.
} 
their individual aptitudes and experience. At the same time the ASFTC continued to meet War Department needs. Unit and Team training programs were combined, and the training center added various sections like a "Parts and Evaluation Section" and a "Preparation for Overseas Movement Section." The former section was needed because of the increase in the number of Engineer Dump Truck Companies beginning training at Fort Leonard Wood. ${ }^{57}$

On August 10, 1945, the Japanese surrendered and suddenly all the frustrations of changing training schedules, quotas, flow, housing, and inspections came to a halt. Army engineers recognized a continuing need for experienced troops and specialists in the post-war Army, but such considerations were swept away by the strong tides of rapid demobilization. Between planning and executing demobilization, and planning what might be needed in a peacetime army, the only thing not in flux was the pace of change. At Fort Leonard Wood commanders awaited the letter or call that would advise them of the fate of the installation's ASFTC while attempting to maintain some level of morale among the men in their 17-week training program. But the entire wartime atmosphere and drive was rapidly dissolving. Basic training was increased to nine weeks and team training was omitted. Training schedules were reduced to 20 hour weeks and legal holidays were observed once again. Phased training was discontinued and training companies were formed once again whereby the trainee stayed with a single company throughout basic and technical training. Unit training continued, but as personnel were discharged and training units shrank in size they were consolidated. Planning for civilian work and the Strategic Reserve programs was initiated. Field exercises were reduced across the board for all redeployed units. ${ }^{58}$ Mostly, though, the men simply wanted to go home. With victory proclaimed "The 'war's-over-attitude' had a negative affect on the on-going troop training." ${ }^{15}$

\section{Training Challenges}

Throughout the ERTC/ASFTC's five-year life, commanders and cadre struggled with several on-going problems besides meeting the War Department's changing needs and schedules. At the installation level, the centers also struggled with the lack of experienced cadre, a lack of training aids, and the quality of the selectees entering the U.S. Army Engineers.

The problem of finding trained instructors, after the initial experienced staff was quickly pulled away for other assignments, was never really solved. A Fort Leonard Wood "Initial Progress Report" concluded that the shortage of officers and cadre (both officers and NCOs) was the most

\footnotetext{
${ }^{57}$ Office of the Chief of Military History, Training of Replacements, Fillers, and Cadres, Corps of Engineers, 1 January 1945-30 June 1945 (Washington D.C.: on file, CMH, ca. 1945), pp. 1, 4-5.

${ }^{58}$ Office of the Chief of Military History, Unit Training in the Corps of Engineers, 1 July 1945-31 December 1945 (on file, Washington D.C.: on file, CMH, ca. 1945), pp. 1-2.

${ }^{59}$ Office of the Chief of Military History, Training of Replacements, Fillers, and Cadres, Corps of Engineers, 1 July 1945 1945-31 December 1945 (Washington D.C.: on file CMH, ca. 1945), pp. 3-9.
} 
serious problem hindering the conduct of training. ${ }^{60}$ Cadre did improve somewhat as inadequate instructors were transferred, top graduating trainees were retained as cadre, and the ERTC fought to retain its few experienced teachers. Still, according to a 1945 report, a major factor limiting training at that time was the shortage of experienced officers in the ASFTC, primarily due to demobilization. ${ }^{61}$ In a related problem, black cadre and support staff to work in the 7 th Group (Colored) were desired and actively sought out by the ERTC command from the beginning. However, Army quotas made filling these slots difficult. Early in 1941, the Fort Leonard Wood ERTC requested 33 qualified "colored" men to serve as cooks, bakers, typists, clerks and other specialities. However, the Seventh Army Corps responded that it had already inducted the majority of the black personnel it was allotted, and from the remainder, Headquarters felt that it would not be able to find 33 qualified men. ${ }^{62}$

The lack of quality training aids, and their limited number, was an especially bothersome problem at Fort Leonard Wood at the beginning of the war. Manuals, film strips, and films were scarce, inadequate, and out of date. ${ }^{63}$ Training aids were practically nonexistent, and to exacerbate the situation, Seventh Corps Area Headquarters actually "forbade local purchase or procurement of training aids such as posters or commercial fireworks." ${ }^{164}$ The reason for this order probably was to maintain training aid standardization. However, while awaiting training aids from headquarters, training had to go on, so the order simply made teaching more difficult as each center solved the immediate problem locally. Fort Belvoir, Virginia, eventually set up a separate section to construct training aids and Fort Leonard Wood and Camp Abbott followed Belvoir's lead. Full scale models, cut-away models, signboards, posters, and charts slowly became part of the instructional program. By 1944 the ASFTC at Fort Leonard Wood had solved the problem by devising some very innovative training aids. At that time they unveiled a revolving stage with spotlights and message boards which was used to demonstrate camouflage and concealment. The center also built a tower in the Big Piney River for training on a debarkation net. The men were required to climb down the net onto pontoon boats, simulating debarkation from transport ships. Another innovation was a rigging obstacle course in which the trainees were required to use their newly acquired knowledge of knot tying and lashing to successfully traverse the course. ${ }^{65}$ Finally, in 1945, Fort Leonard Wood's ASFTC developed a series of skits to demonstrate instructional methods for course instructors. ${ }^{66}$ These training devices provided some variety in the training regime, but throughout the war it was mostly learning by doing for trainees.

\footnotetext{
${ }^{60}$ OCMH, , Training of Replacements, 6 March 1941-30 June 1944, p. 11.

${ }^{61}$ OCMH, Training of Replacements, 1 July 1945-31 December 1945, p. 9.

${ }^{62}$ Letter, Lt. Colonel Fred W. Miller, Headquarters, Seventh Army Corps to L.t Colonel Daniel Noce, ERTC (7th Group) 19 March 1941 (Fort Leonard Wood, Missouri: on file, History Office, U.S. Army Engineer Center).

${ }_{63}$ OCMH, Training of Replacements, 6 March 1941-30 June 1944, p. 7.

${ }^{64}$ Roberts, "The Engineer Replacement Training Center," p. 88.

${ }_{65}^{65}$ Memorandum, Inspection of the ASFTC," Colonel Malcolm E. Craig, 12 June 1944, (Fort Leonard Wood, Missouri: on file, History Office, U.S. Army Engineer Center).

${ }^{66}$ OCMH, Training of Replacements, 1 January 1945-30 June 1945, p. 11.
} 


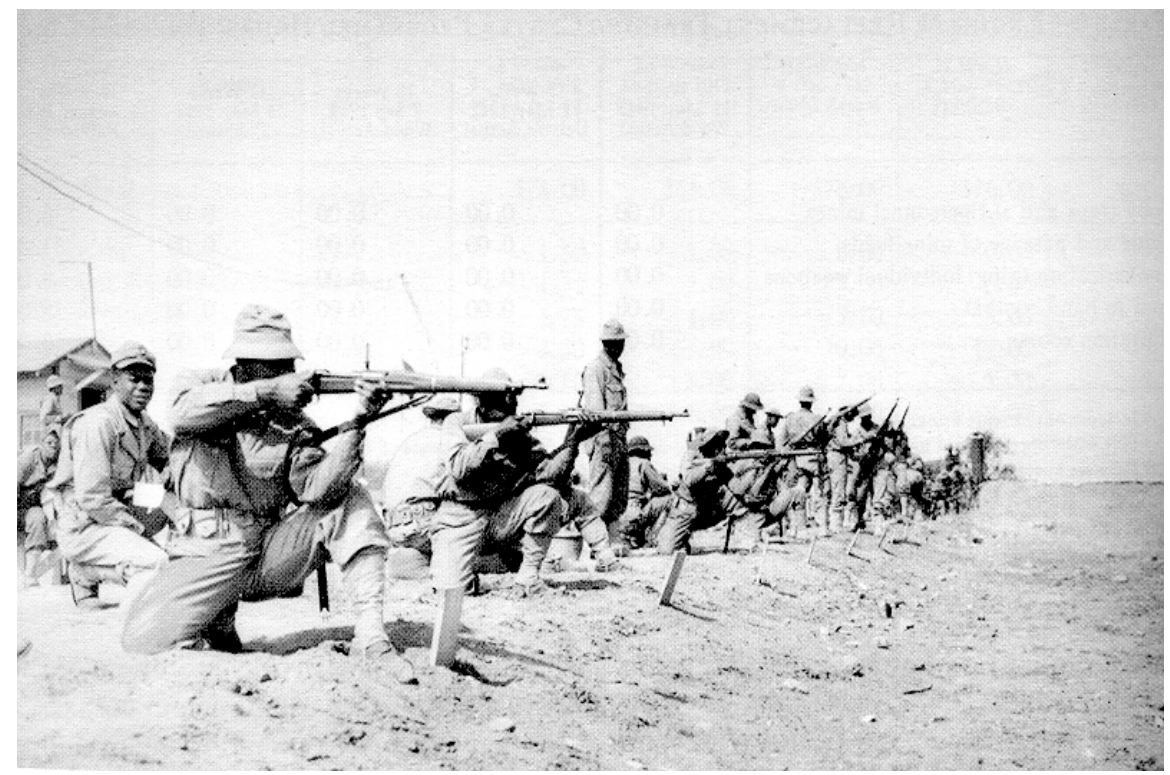

Figure 2.6 Black Soldiers on the Firing Line With Old Springfields,
Given the instant demand for manpower and the methods used in the Selective Service process, it was not surprising that the engineer training centers did not always get quality engineering candidates. Further, given years of Jim Crow treatment in both civilian and military society, it should not be surprising that many Fort Leonard Wood (Coll, Keith, and Rosenthal, Troops and Equipment, p. 170). black draftees had had no opportunity to gain the basic skills necessary to operate successfully as a soldier, including basic reading and writing. Thus the ERTCs were immediately faced with the problem of turning illiterates into soldiers. In September, 1941, Fort Leonard Wood established an elementary school to meet this challenge. ${ }^{67}$ Then in October, a Special Training Battalion (as opposed to Specialist Training) was assigned to ERTC Headquarters to administer development training for poorly educated enlisted men. As the program developed, trainees began in the regular training routine and after a two week observation, men needing special instruction were referred to the special training unit. At Fort Leonard Wood they could spend as much as eight weeks in special training learning such things as elementary reading and writing. A psychiatrist was assigned both at Fort Belvoir and Fort Leonard Wood to assist in this selection process. The program was surprisingly successful and many men were brought to the equivalent of a fourth grade education. Overall, about $11.7 \%$ of black trainees and $1.7 \%$ of white trainees were sent to this program. ${ }^{68}$

Another problem that occurred with the trainees, again a larger problem with African Americans, was in marksmanship qualifying. The Directorate of Training demanded and continued to press for better marksmanship, or at least the standard set by their standard operating procedures (Figures 2.6, 2.7). The standard demanded that $80 \%$ of the men in any unit would qualify. But at Fort Belvoir, white troops did not meet this standard until December 1942 (81\%), and it was not met at all by either whites or blacks at Fort Leonard Wood that entire year. ${ }^{69}$ That December, an especially bad score prompted Colonel Frank Besson to write to the Chief of Engineers, Washington: "I feel very deeply the disgrace of this marksmanship score made by the 67 Anon., "Cards."

68 OCMH, Training of Replacements, 6 March 1941-30 June 1944, p. 12; Coll, Keith, and Rosenthal, Troops and Equipment, p. 165.

69 Coll, Keith, and Rosenthal, Troops and Equipment, p. 171. 
34th Battalion. To correct the situation I am making drastic changes." ${ }^{170}$ Indeed, Colonel Besson acted promptly and in January 1943, 48 white expert coaches were gathered at Fort Leonard Wood and assigned the task of training both black and white slow learners. The 33rd Training Battalion of the 7 th Group set up a 600 inch practice range beneath a platoon barracks, and using .22 caliber rifles, got in extra training at night. ${ }^{71}$ To add incentive, the Weapons Training Officer suggested that a banner be

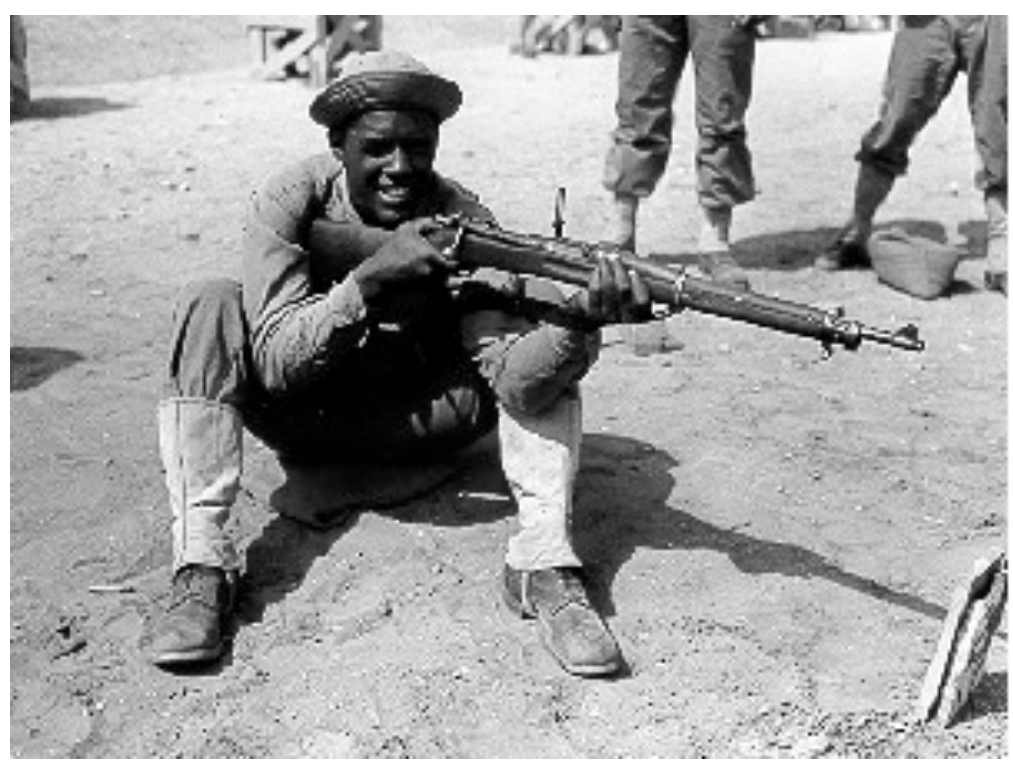

Figure 2.7 Pvt. Fred Pollard, Rifle Range Instructor, Fort Leonard Wood, 1942 (courtesy, History Office, U.S. Army Engineer Center). given to any white company that qualified above $80 \%$ and any black company that qualified over $45 \%$. These efforts paid-off, at least for a while. White enlisted qualifying rose from $72.71 \%$ in December to $89.38 \%$ in February 1943. Meanwhile black qualifying soared from 15\% to $61.84 \%$, still not good enough but a major improvement. ${ }^{72}$ Later that year, in July, whites were qualifying at 98.16\% while blacks had climbed to $81.85 \%$. $^{73}$ The following year an inspection of the ASFTC gave high praise to the center's marksmanship training. Instruction, coaches, range discipline and firing records were all rated excellent, with the average qualification for the center being $95.5 \%$ and the lowest was a black battalion at $86.9 \%{ }^{74}$ In a memorandum dated November 24, 1944, the ERTC proudly announced that on a dull, chilly windy Thanksgiving Day, a black company qualified at $84.8 \%$. "This is the best firing record to date of any colored troops at this center, prior to refiring." ${ }^{175}$ Perhaps that November was the high point in Marksmanship training, for the following July 1945, Deputy Commander E. G. Paules wrote to the commanding officers of the 7th and 8th training groups that he had observed incorrect firing positions. He recommended a series of changes in the way

\footnotetext{
${ }^{70}$ Letter to Brigadier General Clarence L. Sturdevant, 21 December 1942 (Fort Leonard Wood, Missouri: on file, History Office, U.S. Army Engineer Center).

71 "33rd Sets Up Range Beneath Barracks," The Fort Wood News, 22 January 1943 (Carlisle Barracks, Carlisle Pennsylvania: microfilm, on file, U.S Military History Institute).

${ }^{72}$ Memorandum from Capt. McNath to the Commanding Officer, ERTC, Fort Leonard Wood, 13 January 1943 and Memorandum to Chief of Engineers, Washington, from ERTC, Fort Leonard Wood (Fort Leonard Wood, Missouri: both on file, History Office, U.S. Army Engineer Center).

${ }_{73}$ Memorandum, "Small Arms Record Firing," 4 August 1943 (Fort Leonard Wood, Missouri, both on file, History Office, U.S. Army Engineer Center).

${ }^{74}$ Colonel Craig, "Inspection."

${ }^{75}$ Memorandum, E.G. Paules, to Colonels Charles Hinton and S. Whipple, Seventh Services Command, and Lt. Colonel Hoskins and Maxwell, ASF Washington, 24 November 1944; "Memorandum For the Director of Military Training," ASF, E.G. Paules, 14 November 1944 (Fort Leonard Wood, Missouri: both on file, History Office, U.S. Army Engineer Center).
} 
rifle marksmanship was taught on the firing line. ${ }^{76}$ Importantly, the memo demonstrates that the marksmanship problem did not wholly lay at the feet of the trainees. In fact, good instructors were a large part of the problem. Furthermore, during that first year at Fort Leonard Wood when no unit qualified, trainees coped with inadequate facilities and equipment. When it opened, the installation only had one 300-yard firing range to share among thousands of trainees. Furthermore, the modern M1 Garand did not get to the centers until December of 1942, and training was conducted up until that time using worn-out Springfields, which were in low supply anyway. Trainees had to share weapons, which meant that every time a soldier practiced he had to re-zero his rifle. As soon as the trainees qualified for record, their rifles were assigned to other units and practice ceased.

\section{Officer Training}

The rapidly expanding engineer army needed both quality soldiers and quality officers and as in most Army branches at the war's beginning, officers were scarce. Before the war, quality engineer officers were developed slowly, usually beginning with two years commanding troops, then one year of civil schooling followed by nine months at the engineer school, and finally two years of harbor duty. This simply wasn't going to happen in wartime. By 1942 the scarcity of officers was critical enough to require the ERTC's to take on yet another training challenge, that being the additional instruction of new engineer officers and refresher courses, and the preparation of officer candidates. Fort Leonard Wood established an Officer Candidate Preparatory School on January 5, 1942, and Special Officers Training Courses on the 16th. The Special courses began as six-week programs but, like enlisted training, were quickly reduced due to the demand for officers. The second class became a five week course and then it was reduced to a two week course. Meanwhile, another special class for railroad officers was started. Eventually, by the eighth class the program settled on a four week program that continued until May 1943. The course objectives for these officers were first for officers to learn their basic duties, and then learn to train a unit. The original six-week program had some 300 hours of instruction in administration, leadership, training methods, weapons, tactics, and engineering, and then the officers spent 102 hours in training units as on-the-job experience. ${ }^{77}$ The completion rate for these classes was very low, due primarily to officers being pulled from the classroom for assignments as instructors at the ERTC. Of the 1,185 officers that attended, only $60 \%$ were listed as having completed the course. While standards for completion were considered high, the high failure rate was due to officers missing classes rather than test failures. There were no tests and no officer was rated unsatisfactory. ${ }^{78}$

\footnotetext{
${ }^{76}$ Memorandum, "To Commanding Officers, 7th ET Group and 8th ET Group," from Colonel E.G. Paules, 20 July 1945 (Fort Leonard Wood, Missouri: on file, History Office, U.S. Army Engineer Center).

${ }^{77}$ Lt. Colonel Henry C. Wolfe,"Memorandum No. 4, Officer Training Courses," (Fort Leonard Wood, Missouri: on file, History Office, U.S. Army Engineer Center); Roberts, "The Engineer Replacement Training Center," p. 91; Anon., "Cards."

${ }^{78}$ Lt. Colonel Wilbur T. Edwards, Jr., "History of Officer Training," 20 December 1944 (Fort Leonard Wood, Missouri: on file, History Office, U.S. Army Engineer Center).
} 
Although Special courses were discontinued in 1943, sometime after that, probably in 1944, an Engineer Officer Replacement Training Pool (EORP) was created to provide a pool of officers (both black and white) in case of demand and also as a place for officers to receive additional training while awaiting reassignment. At Fort Leonard Wood an influx of experienced officers from overseas and a surplus of recently trained officers created a situation where the ASFTC had to create a separate EORP School. This program continued until at least June of 1945 with some modifications and was

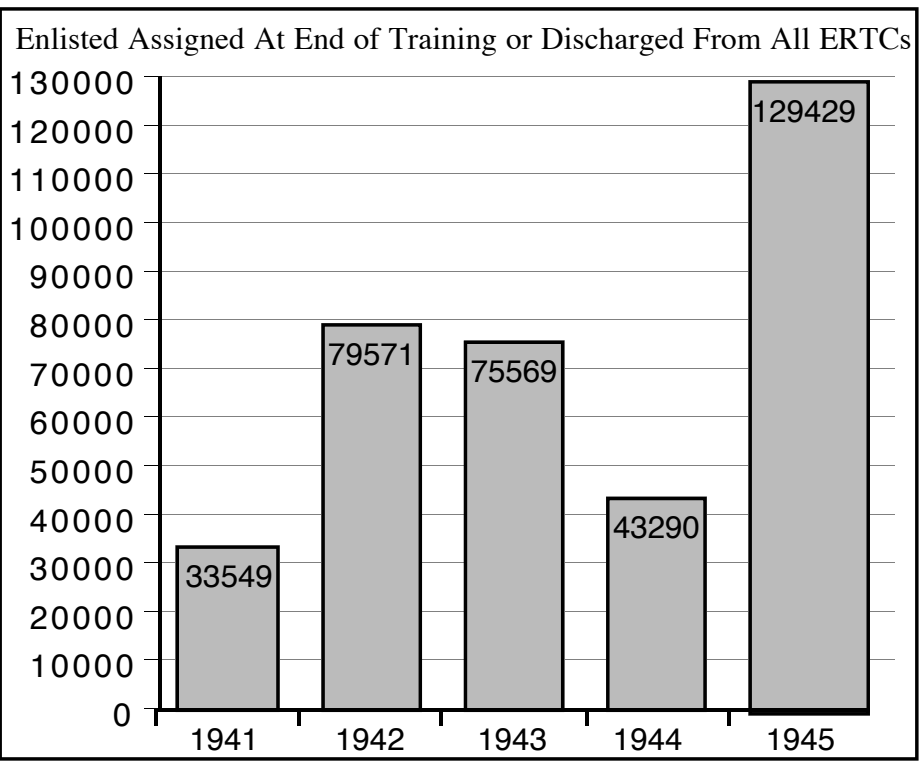

Figure 2.8 Enlisted Assigned or Discharged From All ERTCs (From Training of Replacements, Fillers). quite similar in scope and outcome to the Special Officer Courses of 1942. The school's mission, although in reality it was merely a way station for officers awaiting reassignment, was to improve their military education, review military subjects, solve engineering problems, and "participate in lectures and discussions based upon actual experience in overseas theaters of operations." As if the teaching challenges were not enough, the instructors in this course had to deal with officers coming and going constantly without completing the program, as they were being assigned overseas, returning from overseas, or going to training units. If the officers completed the course without assignment, some were channeled to a Basic Instructor's Course and soon used as instructors. Some of the subjects taught in this course were, "Camouflage," "Command of Negro Troops," and "Command Administration. ${ }^{79}$

\section{Output}

Despite the problems and challenges of rapidly turning civilians into soldiers, the ERTC at Fort Leonard Wood churned out engineer soldiers by the thousands. It is impossible to know how many men passed through the ERTC course at Fort Leonard Wood during the war because after July 1944, manpower totals were combined with the other ERTCs. However, in 1941, Fort Leonard Wood received 17,324 men and 14,385 were "shipped." In 1942 these figures were 45,028 and 39,208 respectively, and in 1943 they were 16,777 and 10,327, respectively.$^{80}$ Overall, 259,386 men

${ }^{79}$ OCMH, The Schooling of Commissioned Officers by the Corps of Engineers 1 July 1944-31 December 1944, (Washington D.C.: on file, CMH, ca. 1946), p. 22-24; OCMH, The Schooling of Commissioned Officers by the Corps of Engineers 1 January 1945-30 June 1945, (Washington D.C.: on file, CMH, ca. 1946), p. 25-34.

80 "Section 1, History of Center," Anon. "Cards," (Fort Leonard Wood, Missouri: on file, History Office, U.S. Army Engineer Center). 


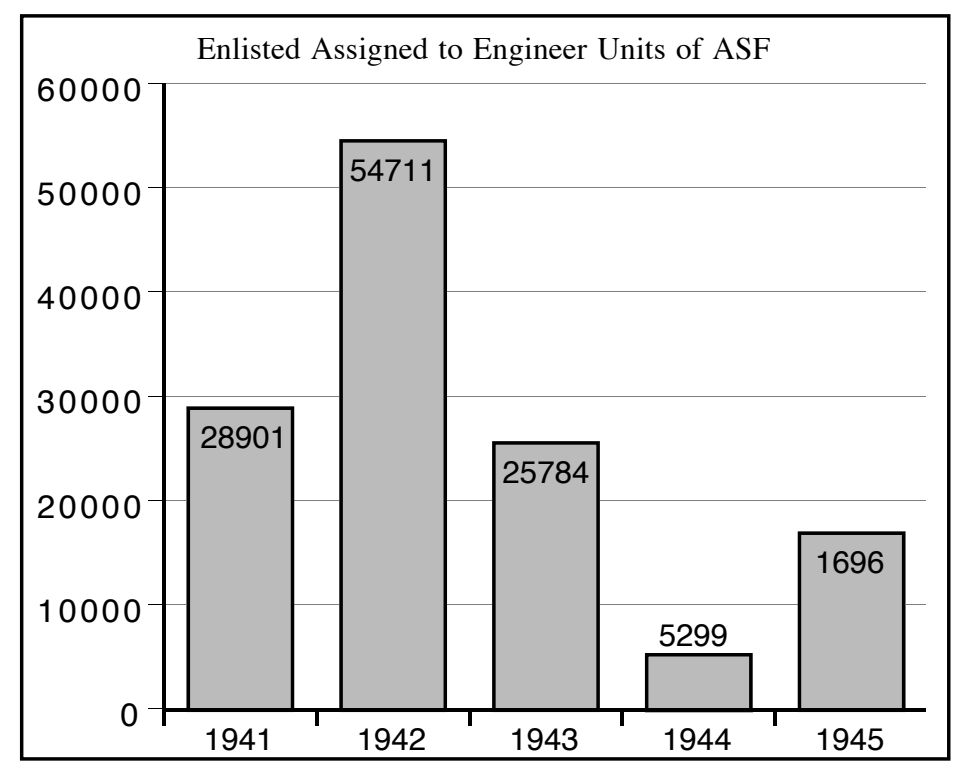

Figure 2.9 Enlisted Assigned to Engineer Units of ASF (From Training of Replacements, Fillers). graduated and were assigned at the end of training from all three ERTCs (Figure 2.8). ${ }^{81}$ Another 52,987 were discharged from the Army or died while in training. From 1941 to 1943 the majority filled engineer units in the ASF or other commands; 109,396 were assigned to Engineer Units, another 6,786 assigned to other engineer units, and some 25,353 to Specialist Schools (Figures 2.9, 2.10, 2.11). From 1944 on, the majority were shipped out as replacements (Figure 2.12). Throughout the period, the ERTCs sent 7,454 to Officer Candidate School (Figure 2.13).

\section{Race Relations at Fort Leonard Wood}

During WWII black soldiers at Fort Leonard Wood experienced the same challenges and prejudices that black soldiers faced at other installations. They met the same barriers to opportunity, the same mixture of racial bias and acceptance from white officers, and they were evaluated in the same way. Fort Leonard Wood received a wide cross-section of black and white men and women for training from across the nation, although it appears that the installation received a larger number of blacks from the southern states than the northern states. There were no major racial incidents, such as riots, drawing national attention to Fort Leonard Wood, but the were a number of recorded minor incidents that indicate racial tensions were part of everyday life on post. Thus the WWII experiences of blacks at Fort Leonard Wood stand as a microcosm of the racial problems present in all levels of American society, civil and military in the mid-twentieth century. Added to this was the strain of a massive bureaucracy attempting to organize, train, and ship large numbers of men and women for war.

Locally, the resistance to black military personnel at Fort Leonard Wood began before the installation was opened. Brigadier General George V. Strong, of the Seventh Corps Area, sent a letter to the Adjutant General in Washington D.C. in February 1941, protesting the planned stationing of 3,000 black ERTC men and 2,000 other black troops at the installation. General Strong's concerns were that the local populous was "distinctly white," and that there was

\footnotetext{
${ }^{81}$ For comparative purposes, Fort Leonard Wood's total strength, both ERTC/ASFTC and Army Ground Forces (AGF) as of 30 June of each year was as follows: 1941--40,000, 1942--33,039, 1943--41,557, 1944--37,636, 1945--18,231, 1946--38; "Fort Leonard Wood," (Washington D.C.: Vertical files, OCMH).
} 
"outspoken antipathy" towards blacks regionally. Further, since there was no local black population, the general pointed out that there would be no social and recreational support from the local community, and no black community infrastructure in place when black troops arrived. He recommended that all black engineer soldiers be trained at Fort Belvoir, Virginia. ${ }^{82}$ Obviously, the general's recommendations were ignored, and regardless of whether the general was acting in what he thought were the

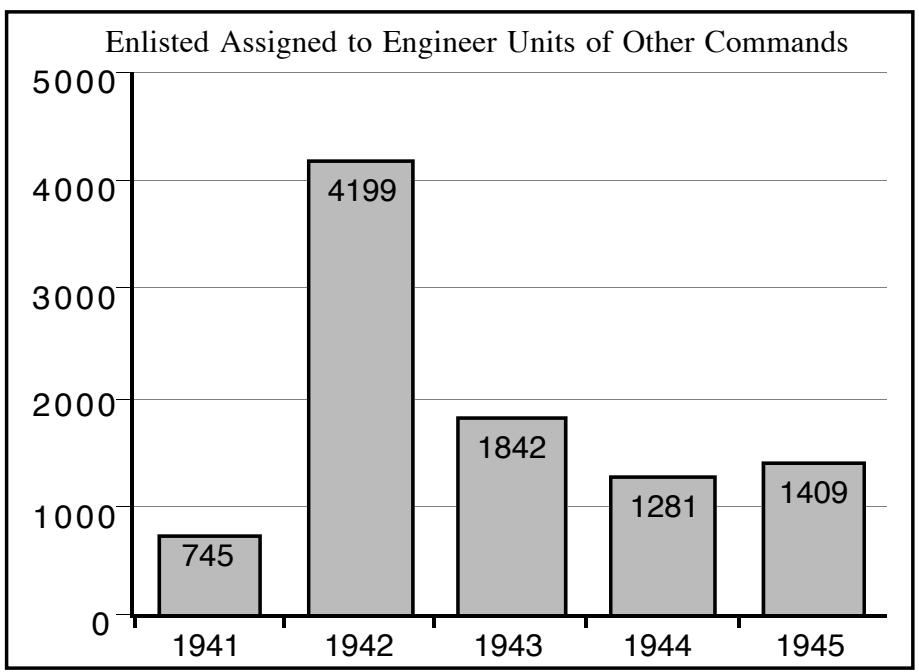

Figure 2.10 Enlisted Assigned to Engineer Units of Other Commands (From Training of Replacements, Fillers). best interests of blacks or from a personal prejudice, his statements were true. The regional population surrounding Fort Leonard Wood was overwhelmingly white and rural and had been historically. The 1940 Pulaski County

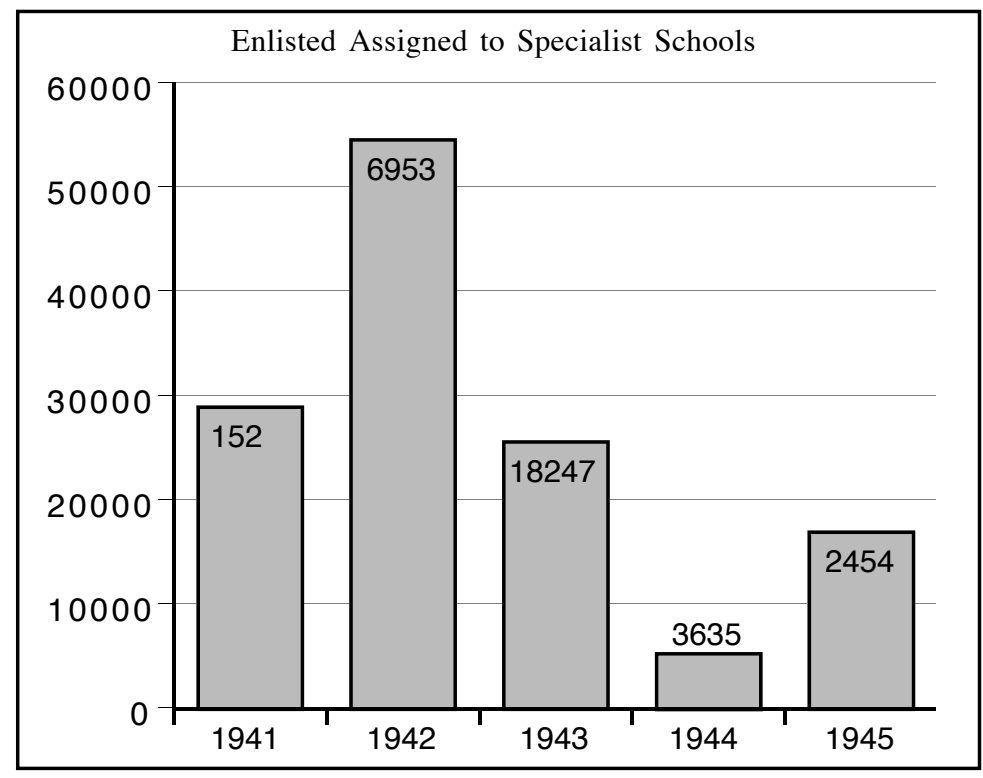

Figure 2.11 Enlisted Assigned to Specialist Schools (From Training of Replacements, Fillers). population statistics indicated that there were only three blacks (probably a single family) living in the entire county encompassing the new installation. ${ }^{83}$ The nearest large black populations that might offer a lonely soldier support were as far away as St. Louis and Springfield. The closest town with any appreciable black population was Jefferson City, Missouri, some 75 miles away over poor roads. Before black and white civic groups began sponsoring trips to St. Louis, a black soldier might spend as much as $\$ 5.00$ in transportation costs to get to and from St. Louis or Kansas City. ${ }^{84}$

${ }_{82}$ Letter, Brigadier General George V . Strong to The Adjutant General, "Colored Troops at Fort Leonard Wood," 25, February 1941, (Fort Leonard Wood, Missouri: on file, History Office, U.S. Army Engineer Center).

${ }_{83}$ Steven D. Smith, Made it in the Timber: A History Overview of the Fort Leonard Wood Region, 1800-1940, (Normal, Illinois: Midwestern Archaeological Research Center, Illinois State University, 1993), p. 78.

${ }^{84}$ Harold R. Klobe, "Fort Leonard Wood, Missouri: Construction and Impact on the Civilian Community 1940-41" 17, November 1993, History 601 research paper, location unknown (Fort Leonard Wood, Missouri: on file, History Office, U.S. Army Engineer Center). 


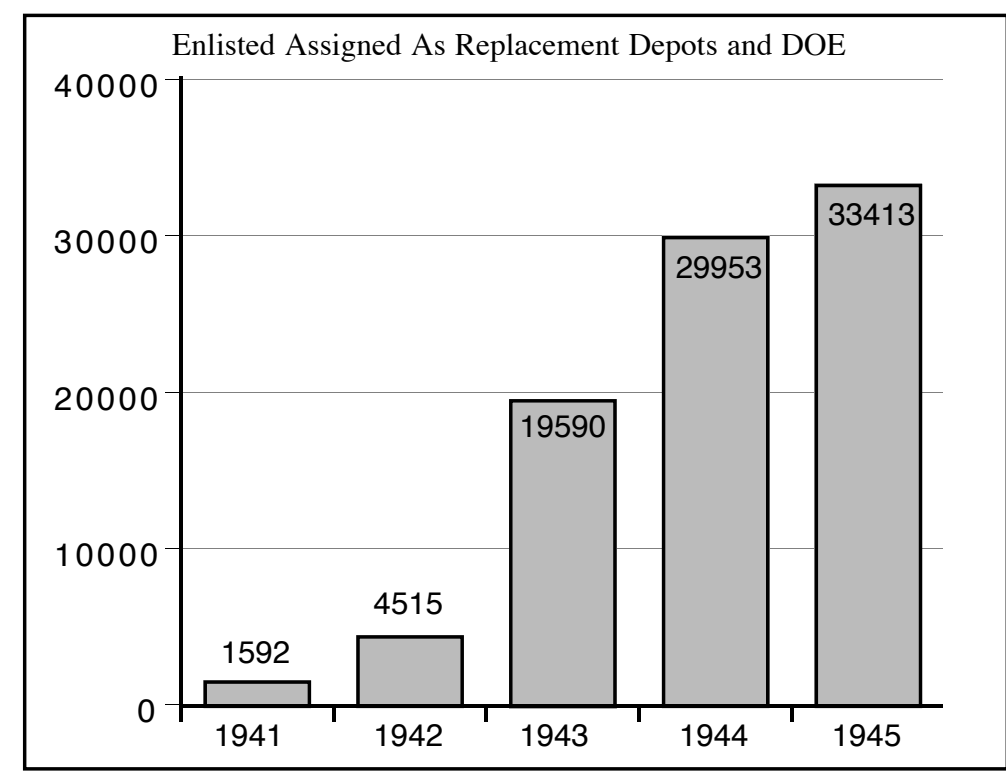

Figure 2.12 Enlisted Assigned as Replacements (From Training of Replacements, Fillers).
As far as outspoken antipathy toward blacks by the local population, there are hints that the general was speaking from first hand knowledge. A novel, clearly based on real experiences, provides some hint as to at least some of the local attitudes towards blacks. The novel is about a teacher who comes to the region during the Depression. During the course of the school year the teacher lends a book to the child of the only black family in the school district. Shortly thereafter, a grass fire is started near his house, which was a traditional method of expressing angst among Ozark people. At the end of the term, the teacher decides to leave. This story is admittedly only circumstantial evidence of local feelings, but there are other indications of antipathy. ${ }^{85}$

In February 1942, for instance, a soldier complained to the NAACP that he and a companion had been asked to move to the rear seats of a bus traveling from Fort Leonard Wood to Kansas City. ${ }^{86}$ Sometime in November 1942, there was an incident in the county jail involving two black soldiers. Why the two soldiers were there or what happened is not known, but the Executive Officer of the black 35th Training Battalion was ordered to investigate. The post Provost Marshall testified that he knew of no adverse feeling on the part of Waynesville residents (the nearby local village and county seat). Waynesville citizens were reported to have stated that feelings did run high after the incident but had cooled since and nothing more was heard about the incident or the presence of blacks in the village. They admitted that Waynesville merchants did not desire black business, but handled "what colored business they have." It was their general opinion that blacks had always "kept their place" and conducted themselves properly. This statement and another, that few blacks were actually seen in Waynesville except at the bus stations, would indicate that blacks stationed at the fort recognized that they were only reluctantly welcome in Waynesville and thus they tended to avoid the town. In fact, keeping the black soldiers away from local residents in order to squash potential racial incidents was an intentional strategy on the part of the military. In response to a November 1941, Army-wide survey ordered by General George Marshall regarding the stationing of black troops, General Grant responded that:

${ }_{85}$ Joseph Nelson, Backwoods Teacher (Philadelphia: J.B. Lippincott Company, 1949).

${ }^{86}$ Letter, Thomas W. Mckay to Mr. Walter White, Secretary, NAACP, 3 February 1942, "Discrimination In The U.S. Armed Forces, 1918-1950," Papers of the NAACP, Part 9, Series B, Soldier Complaints, Reel 15, 0510 (University of South Carolina, Columbia: microfilm, Thomas Cooper Library). 
So far there has been no friction between colored soldiers of the ERTC and white civilians, but this has been brought about mainly by constant study of the situation and continuous effort to keep the colored soldiers busy both at work and at recreation. Sustained efforts by this Headquarters, the Post Commander and the local USO officials, together with the good behavior of the men themselves, have largely done away with the hostility towards them originally felt by the local population. ${ }^{87}$

Eventually, black soldiers and white civilians met, and, as seen above, the friction seems to have begun in 1942. Since feelings had cooled after the incident in the county jail, the 7th Group's off-limits restriction for Waynesville was lifted. ${ }^{88}$ However, other restrictions occurred that indicate racial unease between the surrounding community and troops stationed at Fort Leonard Wood. A Daily Information Bulletin issued in January 1943, placed black establishments within 50 miles of Fort Leonard Wood off-limits to white military personnel at all times and to all military personnel after 2400 on week nights and 0130 on Sunday morning. ${ }^{89}$ What triggered this order is not known. While there is certainly nothing unusual about placing certain areas off-limits to troops on leave, the fact that white soldiers were ordered away from black establishments indicates a concern on the part of the ERTC command. This may have been a preventative measure or the result of a particular incident. There must have been very few of these black owned businesses in the region, most likely located beyond Pulaski County--probably in Rolla and Lebanon, Missouri.

Importantly for full

understanding of this problem, the attitudes described above were not unique to Waynesville, nor do they point to any unusual angst on the part of Waynesville residents. Rather these feelings were, unfortunately, quite common in the rural South at this time. They were an established part of a Jim Crow society, a culture in which blacks and whites lived close together but apart in a tightly segregated world. A tense peace was kept as long as blacks were subservient and did not challenge

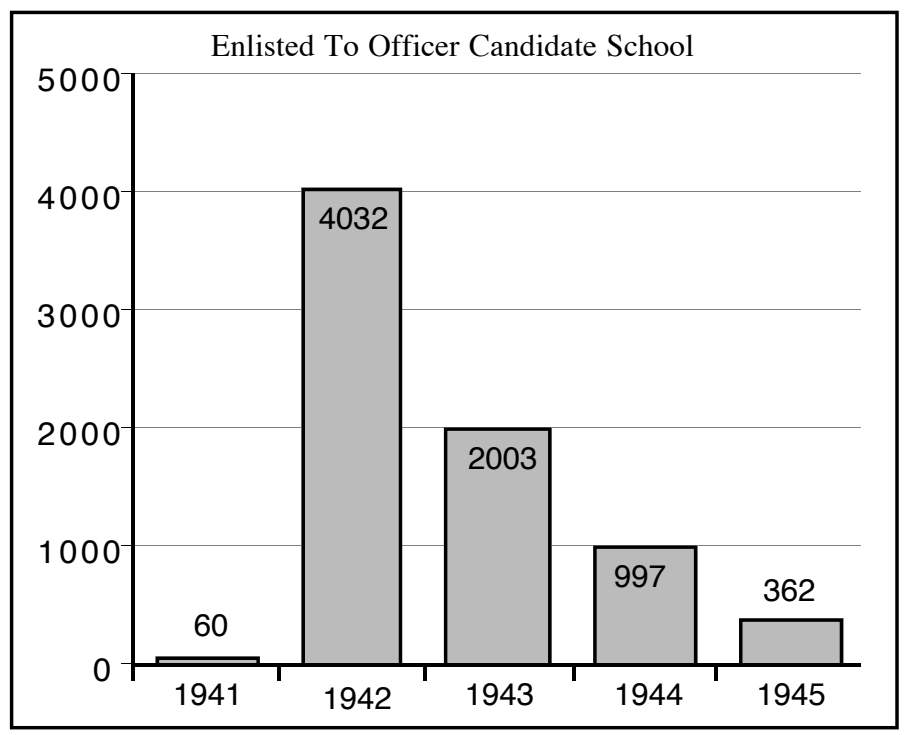

Figure 2.13 Enlisted To OCS (From Training of Replacements, Fillers).

$\overline{87}$ Memorandum, Commanding Officer, ERTC to Commanding Officer Fort Leonard Wood, Missouri, 19 December, 1941 (Fort Leonard Wood, Missouri: on file, History Office, U.S. Army Engineer Center).

${ }_{88}$ Major Edmund L. Gaumer, "Memorandum, Investigation, Waynesville, Missouri," 25 November 1942, (Fort Leonard Wood, Missouri: on file, History Office, U.S. Army Engineer Center).

${ }^{89}$ Daily Information Bulletin, Fort Leonard Wood, 9 January 1943, Record Group 107, Records of the Office of the Secretary of War, Judge Hastie Files, Entry 91, Box 268, file entitled "Fort Leonard Wood" (College Park, Maryland: National Archives II). 
the status quo. It seems very possible that both the black military community at Fort Leonard Wood and the white civilian community attempted to avoid each other. The result was that there were few clashes between black soldiers and Pulaski County residents, or at least few reported in the local and national newspapers. Again, the one reason for this may well have been that Fort Leonard Wood did not have large numbers of northern blacks. Racial tensions were heated to a flash point by the influx of northern blacks into southern installations during WWII. Northern black men and women often had no previous experience with Jim Crow's institutional racism, or with the subculture that developed among southern blacks in surviving this institution. A clear example of this was seen near Gurdon, Arkansas, where northern black troops clashed with white natives and police in August of 1941. White officers in charge of these troops were also attacked when they attempted to defend the black soldiers. Fearing for their lives, some northern black soldiers went AWOL in an attempt to get back north where they felt safe. A Chicago Defender newspaper article describing the events mentioned that "At the same time there are other colored soldiers from Fort Leonard Wood, Missouri .... These soldiers come mainly from the South. Thus far there has been no friction between them and the white natives. ${ }^{190}$ Southern blacks knew the survival skills for living in Jim Crow South.

Racial tension in the Fort Leonard Wood ERTC also was evident, and as usual, was displayed in highly complex situations. Black soldiers at the installation met with the entire range of human experience regarding race relations. At the war's beginning, at least, black soldiers at the fort, like those across the nation, hoped that the war would bring new opportunities for solving race problems. One black man at Fort Leonard Wood wrote to a black newspaper on August 2, 1941, that he and other soldiers "would like to put in a good word for this camp." Apparently, the black press had been reporting race-related controversies at the installation, and he and other men were writing in hopes that the "Negro press is presenting pure facts and not accepting the words of some disgruntled soldier or reporter's statement who can see no good in anything where two races are concerned." The letter concluded that "We are Americans and want to do our part in any crisis. We who are training at Fort Leonard Wood feel that we are getting the proper type of training, regardless of race, creed or color, which will enable us to do our part efficiently and willingly when and if the time comes." ${ }^{191}$ This letter was later forwarded to Miss Emily Dembitz of Louisville, Kentucky, who had written to the President of the United States complaining that black soldiers worked 16 hours a day while white soldiers only worked eight. ${ }^{92}$

The ERTC not only took vigorous steps to avoid racial conflict on post, but being a training command it had some advantages, especially at the beginning. The men were sent in as civilians,

$\overline{{ }^{90}}$ Buchanan, Black Americans, p. 80; "Soldiers Beg Ammunition to Fight Mobs," Chicago Defender 23 August 1941.

${ }^{91}$ Letter, Wilbur W. Sewell, 2 August 1941 (Fort Leonard Wood, Missouri: on file, History Office, U.S. Army Engineer Center).

${ }^{92}$ Letter, Captain C.E. Campbell to Miss Emily Dembitz, 21 November 1942 (Fort Leonard Wood, Missouri: on file, History Office, U.S. Army Engineer Center). 
were pushed through an intensive basic program and quickly sent on their way, while new draftees just as quickly filled their bunks. There was little time for anything but training. Mr. Perry Cox, a white veteran of the ERTC who was among the first arrivals in May 1941, told the author that he had no contact whatsoever with the black troops. He knew where they were on post and assumed that they had their own post exchange and recreational facilities because he never saw any where he was. ${ }^{93}$ As the initial mobilization frenzy passed and unit training began, the danger of racial problems increased.

As the war progressed, it is clear that racial issues and incidents would not avoid Fort Leonard Wood and they first appeared in 1942. In April of that year a letter signed "Men of Fort Leonard Wood" was addressed to Judge William H. Hastie, who had been appointed Civilian Aide on Negro Affairs in the Office of the Secretary of War. It was a plea "in behalf of we 'Negro Slaves' of Fort Leonard Wood." The letter was written to advise Hastie of the "...Cheap morale breaking technique used by Commanding Officers of this camp to keep the Negro youth of Fort Leonard Wood in a servile and very much subordinate position." The complaint was that blacks were not being promoted any higher than corporal in the ERTC. When blacks applied themselves to the task and were eligible for promotion it seemed to these soldiers that they were transferred to another camp or some other tactic was used to deny them the opportunity for advancement. In the black 7th Group there were no black non-commissioned officers. They also reported that it was "general knowledge" that a special order had been issued stating that blacks would not be made Master, Technical or Staff Sergeant. ${ }^{94}$ No record of this policy has been found, but clearly blacks felt they were being overlooked for promotion at the ERTC. It is not known what the ERTC's position was on this matter, but it is to be remembered that the command had requested black clerks and cadre from the Seventh Army Corps even before the center opened.

That fall, in September 1942, a memorandum was issued that smacked of Jim Crow policies at the post hospital. In the memorandum black patients were told they could not go to the mess hall until authorized by a nurse or wardmaster who had to call ahead. The reason given was that authorities were attempting to control crowding in the mess hall and corridors. It makes sense that the staff would not want hospital corridors crowded full of waiting soldiers, but apparently white soldiers had more freedom to come and go as they desired. ${ }^{95}$ It is also possible that hospital authorities were attempting to keep black and white soldiers from waiting in mess lines together or eating together, where incidents might occur. Certainly black patients felt they were being discriminated against and further evidence indicates that this perception, and probably this

${ }_{93}$ Mr. Perry Cox, Brownwood, Texas, telephone interview with author, 15 June 1942.

${ }^{94}$ Letter, Men of Fort Leonard Wood to Judge Hastie, 30 April 1942, in Phillip McGuire, Taps for a Jim Crow Army, Letters from Black Soldiers in World War II, (Santa Barbara, California: ABC-Clio, Inc., 1983), pp. 106108.

${ }^{95}$ Memorandum, 22 September 1942. Record Group 107, Records of the Office of the Secretary of War, Judge Hastie Files, Entry 91, Box 268, file entitled "Fort Leonard Wood" (College Park, Maryland: National Archives II). 
discrimination, continued. On May 5, 1944, Private DeLeon Wood wrote from the Fort Leonard Wood hospital that he felt like a prisoner in the hospital as it had bars on the windows, he had to get a pass from an officer to go anywhere, and "it seem to be a great job for me to get one."196

Sometime in late 1944 or early 1945 there was an alleged beating incident in the post guard house involving black soldiers. Private Raleigh Simmons had been arrested and taken to the guard house for protesting when he was put on a work detail which entailed lifting 175 pound artillery shells. Simmons complained of a back ailment and was unable to lift the shells. While in the guard house, Simmons complained he was beaten on more than one occasion by the M.P.s. ${ }^{97}$ Its possible he was not the only prisoner beaten. A letter signed "American Negroes" and sent to the Amsterdam News was written at about the same time to "let you know of the condition of this camp and what most colored soldiers have to go through. We are treated worse than dogs here in the guard house." The Army took action this time. In January 1945, an investigation of these beatings was ordered. A memorandum recommended punitive action against the guards and the captain in charge, and courts martial were ordered. ${ }^{98}$ The Army took "corrective action" although it is not known what it was. Clearly, though, the guard house was not the place to be for black soldiers. In a separate case, another black private went AWOL when he was refused leave to visit his sick mother in Florida. While there he was arrested by the local police and was beaten. He was then taken to Camp Blanding and left for a month before being sent back to Fort Leonard Wood's guard house where he was when he finally wrote the NAACP in protest. The private had been refused medical treatment for his beating both at Camp Blanding and Fort Leonard Wood. ${ }^{99}$

Beginning in mid-1945 leadership challenges at Fort Leonard Wood and the ERTC took on a different character and the command once again prepared for potential racial problems. Soldiers from overseas were being stationed at Fort Leonard Wood for reassignment or demobilization. These soldiers had a different attitude than the men of 1942. Lacking the patriotic fever seen at the war's beginning, the soldiers of 1945 returned to the states having experienced both the terror of combat and the behind-the-frontlines boredom. They were decidedly tired of military life. Many black overseas veterans also were jaded by their wartime treatment, including their assignment primarily to service units. They had, in fact, been treated much as black soldiers had been treated in previous wars. Although an Activities Report dated March 18, 1945, noted that "Thus far, there

${ }^{96}$ Letter, Private Deleon J. Wood to Mr. Truman K. Gibson, 5 May 1944, in Phillip McGuire, Taps, p. 223.

${ }_{97}$ Washington Bureau, NAACP, Press Release, 23 April 1945 Press Release, April 23, 1945, NAACP, Washington D.C., Papers of the NAACP, Part 9, Series B, "Discrimination In The U.S. Armed Forces, 19181950," Soldier Complaints, Reel 13, 0556 (Microfilm, Thomas Cooper Library, University of South Carolina, Columbia.

${ }^{98}$ Letter and Memorandum, 12 January 1945. Record Group 107, Records of the Office of the Secretary of War, Judge Hastie Files, Entry 91, Box 268, file entitled "Fort Leonard Wood" (College Park, Maryland: National Archives II).

${ }^{99}$ Letter of Private Charles Green to the NAACP, no date. Papers of the NAACP, Part 9, Series B, "Discrimination In The U.S. Armed Forces, 1918-1950," Soldier Complaints, Reel 12, 0166 (University of South Carolina, Columbia, microfilm, Thomas Cooper Library). 
have been no indications of racial tension on the post, or in nearby communities," the post prepared for an expected influx of blacks resulting from the order that all black engineer soldiers would be trained at Fort Leonard Wood, and the imminent arrival of overseas veterans including 11 Dump Truck Companies. ${ }^{100}$ Preparations included a recommendation that a Negro Military Police Detachment be formed. Black military police, according to the recommendation, had been assigned previously and "had been of great value in administering Negro troops." "Experience indicates that the returned overseas Negro veteran presents a far more serious disciplinary problem than the new inductee," the recommendation stated, and that with the increased military population expected, disciplinary problems also could be expected to increase. "It is inevitable that some of the incidents will partake of a racial aspect."101 The black M.P.s were formed and worked closely with the white M.P.s during subsequent peak troop off-duty hours like Saturdays and Sundays.

The examples above point clearly to racial tensions at Fort Leonard Wood, although the installation avoided serious conflicts. There was one other known racial incident at Fort Leonard Wood. This one involved officers on post and will be discussed in the next chapter.

\section{Black Units In the Army Ground Forces at Fort Leonard Wood}

Besides the ERTC 7th Training Group, there were other black units on post at Fort Leonard Wood. Most of these were with the Army Ground Forces (AGF). But when the ASFTC was ordered to provide unit training, black service units increased. ERTC graduates were often assigned to these units upon graduation or to the Army Ground Forces units. Mr. Perry Cox remarked to the author that he felt very sorry for the black troops at Fort Leonard Wood because they remained on post after their basic was completed while he was immediately shipped-off to a unit. Whether this remained the pattern throughout the war it is not known, but as has been seen, black troops, once trained, could only fill segregated black engineer units. So the difficulty in filling quotas and meeting schedules probably did delay the flow of black trainees in and out of the ERTC/ASFTC throughout the war.

It was impossible to discover all of the black units on post during the rapidly changing war, but the following are known. Prior to its opening, there were plans for the 6th Signal Company (Construction), the 29th Quartermaster Regiment (Truck), the 228th Quartermaster Company, the 576th Engineer Company (Dump truck), the 92nd Engineer Battalion, and the Colored Component of the CASC, to be stationed at the installation. ${ }^{102}$ A construction landscape report confirms that

${ }_{100}$ Memorandum, Major Charles H. Flourney to the Chief of Engineers, Washington D.C., 18 March 1945 (Fort Leonard Wood, Missouri: on file, History Office, U.S. Army Engineer Center).

${ }_{101}$ Memorandum, Commanding Officer, Fort Leonard Wood to Commanding Officer, 7th Service Center, ASF, Omaha, Nebraska, 22 June 1945 (Fort Leonard Wood, Missouri: on file, History Office, U.S. Army Engineer Center).

${ }^{102}$ Letter, Strong to the Adjutant General, February 1941 (Fort Leonard Wood, Missouri: on file, History Office, U.S. Army Engineer Center). Exactly what "CASC" means is unknown to the author, but it is believed to be a service or administrative unit. 
these units were still planned and facilities were being constructed for them in April 1941. ${ }^{103}$ After the ERTC opened, some of the first training center graduates were to be organized into the following units at Fort Leonard Wood: 45th Engineer Regiment (General Service), the 576th and 585th Engineer Companies (Dump Truck), the 98th Engineer Battalion (Sep). ${ }^{104}$ Also, General Davis's Special Inspection report of June 22, 1942, lists besides the ERTC, the 716th Medical Sanitary Company, consisting of two officers and 125 enlisted men, and a Quartermaster Corps, probably one of those listed above, consisting of one officer and 141 men and "Detached Enlisted Men's List" consisting of one officer and 76 enlisted men. ${ }^{105}$ Exactly how long these units were at Fort Leonard Wood is not known.

There were surely many other Army Ground Force black units at Fort Leonard Wood between its opening and its closing in March 1946. It is known that in late 1945 just before the closing of Fort Leonard Wood there were 12 black Truck Companies. ${ }^{106}$ Except for the 646th Quartermaster Truck Company and the 3401st QM Truck Company, their unit designations are unknown. ${ }^{107}$ Most likely this list is very abbreviated and black services units were flowing in and out of the post throughout the war period.

\section{Summary}

The African American soldier entered WWII under the stigma of a WWI record that was perceived to have been not up to the usual Army standard. Elements affecting this record, such as inadequate educational and leadership opportunities in the civilian world, poor training, poor equipment, and inadequate preparation, were overshadowed by the harsh testimony of white commanders who were highly sensitive of their own poor record. Through the 1920s prejudice worked to almost totally strip the black man from ranks of the post-war army. Still, Army policymakers recognized their duty to the Constitution and planned for the future black mobilization according to their representation in the general population, albeit in segregated units. Within the U.S. Army Engineers, there was a reluctance to include the black draftee in their mobilization plans because of a belief that the engineers required men with advanced technical skills not found in the general African American population.

\footnotetext{
${ }_{103}$ Francis A. Robinson, "Fort Leonard Wood, Landscape Development Report," (Fort Leonard Wood, Missouri: Alvord, Burdick, Robinson \& Parnham, on file, History Office, U.S. Army Engineer Center 1941), p. 3.

104 "Corps of Engineers," Army Navy Journal, 31 May 1941.

${ }^{105}$ General Benjamin Davis to The Inspector General, 22 June 1942 (Fort Leonard Wood, Missouri: on file, History Office, U.S. Army Engineer Center).

${ }^{106}$ Colonel H.W. Schull, Jr. to Commanding General, Army Service Forces, "Inspection of the ASFTC, Fort Leonard Wood, Missouri," 8 October 1945 (Fort Leonard Wood, Missouri: on file, History Office, U.S. Army Engineer Center).

107 Memorandum, Brigadier General Henry C. Wolf, ASF, to Deputy Chief of Staff, ASF, 3 January 1946, RG 160 Army Service Forces (College Park, Maryland, National Archives II).
} 
Once mobilization for WWII began, thousands of black men were soon on their way to new installations across the nation, but most of these installations were in the South. Among those new installations was Fort Leonard Wood, Missouri, where black and white citizens were to be turned into basic engineer soldiers. There, the new soldier found himself amidst a helter-skelter pace of tenuously organized activity. He was quickly thrown into this furious activity to learn the skills of a soldier. In almost no time, as few as eight to 12 weeks, he was turned from a civilian into an engineer soldier and shipped to an engineer unit. If he was white he went to a combat unit, if black he much more often went to a service or labor unit. Training was difficult and dangerous, and there was little time for much else. It was no wonder that there were few racial incidents on or off post. General Grant and his successors kept their promise to keep the men busy. Racial tensions of a more serious nature flared toward the end of the war. As the war wound down the men had more time on their hands, and most were ready to return to the civilian world. The most serious incident was the beating in the 7th Group's Guard House and Fort Leonard Wood responded with justice. Overall, Fort Leonard Wood met the challenges imposed by an Army-wide policy of segregation and no large scale racial incidents occurred.

In looking at the mission, the lack of training aids, the pace of war change, and the course challenges, Fort Leonard Wood's ERTC/ ASFTC did an astounding job in turning thousands of men into engineer soldiers--at least as measured against the success of their graduates on battlefields across Europe and the Pacific Islands. Combat units usually have unit histories written about their successes and failures, and until the 1960s many had great traditions extending back into the country's beginnings. Training units, on the other hand, usually have no histories. This brief overview though, indicates that training during WWII was a tremendous challenge and at Fort Leonard Wood, the Army Engineers met that challenge. Among those successfully trained at Fort Leonard Wood were thousands of black soldiers, who more often than not ended up in service units-units and men necessary to win wars, but not often seen in the front lines when the unit citations and medals are handed out. Without them, and without such training centers, the front lines would not have held or advanced. 


\section{CHAPTER III: BLACK OFFICERS AT FORT LEONARD WOOD}

\section{Introduction}

Among the thousands of black personnel at Fort Leonard Wood during WWII were an unknown but small number of black officers. If it was possible to add to the stress of the rapidly changing wartime environment, the life transformation from civilian to military culture, and Jim Crow civilian and military policies, then the additional pressure of being a black junior officer must have created one of the most stress-filled wartime experiences imaginable, excluding combat. Phillip McGuire, in his book Taps for a Jim Crow Army, includes a chapter on the challenges and opposition black officers faced at installations across the nation appropriately entitled "The Dilemma of the Black Officer." 'What to do with the black officer?' was one of the continuing issues facing Army policy makers and installation commanders, and only post-war integration even remotely began to solve this issue. Given the circumstances, it was unsolvable in the first half of the 1940s and the results were predictable. There is very little specific documentary reference to the conditions and experiences of Fort Leonard Wood's black officer corps, but what is available points to the fact that black officers there faced the same challenges as black officers throughout the military. Thus, this section discusses black officers' experiences, lives and fortunes across the nation with reference, where possible, to the black officers at Fort Leonard Wood.

\section{Black Officers In World War II}

The prewar and initial Army policies regarding black officer utilization were detailed in Chapter II. Army policy may be summarized as follows: 1) black officer candidates would be held to the same standard as whites; 2) as commissioned officers they could command black troops, but not white; 3) black officers would be confined to Reserve, National Guard and service units. ${ }^{1}$ Little changed about this policy during the war, although in April 1942, the War Department did decide that black officers could, under limited conditions, command white enlisted, but would be prohibited from commanding white officers. Even in the few instances where black officers were senior to whites in the same unit, it was made perfectly clear in practice that no black officer, regardless of grade, would be superior to the most junior white officer. Throughout the war, barriers were thrown-up to block the unrestricted use of black officers, often aided by Army policy. Lack of previous educational experience, for example, meant that few black draftees could meet the same standards required of white candidates, like a minimum score of 110 on the Army General Classification Tests. ${ }^{2}$ Therefore many blacks failed to even be considered for Officer Candidate School. Finding qualified black candidates was truly difficult, made even more difficult by the

Lee, Employment, p. 50 .

2 McGuire, Taps, pp. 31-35; Lee Employment, pp. 205-238. 
fact that many experienced black non-commissioned officers with proven leadership skills had no desire to face the challenges of being a junior officer--they knew the black officer received no respect as persons or as officers and would be given few challenging assignments. Thus, those blacks who passed the exam and graduated from Officer Candidate School were usually college educated northern blacks with no previous military experience or experience with the Jim Crow south where many of the new installations were built. This combination would add to the tension of being a black officer. Still, those that passed the qualifications exams entered what was one of the Army's first formal experiments with integration. Officer Candidate Schools were integrated on the basis that all officers would be treated the same. White and black officers trained together in integrated classes, although housing, messing, and recreational facilities were subject to local installation control, and at posts with large numbers of black officers, they tended to have segregated housing and mess facilities. ${ }^{3}$

Those who graduated from Officer Candidate School faced the difficult problem of assignment. The first hurdle was finding a slot among the restricted number of black units being established. To avoid the problem of a black officer potentially being in command of white officers, black officers were going to have to be promoted in blocks as needed (and based on other policy restrictions), and then assigned to black units. This made rewarding competent individual black leadership very difficult as the war progressed. But that was only one challenge. Commanders also had to find posts and units where black officers could function, given the Army's restrictions and the reactions of both military personnel and civilians. Many white officers, for instance, resented black officers and would not serve with, recognize, or assist black officers. When mixed black and white officer staffs did occur, leadership problems appeared even when cooperation existed. For instance, separate but equal policies often meant different housing and facilities, thwarting the possibility of forging a unified command (the problem of facilities will be discussed in Chapter III). Further, because there were so few black officers during the period between the wars, experienced white officers usually had had no experience working with black officers, a problem also seen among new white officers who had not worked with blacks in the civilian world. Off-post, many white civilians would tolerate black enlisted men, but were outwardly resentful of black officers (i.e., blacks in authority), and such attitudes were not confined to the southern installations. If the local attitudes of the surrounding communities were decidedly anti-black, then this further restricted the kinds of duties that black officers could be assigned. It would do little good to have black officers on guard duty or assign them to assist in control of black soldiers off-post on Saturday nights. White officers had to take up the slack, which did no good toward building the relationship between white and black officers.

The Army's policy restrictions on where a black officer could be assigned and prejudices working against them, often left them in limbo while commanders found suitable assignments. No one seemed to know what to do with the black officer and sometimes the answer was to ship them

${ }^{3}$ MacGregor, Integration, p. 51. 
somewhere else. Lieutenant Colonel Jessie J. Johnson, who was a young black Second Lieutenant during WWII found himself on the move constantly:

It was a repetition of this procedure at every camp or post during World War II. In every war the Negro officer has found himself without duty assignments. He has been excess, while all around him there was so much to be done. He has had to learn to fill this void, this vacuum into which he was forced; he has had to find something constructive to do and still remain on post, available on call. ${ }^{4}$

Black officers, who were transferred from post to post, began to call themselves "traveling second lieutenants," as upwards of 20 to 30 of them would meet in pools waiting for assignment.

Even among their own race, maintaining proper military order was difficult for black officers. Black enlisted and non-commissioned men saw that black officers were not treated equally by white officers and though resenting the distinction, were conflicted in following a black officers' orders. This obviously did nothing to help the fortunes of black officers and only confirmed in the minds of Army policy makers that blacks could not lead. Again, Johnson's words summarized this problem in a personal way: "Negro enlisted men wondered what was happening. Some of them scorned our apparent laziness; others complained about our second-class assignments. Were we officers or weren't we? None of us could tell them, because we didn't know either." ${ }^{5}$

White officers in WWII made the same complaints against black officers heard during WWI. These included charges that black officers worked by the clock instead of getting the job done no matter how long it took, that they disappeared in times of crisis, and that they lacked initiative and aggressiveness in combat. Further, black officers sided with black enlisted men in disciplinary situations (and in this same light, they failed to maintain a proper distance from black enlisted or observe the time honored officer code of conduct), and they carried a 'chip-on-theshoulder' attitude and sensitivity in perceived slights. ${ }^{6}$ This latter complaint was the outward manifestation of the tangled environment in which black officers found themselves. Prejudices and Jim Crow were a reality, and thus, in every interaction with a white officer colleague or superior there was the possibility for misunderstanding. How should a black officer interpret and react toward a comment, a glance, a seeming or real injustice? Again, part of this attitude stemmed directly from the fact that black officers, most well-educated college men and women from the North, were experiencing for the first time life in the Jim Crow South. Fearing discrimination, and being subjected to very real incidents of discrimination, many black officers became suspicious of any attempts at camaraderie by white officers. Many black officers developed a defensive attitude to

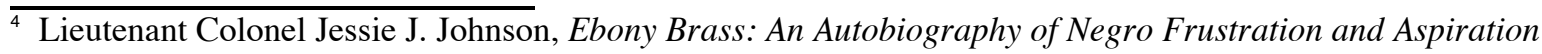
(New York: The William-Frederick Press, 1967), p. 45.

${ }^{5}$ Ibid., p. 57.

6 Major Bell I. Wiley, The Training of Negro Troops, Study No. 36, Historical Section, Army Ground Forces (Washington D.C.: Headquarters Army Ground Forces, 1946), p. 28-29. 
such an extreme that white officers, previously supportive of black officers, became disillusioned and exasperated by black officer attitudes. As Lt. Colonel Johnson saw it, the result was that black officers in World War II fell into various categories. Colonel Johnson's observations were that some black officers: 1) varied in their ability to forget the racial barriers of their former civilian lives which caused strained relationships with white officers; 2) succumbed to the discrimination and neglected their duties through resignation to the situation or belligerency; 3) carried a chip-ontheir-shoulder (see above), looking for trouble; 4) fell to extreme discipline of subordinates; 5) were over conscious of rank, even among themselves; and 6) like all humans, some were careless and inefficient while others were ambitious and industrious. ${ }^{7}$ In other words, they reacted as all people would to the enraging situation where they held the rank and responsibility of professional military officers, but in practice could command none of the support or respect needed to efficiently carry out their duties. Interestingly though, the categories described by Colonel Johnson are hauntingly similar to the conclusions reached by Army historians immediately following the war. Thus it seems clear that at least one black officer and most likely others, recognized the problem, but they were in most cases so much caught up in the issue's complexity that they could do little to solve it themselves. Further as most were junior officers, they had little authority to enact any solutions. There is little wonder that some resigned themselves to inaction and were perceived as inefficient or lazy--what was the use?

Not surprisingly, the conclusions drawn as a result of the WWII experience echoed those of WWI. While not coming right out and calling them a failure, Major Bell I. Wiley's conclusion in The Training of Negro Troops that "With the exception of a small minority they were lacking in initiative, self-confidence, aggressiveness, and a strong sense of responsibility," comes as about as close as one can. ${ }^{8}$ Other conclusions drawn include the complaint that "There was not enough colored leadership material . . .to fill noncommissioned officer positions, let alone provide capable platoon and company commanders." Also,

Assignment of white and colored officers to the same units proved undesirable. Regardless of pressure from above, white officers as a rule avoided intimate association with colored officers, and this fact was resented by Negros. Moreover, the better background of white officers resulted in their being promoted more rapidly than their colored associates, and this led to ill-feelings and charges of discrimination on the part of the latter.

Colored infantry units having Negro officers were greatly inferior both in training and in combat to those having white officers. The disparity was not so great in other kinds of unit. In some instances, colored artillery, engineer, and service units officered by Negros performed acceptably in theaters of operations. ${ }^{9}$

\footnotetext{
7 Johnson, Ebony Brass, p. 58.

8 Wiley, The Training of Negro Troops, p. iii.

9 Ibid., pp. 56-57.
} 
By the end of WWII, many black officers were as disillusioned with the Army as the enlisted men. As one black officer exclaimed when asked if he was going to stay in, "Are you kidding? At least in civilian life the discrimination is not organized." ${ }^{10}$

\section{Black Engineer Officers At Fort Leonard Wood}

It is impossible to get a firm figure on the number of black officer engineers at Fort Leonard Wood during WWII but there were not that many. An estimate of between 300 and 500 over the course of the entire war is offered, based on the following information. In 1942 there were only 534 black officers in the entire armed forces. By 1943 this had changed dramatically. Army units alone that year included 3,638 black officers; broken down as follows: 3,367 male officers and 105 female officers, plus 166 warrant officers. Throughout 1944, the number of black Army officers, male and female, hovered in the high 4,000s and in 1945, the mid-5,000s. ${ }^{11}$ The highest number of black officers in the Army in any one month of the war was 6,727 (6,030 male officers, 105 female officers, plus 592 warrant officers) in September 1945. Still, during that September, when the number of black officers in the Army was at its highest level, these officers represented only one percent of the 653,563 blacks in the Army, which in turn represented only $9.68 \%$ of the total American manpower.

But these numbers begin to shrink when breaking them down by type of service and Army branch. For instance, in June 1944 there were only 1,221 black officers in the Army Ground Forces, and this drops dramatically to only 471 in December of 1944, and 164 by June 1945. ${ }^{12}$ Of those, only 177 were with the engineers; broken down as one Lieutenant Colonel, three Majors, six Captains, 34 First Lieutenants, and 133 Second Lieutenants. ${ }^{13}$ The number of black engineer officers in the Army Ground Forces dropped dramatically after mid 1943. At the end of 1943, there were only 39 black engineer officers, 12 First Lieutenants and 27 Second Lieutenants. The figures for 1944 and 1945 are even more dramatic, only 16 black engineer officers in June 1944, and one at the end of 1944; there were only two in mid-1945. ${ }^{14}$ By June 1945, there were only 164 black officers in the Army Ground Forces, and only two of those were in the combat engineers. How many of these trained at Fort Leonard Wood is unknown. However, if they went to a combat unit directly out of OCS, they most likely would not have gone to Fort Leonard Wood.

Obviously the vast majority of black officers were with the Army Service Forces. Unfortunately, historical sources on the ASF do not indicate the number of black officers under its control or even the number of personnel in the ASF. So, from these number we must go to the fragmentary incidental records at Fort Leonard Wood to get an estimate of the number of black

\footnotetext{
$\overline{{ }^{10} \text { Johnson, Ebony Brass, pp. 58, } 65 .}$

11 Lee Employment, pp. 416-417.

${ }^{12}$ Wiley, The Training of Negro Troops, pp. 22-24

${ }_{13}$ Ibid., pp. 22-24.

${ }^{14}$ Ibid., pp. 22-24.
} 
officers on post. At its peak population, there were possibly as many as 50 to 100 black engineer officers at one time on post. This estimate is based on a variety of incidental evidence in existing records. A letter, further discussed below, asserts that there were 40 black engineer officers in the Army around November 1942. A memo dated December 28, 1942, stated that "It is to be noted that in the 34th Battalion, there are 35 Negro officers of company grade, only the company commanders and three of the administrative officers being white." ${ }^{15}$ Fort Leonard Wood then was host to the majority of black engineer officers in 1942. After August 1943, all black enlisted in the ERTC were trained at Fort Leonard Wood and this likely increased the number of black engineer officers on post. On August 15, 1943, just when the policy regarding the training of blacks soldiers was being formulated, a memo was sent from Fort Leonard Wood to higher headquarters requesting that 84 black officers be reassigned as there were too many "Negro officers" on post. ${ }^{16}$ This number, from all other accounts seems high and very well may be a typographical error. Regardless, Fort Leonard Wood may have had as many as 100 black officers on post at that time. With 35 in December 1942, and perhaps as many as 100 in the fall of 1943, 200 black officers by 1944 would seem reasonable. At that point it would seem that black officers increased in the Army across the board so that another 100 is possible by the fall of 1945 , which provides a high estimate of as may as 300 individual black officers passing through the gates of Fort Leonard Wood during the war. This is highly speculative, but as the records are extremely poor, is the best that can be done.

For the comparatively large numbers of black engineer officers that were there, the documentary evidence available about their lives at Fort Leonard Wood is, as stated, spotty. It is known that all black officers were assigned to the ERTC's 7th Group regardless of whether they were on staff with the 7th, assigned to black service units, or part of the engineer officer pool waiting reassignment. Officer candidates also trained in integrated units but were assigned to the 7th for administrative purposes. Almost nothing is known about their performance. In November 1944, an inspection report mentions that "several" black officers from the "pool" on post had been placed as platoon leaders and "show[ed] satisfactory promise and the moral effect has been very good. [Further], A rather unsatisfactory colored chaplain has also been relieved and replaced by a colored chaplain with overseas service and who seems to possess the right qualities of leadership." ${ }^{17}$

It is possible that during early part of the war, that is the time in which General Grant and Colonel Besson were in command, the black officers were kept apart from the white officers. For Instance, Mr Edward Reep was a 2nd Lieutenant during the war and was stationed at Fort Leonard Wood from December 1942 until February 1943. During that brief period in which he commanded a

\footnotetext{
${ }_{15}$ Colonel Frank S. Besson, Memo attached to Memorandum To Colonel E. H. Coe, 29 December 1942 (Fort Leonard Wood, Missouri: on file, History Office, U.S. Army Engineer Center).

${ }^{16}$ Anon., "Cards."

17 E.G. Paules, Colonel Corps of Engineers, "Inspection of Army Service Forces Training Center, Fort Leonard Wood, Missouri," 14 November 1944 (Fort Leonard Wood, Missouri: on file, History Office, U.S. Army Engineer Center).
} 
platoon in the black 7th Group, Reep never saw one black officer and was not even aware of their presence on post. This could be an indication that black and white officers were kept quite separate, or an example of how busy Grant was keeping the troops. After all, Reep did not live on post, but commuted each day from Rolla, and he never saw a high ranking officer like General Grant either! $!^{18}$

What else we know about the lives of these black officers concerns racial problems and would indicate that they experienced a great deal of frustration. A letter to the NAACP written on behalf of one black engineer officer stationed temporarily at Fort Leonard Wood provides a unique insight into the black officer experience. Second Lieutenant William F. Jones was one of the few black engineer officers in the Army who held an engineering degree in civilian life (note this letter was alluded to above and asserts that their were only 40 black engineer officers in the Corps around November 1942). Commissioned on May 20, 1942, at Fort Belvoir, Virginia, Lieutenant Jones was quickly posted to Fort Leonard Wood. In August he was assigned as Troop Train Commander for 240 black troops heading to Camp Polk, Louisiana--a mission he accomplished with no problem. However, when he and five enlisted men attempted to return to Fort Leonard Wood, they were denied Pullman accommodations in Shreveport, Louisiana. He sent two men ahead immediately by coach, and eventually he got the rest back to Fort Leonard Wood, but not before he and the remaining three were accosted and threatened by local police. The police harassment came about after the train conductor took exception to Lieutenant Jones wearing his sidearm (standard procedure for a Troop Train Commander). The local M.P.s refused to do anything about it, so the irate conductor called the city police. After returning to Fort Leonard Wood he and 14 other black officers were ordered to Fort Huachuca, Arizona.

At Fort Huachuca, Lieutenant Jones ran into more racial slights. While working for a Colonel on one project, his Company Commander requested he begin another. He was unable to perform the latter because he was not only busy doing the first, but could not secure the necessary equipment to begin the second project. Meanwhile, a sergeant under his command failed to do his job and, possibly to cover his own failures, jumped the chain of command by complaining to the Company Commander that Lieutenant Jones was inefficient. Then, a white Lieutenant complained to the commander that Jones had failed to salute him at headquarters. Adding to Jones' problems, his white fiance visited him and he became embroiled in controversy at the Hostess House. One evening he, some fellow officers, and their girlfriends got together in her room, drank sodas and had a good time. Unfortunately the next day, the maid, upon entering her room found the extra bed messed-up from their party and assumed that Lieutenant Jones had slept over the previous evening. Lieutenant Jones soon found himself formally charged with: 1) creating a disturbance in Louisiana; 2) inefficient handling of men, because the sergeant had complained that Jones had a "chip on his

\footnotetext{
${ }^{18}$ Letter, Mr. Edward Reep to Steven D. Smith, 26 July 1998, (Columbia, South Carolina:on file, SCIAA).
} 
shoulder thinking about the status of his race." ${ }^{\prime 19}$ The outcome of his situation is unknown, but the Lieutenant seems to have endured just about every form of prejudicial behavior black officers could experience during the war; contempt from civilian whites fearful of a black man with authority, insubordination from soldiers below him, and harassment from above and from civilians. It would have taken great strength of character not to develop a 'chip-on-the-shoulder' attitude.

Black officers at Fort Leonard Wood messed with the white officers, but had separate housing facilities at least part of the time (see Chapter IV) and, of course, a separate social club. Messing with white officers did not mean that black officers were treated as equals, and it is obvious that there was considerable tension between white and black officers in the ERTC that eventually came to a head in the officer's mess in 1945. In a series of incidents between July 20 and 23, white and black officers clashed over the where blacks sat in the officers' mess. Records of the investigation and letters exchanged between the NAACP and the Army offer additional insights into the segregated lives of black officers at Fort Leonard Wood. ${ }^{20}$

The incidents began when a black officer seated himself at the center table in the mess hall across from a white officer and his wife already seated. Apparently, "by custom long standing" as the investigation report stated, black and white officers had eaten at separate tables in the integrated mess. The white officer told the black officer that a seat was "reserved for him elsewhere," or according to an affidavit signed by two witness, "told ... to go in the corner where he belonged." The black officer responded that there was no place reserved for him, that is, he could sit where he wanted. The white officer then attempted to bring the Battalion Commander into the argument, but the Battalion Commander refused to take sides saying nothing could be done. The white officer returned to his seat and no more was said between the two officers. But other black officers continued to seat themselves with whites for two or three days afterward. Before tensions could get out of control, black officers were called to a meeting where they were informed by the Group Commander to eat at separate tables "not as a matter of segregation, but to avoid the continuation of a series of incidents which might have unfortunate results." This action was duly reported to the ASFTC Commander who approved the steps taken but immediately ordered an investigation and as a result the order was rescinded a week later. ${ }^{21}$ In the ASFTC Commander's report he stated that the "entire case produces a presumption of collusion among the Negro officers"

${ }_{19}$ Letter, H. Leonard Richardson, Attorney at Law, to Mr. Walter White, NAACP, 24 November 1942. Papers of the NAACP, Part 9, Series B, "Discrimination In The U.S. Armed Forces, 1918-1950," Soldier Complaints, Reel 12, 0564 (University of South Carolina, Columbia, microfilm, Thomas Cooper Library).

20 Letter, Daniel E. Byrd, Executive Secretary, NAACP to The Inspector General, United States Army, 28 July 1945; Memorandum, Colonel Andrew R. Duvall through Brigadier General D.O. Elliott to Commanding General, Fort Leonard Wood, 10 August 10 1945; Letter of Colonel John Nash Executive Deputy Chief of Staff for Service Command to Mr. Daniel E. Byrd, 18 August 1945; Affidavit of Yvonne Bell and Florence DeLavallade undated, ca. July 1945 Record Group 107, Records of the Office of the Secretary of War, Judge Hastie Files (College Park, Maryland: National Archives II).

${ }^{21}$ Memorandum "Seating Arrangements in 7th Group Officers' Mess, Brigadier General D.O. Elliott to Commanding Officer, 7th Group ASFTC, 31 July 1945 (Fort Leonard Wood, Missouri: on file, History Office, U.S. Army Engineer Center). 
mentioning that the black officers (around ten at the time) had avoided the mess hall altogether after being ordered to sit at separate tables. They returned after the order was rescinded. No further disciplinary action was taken against either the whites or blacks; the Commander feared that the black officers would use such action to "pose as real or fancied martyrs of racial intolerance."

But in fact they already had. They or someone else filed a complaint with the NAACP and the ASF ordered further investigation, which was forwarded to the NAACP. The report by the ASFTC Commander closed the incident as far as known, but one comment in the letter of the NAACP is of interest. The letter acknowledges that the order for black and white officers to eat at separate tables might have been a sincere attempt to avoid conflict, but that as a result of the order "the morale of the Negro Officers has reached a new low ebb." Obviously, this incident was not the first conflict between white and black officers at Fort Leonard Wood, and that low morale and dissatisfaction among the black officers was what led to the instigation of the mess hall confrontation in the first place.

\section{Summary}

As is evident, the experiences and history of the black officer corps at Fort Leonard Wood is almost totally unknown. What is known centers around racial incidents toward the end of the war. The mess hall confrontation can be viewed as a typical incident caused by the complexity of black officer life in World War II. They were segregated in this case not by Army policy but by custom. The problem of providing facilities for these frankly undesired men created a situation which will be further explored in the next chapter. 


\section{CHAPTER IV: FORT LEONARD WOOD AND THE PROBLEM OF SEGREGATED FACILITIES}

\section{Introduction}

If the existing documents discovered during the course of this research are representative, then it is clear that one of the most vexing, continual, and time-consuming problems facing the ERTC in its mission of turning out African American engineer soldiers at Fort Leonard Wood was the Army's segregated facilities policy. Dealing with the facility problem seems to have influenced all aspects of ERTC functioning when it came to black soldiers. ${ }^{1}$ Initially, the need for segregated facilities influenced installation design. Not only were separate housing and recreational facilities needed but also some separate training facilities became necessary, and when facilities like firing ranges were shared by whites and blacks, segregation created scheduling problems for trainers. Segregated facilities aggravated the quota problem, both that of incoming draftees and outgoing soldiers, which was difficult enough to control and schedule. Off-post, segregation created the necessity for separate recreational facilities in a rural community unaccustomed to blacks in large numbers. This chapter focuses on the facilities problem at Fort Leonard Wood during World War II in light of Army policy. Central to this project's research goals is, of course, the circumstances that led to the Black Officers' Club creation and its subsequent use. Indeed, Building 2101's initial construction and later assignment as a Black Officers' Club was a direct manifestation of a combination of the Army's segregated facilities policy and long standing Army traditions.

\section{The Construction of Fort Leonard Wood}

Fort Leonard Wood was constructed on an upland plateau between two beautiful deep-cut winding rivers, the Big Piney and Roubidoux Creek, in the central Missouri Ozarks. It was a land previously settled by white Protestant, independent small-farm owner-operators who had first arrived in the early 19th century. They were poor, proud, and hardened by years of working its infertile soils. A land scantly populated throughout its history, the Army probably displaced only around 800 people when it purchased 67,757 acres for the installation. ${ }^{2}$ About 16,000 acres had already been purchased by the Forest Service during the Depression, and except for some Civilian Conservation Corps (CCC) and tourist camps, it was open, stubby, and undeveloped.

The plan originally authorized by Congress was that the Army's new 7th Corps divisional training center and ERTC would be at Leon, Iowa. There the Army sent its private contractor

\footnotetext{
1 There are a large number of training manuals available at the National Archives, so the bulk of the known documents are concerned with training. However, at a subject level, the most prevalent topic among existing documents concerns some aspect of African American facilities needs and/or associated problems.

${ }^{2}$ Smith, Made it in the Timber; Roberts, "The Engineer Replacement Training Center," p. 78.
} 
architects, Alvord, Burdick, Howson of Chicago to begin work. But soon it was discovered that the water table had dropped and obtaining water would be prohibitively expensive, so the Army announced on October 1, 1940, that it would move its new 7th Corps training area to Missouri.

From a planned 23,000 man camp in Iowa to a 35,000 man camp at Fort Leonard Wood, the project became too large for one contractor, and four firms (W.A. Klinger and Sons, Arthur H. Neumann Brothers, Inc., Western Contracting Corporation, and C.F. Lytle Company) joined together into a conglomeration called the K.N.W.L. Company to share the construction responsibilities. Their colossal effort to bring the necessary raw materials to this isolated region and construct a fort there is difficult to comprehend today. Yet it is overshadowed by the fact that Fort Leonard Wood was only one of numerous installations being constructed across the country at that time, for the entire nation was preparing for war and in a building frenzy in 1940. However, in about seven months the four firms planned and completed an entire cantonment area containing 1,600 buildings, 62 miles of water and sewer lines, and 58 miles of roads. They used 75 million board feet of lumber, 80,000 cubic yards of concrete, 52 miles of vitreous and concrete tile, 2,500 utility poles, and 2 million feet of wire in this amazing effort. ${ }^{3}$ Close to 46,000 people were hired in some capacity or other in the construction effort.

The van of the construction teams arrived in late November 1940, and by December land purchases were initiated. December 11th marked the first excavation work, and by early January the first barracks was ready. However, excessive rain during December and January made roads impassable and the planned arrival of troops by the first of the year had to be delayed. ${ }^{4}$ The area's isolation caused additional delays--the nearest town of Waynesville was populated by only around 500 people. Sleepy Waynesville did not have nearly the infrastructure to support some 30,775 construction workers, who eventually had to be camped and housed throughout a 50 mile radius surrounding the fort. Newburg, only slightly larger than Waynesville and 26 miles away, became the focal point where the administrative offices were established along with the nearby Alhambra Grotto resort. But Newburg was also the closest railroad terminus when construction began and an obvious place for a construction headquarters. While some laborers frantically worked to build a railroad spur to the fort, others worked to improve and construct better roads to the site. Meanwhile, some 7,000 vehicles a day slogged along historic Route 66, the only existing main road, in an attempt to keep workers in supply. The railroad spur into the fort was finally completed around mid-April 1941.

Getting sufficient power to the site was yet another problem. The architects and the Construction Quartermaster Command decided to purchase electrical power from a 'local' utility. This still meant the construction of a temporary and later permanent line from the Union Electric

\footnotetext{
${ }_{3}$ Smith, Made it in the Timber; Roberts, "The Engineer Replacement Training Center," pp. 78-84; Anonymous, "The Construction of Fort Leonard Wood" fact sheet (Fort Leonard Wood, Missouri: on file, History Office, U.S. Army Engineer Center); Herman, "Fort Leonard Wood, Missouri," p. 110.

4 Anon., "The Construction of Fort Leonard Wood."
} 
Power Company 20 miles away. This line was completed in February. Numerous construction delays and challenges meant that troops did not arrive until May, and for that reason Fort Leonard Wood's ERTC began to take shape at Fort Belvoir, Virginia.

Fort Leonard Wood's cantonment was about six square miles, three miles north-south by two miles east-west, much of which is still preserved today (Figure 4.1). ${ }^{5}$ Within its center was a 7,000 $x$ 3,000 foot open parade ground, and around that were arranged facilities for the following military units:

1) The Sixth Division, located entirely west of Iowa Avenue.

2) The 72nd Field Artillery Brigade (National Guard), south of South Dakota Avenue.

3) The Engineer Replacement Training Center, east of Nebraska Avenue.

4) Post Headquarters, white and colored Army Troops and the Hospitals, all north of North Dakota Avenue.

5) The Warehouse area, situated east and north of the ERTC at the Intersection of Minnesota Avenue and First Street. ${ }^{6}$

Within this initial design the Military Police Headquarters was west of the Post Headquarters along Headquarters Avenue, the white Quartermaster troops were on "N" Avenue, and the black Quartermaster troops were located northeast of the Warehouse area. An officers' compound, used as extra quarters, was located on Missouri Avenue near the fort's entrance. Today this location is the site of either the guest house cottages on Community Drive or the entrance to the Engineer Center. Army Ground Forces black troops, as opposed to those to be trained in the ERTC, were located on the northern portion of the post, the black troops east of the white troops, on the east side of North "I" Avenue.

At the beginning of training, black troops in the ERTC were bounded by Army Ave, First Street, Laundry Street, and East 2nd Street, with their Headquarters some 700 feet south of their area along East Third (Figures 4.1,4.2). Today the main streets in this area are still aligned as they were during WWII. Building 2101, the Personnel Adjutant's Office and soon to be the Black Officers' Club sat as it does today at the corner of Replacement and East Second Streets. A large ravine separated the main area from headquarters south of Building 2101, but in between was Building 2100, which would be used as the black officers' barracks. The rolling terrain in this area ${ }^{5}$ A comparison of the WWII period and modern fort maps indicates only a few road changes from the original WWII layout and many street names have been retained. From North Dakota Avenue along the north edge to Nebraska to the south, and from Indiana west to Oklahoma on the east, few modifications have been made. Among some minor road changes are that west 4th now crosses the parade field to Replacement Avenue, Constitution now bisects the old WWII parade ground, and Illinois Ave also intrudes on the old parade ground. North of First Street in the location of the old hospital grounds the Engineer Center now stands. The Soldier Service Center is now located on the north end of the old parade ground. The area northwest of North Dakota was not developed during the war. There have been street modifications south of 4th Street also. However, overall, the center of Fort Leonard Wood retains much of its WWII landscape.

${ }^{6}$ Robinson, "Landscape Development Report," p. 2. 


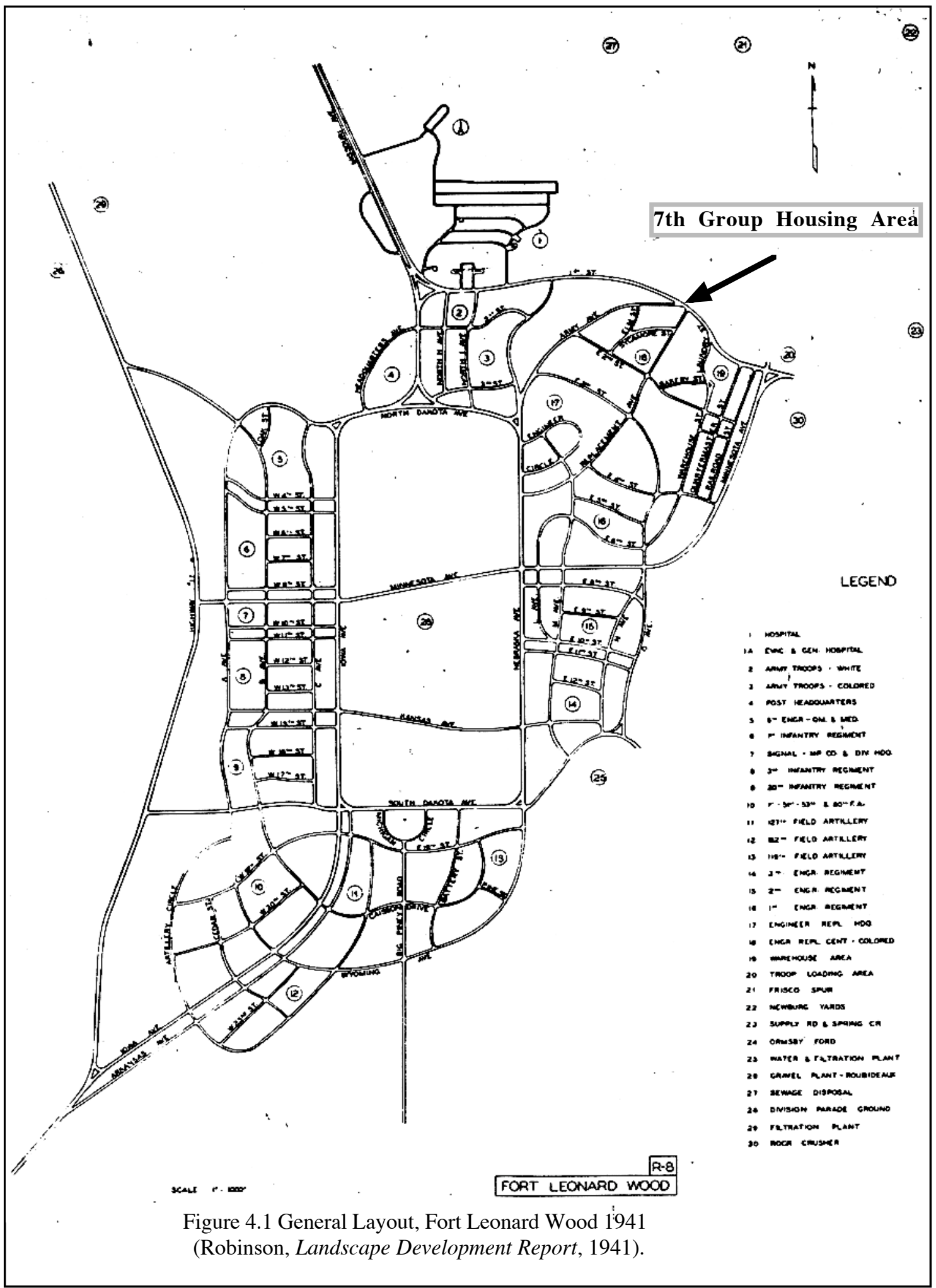


made orderly, military-like, rectangular formations and straight streets unfeasible. But the landscape plan noted that "A high, heavily wooded knoll furnishes the site for the location of this regiment, one of the most beautiful in natural scenery of the entire camp." ${ }^{17}$

Although picturesque, the location of the black housing facilities had some clear disadvantages. A training progress report of July 12, 1941, complained that:

The arrangement on the ground of the barracks and training areas is far from ideal and results in one of the greatest obstacles to proper training. The warehouse area, coal and oil storage yards, and railroad yards, project into the Engineer Replacement Training Center Area. This directly results in the supply traffic of the entire post traversing through the heart. . . or passing on flank roads adjoining the barracks. Troops are delayed by traffic, movements of troops from barracks to training areas on the north east are blocked by the warehouse area. ${ }^{8}$

Another cantonment design problem of special interest was that headquarters and administrative buildings were initially "widely spread" according to General Grant. He recommended that a "central administrative building to house all of the headquarters offices and the personnel and classification offices would result in more efficient administration and better coordination of training." 9 This request had already been made for the headquarters building, as it was included in the request for 16 to 20 additional barracks (for 1,250 or 1,000 additional men), four or five company administration and supply buildings, four or five mess halls, four or five day rooms, and two classrooms due to the necessary ERTC expansion to meet manpower needs. ${ }^{10}$ Despite receiving disapproval for a major expansion of facilities in March 1941, the ERTC eventually did centralize ERTC headquarters and this may have had ramifications regarding the Black Officers' Club (see below). ${ }^{11}$

Besides problems with cantonment layout, classroom facilities at the new post were not adequate either. The classrooms were too small, lighting and ventilation were poor and the central posts in these rooms blocked student observation. Despite building additional classrooms, this problem remained throughout the war. Yet another problem was far too few day rooms. To compensate, the battalion recreation halls were filled with recreational equipment like pool tables, and this impacted training, making it impossible to use these large buildings as training classrooms. When the ERTC mission expanded, the problem of a lack of classrooms was 7 Ibid., p. 48.

${ }^{8}$ Brigadier General U.S. Grant 3rd, to the Commanding General Seventh Corps Area, "Training Progress Report," 12 July 1941 (Fort Leonard Wood, Missouri: on file, History Office, U.S. Army Engineer Center). 9 Ibid.

${ }^{10}$ Major Louis J. Claterbes, to the Assistant Chief of Staff, Washington D.C., "Increase in Housing Facilities at Fort Leonard Wood to Provide for Development Battalion," 7 June 1941 (Fort Leonard Wood, Missouri: on file, History Office, U.S. Army Engineer Center).

11 "Training Facilities, Seventh Corps Area, Engineer Replacement Training Center," 24 March 1941 (Fort Leonard Wood, Missouri: on file, History Office, U.S. Army Engineer Center). 


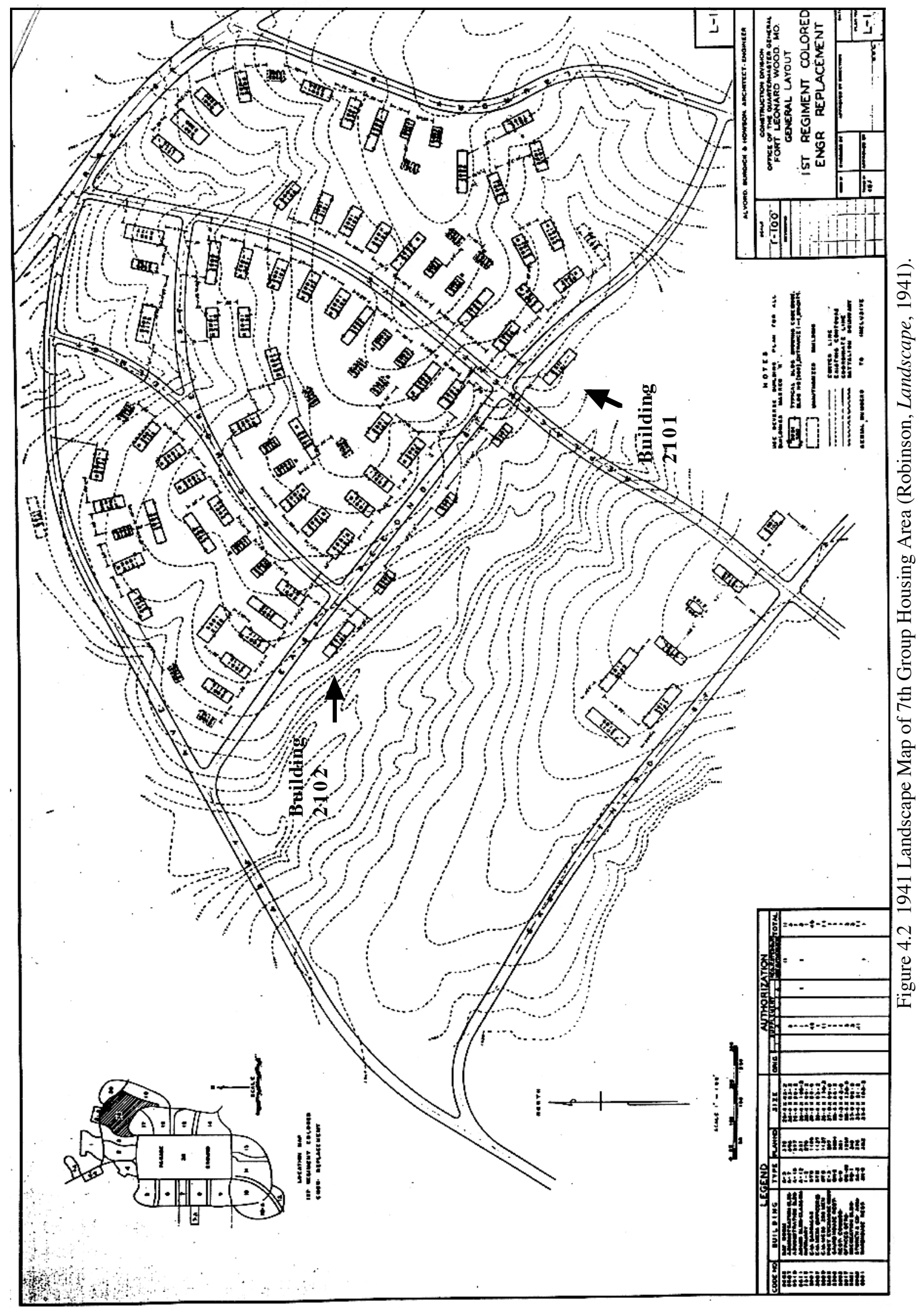


temporarily solved by erecting pyramidal tents. In 1944, the ERTC was faced with multiple training cycles, specialist training, and manpower pools awaiting reassignment in refresher courses. The center created two eight-hour instruction shifts, mess halls served four times a day, sick calls were scheduled twice a day, and at the same time men were arranged so as to keep some unit cohesion within housing arrangements (Figure 4.3) Meanwhile, the theaters had morning performances, and service clubs were made available during the daylight hours. ${ }^{12}$

Traffic, inadequate classrooms, and dispersed administrative buildings were problems for all ERTC units at the beginning of training, but the 7th Group (black) had an additional problem. This group was housed too far from the parade ground for its efficient use in training. Too much time had to be spent marching to and from the parade ground where close-order drill and calisthenics could be performed. Black troops were forced to practice drill and calisthenics on macadam roads in their barracks area; a decidedly uncomfortable ground for exercise, and the loose stones made precision drill impossible. ${ }^{13}$

Beyond the cantonment the uplands were left mostly as a wild semi-forested region, excellent for maneuver training. A 12,000 yard artillery range was built, along with two antiaircraft ranges, a 1,000 foot range, practice and qualification bayonet ranges, four grenade courts, a gas chamber, a demolition area, and three 40 target "A" ranges. The number of ranges and training areas continued to increase during the course of the war. Other facilities included an airfield with a 5,000 foot runway, and 500 family dwellings for noncommissioned officer families. ${ }^{14}$ With two rivers bracketed by high cliffs, the installation was also perfect engineer training ground. The Army built a dam across the Big Piney to create a pool for floating bridge training. Beyond the post, the region's rural character was another asset to training. Local roads had so little traffic they were ideal for long route marches. But there was some more poor planning. The railroad constantly bringing in supplies was built too close to a target range. Training had to be stopped when trains passed by.

When the first troops arrived, post training facilities were unfinished and the trainees found themselves on construction teams rather than training, along with a few CCC laborers. These troops completed clearing tactical areas, provisioning store houses, building latrines in the tactical areas, constructing a camp at the floating bridge area, clearing fields of fire on combat ranges, constructing a cross-country obstacle course, clearing trails, and even constructing a few miscellaneous buildings. Meanwhile back in the cantonment, trainees assisted in landscaping, laying sidewalks, painting barracks, creating roads to kitchens, and paving roads. ${ }^{15}$ Informant Mr.

\footnotetext{
${ }_{12}$ Anon. "Cards,"; Training of Fillers, Replacements, 6 March 1941-30 June 1944; Training of Fillers, Replacements, 1 July 1944- 31 December 1944.

${ }_{13}^{13}$ Ibid.

${ }^{14}$ Ibid.; Herman, "Fort Leonard Wood, Missouri," p. 110.

${ }^{15}$ Grant to Commanding General, "Training Progress Report,"; OCMH, Training of Replacements, Fillers, and Cadres, March 1941-June 1944, p. 3.
} 


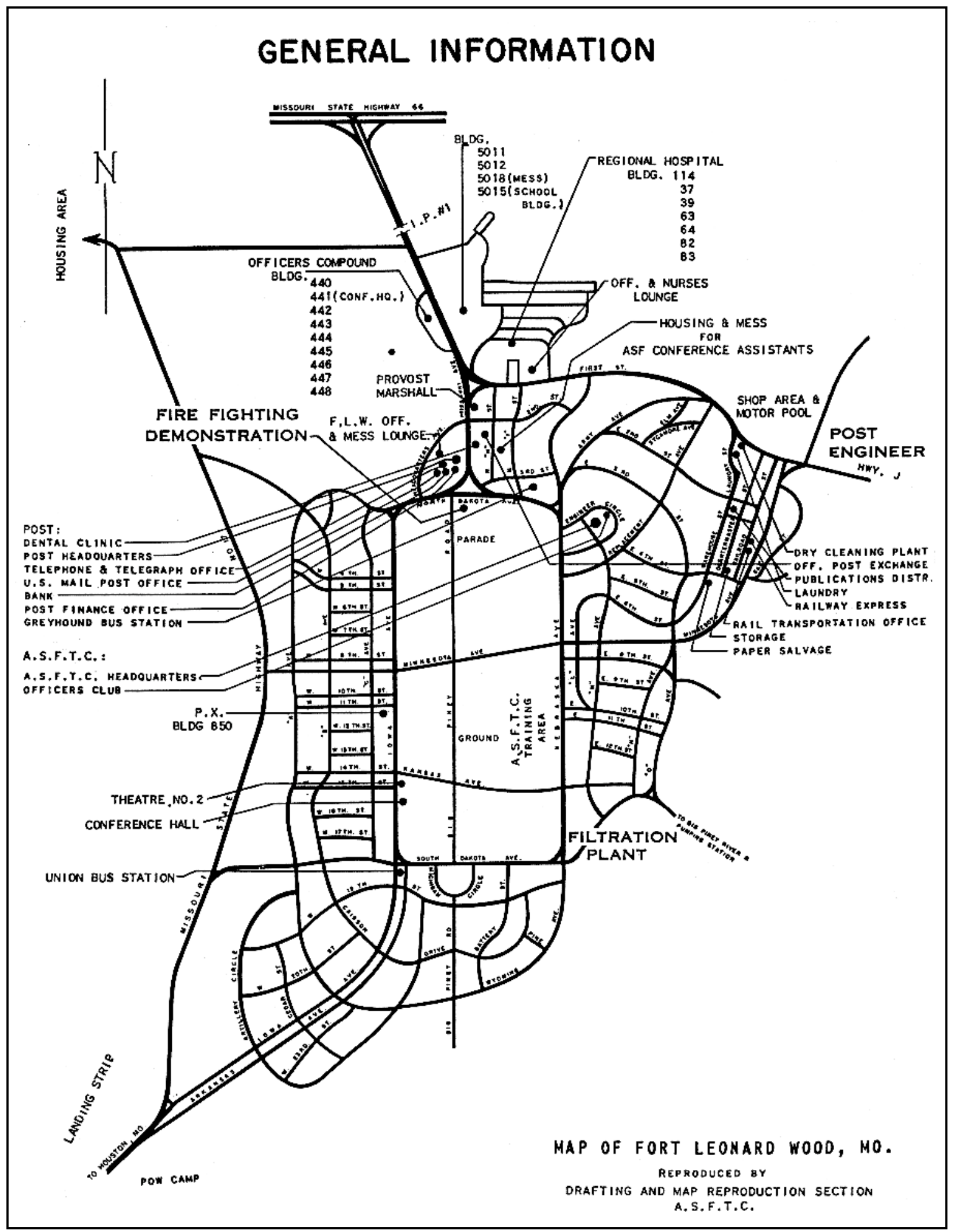

Figure 4.3 Fort Leonard Wood and Facilities, 1944 ("Fort Leonard Wood, Missouri," Repairs and Utilities Activities, U.S. Army Service Forces, Service Command Conference, 1944). 
Perry Cox arrived in May 1941 and found himself the first week "grubbing-out" the weeds around his barracks. Even in July 1941, some facilities were not completed, including storage buildings and mess halls at the floating bridge area. Also additional clearing of tactical areas, and grading of the parade ground was needed. Indeed, construction was really not completed until the autumn of 1942 , as a result of the program expansion and manpower needs. ${ }^{16}$

The initial training program in 1941 was obviously hindered by the unfinished post, diverting trainees to camp preparation and to the tedious process of receiving, inventorying, and storing large amounts of supplies pouring into the new camp. Adding to the list of deficiencies was a lack of recreational facilities made larger by the planned expansion later that summer. The lack of recreational facilities upon opening was critical enough in General Grant's view for him to emphasize their early construction in any future mobilization plans. Long after his ERTC command, in March, 1945, General Grant was asked for his input regarding the development of "sound doctrine for the training of Engineer replacements." Grant's first comments were directed straight to the facilities problem. Morale, or "esprit de corps" he felt, was enhanced at his ERTC as a result of two facts. The first was that being an engineer meant that they were part of a technical corps that had to work harder and were superior to other troops. The second was that this attitude was manifested and "enhanced by the special attention paid to the prompt provision of social and recreational facilities for the many hours when training was not actually being carried on." General Grant continued this point by emphatically stating:

In a location so isolated as Fort Leonard Wood this was a matter of prime importance, and was especially difficult because the approved program of construction left the building of service clubs, officers' clubs, and moving picture theaters in the ERTC area till long after the Training Center was established and functioning. While substitutes were improvised, which met the emergency well enough, the point is important enough to deserve attention in establishing new training centers. ${ }^{17}$ [emphasis added]

Of course, the policy of segregated housing and training facilities spilled over into the area of recreational facilities, despite the Army's reluctance to get involved at the policy level with the problem of how black and white soldiers would spend their off-duty hours.

\section{Segregated Lives, Segregated Facilities: African American Enlisted Men At Fort Leonard Wood}

The Army policy of segregated housing for African American troops caused mobilization and training complications at installations and camps across the nation. Because so few blacks were in the Army at the war's beginning, camps and forts already built were not designed for, nor could they be adapted readily to separated, self-functioning housing, recreational, and in some cases, ${ }^{16}$ OCMH, Training of Replacements, Fillers, and Cadres, March 1941-June 1944, p. 10.

${ }_{17}$ Letter from Brigadier General U.S. Grant III, to Colonel H.W. Schull, Jr., 14 March 1945. MS344, U.S. Grant III Papers, (Washington D.C.: the Historical Society of Washington). 
training areas for black units. Even when there were empty or underutilized barracks and recreational facilities awaiting troops, these spaces were not necessarily adaptable for housing black troops because of imposed black unit size restrictions. As noted, at the beginning of the war black units were restricted to brigade or smaller units. Traditionally, military units had always been housed by unit to maintain unit cohesion, control, and to build morale. Installation housing was designed with this in mind. However, where black units did not correspond in size and complexity to white units, housing and recreation facilities would either be crowded or underutilized in order to maintain the policy-driven separation of white and black units. Such complications often resulted in installations housing their newly formed black units in make-shift areas, after white troops had been fully housed. If there was no space available, they were tented until separate housing could be built. ${ }^{18}$

As blacks arrived at installations across the nation, installation commanders also had to deal with local community attitudes toward black soldiers. One of the most common concerns was that black soldiers at an installation would reach a percentage on any one installation greater than ten percent of the total military population. There was a common belief that an installation would have difficulty controlling such a large number of black troops. Through 1941 and 1942, the Army received numerous protests from local communities about posting black troops in their neighborhoods. By November, 1941, the protests became so prevalent that General George Marshall asked his staff to take another look at the planned black troop distribution, with the idea of possibly revising plans so that blacks would be posted only at installations with a nearby large black population. ${ }^{19}$ In January, 1942, his staff reported that further shifting (apparently this had been tried) would serve no useful purpose. They did recommend that in the future, the size of the local black community be one of the prime determinants in stationing black troops, and that wherever possible, northern blacks be inducted into northern stations to avoid the growing problem of northern blacks in southern regions. With the exception of Fort Huachuca, Arizona, where the all-black 92nd Division was training, the prohibition against stationing any black unit larger than a brigade at any one installation was reinforced by this study. ${ }^{20}$

Thus, great pains and planning time was being expended as a result of segregation policies. Ulysses Lee summed up the challenge of housing blacks:

Purely military considerations played but small part in determining the location of Negro troops in the early period of mobilization. The main considerations were: availably of housing and facilities on the post concerned; proportions of white and Negro troops at the post; proximity to civilian centers of Negro population with good recreational facilities that could absorb sizable numbers of Negroes on

\footnotetext{
${ }_{18}$ Lee, Employment, pp. 97-99.

${ }^{19}$ Fort Leonard Wood responded to this survey, see Chapter 2.

${ }^{20}$ Ibid., p. 103.
} 
pass; and the attitude of the nearby civilian community to the presence of Negro troops. ${ }^{21}$

The answer to the black troop facility problem eluded major command headquarters throughout the war and a final, clear policy was not forthcoming. The solution was left to the local installation commander, along with dealing with any local population hostility toward blacks. As Lieutenant General Lesley McNair, Commander of the Army Ground Forces explained, the only answer was strong local leadership "who can forestall racial difficulties by firm discipline, just treatment, strenuous training, and wholesome recreational facilities."22 General McNair's comments are, of course, reminiscent of those of General Grant in handling the racial problem. Keep the men busy with rigorous training and provide ample recreational outlets.

The need for "wholesome recreational facilities" was another separate, but related, consideration besides housing with complications of its own. While the Army attempted a coherent segregation policy concerning housing at the beginning of the war, recreational facilities were a slightly different situation. Recreational facilities for blacks would be determined by their representation at various installations ". . as if the colored contingent formed the garrison of a separate camp." In other words, if a black company was stationed at an installation, they would have separate recreational facilities normally associated with a company-sized unit, if a battalion was stationed at an installation, it would have recreational facilities to serve a battalion. Thus, although there was no official policy about separate recreational facilities, the housing policy of unit segregation by race carried over into unstated policies regarding recreational facilities. Separate housing had some rationale when observed from the viewpoint of unit cohesion. Since units were housed separately by tradition and policy to enhance unit cohesion, unit segregation fit without reference to segregation by race. But segregated recreational facilities stood out more clearly as racial discrimination since usually they were shared by many units at a single post.

Complaints from black troops about separate recreational facilities came rapidly to the War Department, and its first response was to prohibit the designation of "colored" and "white" facilities on posts where blacks were in the majority, and then in March, 1943, to forbid the designation of any recreational facilities by race at any military post. In theory, after this order, blacks were allowed to use the same facilities as the white soldiers but at different times. ${ }^{23}$ However, this policy was put in place far too late, since by then black recreational facilities were either already built (as at Fort Leonard Wood), or were already segregated by unit. Thus, in practice, this order had little effect. The only cosmetic change was that facilities were designated by number instead of "white" or "colored." For instance, at Fort Leonard Wood, the "colored" service club for enlisted men was Club No. 3. Some installations simply ignored the order outright.

21 Ibid., p. 100.

22 Ibid., p. 105.

${ }^{23}$ Buchanan, Black Americans, p. 76. 
Being a new installation, Fort Leonard Wood had the initial advantage of being able to plan and design, to some degree, for the construction of both segregated black housing and recreational facilities. Separate housing was built both at the ERTC and in the 7th Corps area. Housing problems at Fort Leonard Wood then, came primarily as a result of expansion. As noted previously, there was no local black community infrastructure. But by 1943, the recreation problem seems to had been overcome by arranging travel to the larger cities so that the black troops could find support and friendship among their own people. From the Army engineer's perspective, black housing and recreational facilities at Fort Leonard Wood met the needs of time and circumstance very well. Housing and recreational facilities were adequate in number (not withstanding the "flow" problem), segregated, and considered on par with the facilities provided to white troops. Thus, the engineers turned to Fort Leonard Wood to train all black engineer troops from that point on, solving the segregated facilities problem at Fort Belvoir, Virginia and Camp Abbott, Oregon.

Indeed, planning facilities for black troops at Fort Leonard Wood began early. An April 1941, report indicates that on Nebraska Avenue there was a theater for the black troops already constructed and awaiting the arrival of the first black soldiers. There was also a hostess house and service club planned along that same street. The location of these facilities would be convenient to both the black engineers at the ERTC and other ground units. ${ }^{24}$ When exactly the service club was completed is not known, but given the comments of General Grant, above, it is likely that they were not available when the first black troops arrived in May. However, by December 26, 1941, a construction report indicates that there was one service club, one theater, and one guest house available for the black troops. ${ }^{25}$

In June 1942, the famed black Brigadier General Benjamin O. Davis inspected the post and his report provides some insights into facilities for blacks at that time. Davis reported that the troops were "comfortably housed in cantonment barracks," and they had excellent messes. The grounds were clean. A service club, branch exchange, theater, and small hostess house were available. Davis went on to report that the hostess house, with only six rooms, was entirely inadequate for the number of black troops on post. Hostess houses, or guest houses, were used to temporarily house overnight guests visiting soldiers. In an isolated area such as Fort Leonard Wood, and without a black community available for support, the men's wives and parents would have had a difficult time finding a place to stay when they visited. This problem then was very important to black morale. Two letters exist which indicate that the general's recommendations concerning the guest house were considered, but it is not clear that they were acted upon. Both letters indicate that additional guest houses would be provided in accordance with War Department construction policy, and that another study of recreational facilities for black troops

\footnotetext{
24 Robinson, "Landscape Development Report," p. 55.

25 "Recreational Facilities For Negro Troops," 26 December 1941, Record Group 107, Entry 91, Box 242, (College Park, Maryland: National Archives II).
} 
was being made. ${ }^{26}$ The study's results are not known, which is extremely unfortunate as its timing implies that it might well have mentioned the need for a black officers' club. In any case, General Davis also noted that there were, as yet, no railroad facilities for passenger travel to cities like St. Louis, although the matter had been taken up with the railroad in March of that year. ${ }^{27}$ Eventually, these services were provided.

The continuing troop scheduling or "flow" problem was exacerbated by the segregated housing policy and it began almost immediately at Fort Leonard Wood. A letter from the installation to the Adjutant General in September 1941, demonstrates what would become a typical situation where segregated housing policy was upsetting training calendars. The ERTC was scheduled to receive 1,760 white trainees in December 1941, for a total of two black battalions and eight white battalions. But housing at the fort was based on seven white and three black battalions. A solution was proposed which would substitute some units for others. However, this solution was untenable:

Such a substitution is not practicable. There are barracks at this station for 7 battalions of white trainees in one area, and for 3 battalions (one battalion less one company) of colored trainees in another area well separated from the area for white trainees. Further, the enlisted cadres of 3 battalions . . . are for colored troops. ${ }^{28}$

The on-going housing problem did calm briefly during 1943, but with the ERTC mission change from loss replacement training to both loss replacement and pre-activation training around May 1944, it rises again, creating what General Garlington called a "critical housing condition." In this case, there was about to be a "48 man excess" in the scheduled inflow of black enlisted men-that is, 48 men in excess of the maximum emergency housing capacity allowed by the ASF, which was 94 men per barracks or 40 square feet per man. These were crowded conditions! Further, General Garlington had no idea how many additional black soldiers might arrive from other commands which had been authorized by higher ASF headquarters. General Garlington stated that excess black enlisted men might cause them to be housed with white troops and:

It is considered vitally important that future shipments do not necessitate the housing of negro personnel in the area occupied by white soldiers. The present arrangement for housing negro personnel. . .fosters a high state of morale among both white and negro soldiers and minimizes the ever-present racial problem. Any alteration of this arrangement would greatly increase the disciplinary

\footnotetext{
${ }^{26}$ Letter, Chief, Ground Troop Section to Colonel Garlington, 30 June 1942; Lieutenant General Paul W. Thompson to the Inspector General, 4 July 1942 (Fort Leonard Wood, Missouri: both on file, History Office, U.S. Army Engineer Center).

${ }^{27}$ Davis to the Inspector General, 22 June 1943, p. 2.

${ }^{28}$ Letter quoted in Lee, Employment, p. 99.
} 
problem and would create opportunity for 'incidents' which could easily reach serious proportions. ${ }^{29}$

General Garlington's plea was heard and it was agreed that once the Negro Dump Truck Companies which were being filled were at capacity, the flow of black enlisted into the fort would be reduced. Meanwhile, the immediate crisis was expected to be eased because the First through Seventh Service Commands were expected to request additional black men from Fort Leonard Wood. ${ }^{30}$

But again wartime conditions changed, and the problem of housing black soldiers came up the following year. During the period from January to July 1945, correspondence and memos flew between the ASFTC at Fort Leonard Wood, the ASF command center at Omaha, Nebraska, and the AGF also at Fort Leonard Wood. Although complex and difficult to follow, the basic problem was that Fort Leonard Wood was receiving too many troops, both black and white, for its housing capacity. The problem was greatest within the black troop area because the fort was expected to continue training black engineer troops that late in the war, and in fact, the percentage of black troops on post was expected to reach between 38 and $40 \%$ of post population. Meanwhile, AGF, which also had a few black units on post and was at first willing to share some space back in March, was now expecting an entire white division from Europe and it needed all its space. Again, the ASFTC asked for a reduction in the number of black troops coming in, and either more space from the AGF or authorization for additional construction. The final solution is again not apparent (although some black soldiers may have been shipped to Camp Crowder), but by late 1945, the problem was moot as the main concern became demobilization resulting from Japan's defeat. ${ }^{31}$

\section{Black Soldiers Off-Duty}

Overall, once recreational facilities were up and running, black soldiers at Fort Leonard Wood had a wide variety of off-duty possibilities for rest and recreation. As early as August 1941, a black soldier points out in a letter that they had baseball, basketball, softball, volleyball,

\footnotetext{
${ }^{29}$ Letter, Brigadier General Garlington to the Commanding General, Seventh Service Command, Omaha, Nebraska, "Negro Housing Capacity, Fort Leonard Wood, Missouri," 12 May 1944, RG 160, Army Service Forces, (College Park, Maryland, National Archives II).

${ }^{30}$ Letter, Major General L. Lutes, Director of Plans and Operations, ASF, to The Commanding General, Seventh Service Command, "Negro Housing Capacity in ASFTC, Fort Leonard Wood," 12 June 1944, RG 160, Army Service Forces, (College Park, Maryland: National Archives II).

${ }^{31}$ cf. Summary of Telephone Conversation between Lt. Colonel Jakaitis Director of Personnel to Major Hedahl, Military Personnel, ASF, Washington D.C., 23 February 1945 (Fort Leonard Wood, Missouri: on file, History Office, U.S. Army Engineer Center); Major General L. Lutes, "Utilization of Temporary Inactive Housing at Fort Leonard Wood," and attached memorandums, 10 March 1945, RG 160, Army Service Forces, (College Park, Maryland: National Archives II); Major Charles H. Flourney, Special Representative, OCE to Chief of Engineers, War Department, Memorandum "Activities Period 7 March-17 March 1945 Re: Negro Troops at Fort Leonard Wood, Missouri," (Fort Leonard Wood, Missouri: on file, History Office, U.S. Army Engineer Center); Major General Daniel Noce, Director of Plans and Operations, ASF, to the Commanding General Seventh Service Command, and attached memorandums, 25 June 1945, RG 160, Army Service Forces, (College Park, Maryland: National Archives II ).
} 
horseshoe pitching, and boxing available and that the recreation halls had radios, pianos, and, of course, pool tables. By the end of the war, they would have their own swimming pool, located behind the Black Officers' Club and barracks. The black enlisted men's recreation hall was called Service Club Number 3, and included a library and cafeteria. There was also a black NCO club located at the corner of East Second and Sycamore, Building 2102, just down the street from the Black Officers' Club at 2101 (Figure 4.2). Blacks also had their own post exchange. For religious services a chapel with an Evangelist and Baptist chaplain was available. ${ }^{32}$

There was an active program of organized sports at the fort. The installation newspaper, called the Fort Wood News, is full of articles about organized competition between post teams. Black teams and individuals were prominent in these articles. The ERTC's 7th Group competed well, having champion boxers, a baseball team, and a swim team. In these competitions, blacks competed against white teams, and even competed against teams off-post. In September 1945, the 7th Group won a post swimming and diving meet. Late in the war, the 7th Group's boxing gym started classes in judo and wrestling.

For the non-athlete there were other activities. For a short time late in the war, the 7 th Group had its own mimeographed news sheet called the Breeze, but it was closed in 1946 shortly before the entire post closed. ${ }^{33}$ There was also a camera club for black troops. In August 1943, the ERTC even opened an art studio where trainees could receive instruction or just paint on their own. All these activities were organized by a black Special Services Officer, who created and coordinated the dances, arts and crafts programs, and the sports activities. ${ }^{34}$

Issue after issue of the Fort Wood News lists the times and places where ERTC's black swing band was playing. This band was extremely popular and was asked to play for dances at the white clubs and at gigs off-base. One article called the band one of the post's best, and another states that the orchestra had to break into smaller groups to meet the demand for their services.

Off-post the regional community responded very well to black soldier needs with USO clubs and activities. Just off the main gate was a USO club for black soldiers, opened in March 1942, and

\footnotetext{
${ }_{32}$ The discussion concerning recreational facilities and recreational activities for blacks is culled from the 1943 and 1944 Fort Leonard Wood Telephone books, and the following issues of the Fort Wood News: "Camera Club For Colored Troops, 5 February 1943; "ERTC Colored Orchestra Is One of the Best," 12 March 1943; "Training 33rd Pugs," 4 June 1943; "ERTC Swingsters Park Service Club," 11 June 1943; "ERTC Art Studio Open to Trainees," 6 August 1943 (Fort Leonard Wood, Missouri: History Office, U.S. Army Engineer Center) and (Carlisle Barracks, Pennsylvania: microfilm, U.S. Military History Institute).

33 "7th Group Diamond Engineers," and "Schedules, Post Baseball League," Fort Wood News, 15 June 1945; "7th Group Wins Swim Meet." and "7th Group Pugs to Meet Crowder," Fort Wood News, 14 September 1945; "New Judo Course," 8 January 1946; "7th, 8th Gp. News Sheets Succumb This Week," Fort Wood News, 2 February 1946, (Fort Leonard Wood, Missouri: History Office, U.S. Army Engineer Center) and (Carlisle Barracks, Pennsylvania: microfilm, U.S. Military History Institute).

${ }_{34}$ "Response to Questions Posed by OCE Inspection," 17 April 1945 (Fort Leonard Wood, Missouri: History Office, U.S. Army Engineer Center).
} 


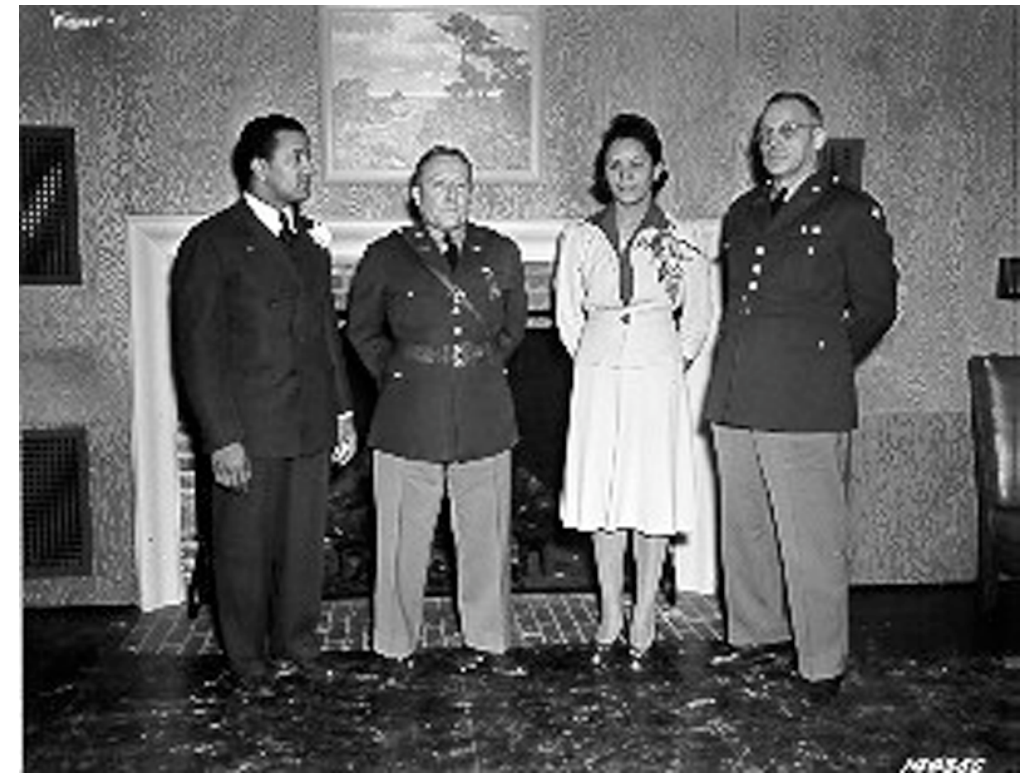

Figure 4.4 Dedication of the Route 17 USO Club, 8 March 1942. L to R: C. Sterling Chavis, club director, Lt. Col. F.H Ryder, Post Commander, Sarah Long, associate director, Lt. Col. Andy Lystad, Special Service Officer (courtesy, History Office, U.S. Army Engineer Center, Fort Leonard Wood, Missouri). although General Davis thought it was a little to far from the black housing for daily use it was a popular spot (Figure 4.4$).{ }^{35} \mathrm{It}$ was a two-story building and cost an amazing $\$ 90,000.00$. The club had 12 quarters for guests, game rooms, music rooms, and a snack bar. ${ }^{36}$ Beyond the immediate area, a black USO club was opened in Rolla at 102 W. 9th Street in February 1942, and one year later over 1,300 people attended its one-year birthday. There was another black USO club in Lebanon, Missouri (Figure 4.5). These service clubs organized special dances for the men to meet young women from

Jefferson City, Springfield and St. Louis who were bused-in. Although the dances were quite popular, many black troopers often preferred to go to the larger cities like St. Louis for long weekend trips where there was a larger black community. Busses and the railroad provided passenger service to these cities, and early in the war, the post organized week-end trips to Springfield and St. Louis. ${ }^{37}$ For instance, over the 1941 July 4 th weekend, a special train carrying 1,000 men from Fort Leonard Wood arrived in St. Louis, Missouri, for rest and recreation. Black men were given overnight accommodations at the black $\mathrm{YWCA}^{38}$ and in black churches and over the weekend attended a baseball game between the Kansas City Monarchs and Chicago Giants. That evening a special party was held at the $\mathrm{Y}^{39}$ Not every holiday was so successful. An interesting memo from the Deputy Commander to the Commanding Officer of the 7th and 8th Groups complains in 1945 that during Easter weekend, activities and transportation planned for the troops was inadequate. Apparently busses and trains were organized to allow soldiers to travel to St. Louis,

\footnotetext{
${ }^{35}$ A chimney still stands at this location just north of Fort Leonard Wood's main gate.

36 "USO Center For Colored Soldiers To Open Sunday," 12 March 1942, Pulaski County Democrat.

${ }^{37}$ Letter, Sewell; "ASFTC Thanks To Fort Road USO," 7 December 1943, "Invite 7th Group To Saturday Night Party," and "3 Dances Booked At Service Clubs," 2 February 1946 all Fort Wood News, (Fort Leonard Wood, Missouri: History Office, U.S. Army Engineer Center) and (Carlisle Barracks, Pennsylvania: microfilm, U.S. Military History Institute); Major General Daniel Noce to Assistant Chief of Staff, Liaison Division, RG 160, Army Service Forces, ( College Park, Maryland: National Archives II).

${ }^{38}$ This may be a typo in the news article and should read YMCA.

39 "1,000 Soldiers From Fort Wood Will Visit St. Louis," 3 July 1941 Rolla New Era (Fort Leonard Wood, Missouri: on file, History Office, U.S. Army Engineer Center).
} 
but the soldiers did not get the word..$^{40}$ The commander wanted to make sure activities next year were better organized and the word got out.

\section{Facilities For Black Officers and The Black Officers' Club}

The problem of black housing in the WWII Army was not limited to black enlisted men. Providing housing and recreational facilities for black officers was a separate challenge from the enlisted problem with a number of nuances unique to the officer corps. Most critically, the control of officers' quarters and officers' messes was traditionally left largely to the officers themselves:

The Army has always regarded the officers' quarters and the officers' mess as the home and the private dining room of the officers who reside and eat there. They are an entity within a military reservation which has always enjoyed a minimum of regulation and the largest possible measure of self-government. The War Department considers this to be a fundamentally correct conception. Both from the standpoint of practice of long standing and from the standpoint of propriety, the War Department should be most reluctant to impose hard and fast rules for every human relationship involved in the operation of officers' messes and officers' quarters. ${ }^{41}$

Thus at first, higher headquarters left Army installation commanders to operate under the assumption that black officers would have segregated facilities like the enlisted. But in practice facilities for black officers was an added level of complexity and the application varied from post to post depending on a number of local circumstances, the most critical being the number of black officers on post. At those few installations where large numbers of black officers were expected, installation commanders often requested funding for and built separate barracks for the officers.

More often than not, however, an installation would find itself with only a few black officers. A separate barracks built exclusively for black officers meant a big empty barracks, and in some cases, that is exactly what happened. On more than one occasion a black officer found himself assigned alone or with a few others to an otherwise empty barracks. Other installations

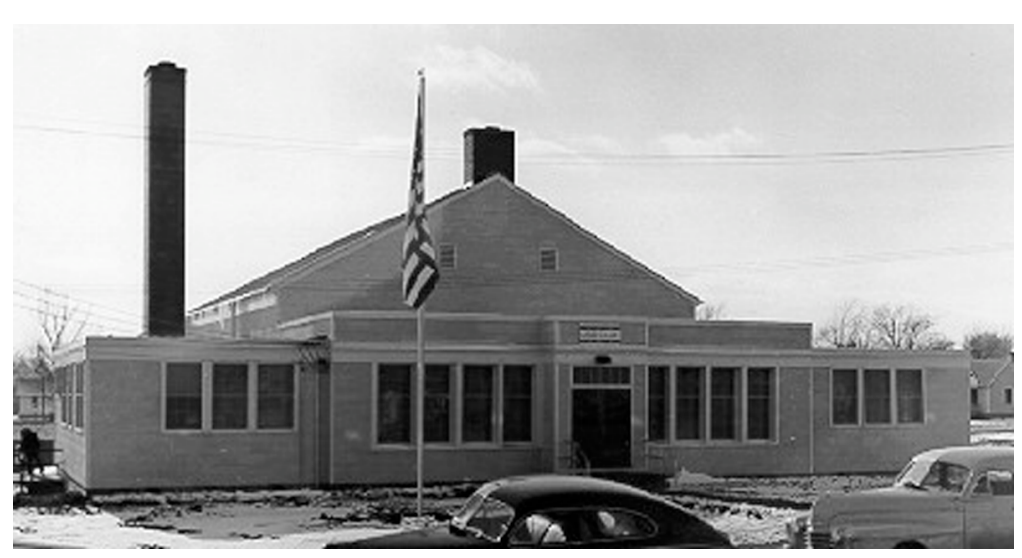

Figure 4.5 Black USO at Lebanon, Missouri (courtesy History Office, U.S. Army Engineer Center, Fort Leonard Wood, Missouri).

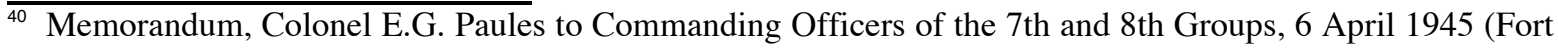
Leonard Wood, Missouri: History Office, U.S. Army Engineer Center).

${ }^{41}$ Memo to Judge Hastie, AG 15 September 1941, quoted in Lee, Employment, p. 223.
} 


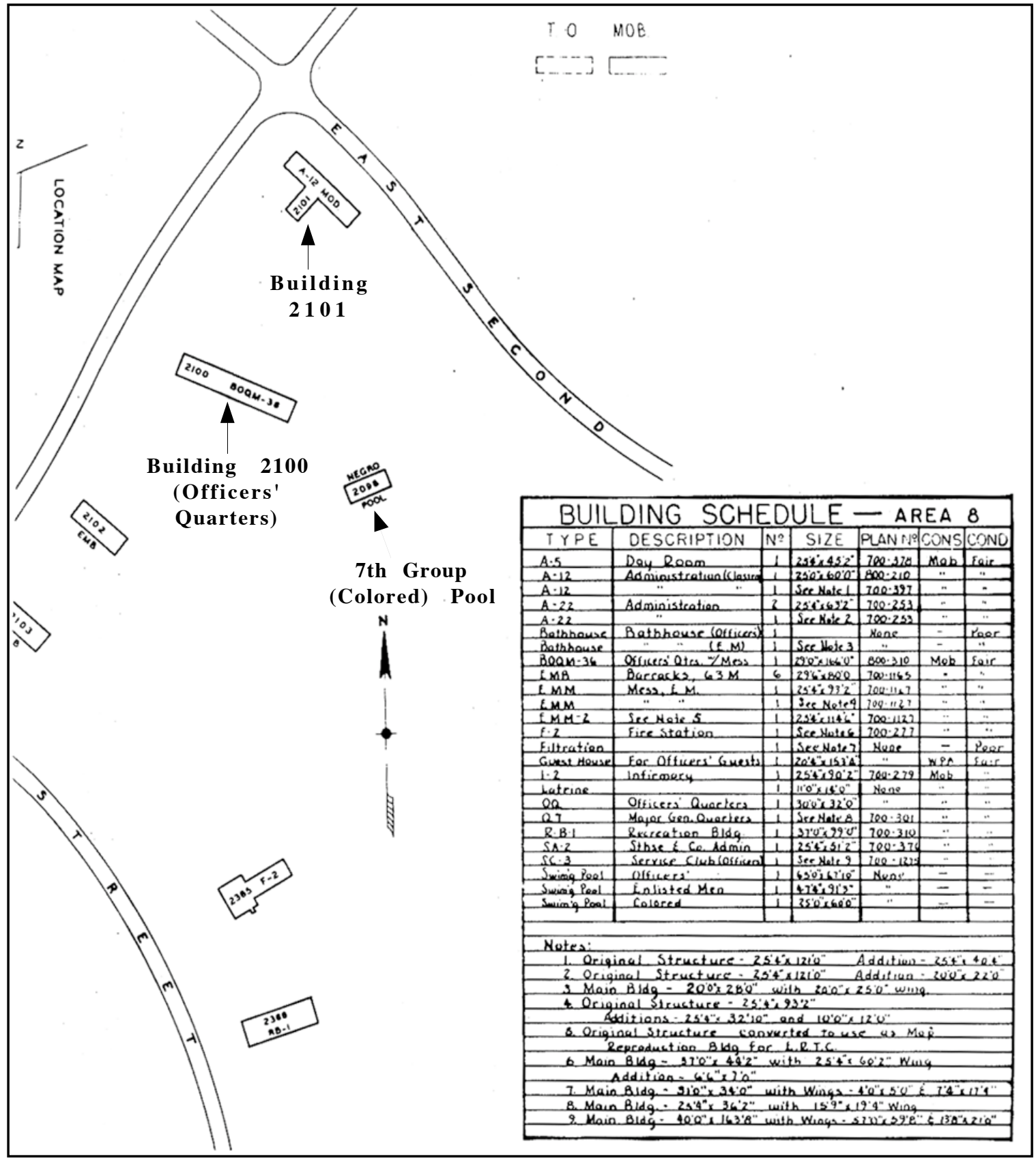

Figure 4.6 Fort Leonard Wood Master Plan, 1946 Showing a Portion of the 7th Group's Area (courtesy, History Office, U.S. Army Engineer Center, Fort Leonard Wood, Missouri).

solved this problem by assigning their black officers to off-post housing. Still others housed their few black officers with the non-commissioned officers or even enlisted men. ${ }^{42}$ In some rare cases, like the Special Service School at Washington and Lee University, black officers were housed with white officers. ${ }^{43}$ Fort Leonard Wood, with a relatively large officer contingent may have been another of those rare cases where white officers and black officers were housed together. The ${ }^{42}$ Lee, Employment, p. 221-224; Grant Reynolds, "What the Negro Soldier Thinks About this War," The Crisis Volume 51, No.9, 1944:289-291.

${ }^{43}$ McGuire, Taps, p. 39. 
exact housing arrangements for black officers is yet another mystery in keeping with the mysteries associated with the Black Officers' Club. The same anonymous informant that related the incident at the installation officers' club instigating the order to convert Building 2101 to a black officers' club also asserts that black officers had separate quarters across the street from the club. In fact, there was a barracks, probably built for black officers, located behind and across the ravine from Building 2101, between the club and the main headquarters buildings. This building was Building 2100 and is documented on a 1946 map of the post (Figure 4.6). On the map it is called a BOQ/M-36 or Bachelor's Officer Quarters, with mess. The "36" probably refers to the number of individuals that could be housed therein. According to this map, the building was 29 feet by 166 feet. The building is not documented in the installation landscape or final completion reports of April and June 1941. Thus it was not built in the initial construction phase. However, Building 2100 is mentioned once in the December 1941 phonebook as being the office of Captain Crawford of the 35th Battalion Headquarters and thus it is assumed that the building was being used as the Battalion Headquarters at that time and was built between June 1941 and December 1941, probably as a result of the ERTC's first expansion. ${ }^{44}$ A later telephone book dated January 1943, indicates that the building was being used as an officers' quarters by then and it has an asterisk after its number, which stood-for "Indicates Colored Troops." However, buildings 2107, 2108, and 2109 were also officers' quarters for the 7th Group and they also had an asterisk after their building number. There are two possible conclusions to draw from this: 1) the asterisk indicated 7th Group buildings regardless of their occupancy (i.e. it included white officers in the 7th Group), but building 2100 was still restricted to black officers; or 2) black officers were housed in all four barracks along with white officers. The latter is possible given that it is clear that black and white officers messed together. Further, if a 1944-45 researcher's card is correct, there were at one time over 84 black officers on post and Building 2100 could not have housed them all. At least for a while it seems, black and white officers could well have been housed in the same buildings.

Officers' messes were another unique problem, and again, black officers found themselves dealing with a wide variety of messing arrangements from an integrated mess with fellow officers, to being messed with enlisted men. ${ }^{45}$ At Fort Leonard Wood, as has been seen, white and black officers messed together, but traditionally sat at separate tables.

If policies regarding officers' quarters and mess were avoided, higher headquarters was even more loath to interfere with officers off-duty. Again, the establishment and running of officers' clubs was strongly held within the officer corps. Furthermore, the customs, written, and unwritten codes of conduct associated with the officer brotherhood and by association officers' clubs, were held sacrosanct by long-standing traditions going far back in time to at least the creation of professional and state armies in Europe. Officers' clubs were places where officers, regardless of rank, could meet and socialize in a semi-informal environment away from the parade ground or ${ }_{44}$ Fort Leonard Wood Phone Book, December 1941, (Fort Leonard Wood, Missouri: on file, History Office, U.S. Army Engineer Center).

${ }^{45}$ Ibid., p. 37. 
training area. There was a familiarity tolerated between officers within the walls of the officers' club which was not appropriate on duty. Officers' clubs were places where officers of equal rank could casually discuss problems associated with their commands. Senior officers could take aside a junior officer and make important suggested improvements without making an issue official. Likewise, junior officers could approach officers of higher rank with problems. Critically, this interaction forged a bond between officers of different rank and assisted not only morale but also in consistent unit leadership. Socializing in these clubs was actually fundamental and critical in building unit cohesion and morale, and was also critical to officer advancement. Historically, although the Army built officers' club buildings, the clubs had their own operating rules that had served well over time. Officers became members of officers' clubs by paying dues. Officers were expected to pay these club fees to stock the clubs with 'supplies' beyond those provided by the Army.

Officers' clubs, and all the important interaction that occurred in these buildings were almost universally denied the black officer in WWII. For while white officers worked side by side with black officers on duty, off-duty, few white officers wanted to socialize with black officers, and in some cases, vice versa. Black officers were routinely denied access to the officers' clubs across the country. "Efforts of commanders to intermingle their white and colored subordinates in officers' clubs were steadfastly resisted." ${ }^{46}$ Even at installations like Fort Huachuca, Arizona, where the 92nd Division had large numbers of both white and black officers working side by side, eating at the same mess, and living in the same barracks, white and black officers socialized in separate black and white officers' clubs. ${ }^{47}$ At posts where there were few black officers, which was usually the case, black officers simply had no club. There are even examples where black officers were expected to pay dues but not enter the white club. In one of the few published diaries written by a black officer of WWII, Lieutenant Colonel Jesse Johnson makes it repeatedly clear that black officers were not offered membership or allowed in the officers' clubs at the many posts to which he was transferred. In one instance, he was with several other black officers who, under the influence of too much alcohol, were discussing crashing the officers' club. An old veteran took them to task and reminded them of their status. As Johnson concluded "Two brass bars won't get you into the post's one white club."148

\section{The Establishment of a Black Officers' Club}

Black officers at Fort Leonard Wood during WWII had their own officers' club, Building 2101, which still stands in the same location as it did at that time and today is used as the installation's environmental office (Figure 4.7, 4.8, 4.9). As stated in Chapter I, the circumstances surrounding its designation as a Black Officers' Club were unknown, and this was a key question to be answered by this research. Another specific question was to learn more about a mural painted

${ }_{46}$ Wiley, The Training of Negro Troops, p. 30.

${ }^{47}$ Ibid., p. 224.

${ }^{48}$ Johnson, Ebony Brass, p. 49. 
above the

fireplace in the

building, its

artist, and the

context in which

it was painted.

The following

section focuses on

what is known

and speculated

concerning

Building 2101 and

its use history.

Chapter V

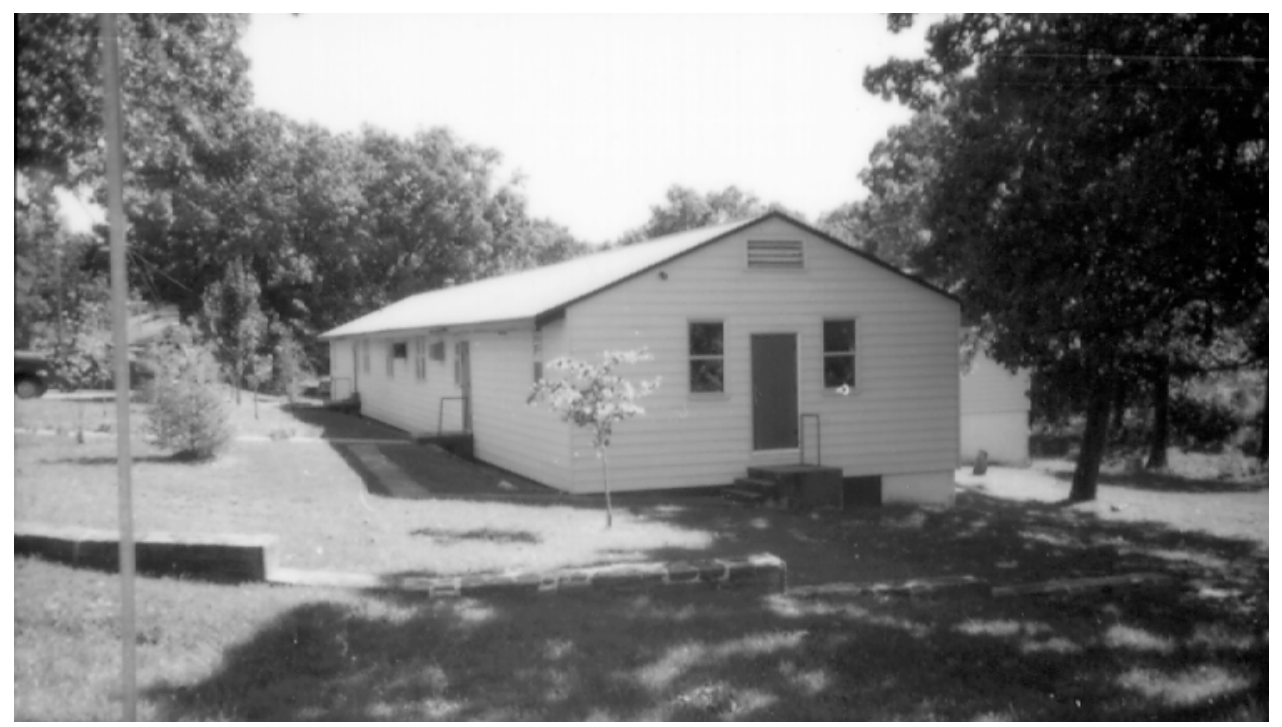

discusses the

mural and its artist.

Informant testimony noted in the first chapter asserts that Building 2101 was built after an incident at the installation's officers' club in which black officers were denied access during a social function. According to the story--told to Fort Leonard Wood's museum curator by an informant whose identity is now forgotten--shortly after this incident General U.S. Grant ordered the construction of a separate club. Previous researchers had uncovered the fact that the building was actually constructed during the post's initial construction and was first used as a Personnel Adjutant's Office for the 7th Training Group. Building construction was completed by June 21, 1941 according to the completion report for Fort Leonard Wood, probably by March 24th. ${ }^{49}$ Thus, it is known that the building was not specially constructed for black officers, but that sometime after the opening of the ERTC it was redesignated and used as a club for black officers. Unfortunately, despite an intense survey of several archives and review of military records, the exact details concerning the building's conversion to the black officers' club still have not been discovered, and the validity of the incident related by the oral history has neither been verified nor determined false.

Extant post telephone books still provide the best direct evidence for bracketing the period within which the 7th Group's personnel office was converted to the Black Officers' Club. The post's first phone book is dated February 1941, when the post was still being built. The second dates to December 1941, and lists exchanges by building numbers. Building 2101 is noted as the Personnel Adjutant's Office for the 7th Group in the December telephone book. The next pertinent extant

\footnotetext{
${ }^{49}$ Every existing building at Fort Leonard Wood has a Property Record Card on file at the Real Property
} Division of the Directorate of Public Works. The card for 2101 indicates that the building was completed on March 24, 1941. In keeping with the building's steadfast reluctance to reveal its secrets, there is no date on the card indicating when the addition was added. 


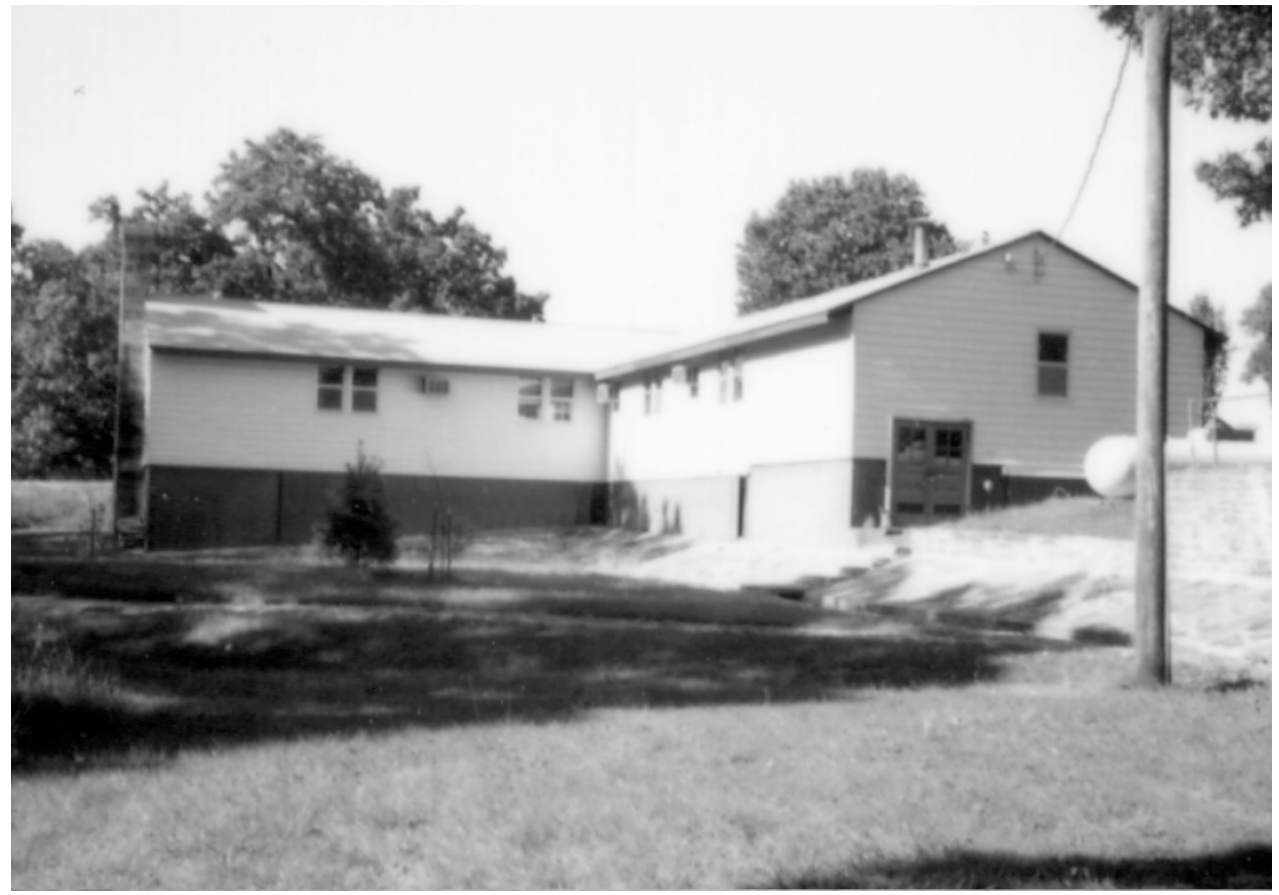

Figure 4.8 Building 2101 From Ravine (SCIAA). telephone book is dated January 1943 , and is the first indication that the building was then the Black Officers' Club. It is listed twice. First it is listed on page 19 as the "Officers' Club Annex." It is again listed on page 35 as ERTC Officers' Club, this time with an asterisk $\left(^{*}\right)$ after the designation,

which was the manner in which the phone book indicated buildings used by blacks. ${ }^{50}$ As stated previously, the Army changed its facilities policy so that no clubs could be designated as for blacks or whites. The title "annex" was one way to get around this policy. The phone book evidence thus places the conversion sometime between December 1941, and January 1943, or basically, sometime in 1942.

At this point, narrowing down the time and the validity of the oral history becomes problematic and one can only turn to circumstantial evidence to build various arguments. First it must be stated that the incident in which black officers were denied access to the installation's officers' club and shortly afterward, General Grant ordered the creation of a black club, could have happened as told. Incidents of racial tension are evident at Fort Leonard Wood and include examples of tension between white and black officers, like the incident in the officers' mess. Furthermore, black officers were routinely denied access to officers' clubs at installations across the country, and incidents where black officers attempted to "crash" these clubs also occurred, as evidenced by Colonel Johnson's experiences. The oral history would be in keeping with the times, but at the same time, the fact that it happened elsewhere also raises the possibility that the oral testimony here is apocryphal, that is, it was something that happened at other installations and was transferred by the informant as having happened at Fort Leonard Wood.

\footnotetext{
${ }_{50}$ Fort Leonard Wood Telephone Books, February 1941, December 1941, January 1943, July 1944 (Fort Leonard Wood, Missouri: History Office, U.S. Army Engineer Center). As mentioned, the asterisk in the January 1943 book stood for black personnel, specifically: "Indicates 7th Group." A later, 1944, telephone book is more emphatic stating "restricted for the exclusive use of Negro personnel."
} 


\begin{abstract}
Another
valid argument is that the incident happened but within a different context. In this case, black officers had no club and, given the racial environment at the installation, General Grant ordered a club created-- but not as a result of a direct confrontation
\end{abstract}

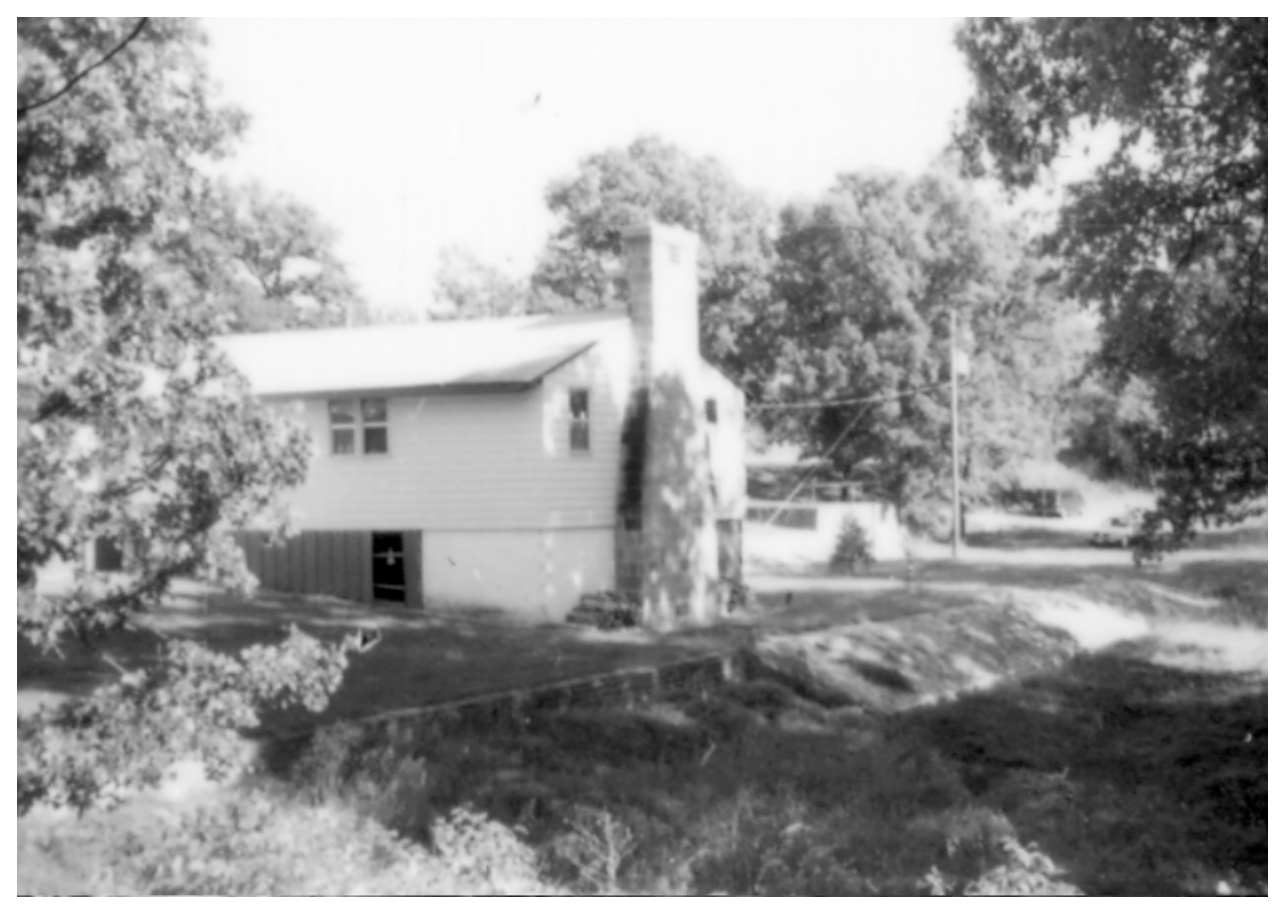

Figure 4.9 Building 2101, Rear From Street (SCIAA).

involving black officers at the main club. This argument is supported, again circumstantially, by documents indicating that Grant had an intense concern about providing recreational facilities for his men, and was also keenly aware of potential racial problems. It was he that proactively attempted to avoid racial incidents by keeping the men busy at training and by providing adequate recreational activities as early as possible. It would be in keeping with these records that he ordered the club to improve morale, and to avoid racial incidents between officers like those seen later in the war. But neither scenario fully satisfies when one considers other circumstantial evidence, as is described below.

With the above in mind, it is possible to narrow the time frame for the conversion even further to a period between June and December 1942. Why is a post June 1942 date likely? Because the letter to the NAACP by Lieutenant Jones's attorney related in Chapter III indicates that Jones was one of the first two black engineer officers to be commissioned during the war and was probably the first or one of the first to arrive at Fort Leonard Wood in May 1942. There is much supporting evidence that this is correct. Although the engineer Officer Candidate School at Fort Belvoir opened in July 1941, and Fort Leonard Wood's Officer Training School opened in January 1942, it appears that no blacks were in either school until after Pearl Harbor or, until 1942. Between July and mid-September 1941, there were only 17 blacks in Army Officer Candidate Schools, only six more in December, and according to Lee, none were in the Engineers. ${ }^{51}$ The earliest that black engineer officers could have been at Fort Leonard Wood was in early 1942 and May seems to be the

${ }^{51}$ Lee, Employment, p. 202. 
most reasonable date for their earliest arrival. ${ }^{52}$ Thus it is very likely then that Jones was one of the first commissioned black officers at Fort Leonard Wood, perhaps the first, arriving in late May 1942 and remaining there until mid-August. ${ }^{53}$ During the time that Jones was stationed at Fort Leonard Wood there were at least 14 other black officers assigned to Fort Leonard Wood, for he and the 14 were sent to Fort Huachuca after August. In any case, the creation of a Black Officers' Club most likely would not have even been an issue until Lieutenant Jones and his fellow black officers' arrived on May 20, 1942. Technically then, Grant probably didn't order the building's conversion, or if he did, it had to have been one of the very last orders he gave before his transfer on June 27th, 1942. More likely, his successor, Colonel Besson ordered the conversion of the personnel office, or possibly, Besson was carrying out Grant's order. When General Garlington assumed command on January 20, 1943, the telephone book printed at that time indicated that the building was already the Black Officers' Club. One must add as an interesting aside, that Grant wrote a friend in September 30, 1942, about what was happening at the Fort after he left. He notes that "The swimming pools are completed and working, as well as the additions to the Officers' club." ${ }^{154}$ Also, in his interview in 1945, he mentions that the building of service clubs were left until long after the fort's construction was complete. Both of these circumstantial pieces of evidence support a post June 1942 date.

This timing--the late summer or fall of 1942--proposed above, means that it is also possible that the conversion of Building 2101 was the result of General Benjamin Davis' special inspection of black troops in June 1942, shortly before Grant left. General Davis did not mention the lack of a Black Officers' Club in his report, but in reaction to his recommendations for an expanded guest house a June 30,1942, letter stated that in addition to looking into the guest house expansion, the G7 of the Seventh Corps Area had advised the War Department that a study was being made of recreational facilities for colored troops and, if required, additional construction would be requested. The study results were not discovered during this research but it is possible that the Black Officers' Club was part of an expansion of black facilities initiated by Davis' inspection.

A critical fact in this research is the realization that since the building was not built especially as a Black Officers' Club, but rather converted from a personnel adjutant's office, a written order to build an officers' club would not have been issued. Moreover the use of the words "Black Officers' Club" would not be found on any official Army documentation. More likely an order would have been issued for modifications to the adjutant's office making it usable as an officers' annex. In 1943, the Army officially forbid the designation of recreational facilities as negro or white. In January of that year Fort Leonard Wood already was designating buildings ${ }_{52}$ Oral testimony by retired Master Sergeant Delanious Gossett, who was at Fort Leonard Wood from May 1941 to January 1942 further supports this as he remembers no black officers during that period, Interview by the author of Sergeant Gossett, October, 16, 1997.

${ }^{53}$ Also note that in December of 1941, the black officers' barracks was being used as an office, further supporting the fact that black officers were not on post at that time.

${ }^{54}$ Letter, U.S. Grant III to Lt. Colonel John R. Baird, 10 September 1942, MS344, Grant Papers, Historical Society of Washington D.C. 
reserved for blacks by the use of the term "annex" in the case of the Officers' Club, or for exclusive use by the 7th Training Group (black) in the case of enlisted housing and recreation. It has been seen that black officers ate at separate tables at the officers' mess. As a result of the incident where a black officer sat next to a white officer, a battalion commander's first reaction was to verbally order a separation between whites and black in the mess. This incident provides some evidence that racial incidents were often solved verbally where possible. Therefore, it is possible that with the arrival of black officers at the post in the spring of 1942, long after construction was completed at the post, and either as a result of a particular incident or to avoid an incident, a separate building was provided for black officers and they were simply told where they could socialize.

Given the facts and circumstantial evidence presented above, the author proposes the following scenario regarding the creation of a Black Officers' Club at Fort Leonard Wood. It is proposed that Building 2101's conversion to a black officers' club was the result of General Grant's desire to concentrate all administrative functions in a centralized headquarters, a desire that was not fullfilled until after he left, but which was carried to completion by interim ERTC commander Colonel Besson. The ERTC underwent a major reorganization in September 1942. As part of this reorganization, the organizational chart indicates that administrative and headquarters functions were centralized. Before he left, Grant complained that administrative functions were too spread apart, and requested additional construction necessary for the forced expansion. It is likely he got it. This reorganization would have been a prime opportunity to move Personnel into a centralized facility leaving Building 2101 open for the black officers, Building 2100 as their barracks, and incidentally Building 2102, another A-12 administrative building just down the street, open for use as a Black Non-commissioned Officers' Club. Racial incidents, General Davis's visit, and the increased number of black officers on post through that fall all contributed to increase the need for a club and the reorganization provided a perfect opportunity. Although, admittedly, this argument cannot be verified any better than the oral testimony that General Grant or Colonel Besson ordered the club as a direct and immediate result of black officers attempting to enter the installation officers' club, it is a reasonable and highly plausible scenario fitting the time frames involved, the factual evidence, the circumstantial evidence, and the social attitudes prevalent.

Since it is highly probable that Building 2101 became the Black Officers' Club sometime after June 1942, and quite possibly in September, it is also likely that the building was simply turned over to them at first without much modification. Whatever was done was minor. One can guess that the desks were moved out, and pool tables and chairs were added. It was not until almost a year later that the major modifications, the wing addition seen today, were initiated. While the order for these modifications was not found, the April 2, 1943 issue of the Fort Wood News, has the following article under the headline "Enlarge 7th Group Club:"

A large recreation hall, four new guest rooms, and a new floor are being constructed in the 7th Group Officers' Club annex. The 
remodeling is expected to be finished within 10 days according to the manager.

This newspaper article is the only documentary evidence that the officers' club annex (i.e., Building 2101 now being used as the Black Officers' Club) was enlarged. It probably was enlarged to accommodate the growing number of black officers at the installation, for in August of that year, Fort Leonard Wood complained that it had far too many black officers and recommended that 84 be transferred. ${ }^{55}$

What went on within the walls of this club can only be speculated upon. It is easy to imagine that black officers assigned to the ERTC and those awaiting assignment elsewhere were able to gather, socialize, relax, and most assuredly shared stories of their latest experiences in this segregated Army. One can almost see them gathered around the fireplace, sitting, talking and laughing, all under a mural depicting a quiet day in the country (see below). Most assuredly the place was barely furnished, perhaps some well-used lounge chairs around the fireplace, but mostly furnished with functional wooden chairs and desks. There were probably a few books and magazines, a radio, and likely a number of well-read back issues of the Chicago Defender or the Pittsburgh Courier, black newspapers avidly read by black soldiers during the war. Some recreational facilities on post had a piano; perhaps this club did also. In the center of the rooms there were probably pool tables, and perhaps in storage there was a moving picture screen and projector. ${ }^{56}$ Located in the heart of the ERTC training area, the building was not exactly a 'get away from it all' site. But it must have been a convenient and welcome oasis from their duties, or lack of duties, on post. It was also conveniently close to their barracks--convenient for both the officers and for control by the ERTC/ ASFTC command.

Being excluded by protocol from black enlisted men and noncommissioned officers, and by segregation from white officers, the black officers must have forged a tight brotherhood. The Black Officers' Club was where that bonding occurred. Evidence of this brotherhood is seen in the historic record. At Fort Leonard Wood, black officers banded together to seat themselves around the officers mess over a period of a few days. An almost identical incident happened at Fort Huachuca, except in this case, white officers ignored the provocation and the black officers went back to their traditional area. As noted, incidents of black officers being refused entrance to installation officers' clubs are numerous. ${ }^{57}$ Being shifted from one installation to another sometimes in groups, and being among a select few of engineer black officers, these men probably met more than once, and word of racial injustice at one post was known quickly at others. Building bonds and ${ }^{55}$ Again, this number seems far too large. The actual memo does not exist. There is only a reference to the memo written on one of the "Cards," by the ASF historian.

${ }^{56}$ A request for surplus equipment shortly before the fort was deactivated indicates that there were considerable numbers of abandoned moving picture screens and projectors, soda fountains, and such in the recreation and service club buildings available for the National Guard. Brigadier John A. Harris, Adjutant General, Missouri National Guard to The Chief, National Guard Bureau, Washington, 20 March 1946, RG 160 RG 160, Army Service Forces, (College Park, Maryland: National Archives).

${ }^{57}$ Wiley, The Training of Negro Troops, p. 31 . 


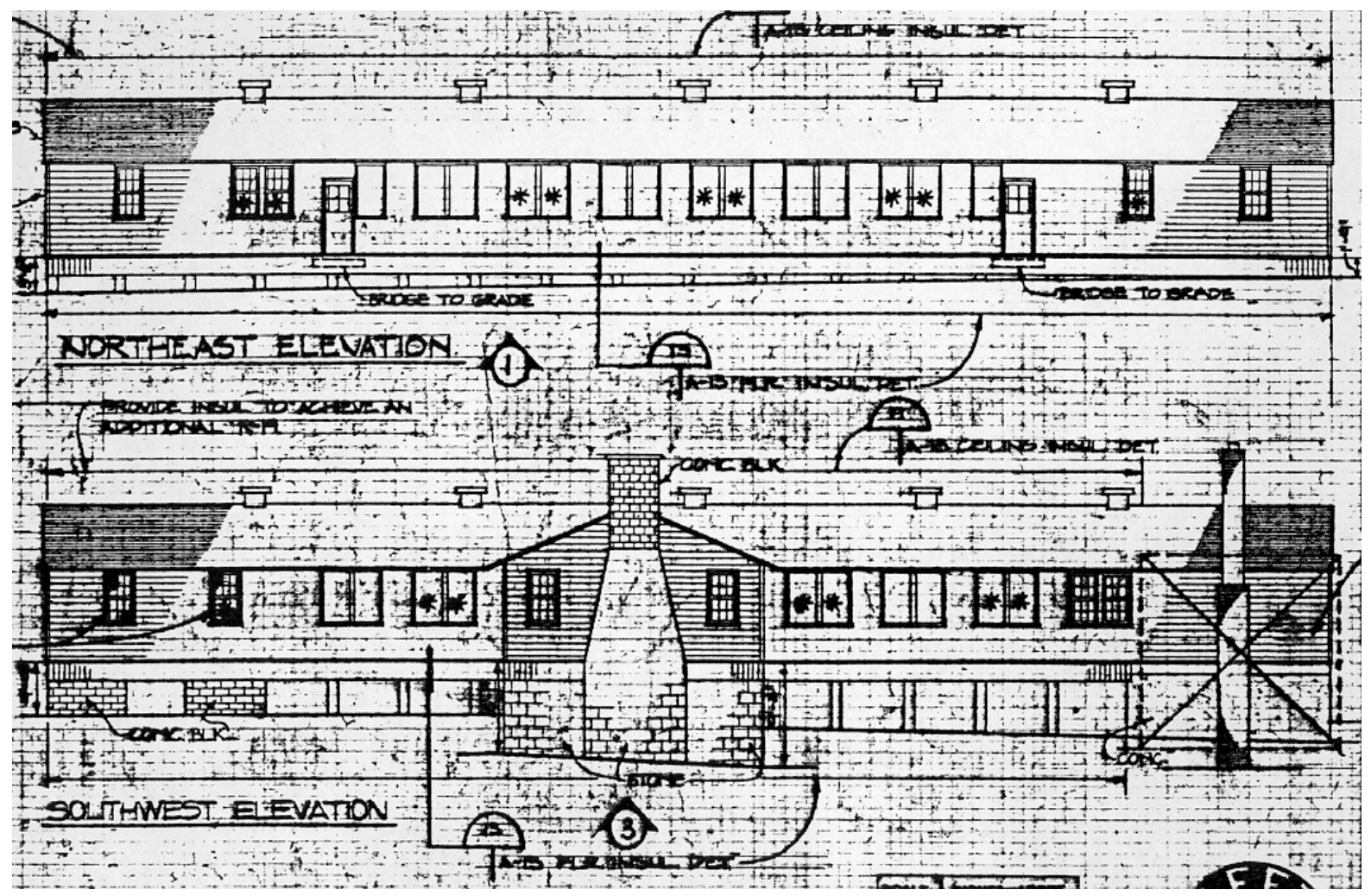

Figure 4.10 Building 2101, Elevation Front and Back (1979).

friendships, sharing the strain of being in an often unfriendly environment, letting off steam from the day's events, and talking of better times to come, the Black Officers' Club served a critical function for maintaining black officer morale at Fort Leonard Wood.

\section{Building 2101}

Prior to the expansion, the Black Officers' Club was a standard, unmodified A-12 administration building (Figures 4.10, 4.11). These long rectangular buildings contained 2,740 square feet of floor space, and were 25 feet, 4 inches wide by 108 feet, 2 inches long. The basic interior design was a large open bay, with two small offices on one end and a heating room and two lavatories on the other. This plan was standard for all administrative buildings A4 through at least A17, the difference between each being the building length or more specifically its central bay length. Set up on concrete piers, they were primarily wood stud construction, gypsum sheathing, and rarely, if ever, insulated. A-12 administrative buildings were to be used as offices and classrooms, although the center posts were inconvenient for large classroom demonstrations. Twelve of these buildings were built on the post during the war, at a cost of $\$ 11,296$ each..$^{58}$

\footnotetext{
58 "Individual Building Reports For Historical Record," 30 September 1945, and "Project Cost SummaryMilitary Funds, Final Detail Cost Statement," (Fort Leonard Wood, Missouri: History Office, U.S. Army Engineer Center).
} 
As described in the newspaper article quoted above, guest rooms and a floor were added during the 1943 expansion. These alterations consisted of adding a wing perpendicular to the main building's length and joining the building at the center of the rear (southwest) wall, making a "T." Where this wing projected away from the club building, the ground falls away sharply into the ravine that separated the main black ERTC housing facilities from the headquarters buildings. This created a space for another floor below the wing's main floor, as noted in the newspaper article. Today, this space is not a separate room but a crawl-space, however, there is a second fireplace hearth in this crawl-space and so there is at least evidence that there were plans for an additional floor as stated in the newspaper account. The wing's upper floor is 25 feet by 39 feet, 6 inches, providing an additional 990 square feet of floor space. With possibly as many as 84 "extra" black officers at Fort Leonard Wood, this facility would have been crowded during 1943, and the additional wing would not have have been enough for large social gatherings. More likely, the building was used primarily as a day room, and the black officers went off-post for dances.

Today, one of the building's exterior attractions is its beautifully crafted stonework landscaping that provides erosion control, sidewalks, and a stone chimney on the addition's gable. This stonework is the handiwork of German WWII Prisoners of War (POWs). Stone construction at the installation consisted of roads, walkways, walls, levees, and landscaping around buildings like the Black Officers' Club (see Appendix). ${ }^{59}$ The craftsmanship of this stonework is exceptional and indicates a great deal of care was taken in its design and construction. The exterior chimney, which supports a stone fireplace on the main floor, is constructed of coursed squared stonework. A date, "1945," with a bas-relief eagle is seen about 10 feet from the ground. Walkways and drainage ditches around the Black Officers' Club are mosaic in style. The stonework gives the officers' club an ambiance of permanence not normally associated with WWII temporary structures. Furthermore, most of the stonework done by Fort Leonard Wood's POWs consists of ditches, cemetery walls and elaborate drainage culverts. There are only two other places on post where complex stonework edifices are found besides the Black Officers' Club. One is the Garlington House which boasts a chimney, patio, and barbecue pit. The other is a stone amphitheater. It is therefore curious and out of character with much of the known history of the ERTC that so much effort was devoted to the stonework at Building 2101, a building that could not even be officially proclaimed what it was, a segregated recreational facility.

\section{Post-War Use of Building 2101}

The survival of the mural and Building 2101 is a wonder in itself. The installation was shut down in March, 1946, and the base was placed on inactive status. Only a few caretakers were left on base. When the installation was deactivated there is evidence that large quantities of furniture and equipment were abandoned and requests for their requisition by the National Guard were forthcoming. From 1946 the only military activities at the post were the summer field

\footnotetext{
59 Harland Bartholomew \& Associates, Cantonment Survey, pp. 7-13.
} 


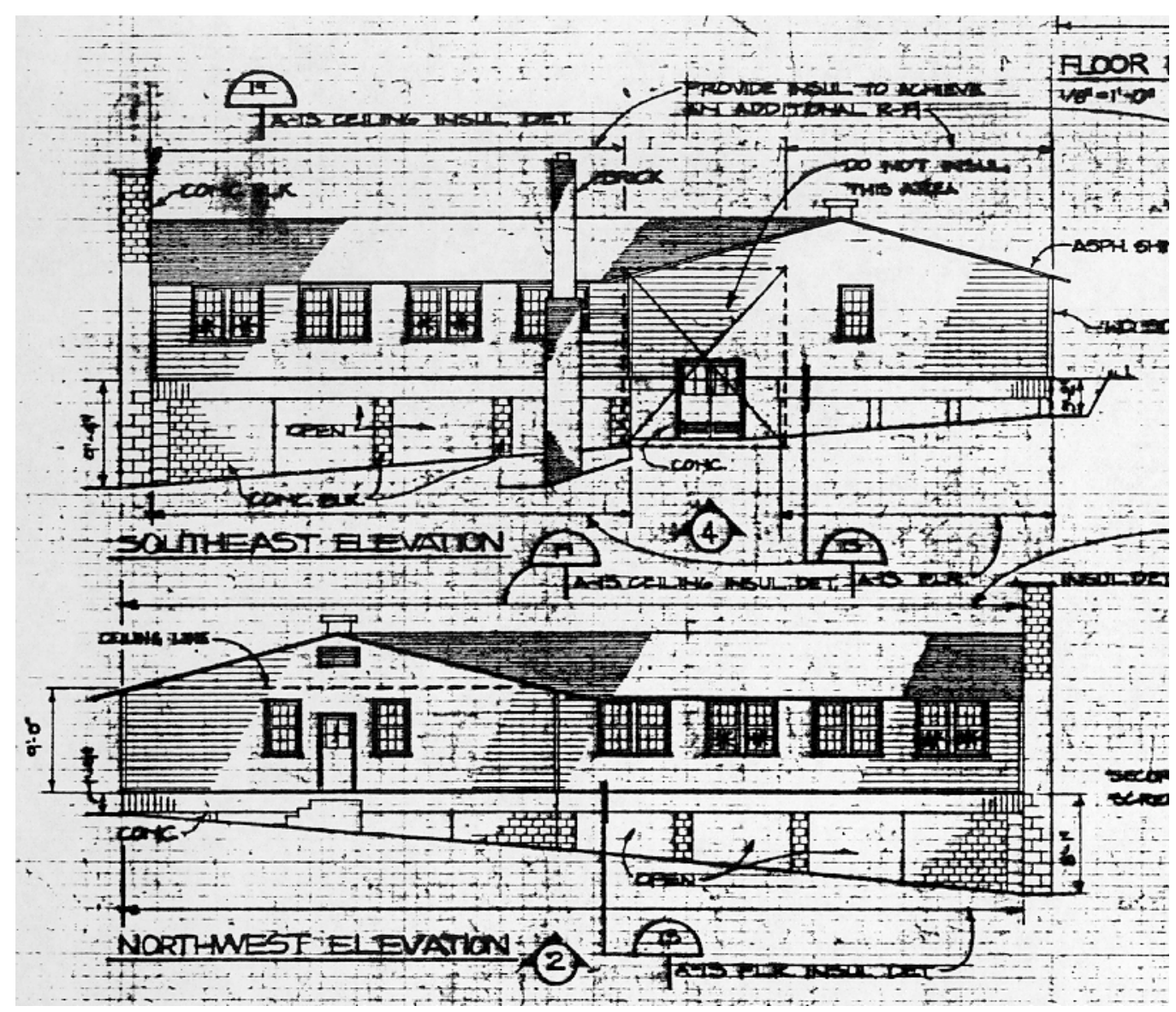

Figure 4.11 Building 2101, Elevation Addition (1979).

training exercises by the National Guard. In 1947, 88 buildings were placed in surplus. But on August 1, 1950, the base was back in operation as a result of the Korean conflict.

A Congressional investigation of military preparedness in the Armed Services included a visit to Fort Leonard Wood in March, 1951. The fort's greatest shortcoming according to this investigation was housing for dependents. Nearby Waynesville was still only populated by around 1,000 people and there simply was no place for soldiers' wives and children to live. The report also mentions the condition of housing and facilities. Although the barracks were considered adequate, the hot-air furnaces, like the one at the Building 2101, were fueled by soft Missouri coal and spewed-forth large flakes of soot over entire housing areas. The installation was considering using natural gas for heating to alleviate the choked environment. The inspectors also noted that the installation's buildings badly needed painting. The installation requested that 45 day rooms and an entire new company area be constructed. Recreational facilities were considered limited but adequate, again stymied by the post's isolation from large civilian communities. ${ }^{60}$ Overall, it would seem from this report that the buildings on post were in poor repair, the result of years of

$\overline{{ }^{6}}$ Fort Leonard Wood, Missouri, Investigation of the Preparedness Program, Twelfth Report, S. Res. 18, 82nd Congress, Document No. 83 (Washington D.C.: US Government Printing Office, 1951). 
neglect after 1946, and that when the army reopened the base it had had little time for making improvements.

The conditions described above are confirmed by the oral testimony of Mr. Robert Howard. Howard was with the 6th Armored Division and worked in Building 2101 during the early 1950s. At that time, the building was in such poor condition that there were holes in the roof through which "you could see all you wanted to see." He recalled that the building was used as a processing and reception center from around 1954 to 1957. This is in keeping with a 1956 phone book indicating that the building was, again, a Personnel and Reception station. From 1960 until 1981 the building was the home of Fort Leonard Wood's Rod and Gun Club. From 1983 until 1989 it was a coffee house connected with the chaplain's service. Today the building houses the offices of the Environmental and Natural Resources Branch of the Directorate of Public Works, a use which began in $1990 .^{61}$

Between 1957 and the present, plans in Fort Leonard Wood's Directorate of Public Works indicate that the building underwent improvements around every ten years. The plans date December 4, 1963, July 1979, April 25, 1985, May 1, 1989, and April 17, 1997, and all depict various modernizations like room arrangements, furnace replacement, installation of storm windows, and communications wiring. Today, the building has aluminum siding and additional doors, added around 1981. However, the basic framework and physical context of the building as it was in 1945 still survives. Amazingly, through 50-odd years of building use and in some cases neglect, the mural has survived.

\section{Summary}

Building 2101, a converted standard A-12 WWII temporary building was designated as an officers' club for black officers stationed at Fort Leonard Wood, sometime between June 1942, and January 1943, quite possibly around September 1942. The building was provided either as the result of a provocation by black officers to assert their right to enter the installation's officers' club, or because ERTC authorities recognized that there would be a need for the newly arrived black engineer officers to have their own separate facility to maintain racial harmony. The following summer, the building was expanded to provide additional space for the growing corps of black officers on post. Care was taken to enhance the exterior and interior of the club by the opportunistic use of POW skills around the exterior and the skills of a talented artist to paint a mural above the addition's fireplace. All of these enhancements add to the significance and charm of Fort Leonard Wood's unique Black Officers' Club.

\footnotetext{
${ }_{61}$ Post 1957 use history is from Kermath, et al. 1996, Historic Restoration.
} 


\section{CHAPTER V: SAMUEL COUNTEE AND THE MURAL IN BUILDING 2101}

\section{The Mural}

The exterior POW

stonework around Building 2101 set it apart from the surrounding standard WWII temporary buildings both then and now. But what binds this building to its unique and intriguing past as a club for black officers is the mural

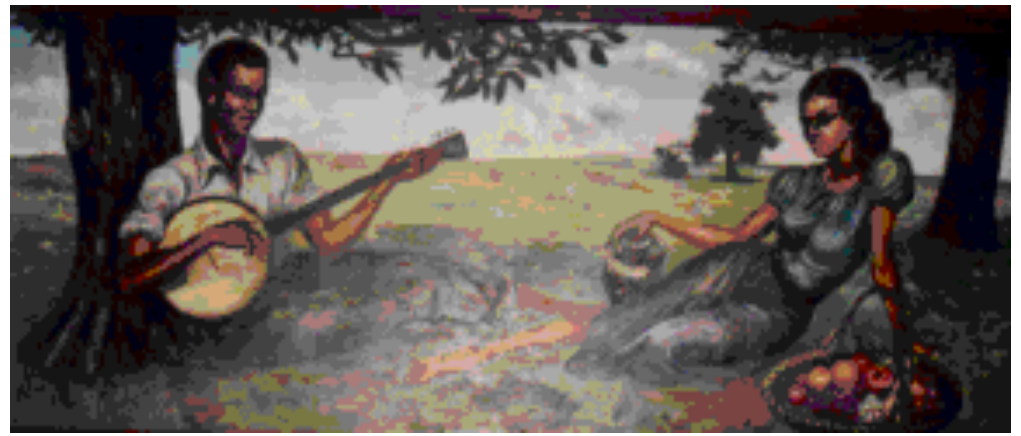

Figure 5.1 The Mural At The Black Officers' Club (SCIAA). hanging above the fireplace at the gable in the building's addition. This four by 10.5 foot mural depicts a black couple at a picnic, he playing a banjo and she lounging back on one arm, listening (Figures 5.1 and 5.2). A professional conservator restored the painting in 1995. ${ }^{1}$ His report notes that the mural is painted on three plywood panels. The plywood is mounted on furring strips and they are anchored to the wall, probably with nails, but that is not absolutely clear. The mural's frame is attached by both nails and glue. The center panel is 48 inches wide, the two side panels are 39 inches wide and all are approximately $3 / 8$ inch thick. The painting is done in oils, with a white ground layer. Both the oil and ground layers were applied unevenly.

The painting is signed; however, the signature is not entirely readable despite recent cleaning and conservation. Years of people attempting to clean the signature in order to read the artist's name have in fact rubbed most of the signature away. It is clear that the signature begins as "S/Sgt" or Staff Sergeant. The first name includes the letters "M" and "L," and the letters "S" and "A" are vaguely visible, but the rest are unreadable. The beginning letters of the last name are also illegible, however, the final four letters in the last name appear clearly as "N-T-E-E." The lettering is clean, blocky and distinctive, with the final letters of the last name appearing to gradually enlarge from left to right. Through a fortunate series of circumstances the author has been able to identify the artist as being Samuel Albert Countee, an aspiring young black artist at the time the mural was painted. Countee not only signed his name but also dated the mural. Again,

\footnotetext{
Strictly speaking, this work of art is not a mural, but a painting. By definition, a mural is a work of art painted or applied directly to a wall and cannot be detached without destroying the art and the wall. However, the conservator who restored the mural refers to it as both a painting and a mural, traditionally it has been called a mural, and the author sees no reason to change. The conservator's use of the word mural probably refers to the fact that it was painted on separate plywood panels, which appear to be attached permanently to the wall with nails. Removing the mural would most assuredly destroy the painting and thus it is tied to the wall--for that reason it can be called a mural. See Don Kermath, Amy J. Lamb, Tracy Hewitt, Doug Hicks, Rick Strilky and Robert Score, Historic Restoration of the Black Officers' Club at Fort Leonard Wood, Missouri (Champaign, Illinois: on file, USACERL, draft manuscript, 1996).
} 
the date is obscure, but appears to be either 1945 or 1943. Given what is known about Samuel Countee's life, either date is possible.

\section{The Life of Samuel Countee ${ }^{2}$}

That Samuel Countee is the mural's artist is also assured. At this point documentary evidence of his life at Fort Leonard Wood is almost nonexistent. But what facts can be

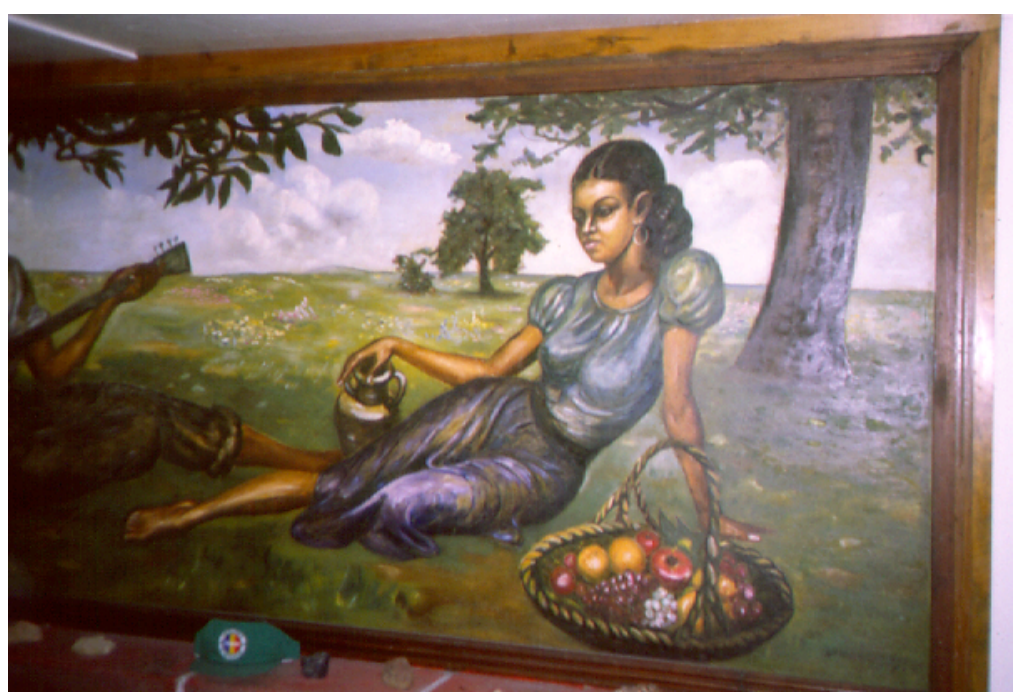

Figure 5.2 Close-up of Mural, Building 2101 (SCIAA). documented, combined with informant testimony by close associates and relatives, is conclusive evidence that Countee painted the mural. The following is what has been learned about the life of Samuel Countee to date.

Samuel Albert Countee was born on April 1, 1909 in Marshall, Texas. Very little is known about his childhood, but it is known that he and a sister were born in Marshall while his mother, Nannie S. Countee, was Matron of Women at Bishop College, which was located at that time in Marshall. ${ }^{3}$ She and her husband, Thomas Countee, eventually had five children, one of whom died in infancy. The family soon moved to Houston, Texas, where Samuel was raised. He attended Gregory Elementary School and Booker T. Washington High School in Houston.

As a young man, Samuel returned to Marshall, Texas, in 1929 to attend Bishop College, receiving an A.B in 1934. ${ }^{4}$ He most likely was attracted to art and showed much promise long before starting college, for he was given the title of "Artist in Residence" while at Bishop, and received a Harmon Foundation scholarship in 1933. He presented works in exhibitions in 1933, 1934, and 1935. He clearly was a very talented young artist and was being watched by the black art world. His painting entitled Little Brown Boy, which had been exhibited by the Harmon Foundation in 1933, was described as "distinctly deserving" of its representation in the Harmon

\footnotetext{
2 The discovery and confirmation that Samuel Countee was the mural artist came as a result of an extensive and continuing archival, library, internet, and museum search being conducted by phone and e-mail. Most importantly, the author was able to find several of Mr. Countee's living relatives and friends who have and are continuing to generously provide biographical information and other assistance. This biography only scratches the surface of the intriguing life of Samuel Countee--a life worthy of much further study and discovery.

${ }^{3}$ Bishop College moved to Dallas in 1961 but closed in 1991. Today many of the buildings in Dallas are occupied by the Museum of African American Life and Culture.

${ }^{4}$ Theresa Dickason Cederholm, editor, Afro-American Artists (Boston: Trustees of The Boston Public Library, 1973), pp. 62-63; Lynn Moody Igoe, 250 Years of Afro-American Art: An Annotated Bibliography (New York, R.R. Bowker Company, 1981), pp. 582-583.
} 
Foundation art exhibition. ${ }^{5}$ Three years later, his painting entitled My Guitar was the "popular choice" when exhibited in the Hall of Negro Life at the Texas Centennial Central Exposition in Dallas. ${ }^{6} \quad$ The following year, in a 1937 book entitled The Negro Genius, Countee is picked for special mention from among "scores of young Negro painters" by the book's author, Alain Locke. Notes Locke: "One of the men who will bear watching is Samuel Albert Countee, who has recently made his way from Texas to study in Boston but who has already taken part in several exhibits." Clearly by the late 1930s, Countee's art career and reputation was growing.

By that time Countee had made his way to Boston, receiving a scholarship to the Boston Museum School in October 1934. ${ }^{8}$ Samuel did not take classes right away, but received a scholarship as an "Artist in Residence" serving as a "student assistant to aspiring young artists." During the period from 1934 to 1939 he only attended one course, that being Anatomy. However, beginning in 1939 he took courses and continued his study at the museum school until drafted into the Army in 1942. During the late 1930s he received As and Bs in Drawing and Painting, along with a course in Fresco Painting. However, other records indicate that he also studied at Harvard University from 1940-41. ${ }^{10}$ In any case, he continued to actively show his art in exhibitions at Howard University (1937), American Negro Exposition (1940), Atlanta University (1940), , Smith College (1943) and at the Institute of Modern Art, Boston. ${ }^{11}$ He also won prizes for his work, \$5.00 for a fresco in 1939 and $\$ 10.00$ for a painting in 1940 at the Museum School. Countee lived in an apartment while in Boston, but kept his home address as Houston.

Like millions of other Americans, the war changed whatever plans and hopes he had at the beginning of the 1940s. On May 2, 1942 he was "called for service," and entered the U.S. Army on May 12. ${ }^{12}$ For the next three years, Countee was in the Army and sometime after his draft date he was shipped to Fort Leonard Wood where he was with the 7th Training Group. ${ }^{13}$ Almost nothing is known about his life at Fort Leonard Wood, except that the mural indicates that he was a Staff Sergeant. If he was drafted into the Engineers directly from Boston, then it is probable that he arrived at Fort Leonard Wood as a basic trainee and earned his rank while at Fort Leonard

${ }_{5}$ Rose Henderson, "Negro Artists In The Fifth Harmon Exhibition," The Southern Workman Volume LXII, No. 4 (1933): 181.

6 Alonzon J. Aden, "Educational Tour Through The Hall of Negro Life," The Southern Workman, Vol. LXV, No. 11 (1936): 334.

7 Benjamin Brawley, The Negro Genius: A New Appraisal of the Achievement of the American Negro in Literature and the Fine Arts (New York: Biblo and Tannen, 1972 [original 1937]), p. 326.

8 This school is now called the School of the Museum of Fine Arts.

9 Interview with he author, Ms. Sammie Whiting-Ellis, August 14, 1998; Program Notes For the Blessing and Dedication of Mosaic Head of Christ by Samuel Albert Countee, The Lutheran Church of The Epiphany,

Hempstead New York, copy received from Ms. Sammie Whiting-Ellis.

${ }^{10}$ Ibid.

11 Museum School Records, "Samuel Countee," (Boston: School of the Museum of Fine Arts, ca. 1942); Cederholm, p. 62.

12 Museum School Records; Interment Records, Veterans Hospital Cemetery, Farmingdale, New York.

${ }^{13}$ Interview by Ms. Sammie Whiting-Ellis with personnel of the U.S. Army Records Center, St. Louis, Missouri. 
Wood. His college education would have separated him from his generally uneducated peers in basic, and it is very possible that when he graduated from basic training he became part of the cadre, was assigned to an administrative section, or was assigned directly into the 436th Engineer General Service Dump Truck Company. In any case, Countee was part of the 436th by December 1943 , according to a payroll record. ${ }^{14}$ By that time, the 436th was in Iran, along with Staff Sergeant Countee.

In Iran, with the Persian Gulf Command, the 436th and Sergeant Countee were part of the mission to provide supplies to Russia through the Persian Corridor. ${ }^{15}$ A newspaper article in the family's possession indicates that at one time while there Countee was assigned to paint murals in the palace of the Shah of Iran.

Countee's college records, his one payroll record in December 1943, the newspaper account of the expansion of Building 2101, all seem to bracket the date of the mural's creation to between April 1943, when the addition was built, and no later than November of that same year (assuming that it would have taken several weeks to arrive in Iran). However, it is also possible that the mural was painted in 1945. In April 1945, the 436th returned to the United States and was assigned to the 7th Group at Fort Leonard Wood. ${ }^{16}$ Countee was discharged from the Army on October 3, 1945. If Countee was still with the 436th that April, he could have painted the mural between April and October of that year. According to his living sister, the landscape used in the mural in Building 2101 is the north-looking view from his mother's house. Countee was known to use such themes from real life in many of his paintings. For instance, his sketchbooks show that the female and male figures in the Fort Leonard Wood mural were repeated in his other works. One sketch, for instance, uses a vaguely similar setting, except it depicts the female offering the male an apple, capturing the bible story of Adam and Eve.

The war must have had a profound impact on Samuel Countee's life. This is supposed because, from being seen as a rising young black artist prior to the war, Countee seems to have disappeared from the view of the art world in the 1950s. At least the published references in indexes to black artists either do not include Countee, as is often the case in the latest indices, or include only rare references to work after 1943. In those few post-1943 references to Countee, most simply refer to earlier work. His only published work recognized by these indexes is Little Brown Boy published in Alain Locke's, The Negro In Art. ${ }^{17}$ Why he is not more widely recognized is a research topic for the future.

${ }^{14}$ Payroll of the 436th Engineer Company (DT) (St. Louis, Missouri: on file, U.S. Army Records Center). 15 T.H. Vial Motter, The Persian Corridor and Aid To Russia, United States Army In World War II (Washington DC: Office of the Chief of Military History, 1952); Lee, Employment, p. 622.

${ }^{16}$ Anon. "Cards": In a previous printing of this report, the author stated that the 1943 date was "secure" because it was unlikely that the 436th returned to Fort Leonard Wood. But new data indicates that the unit was indeed assigned to Fort Leonard Wood in April 1945. Still, the date on the mural looks more like a "3" than a "5." ${ }^{17}$ Alain Locke, The Negro In Art (New York: Association In Negro Folk Education, 1940), p. 110, 131. 
Regardless, Countee made his way to New York immediately after the war and studied art at New York University School of Education from 1946 until 1947. Sometime during this period he settled into a brownstone in Gramarcy Park. The house was owned by Edward Balch Alford, "a friend, art gallery owner, millionaire, amateur actor and sometimes patron" of both Countee and close friend William Greaves. ${ }^{18}$ Countee and Greaves lived on the third floor, splitting a suite of rooms, while the top floor became Countee's studio. Greaves states that Samuel was a "mentor" to him, and was a major influence in Greaves' decision to become a film producer/director. ${ }^{19}$ Today, Greaves is widely recognized for his work on over 200 documentary films, and was the Executive Producer of the network television series, Black Journal. Greaves has also produced major motion picture films including Bustin' Loose. ${ }^{20}$

Countee continued to exhibit his paintings, taking first prize at an Atlanta show in 1952. But beyond that he appears primarily to have settled into teaching art and painting portraits. In 1955, Samuel Countee was married to Mary Miner and they lived in the New York area, their last address being Hempstead, New York, on Long Island. Samuel Countee died of cancer on September 11, 1959, at the young age of 50. According to his obituary, Samuel was at that time a portrait artist and also gave private art instruction. He was also an art instructor at Public School 619 and donated time to teaching art to narcotic addicts on North Brother Island in the Bronx. He was survived by two sisters, a brother, and his wife, Mary. ${ }^{21}$ Mary remarried in 1977 but died in 1996. However his two sisters, Bernice Yates Sweeney and Martha Countee-Whiting and his brother, Rutherford A. Countee, are still living. ${ }^{22}$

As mentioned, although the art world through the 1950s and 1960s seems to have largely ignored Samuel Countee, he was in fact a prolific artist. ${ }^{23}$ Many of his paintings are still in the private hands of friends and relatives. But examples of this work in the public domain include murals at the former Bishop College in Marshall and Dallas, Texas. A religious man, he painted I Remember the Cross for the Antioch Baptist Church in Houston where he was a life-long member. Another painting of his, Mosaic Head of Christ, is at the Epiphany Lutheran Church in Hempstead, Long Island. This was dedicated to the church in his memory by his wife. ${ }^{24}$ Also two of his works are known to exist at an art gallery in Los Angeles, one of which is entitled Bust of

\footnotetext{
${ }_{18}$ Letter From Mr. William Greaves to the author, October 16, 1998.

${ }^{19}$ William Greaves, Interview with Author, July 7, 1998.

${ }^{20}$ Resume of William Greaves (New York: William Greaves Productions, Inc.); Telephone Interview with William Greaves, July 7, 1998.

21 "Samuel A. Countee," Obituary, The New York Times, September 13, 1959, p. 83; Mr. Donald Smith, Telephone Interview with the author, July 7, 1998.

22 Interviews with the author, Ms. Sammie Whiting-Ellis, July and August 1998.

${ }^{23}$ Countee may have had an established following in the New York area and been widely recognized. What is meant by this statement is that widely available published sources of black art history do not mention Countee. Why that is, again, is a research question for the future. Although not trained as an art critic, from the author's perspective, Countee's art is distinctive, interesting and unique.

${ }_{24}$ Program Notes; Flyer, I Remember The Cross, Yates Printing Company, copy in possession of Sammie Whiting-Ellis.
} 
Booker T. Washington, and is valued at $\$ 9,000.00 .^{25}$ Finally, Fisk University has a painting by him entitled The Lamp.

\section{Army Art At Fort Leonard Wood}

It is highly ironic that Samuel Countee's mural has survived given the circumstances of art expression at Fort Leonard Wood during World War II. At the beginning of the 1940s, the Secretary of War appointed Frederick H. Osborn, businessman and philanthropist, as Chairman of the War Department's Committee on Education, Recreation, and Community Service. His job was to oversee soldier morale. Osborn (later Brigadier General Osborn) and the War Department soon learned that soldiers were not making full use of the recreation halls and other off-duty facilities available to them at the many new installations springing-up across the nation. Despite being new, the standardized temporary buildings built at these installations were rather drab, dull, uninspiring and unattractive. Recognizing that how a soldier spent his off-duty hours had a direct relationship to his morale on the job, Osborn turned to the Facilities Section of Special Services to find ways to attract the soldiers to these facilities. A program was established to find and use talented artists and craftsmen to decorate thousands of day-rooms, recreation halls, and clubs. Its expressed purpose was to "provide an environment that would reflect the military tradition, accomplishments and high standard of army life."26

The program was first tested at Camp Davis, North Carolina and at Fort Belvoir, Virginia. Soon other installations were requesting the program and it is obvious that Fort Leonard Wood was among these installations. Numerous issues of the WWII era Fort Wood News are full of photographs and articles about murals being completed all over the post. Examples and artists abound and include Corporal Frederic James, who painted a mural for Service Club Number 2, Corporal Ken Nishi, who painted a mural in Service Club No.1, Private John V. Ciofalo, who painted a mural in the 35th Battalion recreation hall, Private Leslie Fliegel, who painted his mural at the Red Cross recreation hall, and Staff Sergeant Lyle C. Terry, who designed and executed art for stage settings on post. These are just a few of the artists on post. A newspaper photograph of one of Corporal Nishi's murals depicted a rural Missouri scene with a black farmer, and Private Ciofalo's mural was a salute to "Negro Engineers." ${ }^{17}$ Other artists named in the various issues of the Fort Wood News over the course of the war include: Private James R. Payne, Private Kenneth Nack, Albert Sproill, Robert Davenport, Private Waldo Kaufer, Private William Seay, Private Mario Dos Remedios, Private John Sidrone, and Private Anthony de Stefano.

${ }^{25}$ Countee painted this work for his high school.

26 "Over 50 Years of Serving Soldiers," Website of the U.S. Army Community and Family Support Center, Arts and Crafts Section (www.tiol.redstone.army.mil/mwr/recreation/arts_crafts/new_history.html, 1998).

27 "Mass Production Here Too," 12 March 1943; "Library Mural Completed," 9 April 1943; "Salute to Negro Engineers," 2 July 1943; "Mural for Hospital Rec Building," 21 April 1944; "Works of Art for Doughboys," 10 November 1944; all Fort Wood News (Fort Leonard Wood, Missouri: History Office, U.S. Army Engineer Center) and (Carlisle Barracks, Pennsylvania: microfilm, U.S. Military History Institute). 
Note that Samuel Countee is not among the artists mentioned above in the Fort Wood News. One is almost forced to conclude that the reason was that Countee was a black artist painting at a building set aside for black officers. All of the artists whose pictures appear in the Fort Wood News (admittedly not all do) are white. However, black soldiers are mentioned prominently in many news articles about sports and other recognitions, and it would be wrong to state that their accomplishments were overlooked in the Fort Wood News. Furthermore, black artists painted murals at other posts and they received attention, at least in national black newspapers. In a June 17, 1944, issue of the Chicago Defender an article entitled "Soldier-Artist Highly Praised" relates the success of black mural painter Sergeant Gilbert Cartiero. Another black soldier artist was praised for his mural at Fort Bragg. ${ }^{28}$ Countee himself was written about while painting in Iran. Furthermore, Tech 5 Richard Morton, who was stationed at Fort Leonard Wood, and whose art was recognized and published by Infantry Journal in their book GI Sketch Book, was not mentioned in the news accounts either. So Countee was not the only artist whose works did not appear in the Fort Wood News. ${ }^{29}$ Finally, not all the issues of the Fort Wood News still exist. The irony though is clear, of all the many murals and paintings that were painted at the fort during the war, only Countee's and a Prisoner of War mural still exist today.

\section{Summary}

Talented young black artist Samuel Countee entered the U.S. Army in 1942 and took his place in the segregated ranks along with thousands of black men. Like those other thousands, he was trained at Fort Leonard Wood and was assigned to a service unit rather than a combat unit. But while at Fort Leonard Wood, some currently unknown circumstance or someone gave him the opportunity to paint the mural in Building 2101. Quite possibly this mural may have been the catalyst from which the U.S. Army began to recognize his talent. From there he well may have been assigned other art duties like the murals in Iran, serving in a capacity that made use of his unique gifts.

Much later, Samuel Countee began to receive a wider recognition for his skills. In 1982, the Bishop College Alumni Association named him to their Hall of Fame. Today, one of his paintings, appraised at $\$ 9,000.00$, is for sale in Los Angeles. As the years go by, the larger world is very likely to awaken to the art of Samuel Countee. Hopefully, the discovery that he painted the mural at Building 2101 at Fort Leonard Wood will be part of this awakening. Certainly the identification of Countee as the mural's artist should enhance the mural's value, both monetarily and culturally, and perhaps the mural can assist in a growing interest of Countee's art. Fort Leonard Wood is to be commended for its continuing interest in the mural, its restoration, and its preservation.

28 "Soldier Artist Highly Praised," The Chicago Defender, 17 June 1944, p. 7; "Soldier Artist Uses Talent at Fort Bragg," The Pittsburgh Courier, 13 December 1941.

${ }^{29}$ Aimee' Crane, G.I. Sketch Book, Fighting Forces Penguin Special, (Washington DC: Infantry Journal, 1944). 


\section{CHAPTER VI: THE SIGNIFICANCE OF BUILDING 2101 AND ITS MURAL}

Building 2101, a WWII period modified A-12 temporary building, stands today as a symbol of a significant group of black men who persisted through a unique situation in the long struggle for black civil rights in the United States. The Missouri State Historic Preservation Office has stated that the building is eligible for listing on the National Register of Historic Places under Criterion $\mathrm{A}$, in being associated with events that have made a significant contribution to the broad patterns of our history, specifically under the category of "Social and Military History." The Office has further stated that the mural is also eligible under Criterion A, Art, "as an important example of the work of a noted African American artist."1 The building is eligible at the national level of significance, while the painting has been declared eligible at the state level. This final chapter summarizes the research findings and provides statements of significance for use in nominating the site to the National Register of Historic Places.

\section{Social and Military History}

In contributing to social and military history, Building 2101 stands in testimony to the struggle of black officers of WWII to maintain a leadership presence in an army that was conflicted by their very presence. The black officer in WWII was a dilemma to the U.S. Army--a dilemma to policy makers, to both those who opposed and to those who supported their contribution, and to their race. What to do with the black officer was a question that, ultimately, could not be solved during the war, because its solution was full integration, thereby making the black officer transparent in the officer corps. Until that time came, the black officer stood to remind the nation that a contributing segment of its population was being set-aside from full membership. Today, the black officer in the U.S. Army is transparent, holding positions of leadership throughout the Department of Defense. But during WWII, his position was tenuous and rare, standing apart from fellow officers. Building 2101, although seemingly unpretentious in appearance, stands as a reminder of a period when, while the nation was vigorously challenging the continued existence of two of the most racially intolerant societies in the 20th Century (Nazi Germany and Imperial Japan), it was at the same time struggling with inequality at home.

United States military policy toward blacks from its establishment until the 1960s was overarched by attitudes and prejudices in American society. Advances and declines in civil rights were generally reflected in the military. Technically, it was not the Army's responsibility or mission to change these prejudices, and given the circumstances, there is clear evidence that its

${ }^{1}$ Letter, Claire F. Blackwell, Director and Deputy State Historic Preservation Officer, Missouri Historic Preservation Office, to Dr. Richard Edging, HPM/Archaeologist, Fort Leonard Wood, 21 August 1998. 
official policies sometimes were more enlightened than those in the civilian world. Still, throughout some 370 years of American history the prevailing sentiments toward blacks in society influenced the Army policy and often disrupted its military mission. Of particular relevance here is the Army policy of segregation. As a result of a long standing tradition of segregation between whites and blacks, the mobilization, assignment, care, housing, and welfare of America's soldiers was made unnecessarily complex. Furthermore, societal prejudices had limited the educational opportunities for blacks, making the job of turning black men into soldiers especially difficult. When the black man failed, as he was judged to have done in WWI, prejudices did not allow for unbiased examination of the problem, but only reinforced long held beliefs. By WWII, the Army had come to terms with the realization that the black soldier was needed and must contribute to the defense of the nation, but was still left with the biases of a segregated world. The challenge was how to utilize the black soldier given society's restraints and years of neglect. One of the most complex manifestations of this difficulty was the dilemma of the black officer.

The black officer of WWII was often a well educated and talented individual who had seen success in civilian life. Even those from the ranks sent to OCS had overcome an obstacle that few of their brethren had hurdled. Many were from the north, but were posted to numerous installations established across the Jim Crow South. Black officers expected and deserved the respect and leadership opportunities due their rank, but they represented something many Americans were not ready to accept--a black man in a position of authority. The black officer was abhorred by white supremacists, doubted by black enlisted, and misunderstood by whites sympathetic to their dilemma. White enlisted often refused to respect black officer rank, while black enlisted saw the reactions of whites to black officers and were confused as to the seriousness of the Army's policy toward black officers. Some, perhaps many, white officers also refused to respect black officers' rank and duties. Other white officers and enlisted tried to work with and assist black officers, but would find themselves at risk for their own advancement, or were snubbed by suspicious black officers. Black officers were treated with contempt, gradually began to expect contempt, and reacted in ways which only added to the problem. Thus, the black officer in WWII was highly sensitive and highly aware of his odd place in the Army and in society. The black officer was a enigma to both the Army and himself.

With this kind of conflict, and with long standing traditions entrenched, the Army was still committed to a black officer corps, but left much of the mechanisms regarding their assignment and especially their housing to installation and unit commanders. This left the black officer in the hands of local white commanders and the personal views of these commanders were highly variable. With few black officers before the war, and relatively few black men and women commissioned during the war, commanders were largely inexperienced in dealing with black officers. Sometimes a commander's solution was to post them elsewhere--make them some other commander's problem. Often the solution was not to do anything or find only limited safe assignments for black officers. Consequently throughout the war, the black officer often found 
himself with no challenging command or duty. Installations expecting large numbers of black officers like Fort Leonard Wood could not ignore the black officer dilemma. Although not much is known about Fort Leonard Wood's solution to these problems, it is clear that black officers were given command assignments and cadre positions in training and service units. One officer was given a command of a troop train, not the most exciting or desired duty, but an essential command with considerable independence often given young officers to prove their mettle. Importantly, it was not a make-work assignment.

Providing housing and recreational facilities for the large black officer contingent at Fort Leonard Wood was an additional problem. The installation usually housed its black officers in a separate barracks. If a reference card can be believed though, Fort Leonard Wood at one time had 84 black officers in excess, and it would appear that they may have been housed with white officers at that time. Certainly Building 2100 could not have held all 84-plus officers. The officers' mess was definitely integrated, but white and black officers would not mix, normally sitting at separate tables.

All the above leads to the Black Officers' Club, Building 2101. Officers' clubs were important to an officer's career, a place where bonds were formed with fellow officers that could lead to advancement. It was also a place where superior and junior officers could meet informally to solve potential problems before they became official. The socializing in officers' clubs could be as critical as what happened on the parade ground. Routinely, black officers were barred from these buildings, and thus barred from the socializing necessary for career building, the opportunity for informal correction, and for forging bonds with superior officers. On posts with large numbers of black officers they still were denied use of the installation club, but could not be ignored nor denied recreational facilities as could happen at installations with only one or two black officers. Tradition still demanded that officers have a club, and it must be separate from the enlisted and noncommissioned officers. So at Fort Leonard Wood a separate officers' club was established. Its establishment could have been the result of an incident at the installation officers' club. However, given the relatively large number of black officers on post (perhaps as many as 300 over the course of the war), either they would use the installation club--an unlikely outcome given what is known about the relationship between white and black officers on post--or a club for black officers had to be established. The commander, either General Grant or Colonel Besson, chose the latter probably to avoid potential problems. The reorganization of the ERTC in 1942 probably provided a convenient mechanism for Building 2101 and Building 2102 to be converted to clubs for black officers and NCOs.

Once designated, the Black Officers' Club (officially the Officers' Club Annex, Building 2101) became a quiet respite from the stresses of being a black officer. Here, the black engineer officer met friendly faces and strengthened bonds that were denied by being banned from the installation's officers' club. These bonds would have been especially tight. These black officers 
would most likely meet at other posts and work together again, for one thing. For another they were a select few. But the greater the adversity, the stronger are bonds formed, and under the extreme adversity of being a black officer, one has to conclude that a brotherhood was formed at Building 2101. Friendships established at the Black Officers' Club probably held long after the war. Likely, these bonds were forged under Samuel Countee's mural, which still graces the building's fireplace mantel. Within the walls of the building, around the hearth, and beneath this painting, black engineer officers drew Strength for the Fight as Bernard C. Nalty entitled his 1986 book on the history of black Americans in the military.

\section{Art}

Building 2101 is also significant for its mural, a poignant exhibition of the building's association with black officers in WWII. Indeed, the mural itself is significant for its historic contributions. ${ }^{2}$ The mural is a rare surviving example of WWII soldier art, a short-lived, but at the time highly visible and creative art form. Soldier art was painted by thousands of talented professional and amateur-artists-turned-soldiers for a number of reasons including softening the rough interiors of stark military temporary buildings, inspiring the troops to greater effort, and to remind them of the war's mission. Often painted on impermeable mediums, this art form probably was not expected to remain for posterity, and although the number is not known, there must be few surviving examples remaining today. The mural's subject, a black couple at picnic in an imaginary meadow, served to remind black officers of, perhaps, better days before the war and hope for better days to come. The mural's subject, location, and meaning to the black officers who gathered under it, and its symbolism today make it an object of significance to the history of the black soldier.

An evaluation of the mural's contribution to the world of black art cannot made in this report. However, the discovery that the mural was painted by black artist Samuel Albert Countee certainly lends significance to both the building and the mural from a historical perspective. Countee was an artist of recognized talent and great potential in the 1930s. Yet, at Fort Leonard Wood, scant documentary evidence known to date indicates that he was there simply as a soldier, not because of his artistry. Although speculative, it is thus reasonable to assume that Countee volunteered his time to paint the mural rather than being assigned the task. In fact, the mural may have been the opportunity whereby Countee was recognized by the Army and later given the mission in Iran to paint and restore murals there. Why his work, which still graces churches and colleges across the nation, and is valued in the thousands by art dealers, is just now becoming widely recognized is a question for future researchers. However, what has been learned is that Countee was a prolific artist of unique talent. As his life and work is better appreciated in the future, the mural at Fort Leonard Wood will only gain in its significance both in the art world and within the framework of the National Register.

${ }^{2}$ Here the author is arguing the mural's historic value as a contribution to American black art, black military history, and its value in association with a rare type of art--soldier art. The author has no expertise to evaluate the mural's artistic qualities, but recommends that an expert does so in the future. 
Critically, Building 2101 and its historic importance would be lost today save for the paneled mural on the rear wall of the wing addition. There is nothing about the building physically, save the mural, that speaks to the building's history. As has been seen there is very little in the documentary record testifying to the building's use as a Black Officers' Club except scraps of evidence that quite possibly would not have come to light on their own. It is the mural's dramatic presence that brings historical questions to the mind of the viewer, asking what happened here, why is the mural here? Because of the mural, Building 2101 is recognized today for what it was, a social club for Black Officers' in WWII. The mural is an intrinsic part of the building and together they represent a significant and distinguishable entity. Together the mural, the building and the building's history build an argument for significance at the National Level. Furthermore, for that very reason, the mural cannot be separated from the building, for to do so would destroy the building's historic context, not to mention the very probable destruction of this fragile example of soldier art.

Adding to these elements, the building's exterior landscaping contains rare examples of German POW stonework including a stone fireplace (both internal and external) built by German POWs. The significance of these works are argued in the appendix to this report. However, here it is necessary to point to the fact that the quality of the craftsmanship is very high and bonds the surrounding landscape to the building and its significance. The association between the building and the stonework is, besides their physical attachment, that few other buildings on the post were given such extensive treatment. The landscaping around the headquarters buildings and cemeteries, and the amphitheater, rival the landscaping around the Black Officers' club in terms of sheer effort involved. But in terms of variety of edifices, walkways, erosion control, a large chimney and fireplace, the Black Officers' Club stands alone. Consequently, the stonework adds a level of symbolic respectability due officers and persons in authority not normally associated with that given black officers at the time, and a permanent ambiance to a planned temporary building. Although it can be argued that the one thing that POWs had in abundance was time, there is still a sweet irony and a significance to the fact that so much time and labor was devoted to a building that provided a haven for a displaced people and could not even be named what it was, a Black Officers' Club. The irony and symbolism of this effort and the stonework itself (however subconscious) in comparison with the other buildings housing white officers and headquarters on post cannot have been lost to all those who passed. In this way, the stonework contributes to the building's significance, beyond that of being well-crafted.

\section{Final Summary Statement}

It is important not to view Building 2101 as a seemingly minor representation in the larger picture of civil rights. The symbolism of a separate club for black officers spoke volumes to blacks everywhere about the military's regard for black officers. No doubt black officers were pleased to have a place of their own to go and relax, but at the same time, their own building did nothing to 
improve their image among the men, or their chances to change their situation through social interaction with fellow officers. Some black officers may not have wanted to enter the white officers' club or associate with white officers, but all must have regarded the necessity of a separate club as degrading. Thus again, the presence of the building represented then, and represents now, not only the dilemma of the black officer but also their struggle for civil rights.

It is impossible to measure the contribution that black officers made to the war effort. It could be argued that, given the larger world perspective, their individual contributions were minimal. However, for this band of brothers, which struggled simply for respect and equal opportunity in the U.S. Army Engineers, Building 2101 stands as one of the few, probably only, extant edifices that remind us of that struggle. The civil rights struggle of black officers in WWII, regardless its success or lack thereof, laid the foundation for integration in the military during the 1950s merely by the presence of these officers and their insistence in being given the opportunity for leadership. In this regard, their efforts and Building 2101 are significant. 


\begin{abstract}
ANNOTATED BIBLIOGRAPHY
The quantity of reference material available pertaining to the research in this report is at opposite extremes according to topic. There is a rapidly expanding body of published works on black military history including the World War II period. It seems that each month new histories are announced in press flyers. Although many published secondary sources were consulted during this and previous research projects on black history, I have listed below only those sources cited. Even a partially complete bibliography of black military history would be a project in itself and the author invites readers to refer to the bibliographies of published materials below as good examples. At the opposite end of the spectrum the author found only two published sources concerning Fort Leonard Wood and the ERTC/ ASFTC; these are Larry Roberts' excellent chapter in Builders and Fighters and Coll, Keith, and Rosenthal's Troops and Equipment. Primary sources are equally rare and also incomplete and scattered in archives across the country. The scarcity of primary data concerning blacks at Fort Leonard Wood, and Fort Leonard Wood's role in WWII, is clearly evidenced in the published works. Fort Leonard Wood is almost never mentioned in these works, and if at all, it is usually in passing. There are no historical works on the fort itself, and few on the engineers. In this latter category are mostly unit histories and few are published. All primary sources that were examined, consulted, and cited, have been listed below along with some brief commentary for future researchers.
\end{abstract}

It is indeed unfortunate that the documents concerning blacks at Fort Leonard Wood are so scarce, and that while there are some records of the fort, they too are rare. It appears to the author that the fort has maintained much of its WWII cantonment area, not the least of which is the 7th Group's housing area, its streets, its POW stonework, and a large number of WWII temporary buildings. Fort Leonard Wood has great potential for preserving an important physical memory of WWII. As its documentary memory is weak, the cultural resources become even more significant.

\title{
Published Works, Books, Articles Cited
}

The following published sources were cited and should be available through any large university library.

Aden, Alonzon J. "Educational Tour Through the Hall of Negro Life," The Southern Workman, LXV, No. 11(1936): 331-341.

"Corps of Engineers," Army Navy Journal, 31 May (1941). 
Barbeau, Arthur E. and Florette Henri. The Unknown Soldiers: Black American Troops in World War I. Philadelphia: Temple University Press, 1974.

Brawley, Benjamin. The Negro Genius: A New Appraisal of the Achievement of the American Negro in Literature and the Fine Arts. New York: Biblo and Tannen, 1972.

Buchanan, A. Russell. Black Americans in World War II. Santa Barbara, California: Clio Books, 1977.

Cederholm, Theresa Dickason, editor. Afro-American Artists. Boston: The Boston Public Library, 1973.

Coll, Blanche D., Jean E. Keith, and Herbert H. Rosenthal. The Corps of Engineers: Troops and Equipment. United States Army in World War II, The Technical Services, Washington D.C.: Office of the Chief of Military History, 1958.

Colson, Lieutenants W.N., and A.B. Nutt. "The Failure of the Ninety-Second Division," The Messenger, September (1919):22-25.

Hastie, William H. "Negro Officers in Two World Wars," Journal of Negro Education 12 (1943):312-323.

Henderson, Rose. "Negro Artists in the Fifth Harmon Exhibition," The Southern Workman LXII, No. 4:(1933):175-181.

Herman, Fred W. "Fort Leonard Wood, Missouri," The Military Engineer XXXIII, No. 188 (1941):108-110.

Igoe, Lynn Moddy, 250 years of Afro-American Art: An Annotated Bibliography. New York: R.R. Bowker Company, 1981.

Soldier Art, Fighting Forces Series, Infantry Journal, Inc., 1945.

Johansen, Ralph S. "Training a Selectee to be an Engineer Soldier," The Military Engineer, Vol. XXXIII, no. 188 (1941):105.

Johnson, Lieutenant Colonel Jessie J. Ebony Brass: An Autobiography of Negro Frustration and Aspiration. New York: The William-Frederick Press, 1967. 
Lee, Ulysses. The Employment of Negro Troops. United States Army In World War II, Special Studies, Washington: Office of the Chief of Military History, United States Army, 1966.

Lerwill, Leonard Lieutenant Colonel, The Personnel Replacement System in the United States Army. Washington D.C: Center of Military History, original 1954, reprint 1982.

Locke, Alain. The Negro In Art. New York: Association In Negro Folk Education, 1940.

MacGregor, Morris J. and Bernard C. Nalty editors. Blacks in the United States Armed Forces, Basic Documents, Volume IV, Segregation Entrenched. Wilmington, Delaware: Scholarly Resources, Inc., 1977.

MacGregor, Morris J. Jr. Integration of the Armed Forces 1940-1965. Defense Study Series, Washington: Center of Military History, United States Army, 1981.

McGuire, Phillip. Taps for a Jim Crow Army, Letters from Black Soldiers in World War II. Santa Barbara, California: ABC-Clio, Inc., 1983.

Millett, John D. The Organization and Role of the Army Service Forces. United States Army in World War II, Washington D.C.: Office of the Chief of Military History, 1954.

Motter, T.H. Vail, The Persian Corridor and Aid To Russia. United States Army in World War II, Washington D.C.: Office of the Chief of Military History, 1952.

Nalty, Bernard C. Strength For the Fight. New York: The Free Press, 1986.

Nelson, Joseph. Backwoods Teacher. Philadelphia: J.B. Lippincott Company, 1949.

Reynolds, Grant. "What the Negro Soldier Thinks About This War," The Crisis Volume 51, No.9 (1944):289-291, and No. 10 (1944):316-318.

Roberts, Larry. "The Engineer Replacement Training Center, Fort Leonard Wood, Missouri," in Builders and Fighters: U.S. Army Engineers in World War II, edited Barry W. Fowle. Fort Belvoir, Virginia: Office of History, United States Army Corps of Engineers, 1992.

Scanlan, Tom. Army Times Guide to Army Posts. Harrisburg, Pennsylvania: The Stackpole Company, 1963. 
Scott, Emmett J. Scott's Official History of the American Negro in the World War. New York: Arno Press, Reprint 1969, original 1919.

U.S. Congress, "Fort Leonard Wood, Missouri," Investigation of the Preparedness Program, Twelfth Report, S. Res. 18, 82nd Congress, Document No. 83, Washington D.C.: US Government Printing Office, 1951.

\section{Reports, Theses}

The following are documents of limited distribution. In cases where they might be difficult to find, an additional notation follows the citation.

Army Service Forces. "Fort Leonard Wood, Missouri," Repairs and Utilities Activities, U.S. Army Service Forces, Service Command Conference, 1944. (on file, History Office, U.S. Army Engineer Center, Fort Leonard Wood, Missouri, and the U.S. Military History Institute, Carlisle Barracks, Pennsylvania).

Drummond, Malcolm C., and Richard P. Zerega. Cantonment Historical Resources Survey, Fort Leonard Wood, Missouri. Chesterfield, Missouri: Harland Bartholomew \& Associates, Inc., 1987. (on file, Environmental Office, DPW, Fort Leonard Wood, Missouri).

Garner, John S. World War II Temporary Military Buildings: A Brief History of the Architecture and Planning of Cantonments and Training Stations in the United States. Champaign, Illinois: U.S. Army Construction Engineering Research Laboratories, 1993.

Harland, Bartholomew \& Associates, Inc. Installation Building Survey of April 1992: Report of Findings at Fort Leonard Wood, MO. Army Engineer District Kansas City: April 1992.

Hicks, Douglas C. Masonry Repairs To POW Stonework, Black Officers' Club, Fort Leonard Wood, Missouri. Williamsport, Maryland: Williamsport Preservation Training Center, Harpers Ferry, 1995. (on file, Environmental Office, DPW, Fort Leonard Wood, Missouri).

Hurtt, Colonel C. M. "The Role of Negro Service Units in Word War II," Baltimore: Master's Thesis, Morgan State College, 1972. (Copy on file, vertical files, Center of Military History, Washington D.C.).

Kermath, Don, Amy J. Lamb, Tracy Hewitt, Doug Hicks, Rick Strilky, and Robert Score, Historic Restoration of the Black Officers' Club at Fort Leonard Wood, Missouri. Champaign, Illinois: on file, USACERL, draft manuscript, 1996. 
Snyder, Alan K. Guide to Archival Sources Study of World War II Temporary Buildings, Office of History, U.S. Army Corps of Engineers (National Archives II, College Park, Maryland: on file, 1988.

Smith, Steven D. Made it in the Timber: A Historic Overview of the Fort Leonard Wood Region, 1800-1940, Normal, Illinois: Midwestern Archaeological Research Center, Illinois State University, 1993. (on file, Environmental Office, DPW, Fort Leonard Wood, Missouri).

Smith, Steven D. and James A. Zeidler, editors. A Historic Context For the African American Military Experience, Department of Defense, Legacy Resource Management Program, Champaign, Illinois: Construction Engineering Research Laboratories, 1998.

Wiley, Major Bell I. The Training of Negro Troops, Study No. 36, Historical Section, Army Ground Forces, Washington D.C.: Headquarters Army Ground Forces, 1946.

\section{Manuscripts}

\section{National Archives}

Several record groups at the National Archives were searched or their finding aids reviewed for data concerning Fort Leonard Wood and the Black Officers' Club, Building 2101. After making some decisions about which record groups to search, the author checked his decisions with professional archivists at the National Archives who made additional suggestions, especially after the author had exhausted the more obvious Record Groups. Many military Record Groups are arranged by a decimal system, an Army-wide system which allowed a clerk to file records, letters, memorandums, etc., according to subject heading. For instance RG 160's files pertaining to "Negroes" is Decimal File \# 291.2. This system is no longer used, but old records are still arranged in this manner. The first step was to search these finding aids and have the archivists pull the records from likely subject headings. Few records ended up being cited in the text simply because they had little pertinent information or the information was available elsewhere.

Future researchers are warned that the National Archives military record group holdings are split between the College Park, Maryland, Branch and the Washington D.C. branch. Generally, those records prior to 1942 are found at the Washington D.C. branch, those after 1942 at the College Park Branch. Unfortunately, records pertaining to 1942 are found at both branches. Record Groups searched or finding aids reviewed include:

RG 77 Records of the Office of the Chief Engineers. The author examined the finding aids at National Archives at College Park and Washington D.C. and pulled likely records, such as the 
General Correspondence file, but there was little on Fort Leonard Wood. The archives completion report for Fort Leonard Wood was missing, but was available at Fort Leonard Wood. The Kansas City records were being processed at the time, however the archivist in charge of this work searched the records for the author. Once these are available to the public, it would be useful to check these files again.

RG 92 Records of the Office of Quartermaster General. Pulled pertinent files including some documents relating to Fort Leonard Wood, but nothing pertinent to this research topic.

RG 107 Records of the Secretary of War. Reviewed finding aids and pulled file on Civilian Aide Judge Hastie, facilities.

RG 160 Records of the Headquarters of the Army Service Forces. Reviewed finding aids and pulled files on Fort Leonard Wood and construction reports. Also an archivist found considerable records pertaining to Fort Leonard Wood's deactivation and these were forwarded to the author.

RG 338 Records of the U.S. Army Commands to 1942. Reviewed finding aids and pulled Seventh Army Corps files. Also pulled Camp, Post and Stations files on Fort Leonard Wood.

RG 389 Records of the Office of Provost Marshall. An archivist offered to research this file under "Prisoners of War."

RG 394 Records of the U.S. Army Continental Command 1920-1942. Reviewed finding aids and pulled documents pertaining to Seventh Army Corps, clubs, Negroes, buildings, contracts, administration, general correspondence files.

RG 407 Records of the Adjutant General's Office. Reviewed finding aids and pulled Military Posts and Reservations files.

\section{U.S. Army Military History Institute, Carlisle Barracks}

The author was unable to visit the USAMHI, however, he conducted multiple internet searches and discussed the problem with Institute archivists. These archivists were very helpful and faxed vertical file and card file records to the author for perusal. The only pertinent information found was a microfilm copy of The Fort Wood News, and a service manual, which was also available at Fort Leonard Wood. The Institute is very strong on unit histories, but did not have information on training units. There are also some post-war records of the and 1960s there. 


\section{Center of Military History, Washington D.C.}

This office writes official histories for the U.S. Army. It has extensive holdings. After much searching and assistance from Center historians, the author was able to locate reports concerning the development of the ERTC which were of great aid. Miscellaneous writing on the covers of these reports indicate that they were microfilmed for the National Archives, although neither the author or NA archivists could find them. The center also has vertical files with miscellaneous information about Fort Leonard Wood, most of which pertains to the post WWII period.

Office of the Chief of Military History, Training of Replacements, Fillers, and Cadres, Corps of Engineers, 6 March 1941-30 June 1944 .ca. 1945.

Office of the Chief of Military History, Training of Replacements, Fillers, and Cadres, Corps of Engineers, 1 July 1944-31 December 1944 ca. 1945.

Office of the Chief of Military History, Training of Replacements, Fillers, and Cadres, Corps of Engineers, 1 January 1945-30 June 1945. ca. 1945.

Office of the Chief of Military History, Unit Training in the Corps of Engineers, 1 July 1945-31 December 1945 ca. 1946.

Office of the Chief of Military History, Training of Replacements, Fillers, and Cadres, Corps of Engineers, 1 July 1945 1945-31 December 1945 ca. 1946.

Office of the Chief of Military History, The Schooling of Commissioned Officers by the Corps of Engineers 1 July 1944-31 December 1944, ca. 1945.

Office of the Chief of Military History, The Schooling of Commissioned Officers by the Corps of Engineers 1 January 1945-30 June 1945 ca. 1946.

\section{Historical Society of Washington D.C.}

The Historical Society of Washington D.C. holds the papers of General U.S. Grant III (MS 344). Most of these pertain to his long planning service in Washington. However, an archivist did locate some correspondence pertaining to his command at Fort Leonard Wood and forwarded these to the author. They are letters and speeches given during his command and shortly thereafter. 
There are many other locations of Grant papers, but none appear to have extensive records pertaining to his command of the ERTC. Grant papers exist at Southern Illinois University, Carbondale, Illinois, the Missouri Historical Society, St. Louis, and Hamilton College, New York. The author discussed these records with librarians and archivists and they performed records searches, but nothing pertinent was discovered.

\section{History Office, U.S. Army Engineer Center, Fort Leonard Wood}

The History Office at Fort Leonard Wood proved to be one of the most fruitful archives in conducting this research.

Engineer Replacement Training Center, Administrative Files. These files contain administrative letters and memorandums pertaining to the ERTC at Fort Leonard Wood. Also included are a series of cards developed by an unknown Army historian who was writing the history of the ERTC/ASFTC, part of which at least made up the reports found at the Center of Military History. As noted elsewhere, the actual report for Fort Leonard Wood was not found but rather the reports for all the ERTC's were combined. The letters and memorandums are also copies of, supposedly, the original materials at either the Kansas City Branch of the National Archives, or those in the D.C. area. However, neither the author nor several professional archivists could locate the original materials.

The History Office also has a vertical file on various historical topics pertaining to the installation and to the ERTC. The following miscellaneous records were all found at the History Office.

Fort Leonard Wood Telephone Directories For February 1941, December 1941, January 1943, June 1944, and most years following 1951.

Construction Completion Report, Fort Leonard Wood, June 1941.

"Individual Building Report For Historical Record, Buildings 1652, 1653, 1757, 1759, 1913, 2101, 2102."

Anonymous, "The Construction of Fort Leonard Wood" fact sheet.

Klobe, Harold R. "Fort Leonard Wood, Missouri: Construction and Impact on the Civilian Community 1940-41" 17, November 1993, History 601 research paper, location unknown. 


\section{U.S. Army Engineer Museum, Fort Leonard Wood, Missouri}

The engineer museum at Fort Leonard Wood has few records pertaining to the ERTC. Two souvenir books are on file.

Souvenir Book Engineer Replacement Training Center, Fort Leonard Wood, Missouri. Fort Leonard Wood, Missouri.

Charles J. Wolf Publishers. Fort Leonard Wood E.R.T.C. 1943. St. Louis: Charles J. Wolf, 1943.

\section{Thomas Cooper Library, University of South Carolina, Columbia}

The following manuscript collections were used at the University of South Carolina. These papers are usually available at most large research libraries.

Papers of the NAACP, Part 9, Series B, "Discrimination In The U.S. Armed Forces, 1918-1950," Soldier Complaints, Reel 15, 0510 (University of South Carolina, Columbia: microfilm, Thomas Cooper Library).

Papers of the NAACP, Part 9, Series B, "Discrimination In The U.S. Armed Forces, 1918-1950," Soldier Complaints, Reel 13, 0556. (University of South Carolina, Columbia: microfilm, Thomas Cooper Library).

\section{Newspapers}

The Fort Wood News, 1941-1946. Incomplete hardcopies on file, History Office, U.S. Army Engineer Center, Fort Leonard Wood, Missouri. Microfilm, U.S. Military History Institute, Carlisle Barracks, Pennsylvania and Kinderhook Library, Waynesville, Missouri. 1942 incomplete on microfilm.

The Chicago Defender, 1941-1943. Microfilm, Thomas Cooper Library, University of South Carolina. This was an important black newspaper. The author skimmed the years 1941-1945 for information about Fort Leonard Wood. There was very little about Fort Leonard Wood but there was a great deal of information about blacks at other military posts including Fort Huachuca, Arizona, The Tuskegee Institute, and Fort Bragg, North Carolina.

Pulaski County Democrat. 1941, 1942 and 1944. This was the Pulaski County and city of Waynesville, Missouri newspaper (Fort Leonard Wood is in Pulaski County). The years 1941 and 1942 were skimmed and also a few months of 1944 . There was surprisingly little information about 
nearby Fort Leonard Wood. Later issues devoted a section to news from Fort Leonard Wood, but the articles were taken from the Fort Wood News.

The Pittsburgh Courier, 1942, 1944. Microfilm, Thomas Cooper Library, University of South Carolina. This was another black newspaper. Like the Chicago Defender, it had many articles on blacks at various camps and forts, but little about Fort Leonard Wood. The author looked at the issues for years 1942 and 1944, and then skimmed 1945 to see if there was any change in reporting patterns.

\section{Interviews}

The following people were interviewed regarding Fort Leonard Wood, the ERTC, and Samuel Countee.

Mr. and Mrs. Larry Adkins, Waynesville, Missouri. Mr. Adkins guarded the POWs at Fort Leonard Wood. He was very ill at the time of interview and could not remember what he had already related in an interview conducted 11 years previous. Interview by telephone, March 20th, 1998.

Dr. Kim Combs, U.S. Army Engineer Museum, Fort Leonard Wood. Interview October 15, 1998.

Mr. Perry Cox, Brownwood, Texas. Mr. Cox was at Fort Leonard Wood in May 1941. He was interviewed via telephone on June 15 and 16, 1998.

Dr. Roger Countee, New York, New York. Dr. Countee is a nephew of Samuel Countee. He was interviewed by telephone in July of 1998 .

Ms. Robin Countee, Washington D.C. Ms. Countee is the daughter of Dr. Roger Countee. She was interviewed in July of 1998.

Dr. Martin Gordon, Fort Belvoir, Virginia. Dr. Gordon assisted via e-mail with suggestions regarding primary documents pertaining to Fort Leonard Wood.

Master Sergeant Delanious Gossett. He was at Fort Leonard Wood from May 1941 to January 1942. Interview conducted October, 16, 1997 at Fort Leonard Wood.

Robert Howard. Mr. Howard was at Fort Leonard Wood after WWII and had an office in Building 2101. Interview conducted October, 16, 1997 at Fort Leonard Wood. 
Ms. Mary Jo Loving, Rolla, Missouri. She worked at the Headquarters office of the ERTC. Interview conducted by telephone on March 10, 1998.

Mr. Edward Reep, Bakersfield, California. Mr. Reep was a 2nd lieutenant in the 7th Group and trained black soldiers at Fort Leonard Wood's ERTC from December 1942 to around February 1943. Mr. Reep is a talented artist who was chosen as a combat artist during the war. He has written of his experiences in a book entitled A Combat Artist in World War II (Lexington: University Press of Kentucky, 1987). Mr. Reep saw no black officers or black artist Samuel Countee while there.

Dr. Larry Roberts, History Office, U.S. Army Engineer Center. Dr. Roberts provided extensive and excellent advice throughout this research during several interviews at Fort Leonard Wood and via the telephone.

Mr. Donald Smith, Jamaica, New York. Mr. Smith was the second husband of Mary Countee, widow of Samuel Countee. Mr. Smith was the first link to establishing that Samuel Countee was the artist of the mural and was most helpful. He was interviewed by telephone on several occasions from July 1998 to August 1998.

Ms. Sammie Whiting-Ellis. Ms. Whiting-Ellis is the niece of Samuel Countee and was named for the artist and her father. She was most generous and helpful in numerous interviews from July to September 1998. She also traveled to St. Louis and Fort Leonard Wood, Missouri for research on her uncle. Most of what is related in this report about Samuel Countee is due to her generosity. 


\title{
APPENDIX: GERMAN POW STONEWORK AT FORT LEONARD WOOD, MISSOURI
}

\author{
By Geoffrey C. Burt, Suzanna Walaszek, \\ and Richard Edging \\ Construction Engineering Research Laboratories (CERL), Champaign, Illinois
}

\section{Management Summary}

This report has determined, in concert with the three Harland Bartholomew and Associates reports, that certain examples of German POW-constructed stonework at Fort Leonard Wood are historically significant. This includes the stonework associated with the following areas:

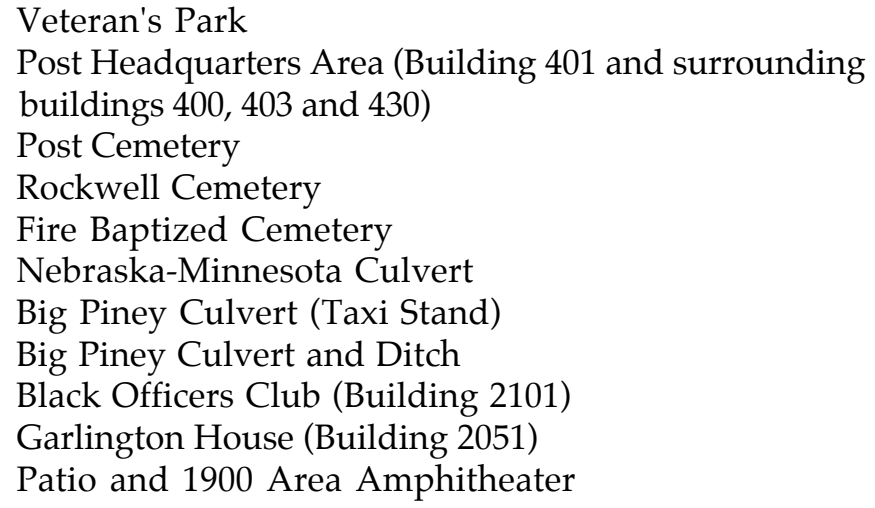

The stonework in these areas is eligible for listing on the National Register of Historic Places under Criterion A: Event, and Criterion C:

Design/Construction. Several of the "minor stone structures" found in the cantonment area may also be included in this list if it can be determined that they are also significant and retain adequate integrity, based on National Register Criteria (this would be determined during the course of the nomination process).

In addition to the determination of significance, it has also been found that the stonework at Fort Leonard Wood possesses adequate integrity, and is over fifty years of age. It is the recommendation of this effort that the next logical step would be to initiate the necessary process to nominate the collection of identified stone features as part of a thematic grouping within a historic district. The stonework would be the dominant resource of the district, but other historic properties and/or resources may be included. In a letter dated 28 July 1998, the Missouri State Historic Preservation Office concurred with this determination and encouraged the Department of the Army to prepare a multiple property nomination for this POW stonework at the National Level of significance. 


\section{Introduction}

As defined in the 1986 Programmatic Memorandum of Agreement among the United Sates Department of Defense, the Advisory Council on Historic Preservation and the National Conference of State Historic Preservation Officers, all WWII temporary buildings were to be demolished except for a representative sampling of buildings to be determined. World War II temporary buildings at Fort Leonard Wood have been progressively demolished over a number of years, beginning with the designation of the fort as a permanent installation in 1956. As new construction projects have been undertaken, the older wood-frame types of buildings have disappeared in increasing numbers. Of the 1,600 temporary buildings built during 1940-1941, 600 remained as of 1987, and that number has been substantially reduced in the last ten years. ${ }^{1}$

As the number of these temporary structures has gradually diminished, the presence of a related resource has acquired increased prominence. This resource, a diverse collection of stonework, was constructed by German prisoners of war (POWs) and to a lesser extent, U.S. troops, at Fort Leonard Wood. The stonework was either related to various buildings as outside foundation walls, chimneys, or patios, or built as separate landscape infrastructure, such as walks, culverts, ditches, or retaining walls. In either case, the stonework was situated and constructed as part of the overall context of the original WWII cantonment. Removal of the associated buildings that represented this cantonment compromises historic significance of the remaining stone features.

Previous surveys and planning documents, prepared by Harland Bartholomew and Associates, have identified, assessed, and provided recommendations for the stone features constructed by German POWs who were detained at Fort Leonard Wood during World War II. ${ }^{2}$ The determination of significance of these features as provided in these reports was primarily based on fragmented criteria such as physical evidence of POW construction, date of construction, unique design characteristics, materials and dimensions, and significant people involved in the sites where the stonework is located. Determinations of eligibility for inclusion to the National Register of Historic Places were made based on the Department of the Army's categories of historic importance, found in Army Regulation 420-40 and Technical Manual TM5-801-1. It was the conclusion of these reports that certain significant stonework features should be nominated to the National Register as part of a thematic nomination, and that other major and minor stonework features are not eligible.

\footnotetext{
${ }^{1}$ Harland Bartholomew and Associates, Installation Building Survey: Report of Findings (Kansas City: District Corps of Engineers, Department of the Army, 1992), p. 35.

${ }^{2}$ Harland Bartholomew and Associates, Installation Building Survey; Harland Bartholomew and Associates, Cantonment Historical Resources Survey (Kansas City: District Corps of Engineers, Department of the Army, 1987); Harland Bartholomew and Associates, Historic Preservation Plan: Final Report (Kansas City: District Corps of Engineers, Department of the Army, 1992).
} 
Since the 1986 MOA only provides guidance on the removal of WWII temporary buildings and not associated landscape features, the stonework construction at Fort Leonard Wood is currently vulnerable to periodic removal and/or other disturbances. It is the intention of this report to provide recommendations for a protection program for these historic resources as well as a summary statement of significance for the stonework at Fort Leonard Wood. The potential for a thematic nomination will be discussed. These supplementary recommendations are to be inserted into appropriate SOPs for the Fort Leonard Wood Cultural Resources Management Plan.

It is also the intention of this effort that, as part of the comprehensive preservation planning process for Fort Leonard Wood, the recommendations of this report will assist in the development of goals and priorities for the identification, evaluation, possible registration, and ultimate treatment of its historic stonework properties. With this in mind, an earlier draft of this report was submitted to the Missouri State Historic Preservation Office in June 1998. The Missouri State Historic Preservation Office concurred with the determination that the stonework was significant and recommended that the Department of the Army prepare a multiple property nomination for the POW stonework. The MSHPO further stated its belief that the stonework is eligible at the national level of significance. ${ }^{3}$

\section{Historic Context}

The prisoner of war camp at Fort Leonard Wood was activated on 8 December 1942 under the title "Enemy Alien Internment Camp", and the first prisoners, 662 Italian soldiers, arrived on the 18th. However, the Italians were transferred to a camp at Weingarten, Missouri, in in early June, 1943, and on June 28, 1943, 800 German POWs arrived at the Fort Leonard Wood Internment camp. The German POW population at Fort Leonard Wood fluctuated considerably throughout World War II, as prisoners were sent to and from various POW camps in 25 states. In August, 1943, the German prisoner population reached the camp's 3,000 man capacity. The peak POW strength occurred in June, 1945, when the prisoner population increased to 5,187 in Missouri. But to keep the numbers within Fort Leonard Wood's prisoner population limits, ten branch camps were established throughout Missouri, accommodating up to 2,000 prisoners. ${ }^{4}$ The camp was discontinued on 20 May 1946, two months after the installation closed.

Most of the POWs at Fort Leonard Wood were veterans of the Afrika Corps. The Afrika Corps were known for strongly supporting a fanatic political philosophy, National Socialism (Nazis). It is estimated that only 10-15 percent of the enlisted men in the German Army were hardcore Nazis. Battles within the POW camps between the ardent Nazis and anti-Nazi prisoners

${ }^{3}$ Letter, Claire F. Blackwell, Missouri Deputy State Historic Preservation Officer, to Dr. Richard Edging, Fort Leonard Wood, Cultural Resource Manager, 28 July 1998.

${ }^{4}$ Harland Bartholomew \& Associates, Inc., Cantonment Historical Resources Survey, (St. Louis, Missouri: 1987), p. 8. 
were common. ${ }^{5}$ However, there are no known major riots or battles at Fort Leonard Wood. The fact that the majority of the German POWs at Fort Leonard Wood were veterans of the Afrika Corps could be why there are relatively few documented cases of conflict within the camps and with the American soldiers. However, there were a few escape attempts. Two soldiers attempted to escape a brush clearing detail on 29 March 1944. They surrendered on 4 April. Shortly there after, two others escaped a labor detail on 24 April and were picked up by police three days later. But Rudolf Krause made the most successful try, escaping on 10 September 1945 and getting to Orlando, Florida, before being recaptured. ${ }^{6}$

The POW confinement area at Fort Leonard Wood was located south of the present day airfield and was divided by barbed-wire fence into three compounds, with each compound designed to hold 100 prisoners. Following the Geneva Convention of 1929, these compounds were built according to American military camp standards. Standard facilities included barracks, latrines, and showers, all of which were single-story, tarpaper covered buildings with tent roofs. The structures were erected on concrete slab foundations or elevated on concrete posts. The camps were guarded by three complete Military Escort Companies posted at Fort Leonard Wood, but otherwise detached from Army Ground Forces or the ERTC. At first the guards were cautious, even mean, as Fritz Ensslin stated "They tried to make themselves look important in the eyes of the girls. To show off, they would sometimes use the stocks of their weapons on us." ${ }^{17}$ Ensslin stated they had the most trouble from "Polish Guards," although it is not clear if he was referring to the guards at Fort Leonard Wood or elsewhere. In any case, as the war progressed, the guards were more lax, and informants have stated that they were so lax that the guards would hand their rifles to the prisoners as they got onto work trucks, and then the prisoners would hand the rifle back to the guard.

Overall the prisoners were well treated, and perhaps another reason why there were few escape attempts was that they were surprised by the wealth and plenty provided them in comparison to their lives in the Afrika Corps. Upon arrival in camp they were given a "dream meal" and allowed to sleep till noon to recover from their trip. During their internment, they were given free access to hot and cold water and "had access to almost unlimited quantities of real curd soap." ${ }^{18}$ They also had free time, and at Fort Leonard Wood the prisoners built a soccer field. Other activities included carving, and making fake German War medals to sell to Americans.

$\overline{5}$ Judith M. Gansberg, Stalag, U.S.A. (New York: Thomas Y. Crowell Company, 1977), pp. 33-35.

6 "Historical Data: Prisoner of War Camp, Fort Leonard Wood, Missouri" (Fort Leonard Wood, Missouri: on file,History Office, U.S. Army Engineer Center, n.d.).

${ }^{7}$ Fritz Ensslin, "Memoirs of a German Prisoner of War In America, " In The Fallen Foe America's German Prisoners of War 1942-1946, Presented by the Fort Leonard Wood Museum (Fort Leonard Wood, Missouri, on file, U.S. Army Engineer Museum).

${ }^{8}$ Ibid., pp. 9-11. 
But mostly they labored. The critical need for conserving manpower in the U.S. Army during WWII made it imperative that POWs be utilized whenever possible to replace American soldiers and civilian personnel. Nationwide, the War Department established a work program that allowed POWs to perform a variety of tasks on Army bases. The prisoners were generally glad to be engaged in tasks that kept them busy and relieved the monotony of prison life. Most of the work focused on general repair, maintenance, and upkeep tasks or service-related activities such as waiting tables, janitorial jobs, and food processing, or administrative/clerical tasks including even post policing. ${ }^{9}$ Although the work program began with the majority of labor being performed directly on Army posts or camps, by 1943 military service and high-paying jobs in the war industry had reduced available manpower enough so that POWs were allowed to perform contract labor offbase. Types of off-base work included all manner of agricultural details, factory work, logging, construction and carpentry, general maintenance, landscaping tasks, flood-control projects, and work in fish hatcheries. ${ }^{10}$

The substantial POW population at Fort Leonard Wood provided a much needed labor force for the installation, and the use of German prisoners for essential tasks in the operation of the fort became common by 1944. Duties performed by POWs at Fort Leonard Wood included various administrative activities, road work, laundry, mechanical and technical tasks, mess hall activities, and logging. Many were employed in landscaping and landscape maintenance. They even painted murals, only one of which survives today at the U.S. Army Engineer Museum. Additionally, government regulations were initiated in 1943 in order to accommodate the need for POW labor outside the installation, which enabled private citizens to employ POWs for farm work or general labor. In order to properly administer the prisoners and ensure compensation to the U.S. government from the private citizens, branch camps were developed and contracts were established between the two parties. Branch camps ranged in size from 50 prisoners to as many as 500 . Prisoners were also transported every day from the Fort Leonard Wood base camp to do farm work in the immediate vicinity. Some 1,500 prisoners were offered to local citizens to perform various farmrelated tasks. On the rural farms of Missouri, the prisoners were well treated, sharing the dinner table and generally treated like any other farm hand.

Although NCOs and officers were not required to work, many did, simply for something to do. For their work prisoners were paid 10 cents a hour in script, which they could use at the POW camp stores to buy soap, safety razors, and peanuts. The men also were issued a ration of two bottles of beer at the end of the day. Such latitude toward German POWs across the nation prompted uncomplimentary comparison by black soldiers about how their own treatment in the Army. ${ }^{11}$

\footnotetext{
${ }_{9}$ George G. Lewis and John Mewha. History of Prisoner of War Utilization by the United Sates Army, 17761945 (Washington, D.C.: Center for Military History, 1988), pp. 146-147.

${ }^{10}$ Gansberg, Stalag, U.S.A. pp. 33-35; Alan Kent Powell Splinters of a Nation: German Prisoners of War in Utah (Salt Lake City: University of Utah Press, 1989), p. 157.

11 cf. Phillip McGuire, Taps for a Jim Crow Army, (Santa Barbara, California: ABC-Clio, Inc., 1983), p. 237.
} 
One additional labor activity of a more skilled nature was that of stonework. The steep topography at Fort Leonard Wood created the need for drainage structures, retaining walls, and sidewalks around the standard mobilization buildings. The German POWs provided a hardworking, available labor source, and the geology of the area provided the necessary sandstone, chert, and gravel. Approximately 10\% of the POW population was involved in stone construction throughout the post. These men were guided by fellow prisoners who were highly experienced German stonemasons.

Five stonework patterns exist among the POW stone structures at Fort Leonard Wood: Coursed Squared, Random Squared, Course Handcut, Random Handcut and Mosaic. The particular design characteristics result from differential stone preparation and stone laying. Roubidoux Sandstone is the dominant type of stone used in the stonework at FLW. It can be quarried locally and is known for its strength and wide range of colors and textures. Some Gasconade Dolomite (a limestone) is also found locally and was used sparingly as decorative rock in large stone walls. Coursed Squared stonework required the most effort in preparing since they were both squared and designed to meet the height characteristics of the courses. An excellent example of this method are the chimneys at the Black Officers' Club and the Garlington House. Random Squared stonework required less stone preparation; however, more time is needed to lay the stones. Random squared

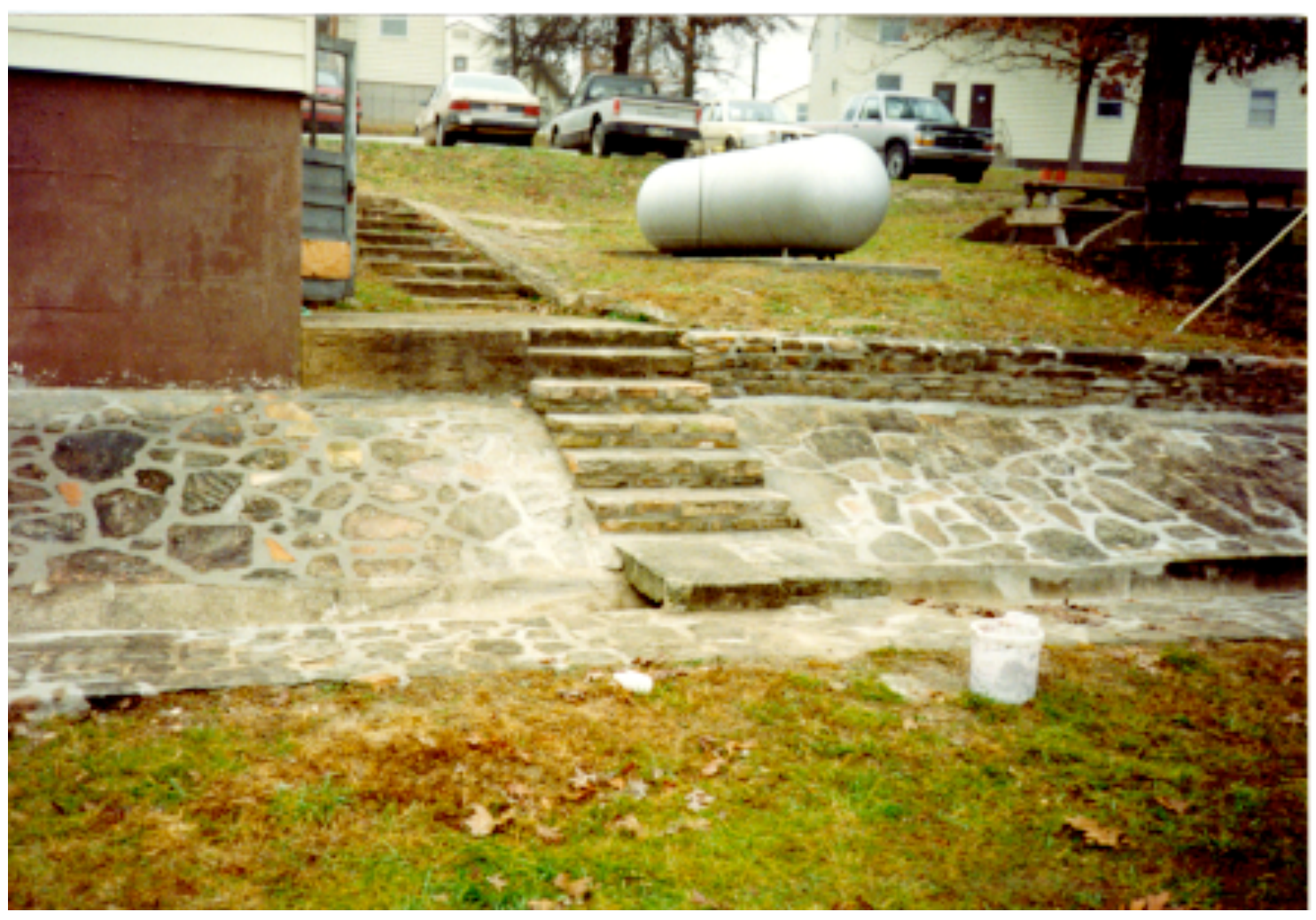

Figure A-1 Stone Steps, Retaining Walls After Restoration, Building 2101 (courtesy USACERL). 
stonework was frequently used for walls and culverts in such places as Veterans Park, the former Post Headquarters (400 area), Post Cemetery, Fire Baptized Cemetery.

Two handcut patterns, coursed and random, had characteristic rough sides and faces that require stones of the same height. Examples of coursed handcut stonework are found in walls at the Big Piney Culvert, the Black Officers' Club and Building 2333 today. Finally, the mosaic stonework pattern was the most common stonework used in the cantonment. Uncut flat stones were laid with mortar into a random pattern that today comprises most of the walks, drainage ditches and patios at Fort Leonard Wood.

Some of the most elaborate and extensive stonework was completed around Building 2101, the Black Officers' Club (Figures A-1, A-2). This work included an

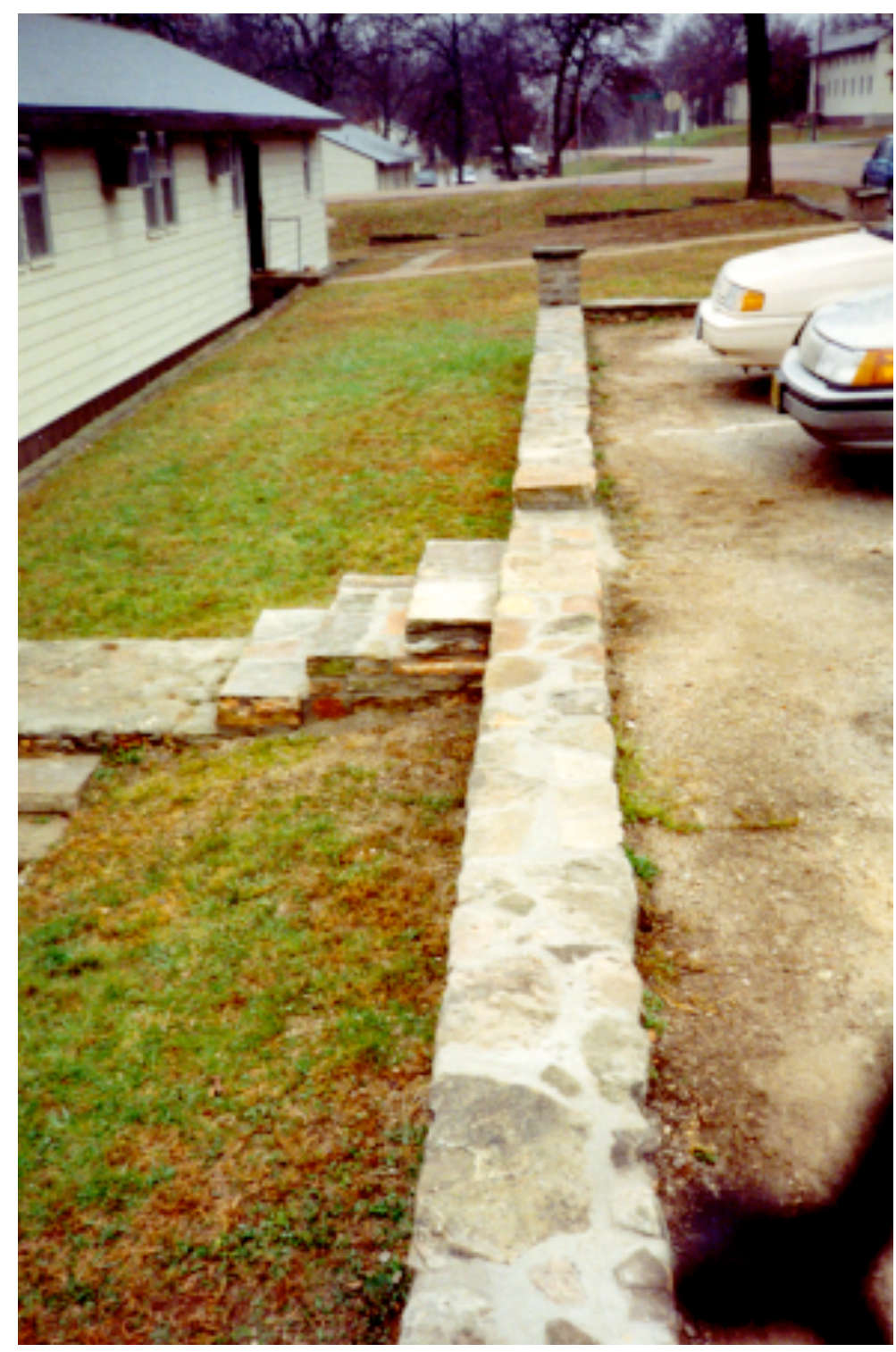

Figure A-2 Restored Wall In Front of Building 2101 (Courtesy USACERL). interior fireplace and exterior chimney, retaining walls on the ravine sides behind the club, decorative walls in front, stone covered embankments, walkways, and ditches. The chimney consists of coursed squared stonework, the fireplace of coursed squared stonework in geometric pattern, walls of coursed handcut stonework and coping, and walks and ditches of mosaic stonework. $^{12}$ The stone chimney has a bas-relief eagle under which is are the words and date "Fort L. Wood, German POWs, 1945," in three lines. In 1994 and 1995 the Department of Defense's Legacy Resource Management Program funded restoration of this stonework and an extant mural inside the Black Officers' Club.

$\overline{12}$ Harland Bartholomew \& Associates, Inc., 1987, p. 26. 
Inventory

The Cantonment Historical Resources Survey by Harland Bartholomew and Associates, 1987 report identified 12 major historic POW-related stone features that may be considered as eligible for inclusion to the National Register. An additional 50 minor stone structures were identified. None were considered eligible but approximately half are deemed worthy of "ongoing maintenance."

The study determined that there is a distinct geographical pattern to the locations of the stone features on the post. They are concentrated in four areas: The Post HQ-First Street-North Dakota subarea in the north-central part of the cantonment area; the Replacement-Second Street subarea in the northeastern part of the cantonment area; the Nebraska-Oklahoma subarea in the eastern part of the cantonment area; and the South Dakota-Artillery Circle subarea south of South Dakota Avenue. Of these, the first three subareas identified contain the 12 major stone structures.

The 12 major stone structures, as identified in this report, are:

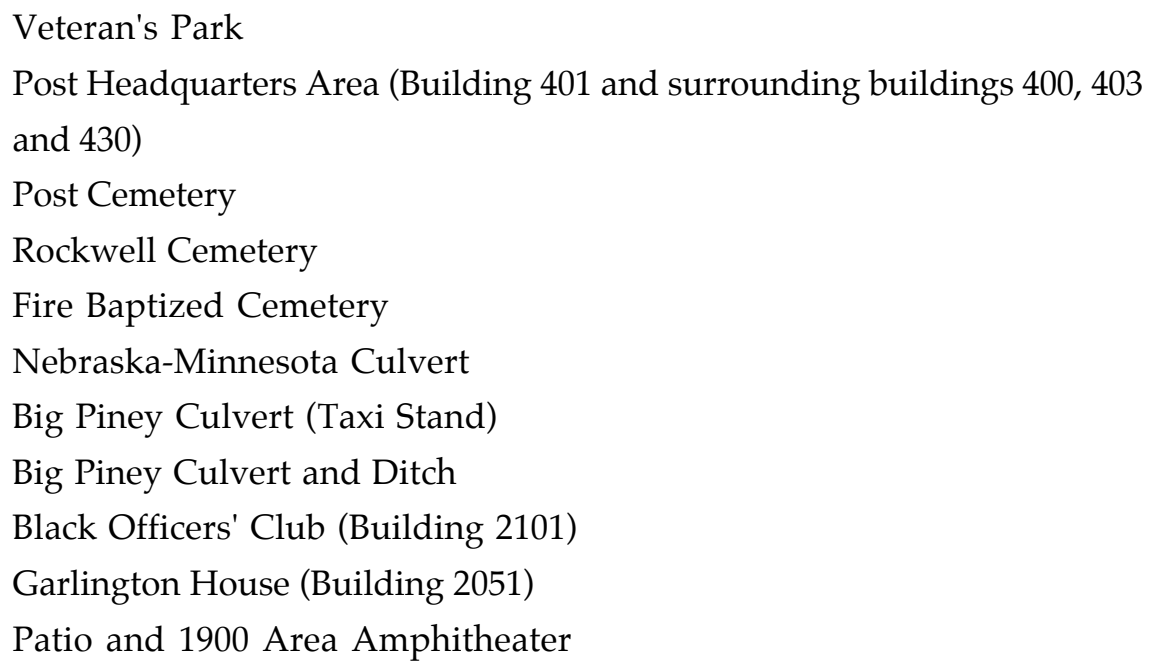

Since this work was completed several years ago, an updated inventory and status report is needed. With this in mind the Construction Engineering Research Laboratories, Champaign, Illinois, and the Directorate of Public Works, Fort Leonard Wood, are currently in the process of completing such a project.

\section{Considerations in the Determination of Historic Significance}

The authors agree with previous work that the stonework represents a significant cultural resource and a synthetic statement of significance needs to be prepared and the stonework 
nominated for inclusion on the National Register of Historic Places. The following considerations are offered to guide that nomination.

Subsequent reports by Harland Bartholomew and Associates reaffirm the significance of the stonework at Fort Leonard Wood. ${ }^{13}$ The reports stress the association with German POW stonemasons, the "special cultural contribution" of the stonework, and its artistic design and construction style (which usually would be considered "ordinary," but is considered unique in this circumstance). Unfortunately, there are several conflicting recommendations in the final evaluations in these reports, thus presenting a challenge to those required to make decisions regarding the future preservation and maintenance of the stonework.

Of the 12 stone structures originally identified as "major" in the 1987 report, four are recommended as potentially eligible for nomination to the National Register of Historic Places in the April 1992 Survey: 1) the Garlington House, 2) the Black Officers' Club, 3) Veterans Park stonework, and 4) the Nebraska-Minnesota Culvert. However, the subsequent 1992 Historic Preservation Plan (HPP) recommends that the Black Officers' Club, Veterans Park stonework, the Nebraska-Minnesota Culvert, and the Post Headquarters area stonework are potentially eligible for nomination. This plan goes further to state that "the following properties are not eligible for the National Register of Historic Places either by themselves or as part of a district: Big Piney Culvert (Taxi Stand), Big Piney Culvert and Ditch, stonework at the three cemeteries, the Amphitheater, and Garlington House." In subsequent sections, however, the report states that "if an historic district comprised of stonework built by German Prisoners of War is considered, these stoneworks would contribute to that district." The report also states that "the Garlington House is appropriate for the National Register...based on the special cultural contribution of the German prisoner of war stonework."14 These contradictory recommendations must be made consistent in any future evaluations of eligibility. In addition, the HPP still lacks an overall historic context for these resources, and does not provide a compelling determination of significance for the stonework or why it may be potentially eligible for nomination to the National Register.

This current evaluation recommends that the stonework at Fort Leonard Wood be assessed in a more comprehensive, holistic manner. This means that specific stonework would not be classified as major or minor, but rather as contributing or not contributing. Using the information previously established by the Harland Bartholomew reports in combination with additional contextual information as defined in National Register Bulletin 15, the stone features relating to buildings and sites would be considered collectively as part of a thematic grouping within a historic district.

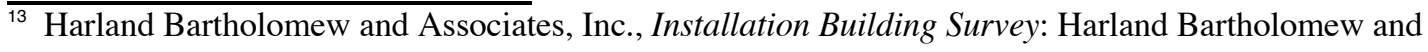
Associates, Inc., Historic Preservation Plan.

${ }^{14}$ Harland Bartholomew and Associates, Inc., HPP, pp. 64-67.
} 
The Harland Bartholomew reports do provide multiple possibilities as to why the extant stone features may be considered significant. Included in this list are:

\begin{abstract}
Association with German POWs
World War II-era dates of construction

The special "cultural contribution" of the stonework

Rarity due to the special artistic value and unique design characteristics

The presence of the stonework as the key defining historic characteristic of

Fort Leonard Wood
\end{abstract}

All of these are valid and important reasons for the significance of the stonework features and need further examination in any future nomination.

Association With German POWs The Army's prisoner of war work program was generally considered a success, for several reasons. It provided widespread manpower to a severely depleted military and civilian labor pool; it was an effective means to manage and control enemy captives harbored in this country; and the War Department also received needed capital from the contracted labor. ${ }^{15}$ The majority of this work did not produce long-lasting, tangible results; rather, the outcome of the work was somewhat ephemeral in nature. For the most part, the nation was left with scattered records, photographs, books, journal articles, and oral histories regarding the POW work experience. Fortunately, there were certain types of work projects that produced more permanent, long-lasting products. The stonework construction at Fort Leonard Wood is an excellent example. The WWII POW experience is an area of American history that is often neglected. Men from Rommel's Afrika Corps were transported to middle America, and although highly trained soldiers, seem to have integrated very peacefully with the local population. The stonework at Fort Leonard Wood is a physical reminder of this experience and needs protection for that reason.

World War II-era Dates of Construction. Historical research has confirmed that these stone features are directly associated with the labor provided by POWs. Admittedly, some of the stonework was performed by U.S. Army labor and some effort needs to be made concerning which are POW efforts and which are Army efforts. However, the Army effort is seen as minimal, and consisting of some repair work to the original POW construction.

The Special "Cultural Contribution" of the Stonework, The presence of the stonework as the key defining historic characteristic of Fort Leonard Wood. German stonemasons provided the expertise to construct the stonework at Fort Leonard Wood. We can assume their skills and their style was learned in Germany prior to the war and this was transferred to the post through their stonework. The various patterns used: Coursed Squared, Random Squared, Course Handcut, Random

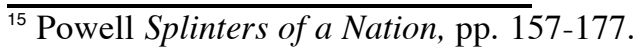


Handcut and Mosaic, may have old world connections and this area of research needs to be explored. Whether or not this is a "key" element in defining the historic characteristic of Fort Leonard Wood needs to be evaluated further. In any case, the stonework does have an artistic quality that lends a distinctive character to the post cantonment that makes it unique.

Rarity Due to the Special Artistic Value and Unique Design Characteristics. One question that was approached in this summary effort was the examination of the rarity of Fort Leonard Wood's POW stonework. To accomplish this, installations where German POWs were incarcerated during the war and that are still currently active were contacted. Following is a list of those installations and the response that was acquired:

Fort Benning, GA.: Public Affairs Office; Several attempts were made to contact Dr. White, base historian, to no avail.

Fort Bliss, TX.: Contacted Cultural Resource Manager, Vicki Hamilton, and historic landscape architect, Larry Schroeder. They report no knowledge or record of stone construction performed by German POWs at Fort Bliss.

Fort Bragg, NC.: Contacted Corps Historian, Cynthia Hayden, Post Archeologist, Beverly Boyko, and Cultural Resource Manager, Bill Kern. None of them are aware of any stone construction by POWs at Fort Bragg. They know that a great deal of landscape work was done, and several concrete culverts and sidewalks were built. In addition, the POWs were contracted out to civilian individuals for a range of agricultural and road maintenance work projects, typical of the time.

Fort Campbell, KY.: Contacted historian Lt. Oliphant. He had no knowledge of any POW construction there. Left a message with Larry Martin, strategic planning, but no return.

Fort Carson, CO.: Contacted Scott Hamerick, Museum Specialist, and Steve Chomko, Archeologist. No knowledge of any stone construction by POWs.

Fort Dix, NJ.: Contacted Museum Specialist, Dr. Zimmerman, who said that there were German POWs on post, but they were involved in off-base agricultural, hospital, and cannery work only.

Fort Eustis, VA.: Contacted Museum Specialist, Barbara Bower, Command Historian, Ben King, and Dick Ivey, who is with the Fort Eustis Historical 
and Archeological Association. None have any knowledge of any POW stonework at the fort.

Fort Gordon, GA.: Contacted historian Dr. Carol Stokes. She is aware that POWs were there and were employed on various work details, but they were not involved in construction efforts on post.

Fort Greeley, CO.: No contact

Fort Hood, TX.: Contacted Corps Historian, Dr. Moore, and Archeologist Dr. Kimball. POWs were incarcerated at a camp north of the Main Post. Most of the structures from that time are now gone, and there are no records or examples of stone structures there.

Fort Jackson, SC.: Contacted the Post Museum. They are aware of POWs engaged in agricultural work such as cotton and peanut harvesting, but no record of stone construction work.

Fort Knox, KY.: Contacted Dr. Cameron, historian, and Pam Shinian, staff archeologist. There was a fair amount of stonework constructed on the post, including indoor and outdoor fireplaces, retaining walls, and edging. Apparently the source of the stone was a quarry along a nearby river. It was completed during the 1930s by a combination of PWA, WPA, and local prisoner labor; it was all completed prior to the arrival of the WWII POWs. In the mid-1800s, several stone-reinforced bridges were constructed that served as overpasses for a road that was named the LouisvilleNashville Turnpike. After Fort Knox was built during WWI, this road ran through a portion of its boundaries. During their incarceration period, German POW stonemasons performed repairs to the mortar in the bridges. Etchings in the mortar identified those responsible for the work, and this is still very evident today. Currently, the portion of the turnpike that ran through the fort has been converted into a walking trail. This three-mile segment was placed on the National Register in 1996 as an historic transportation corridor, and the bridges, complete with mortar etchings, are an integral part of the nominated resource.

Fort Leavenworth, KS.: Contacted Janet Rey in the Public Affairs Office. This fort held POWs who were scheduled to be executed. Obviously, they were not allowed work activities during their incarceration. 
Fort Lee, VA.: Talked to Mr. Hansen in the U.S. Army Quartermaster Museum. Apparently Fort Lee was one of many camps across Virginia that held POWs during WWII. The type of work they were involved in included food service, laundry work, motor pools, and light construction, but no stonework.

Fort Lewis, WA.: Contacted Mrs. Santos, historian at the post museum, and Alan Archanbault, Museum curator. Apparently German POWs were responsible for the construction of a gate at the entrance of what once was a primary thoroughfare. Now referred to as "Logistics Gate," it is somewhat ignored and forgotten as the road has been fenced off and is no longer used. There were also examples of stonework at various POW branch camps, which unfortunately no longer exist.

Fort McClellan, AL.: According to Mr. Chapman, historian, a stone pedestrian bridge over a creek may have been built by POWs, but after further research he found this not to be the case. Several murals were also done in buildings. Susie Prater in Real Property sent an article from the PAO files that reveals that numerous examples of stonework were constructed by POWs, including stone walls, chimneys, a patio, and drainage ditches. (Mary Beth Reed, Charles E. Cantley, and J.W. Joseph. Fort McClellan: A Popular History, 105. Photocopy reprint from DEH, Fort McClellan, Alabama.) These features no longer exist today.

Fort McCoy, WI.: Contacted Linda in the PA Office and Mary Limp in the post library. They were not aware of any but will check articles in the library's holdings. Japanese prisoners may have worked on road crews off base. Archeologist Del Greek has been contacted and will relay any applicable information.

Fort Meade, MD.: Contacted Public Affairs Office. No record of POW construction efforts.

Fort Polk, LA.: Contacted post museum. POWs involved in many work tasks, primarily agricultural for civilians, but no construction projects.

Fort Riley, KS.: Many stone features are present, but there is no record of their construction by German POWs (they were either built by contractors or post personnel, all previous to WWII). 
Fort Rucker, AL.: Contacted post museum. POWs not involved in construction projects there.

Fort Sam Houston, TX.: Contacted Environmental Manager Dusty Bruns and Museum Curator John Manguso. Apparently German POWS constructed stonework at nearby Camp Bullis (where the prisoners were detained). Remaining structures include: a retaining wall with letters "POW" inscribed, a culvert, a fireplace in the old post $\mathrm{HQ}$, and a few scattered retaining walls and stone walk edging. They have no plan in effect for future protection or maintenance of these features, but expressed interest in hearing how FLW develops a plan.

Fort Sill, OK.: Contacted Towana Spivey in the Fort Sill Museum. Received a letter dated May 26, 1998. They have yet to identify any building construction undertaken by German POWs. Most were recruited for Fort Sill based on a need to maintain the power plant and rebuild electrical motors. The letter mentions that German prisoners were located at camps throughout Oklahoma. They cut timber and cleared much of the basin for Lake Texoma on the Red River/Washita River. T. Spivey has been told of parquet type wooden floors built by Germans in National Guard Armories in Oklahoma. The letter further states that German and Italian POWs are buried at nearby Fort Reno. Additionally, T. Spivey recalls some foundations at Fort Chaffee, Arkansas that may have been build by German POWs.

Fort Stewart, GA.: Contacted Walter Meeks, Museum Curator. Both Italian and German POWs were involved in various landscape-related tasks, but it was the Germans who built an extensive network of concrete and terra cotta-lined drainage ditches throughout the post. These ditches have served their purpose over the intervening years and are in excellent condition today. However, they are not protected in any way, are not part of a district, and could be demolished tomorrow if the command personnel deemed it necessary. Part of the reason for this is that the origins of these ditches are not well known, and among those who are aware, they are not exactly revered, due to their connection to the German POWs.

Pine Bluff Arsenal, AR.: Phyllis Bledsoe, Public Affairs, is checking on this information; waiting for a response. 
Tobyhanna Army Depot, PA.: Still attempting to get through to the Public Affairs Office.

Presidio, Monterey, Ca.: Two people working here are familiar with nearby old Fort Ord, which is closed now but held German POWs during WWII. A Mr. DeVilbiss, historian, thought POWs may have done some construction work, but was not sure. However, Caroline Cantillas, Archivist, who checked records, found that work projects there centered primarily on agricultural work, and definitely not construction.

For the most part, the preceding list only reviews those installations that are still active. It should be noted that there were many camps or other types of military installations that held POWs during the war that are now inactive. It would be difficult to find out if any stonework construction was performed at those places, primarily because most are no longer active, and most of the related resources have been lost. In addition, POWs may have performed this sort of work off base for civilian employers, and it would be extremely difficult to document that information.

However, there can be several determinations made from the responses acquired during this survey. It is obvious that of the installations from which responses were acquired, the majority did not have construction work of this type performed by German POWs. Of the few that did have some type of stonework construction, many of the features have been lost in the intervening years. Of the few installations that did report extant stone features, there are no protective measures in place or any official inventories or documentation available. In comparison, Fort Leonard Wood has an extensive collection of stone features that have been well documented and have been maintained in generally good condition. Thus, it can be concluded that within the known installations currently under Army control, the POW stonework at Fort Leonard Wood is rare.

Integrity. In making any determination of significance, the integrity of the resource is critical. It is known that the stonework at Fort Leonard Wood is in varying stages of repair from poor to excellent. Stone structures in some places have deteriorated or have been poorly repaired. In many areas that have been restored there has been little attempt to match the original mortar and sandstone. Stonework has also been painted and in some cases stolen. However, although the stone features at Fort Leonard Wood have experienced various degrees of alteration since their construction, as a group these elements retain a high level of integrity. Many are in excellent condition.

Furthermore, restoration projects, such as that performed at the Black Officers' Club have demonstrated that repairs to damaged areas are highly successful. In 1994-5 Fort Leonard Wood's Directorate of Public Works sponsored, and the Department of Defense's Legacy Management 


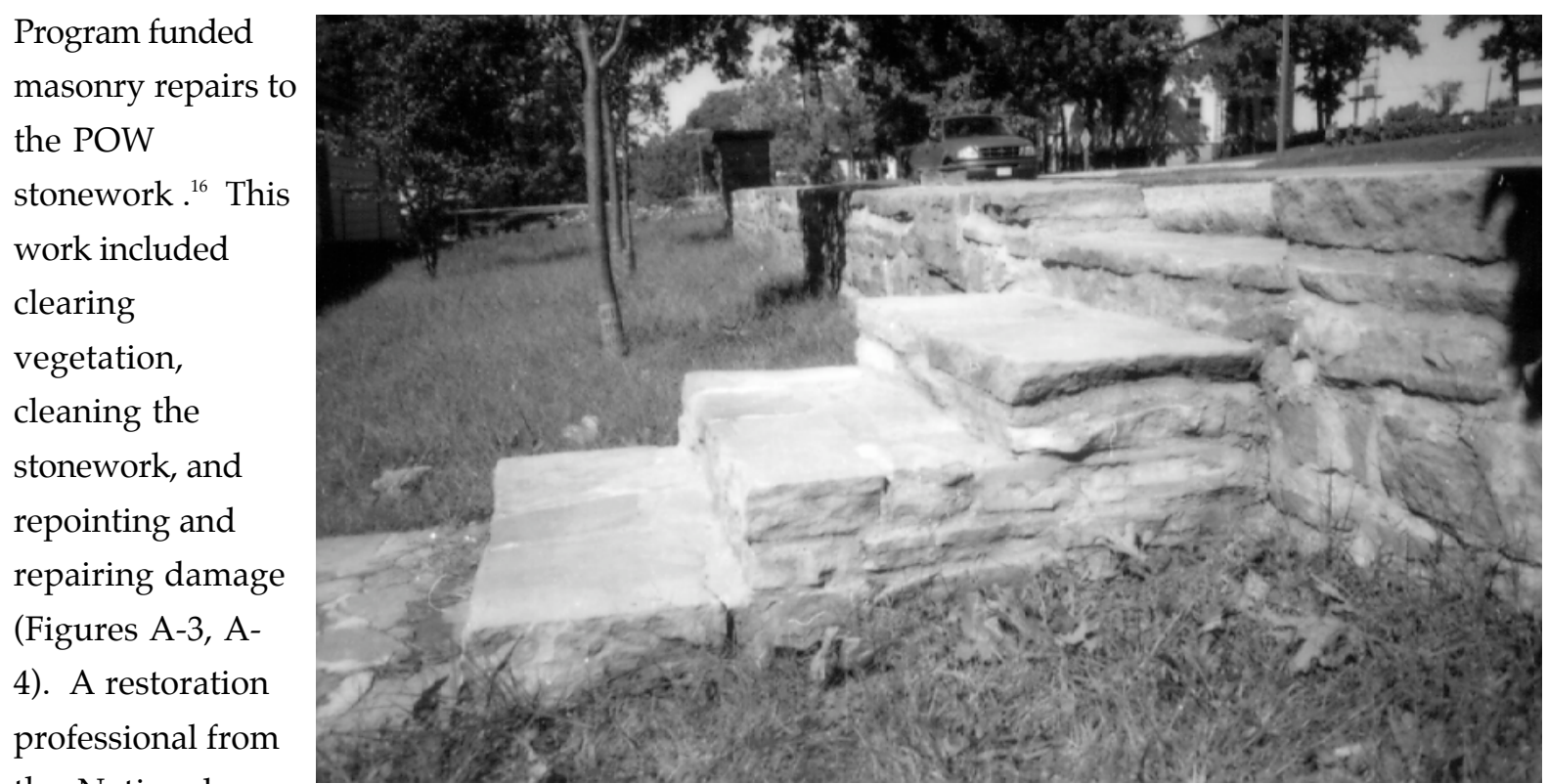

the National

Park Service
Figure A-3 POW Stonework Steps, Building 2101 (SCIAA).

found that the stone originally was laid on a bed of sand, with no bedding mortar, and only the joints were mortared. The mortar used at that time was a "very rich" portland cement, with very course sand aggregate. The mortar was harder than the sandstones used and with freezing and thawing the sandstone broke. The team mixed a similar mortar, but less strong and added lime for plasticity. Broken stones were replaced with stones that had been stored from previous stone work demolition projects.

Areas of stonework deemed eligible in this report are those that have retained a high degree of integrity. Restoration such as successfully performed at the Black Officers' Club will enhance and preserve the resources that contribute to their nomination for inclusion on the National Register.

Eligibility. As a result of the Harland Bartholomew reports and the preceding supplemental information, it can be determined that the stonework at Fort Leonard Wood is historically significant. The stonework represents an association with Fort Leonard Wood's involvement in World War II, and an association with a pattern of events that made a significant contribution to the development of the nation. The stonework also embodies the distinctive characteristics of a method of construction, and their collective presence represents a significant and distinguishable entity whose components may lack individual distinction. Therefore, if an historic district is established at Fort Leonard Wood based on the significant stonework features as part of a thematic nomination, the stonework would be considered eligible for listing on the

\footnotetext{
$\overline{16}$ Douglas C. Hicks, Masonry Repairs To POW Stonework, Black Officers' Club, Fort Leonard Wood, Missouri (National Park Service: Williamsport Preservation Training Center, Harpers Ferry Center, 1995).
} 
National Register of Historic Places under Criterion A: Event, and Criterion C:

Design/Construction.

These stone structures should be included as contributing features to the proposed district (associated architectural elements that may be considered contributing should be determined in a similar manner to this report):

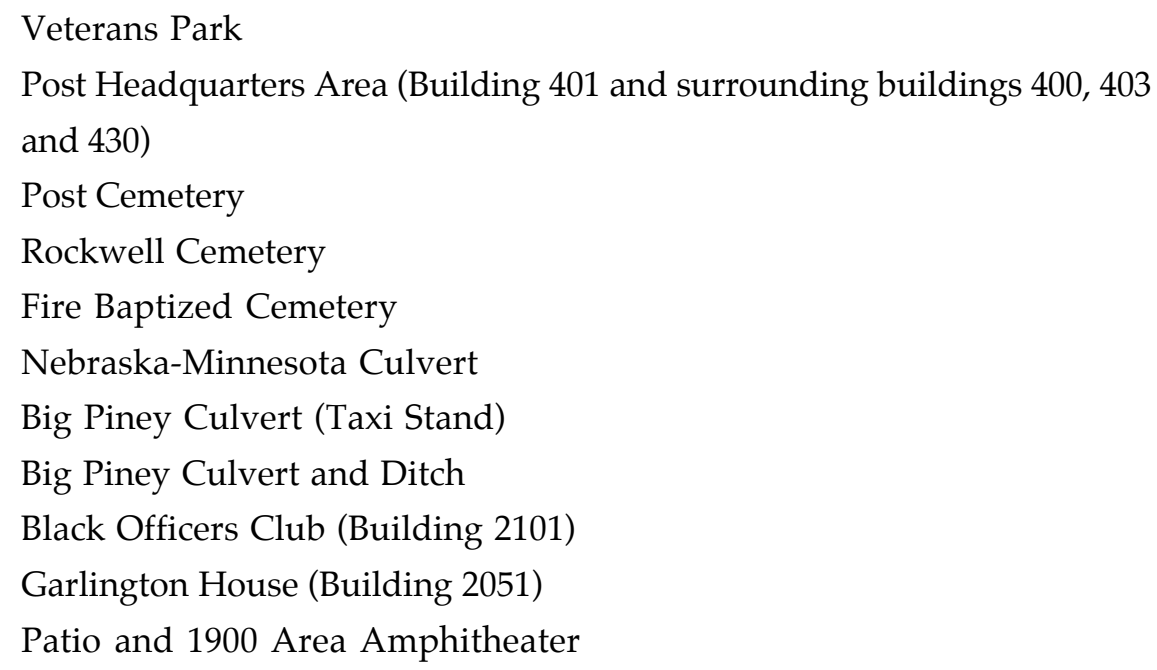

In addition, if any of the "minor stone structures," are judged to adequately convey the significance as determined, and retain adequate integrity, they should also be considered eligible for listing..$^{17}$

It is the further recommendation of this summary that the examples of German POWconstructed stonework that are considered as significant be included as part of a thematic nomination to any proposed historic district. Although many of the examples of stonework may be individually undistinguished, it is the extensive collection of these components that defines the historic character of the cantonment and the potential district. Other historic resources defined as historically significant by the Harland Bartholomew reports could also be included as contributing features to the historic district, under other thematic contexts.

\section{Recommendations for Future Preservation and Maintenance}

Fort Leonard Wood's management of cultural resources is guided by a HPP (1992). An integrated CRM plan as defined in AR200-4 is underway in FY98. The management of historic properties at Fort Leonard Wood like all federal installations, must comply with federal preservation laws as authorized by the National Historic Preservation Act of 1966 as amended, ${ }_{17}$ Harland Bartholomew and Associates, Survey, 1987. 


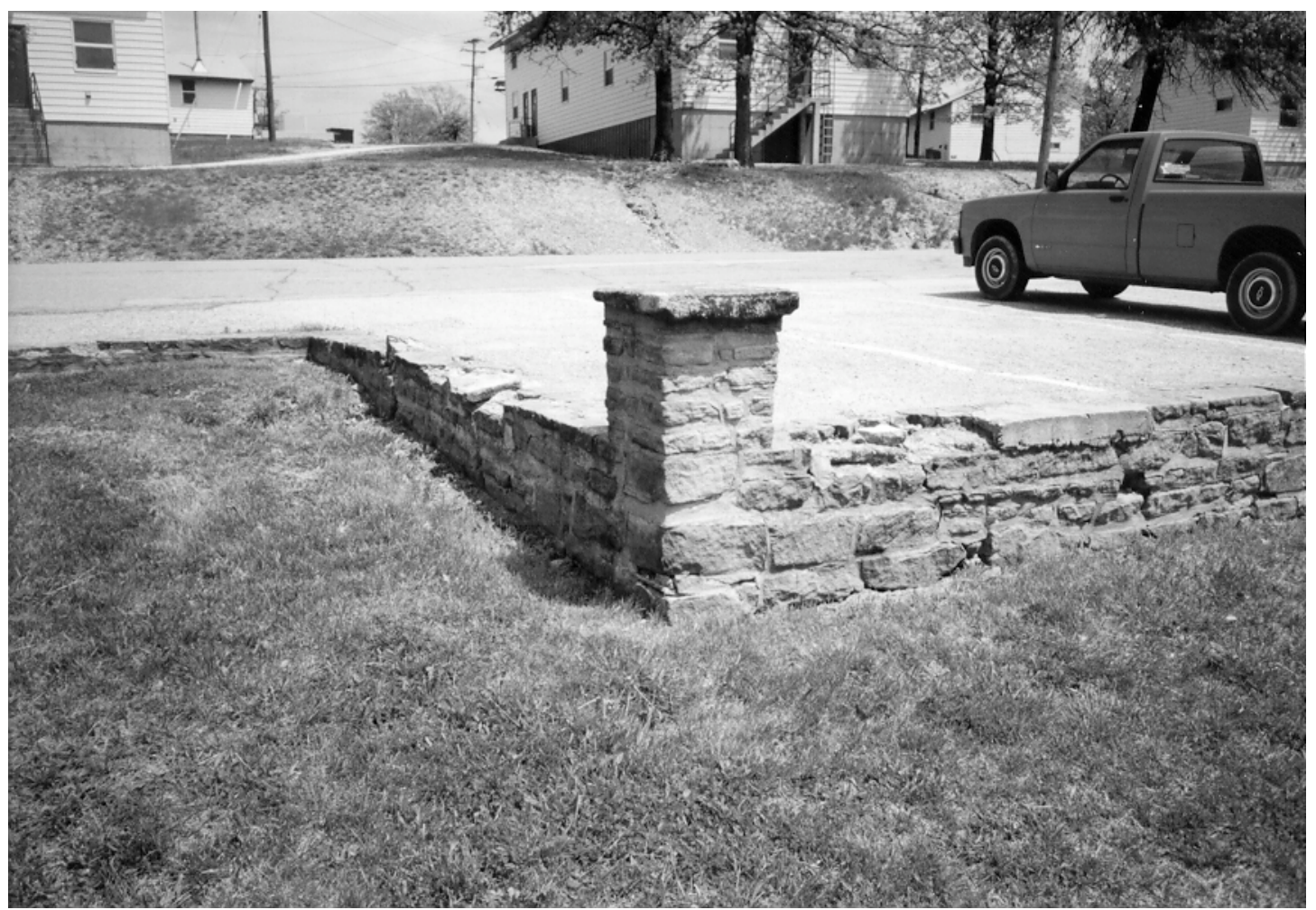

Figure A-4 Corner of Wall in Front of Building 2101 (courtesy, DPW Fort Leonard Wood).

Executive Order 11593 of 1971, and the Archeological Resources Protection Act of 1979 as amended. Section 106 of the National Historic Preservation Act requires that every Federal agency must assess how each of its undertakings could effect historic properties. Section 110 of this act mandates a complete inventory of property along with National Register of Historic Places nomination and protection of eligible properties.

The memorandum of agreement (1986) between the Department of the Army, Headquarters Fort Leonard Wood and the Missouri State Historic Preservation Officer (SHPO) states that activities at the installation must take into account these affects on properties that may be eligible for the National Register of Historic Places. Additional regulations and guidelines used in the standard operating procedure for stonework include: the Secretary of the Interior's Standards and Guidelines for Archaeology and Historic Preservation, and Army Regulation 200-4. Any recommendation made for the future preservation and management of the stonework at Fort Leonard Wood must be guided by these rules, regulations, and agreements. With this in mind, the following recommendations are made for the preservation and maintenance of Fort Leonard Wood's POW stonework resources. 
Recommendation 1: The first step in any management program is to have in place a current inventory of resources. It is recommended that Fort Leonard Wood complete an inventory of all stonework resources on post and update their status. This inventory should build on previous work and can be completed without major time and expense. In essence, the goal is to check the accuracy of previous work and update current conditions.

Recommendation 2: POW stonework at Fort Leonard Wood should be nominated to the National Register of Historic Places as a Historic District. Prior to the preparation of a National Register Nomination, it is imperative that the stone features listed are not in any way damaged, altered, or removed. The completion of the nomination form may determine that some of the stone features are not eligible for listing, but until this has been determined, all stonework should be left undisturbed. These historic resources cannot be replaced if they are destroyed.

A) In preparation of this district, historic data from previous work should be synthesized into a context statement.

B) All contributing elements should be photo-documented if this has not already been accomplished.

Recommendation 3: Until the inventory and nomination process is complete the following operating procedures should be followed:

1. In the future any repair to existing stonework should include mortar and stones that match WWII era stonework in design, color, texture and other visual qualities.

2. Stonework that is associated with WWII era buildings (not slated for demolition) should be maintained and renovated (see below) in order to preserve the stonework and the integrity of the buildings. As long as the buildings perform as working facilities, the stonework should be maintained and preserved. These include: sidewalks, culverts, retaining walls, hydrant walls, and chimneys.

3. Stonework not associated with particular buildings but have a historical context and function should be maintained and preserved. These include cemetery walls, amphitheaters, gardens and culverts.

4. Stonework not associated with a particular building but still functioning as drainage etc., should be maintained as historical features. These include drainage ditches, culverts, retaining walls, and sidewalks.

5. Stonework that loses its context and function in association with a building should be removed only after consultation with the Directorate of Public Works Environmental Division's Cultural Resources Manager. Current TRADOC policy concerning WWII Temporary wood buildings 
instructs installations to remove excess and obsolete buildings not required to support the Army's mission. Some temporary buildings will be maintained to support existing and foreseeable missions.

6. Since TRADOC policy does not include a consideration of historic WWII era stonework this document and the HPP (1992) should serve as a preliminary preservation standard operating procedure for stonework across Fort Leonard Wood. As part of the final report on the rehabilitation of the Black Officers' Club a formal preservation plan should be developed. This plan should be a detailed standard for rehabilitating stonework across the installation.

Recommendation 4: Documentation and synthesis statements concerning the POW stonework generated by the inventory and nomination process should be included in the Integrated Cultural Resources Management Plan. Periodically, the installation will have to update the ICRMP. It will be important to include any new information and management programs developed for the preservation and management of the stonework.

Recommendation 5: The stonework restoration work at the Black Officers' Club was very successful. All examples of stonework that are determined to be contributing elements in the nomination of this stonework to the National Register should be repaired or restored, and conserved as appropriate. An on-going line project within the installation's cultural compliance program funding should be provided for this work until all contributing elements have been restored. Although specific treatments will depend on the condition and extent of each individual contributing element, the following programs should guide treatment programs:

Secretary of the Interior's Standards and Guidelines: Standards for Historic Preservation Projects.

Guidelines for the Treatment of Historic Landscapes. Preservation Assistance Division, National Park Service, 1992.

(Draft) Preservation Brief \#1: The Cleaning and Waterproofing Coating of Masonry Buildings. National Park Service, 1975.

Preservation Brief \#2: Repointing Mortar Joints in Historic Brick

Buildings. National Park Service, 1980.

Cleaning and Surface Repair: Past Mistakes and Future Prospects," John

Ashurst. Association for Preservation Technology, XVII, no. 2, 1985. 
Moisture Problems in Historic Masonry Walls: Diagnosis and Treatment.

Baird M. Smith, National Park Service, 1979.

A Glossary of Historic Masonry Deterioration Problems and Preservation Treatments. Compiled by Anne E. Grimmer, National Park Service, 1984. Masonry Repairs to POW Stonework: Black Officer's Club," Douglas C. Hicks, Williamsport Preservation Training Center, National Park Service, FY 1995.

The latter document in particular should be closely reviewed for any future maintenance of stonework at Fort Leonard Wood.

Recommendation 6: The on-going environmental compliance review program for prehistoric and historic cultural resources should include the review of any proposed ground disturbing activities on post which would affect or endanger the physical context of stonework contributing elements. Any proposed modification of these stonework should be approved by the Directorate of Public Work's cultural resources manager. This review should be integrated into the overall base environmental program.

Recommendation 7: An inventory and assessment of POW stonework conditions should be conducted on a 3 to 5 year basis by the installation cultural resource manager. Any deterioration or alteration should be noted and steps taken to restore or repair damages.

Recommendation 8: An interpretive program, including signs, should be adopted by the installation identifying to visitors the POW stonework and its historic importance. This program should be integrated with the U.S Army Engineer Museum's POW display. 